LEANDRO KEY HIGUCHI YANAZE

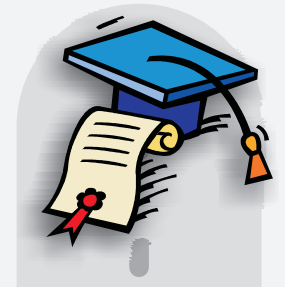

\title{
TECNO-PEDAGOGIA: OS ASPECTOS LÚDICOS E PEDAGÓGICOS DA COMUNICAÇÃO DIGITAL
}

\author{
UNIVERSIDADE DE SÃO PAULO \\ ESCOLA DE COMUNICAÇÕES E ARTES
}

\section{SÃO PAULO 2009}




\section{TECNO-PEDAGOGIA: OS ASPECTOS LÚDICOS E PEDAGÓGICOS DA COMUNICAÇÃO DIGITAL}

Dissertação apresentada ao programa de PósGraduação em Ciências da Comunicação, Área de Concentração Interfaces Sociais da Comunicação da Escola de Comunicações e Artes da Universidade de São Paulo, como exigência parcial para obtenção do Título de Mestre em Ciências da Comunicação, sob a orientação do Prof. Dr. Massimo Di Felice. 


\section{TECNO-PEDAGOGIA: OS ASPECTOS LÚDICOS E PEDAGÓGICOS DA COMUNICAÇÃO DIGITAL}

BANCA EXAMINADORA

SÃO PAULO, DE DE 2009. 


\section{DEDICATÓRIA}

À minha família, onde sempre encontro abrigo, seja entre as memórias e ensinamentos dos que já foram descansar, seja entre cada encontro especial com aqueles a quem amo muito.

Destaco os meus pais, Mitsuru e Luri, e a minha querida irmã caçula, Juliana e o meu futuro cunhado Gusha (que agüenta ela).

À minha futura família, em fase de planejamento e construção em conjunto com a Mitie, a mulher a quem amo e quero dedicar a minha vida. 


\section{AGRADECIMENTOS}

Ao Prof. Dr. Massimo Di Felice que, mais do que orientador, professor e consultor dos mais diversos assuntos que se possa imaginar, foi e é um amigo muito precioso e está guardado eternamente dentre os mais queridos, sendo um exemplo único de dedicação à pesquisa.

Aos Profs. Drs. Lúcia Santaella e Gilbertto Prado pela valiosa contribuição no exame de qualificação e por suas biografias e obras bibliográficas que ressaltam a importância da pesquisa interdisciplinar da comunicação digital.

Ao Centro de Pesquisa ATOPOS (ECA/USP) pela dedicação e empenho em investigar os impactos das tecnologias digitais de comunicação por meio de pesquisas de alto nível e em permanente diálogo com outros centros de pesquisa ao redor do globo. Em especial a todos os pesquisadores/colegas/amigos do grupo, que sempre incentivaram e demonstraram um carinho incondicional em todas as etapas desta pesquisa.

Ao Prof. Dr. Derrick De Kerckhove por sua obra de inestimável valor para abordar os aspectos teóricos da comunicação digital e pelas horas despendidas entre passeios, jantares e encontros acadêmicos nas quais carinhosamente autorizou o desenvolvimento do termo da tecnopsicologia de sua autoria, e da qual se deriva o conceito-chave desta dissertação.

À minha querida família pela compreensão nos momentos de estresse e desligamento total para me concentrar na pesquisa. Aos meus pais como exemplo de excelência e dedicação na vida profissional, acadêmica e, principalmente, no exemplo de vida e de fé.

À minha futura esposa Mitie, que me apoiou e ajudou de diversas formas, compreendendo os momentos de dedicação para esta dissertação sempre me incentivando.

E Àquele que, criador e criativo, nos concedeu a vida, a inteligência e a alegria de dar cada passo da nossa jornada.

Muito obrigado. 


\section{RESUMO}

Esta pesquisa se insere nas linhas de investigação do Centro de Pesquisa ATOPOS, da Escola de Comunicação e Artes da Universidade de São Paulo (ECA/USP) sobre os aspectos teóricos das mídias digitais. Explora a interdisciplinaridade da comunicação digital, ressaltando os aspectos lúdicos e pedagógicos presentes na relação dialógica entre o homem e a tecnologia. Para tanto, desenvolve-se a discussão teórica de vários autores que tratam sobre tecnologia, comunicação digital, ludicidade e pedagogia. Contextualiza-se o universo dos videogames descrevendo as diversas gerações, plataformas e interações promovidas pelos diferentes gêneros de jogos. Por fim, é realizada a análise de alguns jogos como forma de sustentar o conceito de "tecno-pedagogia" proposto por este trabalho.

Palavras-chave: Comunicação digital. Ludicidade. Pedagogia. Videogame. Tecnologia. Tecno-pedagogia.

Observação: Esta dissertação é acompanhada de um CD-ROM contendo a sua versão eletrônica e materiais de referências utilizados durante a pesquisa. 


\begin{abstract}
This research falls within the lines of investigation of the Research Center ATOPOS, from the School of Communication and Arts of the University of Sao Paulo (ECA / USP) on the theoretical aspects of digital media. It explores the interdisciplinarity of digital communication, highlighting the entertainment and educational aspects in the dialogical relationship between man and technology. To this end, it develops a theoretical discussion of several authors who deal on technology, digital communication, leisure and education. It contexts the universe of videogames describing the different generations, platforms and interactions promoted by different genres of games. Finally, it performs the analysis of some games as a way to sustain the concept of "techno-pedagogy" proposed by this work.
\end{abstract}

Key-words: Digital communication. Playfulness. Pedagogy. Videogame. Technology. Techno-pedagogy. 


\section{SUMÁRIO}

INTRODUÇÃO

Tema. 11

Problema

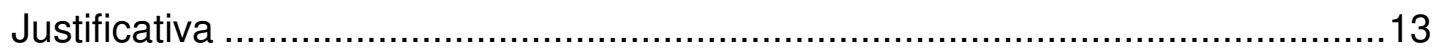

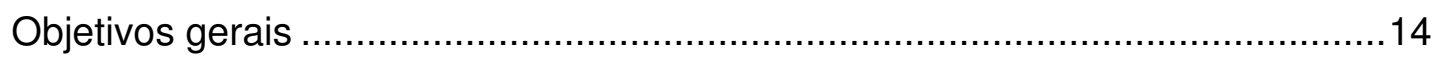

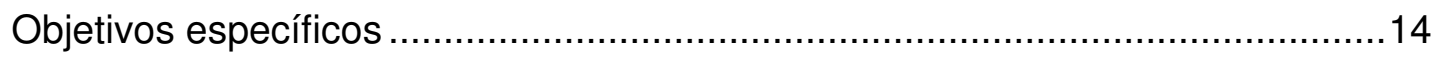

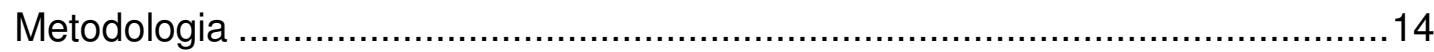

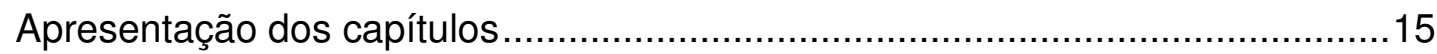

CAPÍTULO 1 - Diálogos entre o homem e a técnica...............................17

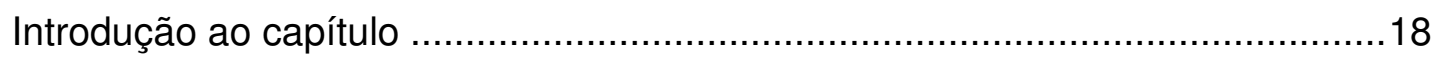

1.1 - A técnica e tecnologia na formação do homem .......................................19

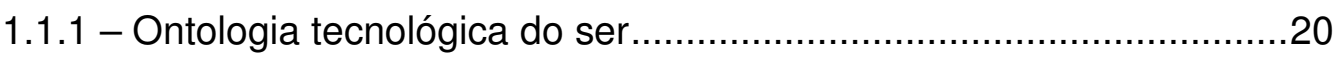

1.1.2 - Uma consideração não instrumental da conjunção homem e

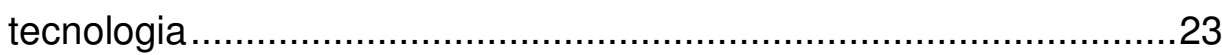

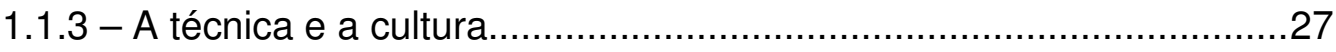

1.1.4 - A técnica como meio e fim na formação do homem .........................29

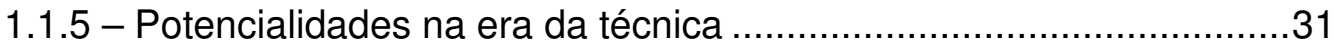

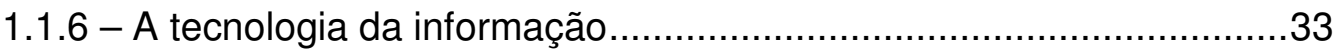

1.2 - Contexto tecnológico midiático na contemporaneidade ...............................34

1.2.1 - Comunicação e interação no ciberespaço formando a inteligência

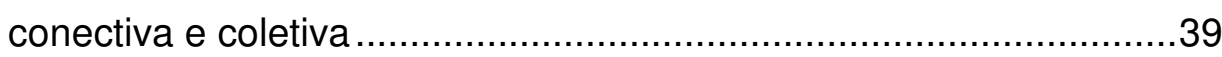

1.2.2 - Produção da informação no ciberespaço .........................................46

CAPÍTULO 2 - Tecno-pedagogia: a formação lúdica do homem tecnológico 51

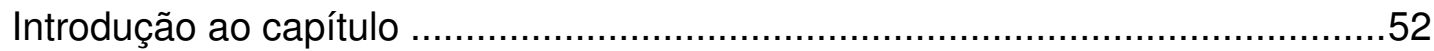

2.1 - Do teatro grego: um partido clássico para uma nova abordagem sobre a formação pelo lúdico e tecnológico....................................................53

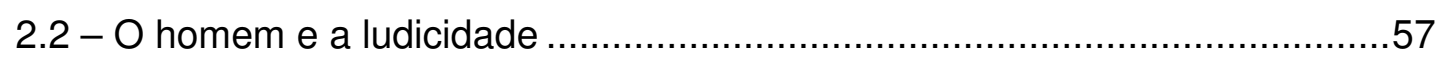

2.3 - A ludicidade como contexto de formação do homem..................................62

2.4 - Brincando etimologicamente da pedagogia até a tecnopedagogia..............69 
2.5 - Tecno-pedagogias: o lúdico e o pedagógico no contexto tecnológico digital .74

2.6 - A mudança de valores da sociedade em rede com a ética dos hackers.....77

\section{CAPÍTULO 3 - Os games (jogos eletrônicos) como tecno-pedagogia 83}

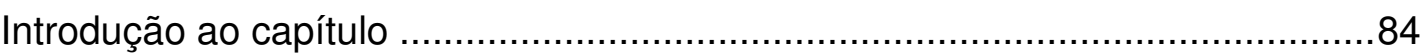

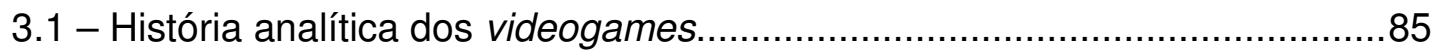

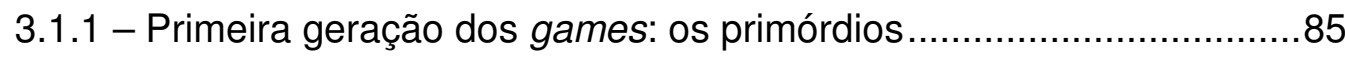

3.1.2 - Segunda geração dos games: os consoles programáveis................90

3.1.3 - Terceira geração dos games: entre computadores e brinquedos ....93

3.1.4 - Quarta geração dos games: consolidação dos videogames.............97

3.1.5 - Quinta geração dos games: tecnologia para o lúdico .....................103

3.1.6 - Sexta geração dos games: tecnologia do lúdico como carro chefe106

3.1.7 - Sétima geração dos games: novos apontamentos ........................112

3.1.8 - Considerações específicas sobre os jogos para computador ........119

3.1.9 - Algumas tendências para as próximas gerações dos videogames 123 3.2 - Aspectos econômicos (mercado e comportamento de consumo) dos games

3.2.1 - O mercado mundial em ascensão dos games ...............................126

3.2.2 - Comportamento do mercado consumidor de games .....................129

3.2.3 - Produção de games no Brasil ......................................................131

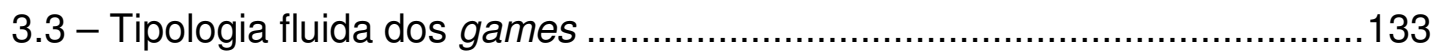

3.3.1 - Abordagem geral dos jogos …….............................................133

3.3.2 - Abordagem específica dos games............................................136

CAPÍTULO 4 - Análise prática: estudo de games................................139

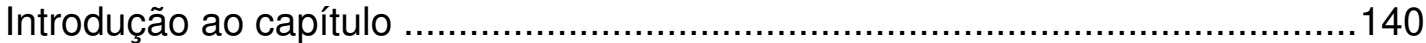

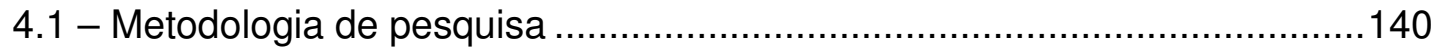

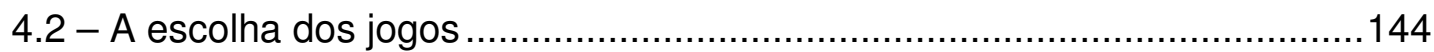

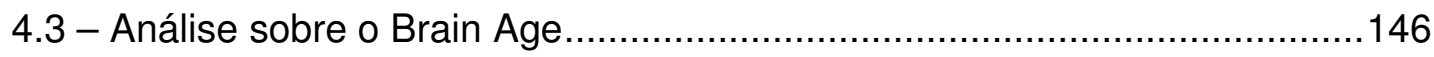

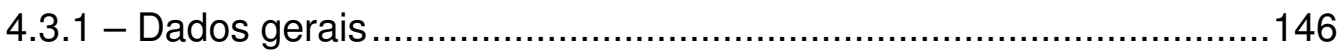

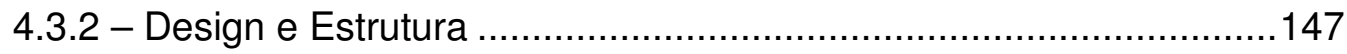

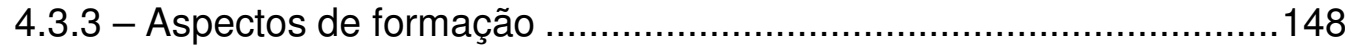

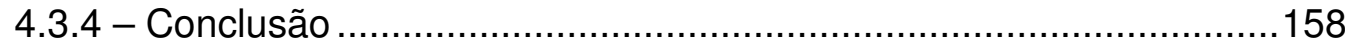




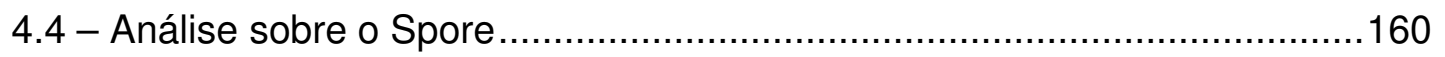

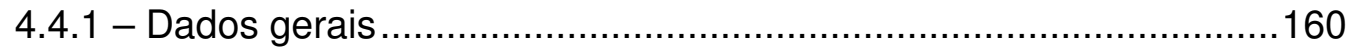

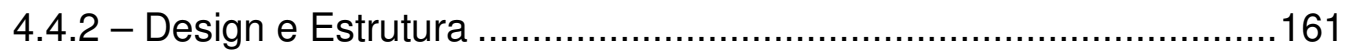

4.4.3 - Aspectos de formação ……………………............................162

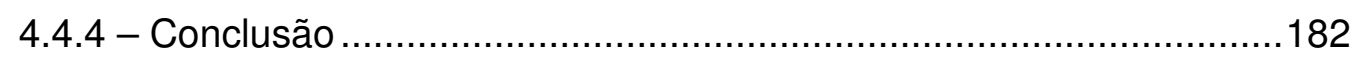

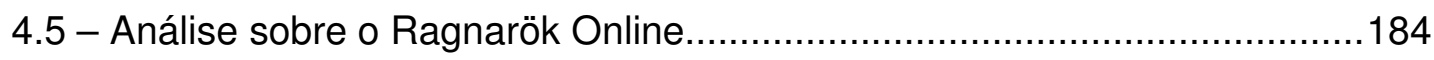

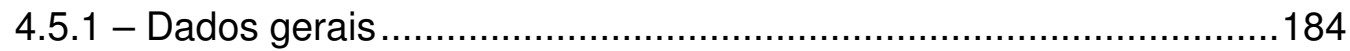

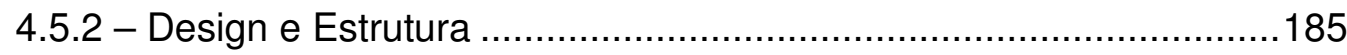

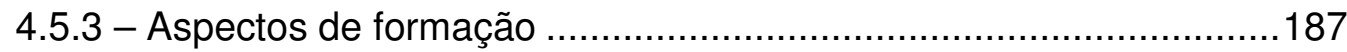

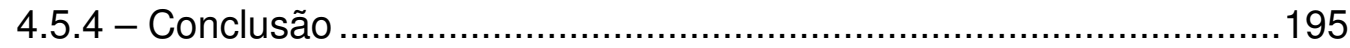

4.6 - Análise sobre o Cozinheiro das Almas..................................................197

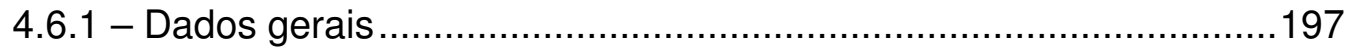

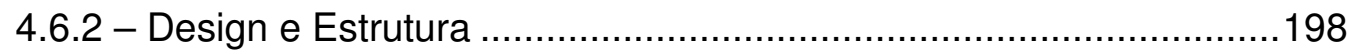

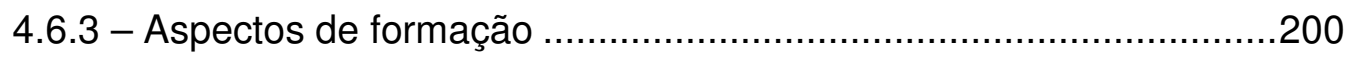

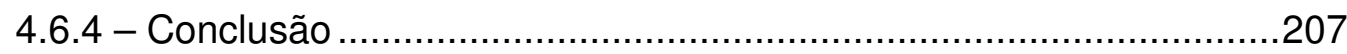

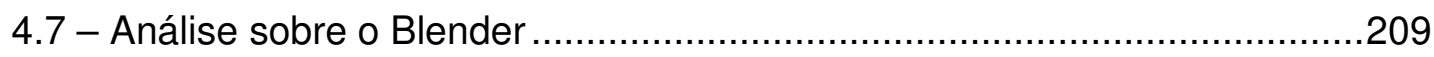

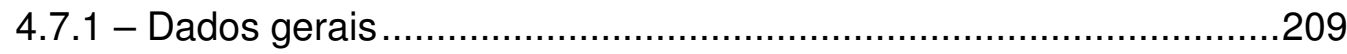

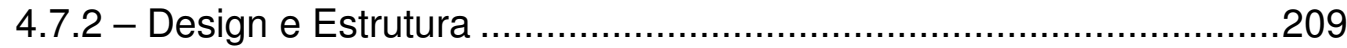

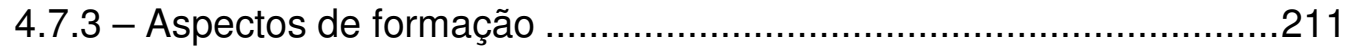

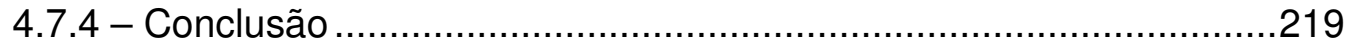

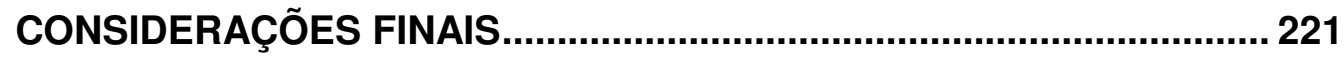

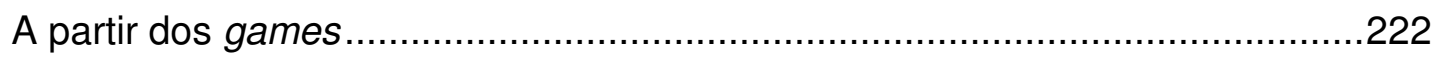

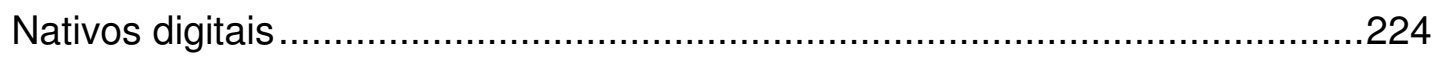

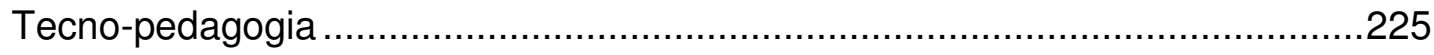

BIBLIOGRAFIA 


\section{INTRODUÇÃO}

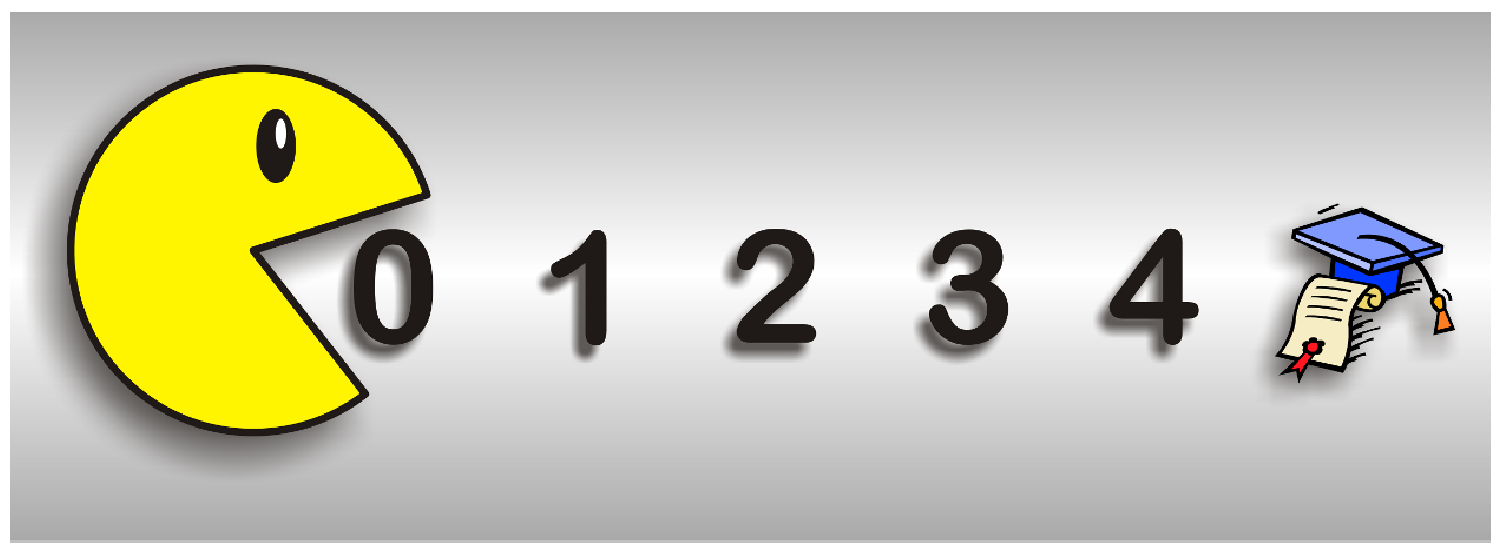




\section{Introdução}

\section{Tema}

No contexto atual, as tecnologias digitais deixaram de ser exclusivamente partes do "fazer" (da produção, engenharia, etc.) para alcançar a esfera da percepção e do conhecimento. Tal apontamento pode ser exemplificado pelo fato das transações econômicas, a busca de informações gerais na rede, até mesmo as formas de entretenimento, estarem atreladas a ações permeadas pelas tecnologias digitais.

Ao possibilitar a mudança nos estilos de vida das pessoas, a tecnologia digital entra também no interior da estrutura mental da percepção e do conhecimento, alterando-a profundamente, assim como aconteceu com a escrita e, depois com a mídia de massa. Este elemento torna-se ainda mais relevante se observado entre as novas gerações - os "nativos digitais"...

Sobre os nativos digitais, uma das principais atividades de destaque estão os jogos eletrônicos, ou videogames, onde se encontra uma farta oferta de entretenimento digital que fascina pela qualidade gráfica, pelo desafio do reflexo, pela interatividade e pela ficção que constrói e oferece novos universos virtuais. Os videogames, ícones do entretenimento digital, se tornam objetos de consumo e desejo tanto para o público infantil, quanto para jovens e adultos (que, em sua infância, conviveram com os primeiros modelos de entretenimento eletrônico).

Essa oferta acontece, majoritariamente, explorando os aspectos comerciais do fascínio que a ludicidade digital provoca no público consumidor. Existem algumas expressivas iniciativas de produzir jogos eletrônicos voltados para a educação. Fazse necessário, então, aproximar o contexto tecnológico com a produção lúdica e com processos pedagógicos na era digital, buscando compreender a sociedade informacional sob o aspecto de seu desenvolvimento. Para tanto, crê-se necessário analisar exemplos de jogos eletrônicos, identificando os pontos de valor pedagógico.

Para agir na esfera do lúdico e do pedagógico, os games são um convite para uma nova forma de compreender o dinamismo transorgânico que se estabelece na relação entre o homem e a tecnologia. Nesse sentido, faz-se necessário considerar que a relação homem-tecnologia não é determinada por uma lógica instrumental, 
onde, de forma dialética, o ser humano utiliza os meios tecnológicos para construir, destruir, modificar, descobrir, aprender e brincar. A relação homem-tecnologia exige a consideração de uma concepção dialógica onde o homem desenvolve a tecnologia e é desenvolvido por ela.

Os games são produzidos seguindo uma perspectiva mercadológica que explora os recursos multimidiáticos na indústria do espetáculo tecnológico. Mas os games, como toda tecnologia, transforma o ser humano, seja nos reflexos neurais ou na velocidade de raciocínio, seja nos valores morais ou nas concepções de sociabilidade. Dessa forma, o universo dos games, assim como toda a tecnologia digital, não pode ser considerado como simples resultado da indústria do entretenimento, mas deve ser considerado, em seus valores pedagógicos benéficos e maléficos, como tecnologia que interage e que transforma o ser humano.

\section{Problema}

O homem vai além da constituição orgânica quando, em interação e integração com a tecnologia, passa a sobreviver, viver e conviver de forma transorgânica (desde a necessidade das vestes até o uso do computador como mediador das suas ações comunicativas). É impossível considerar o homem atual sem a tecnologia que define a sua formação.

Ao analisar aspectos da contemporaneidade, no caso, o impacto das tecnologias digitais na sociedade, surgem muitas dúvidas e questionamentos. Quando se trata da ludicidade digital, tantas outras dúvidas surgem, pois parece não haver nenhum tipo de ganho social. Muito se fala sobre a violência e insinuações ilícitas às drogas, pornografia e o incentivo ao isolamento social e ao sedentarismo.

Mas também seria importante considerar que, mais que o conteúdo e as possíveis influências negativas sobre o comportamento das novas gerações, os games convidam para outras arquiteturas informativas e perceptivas, caracterizando, de forma técnica e interativa, a experiência do conhecer e do interagir.

É possível prever qual a real influência do entretenimento digital no cotidiano e nas relações entre as pessoas? Tais questões se ampliam e desafiam o próprio sentido da tecnologia produzida e que modifica o comportamento humano. 


\section{Justificativa}

Ao tentar responder aos questionamento levantados, esta pesquisa se responsabiliza em auxiliar na compreensão da relação dialógica entre homem e tecnologia, mostrando que essa sinergia promove a educação de forma lúdica. Nesse sentido, uma análise mais profunda sobre as críticas levantadas em razão à aceitação social imediata e crescente das tecnologias digitais de comunicação, exemplificadas nos videogames, se faz necessária e poderá auxiliar na compreensão dos potenciais reais da influência do entretenimento digital na formação social. Dessa forma, o presente estudo pode vir a auxiliar pais e educadores a desenvolver uma postura equilibrada sobre os jogos eletrônicos na interface com as crianças e jovens.

No meio acadêmico, os games só podem ser estudados por um viés transdisciplinar porque remete a um conjunto de transformações perceptivas, sensorias, interpretativas, cognitivas e qualitativas. Isto faz do game algo muito mais do que um simples instrumento lúdico de entretenimento que merece a atenção da análise acadêmica. De fato, as ciências da comunicação pedem uma percepção transdisciplinar (comunicativa, tecnológica, pedagógica, filosófica, psíquica etc.) e isso, sobretudo sobre as tecnologias comunicativas digitais.

Esta pesquisa contribui ao desenvolver uma temática atual, que emprega autores e obras que tratam sobre a contemporaneidade. O estudo sobre a comunicação nunca será completa se os aspectos das tecnologias digitais não forem considerados. Os jogos eletrônicos, nesse sentido, devem ser enfocados de forma madura, não só pela sua relevância econômica, mas pelo potencial comunicativo e interativo que tal plataforma oferece. Faz-se necessário abordar os jogos eletrônicos de forma transdiciplinar, passando pelos campos teóricos da comunicação, da tecnologia digital e da pedagogia.

Para o pesquisador, o interesse pessoal em realizar tal pesquisa se dá pelo enfoque na tecnologia aplicada e sua importância social. Não existe a dualidade entre um caráter integrado ou apocalíptico, como descreveu Umberto Eco ${ }^{1}$. Mas a intenção da pesquisa é desenvolver, de forma madura e consistente, uma análise sobre a atualidade tecnológica, comunicativa e comportamental, em seus aspectos lúdicos e pedagógicos. 


\section{Objetivos gerais}

Esta pesquisa propõe compreender a relação entre o homem e a tecnologia, considerando que existe uma construção mútua onde o homem constrói a tecnologia e é por ela construído; assim, propõe identificar os significados das resultantes pedagógicas e lúdicas dessa relação; desenvolver uma visão analítica sobre os jogos eletrônicos como produto digital, lúdico e pedagógico e analisar os aspectos educativos dos videogames.

\section{Objetivos específicos}

Para alcançar os objetivos gerais da pesquisa, optou-se por:

- Fazer uma revisão bibliográfica para construir uma base teórica sólida sobre o papel da tecnologia na existência humana;

- Aprofundar nas questões relativas aos significados das interações entre sujeito e tecnologia comunicativa;

- Analisar a discussão filosófica sobre o conceito de técnica no pensamento contemporâneo;

- Compreender os significados das interatividades possibilitadas pela ludicidade transorgânica (relação homem-tecnologia), exemplificada pelos videogames;

- Analisar o universo dos videogames, compreendendo os aspectos tecnológicos e os impactos no comportamento de consumo e social;

- Analisar alguns jogos eletrônicos, identificando os pontos possíveis de contribuição pedagógica na formação do indivíduo e da sociedade;

\section{Metodologia}

A metodologia da pesquisa se divide em dois níveis:

1) Desenvolvimento teórico

A revisão bibliográfica permitiu "costurar" pontes teóricas entre autores que, relacionando comunicação e educação, sustentam a base da pesquisa. Autores que tratam sobre a tecnologia, como Martin Heidegger, Umberto Galimberti, Marshall

\footnotetext{
${ }^{1}$ ECO, Umberto. Apocalípticos e integrados. São Paulo: Perspectiva, 2006.
} 
McLuhan e Lúcia Santaella, auxiliaram na compreensão sobre o conceito de tecnologia e as implicações sociais de tais conceitos.

Manuel Castells, Pierre Lévy, Derrick De Kerckhove, Lúcia Santaella, Gilbertto Prado e Massimo Di Felice auxiliaram na desconstrução dos conceitos da comunicação tradicional, permitindo construir um olhar mais maduro sobre os aspectos teóricos que permeiam a comunicação digital.

Johan Huizinga e Marshall McLuhan falam sobre a ludicidade e vários autores na área de educação e pedagogia elaboram as pontes necessárias entre o elemento lúdico e o processo de formação dos indivíduos, conectando os pontos levantados por essa dissertação.

\section{2) Desenvolvimento prático}

Optou-se pela análise sobre a história dos jogos eletrônicos, identificando os aspectos tecnológicos envolvidos e os seus impactos sociais. Em seguida, desenvolveu-se de uma categorização dos diferentes tipos de jogos eletrônicos, classificando-os por tipo e identificando suas principais características de jogabilidade. E, por fim, realizou-se a Análise de jogos eletrônicos de diferentes tipos: Brain Age, Spore, Ragnarök Online, Cozinheiro das Almas e Blender.

\section{Apresentação dos capítulos}

Alguns temas abordados na pesquisa, considerando o fato de se tratar de um assunto contemporâneo e, portanto, muito pouco explorado, não contam com base teórica específica. Assim, essa pesquisa "costura" obras e autores que nem sempre são próximos em seu discurso, mas que atendem a finalidade de oferecer uma base teórica sólida que permita interpretações sobre a contemporaneidade.

O trabalho está dividido em duas partes. A Parte I, constituída por 2 capítulos, refere-se ao desenvolvimento teórico da pesquisa. O Capítulo 1 apresenta a concepção dialógica entre homem e tecnologia que se estabelece no momento em que se compreende que o homem desenvolve e usa as várias técnicas, mas delas depende como parte do seu processo de formação. Para tanto, autores como Galimberti e Heidegger se constituem na base para o desenvolvimento de uma conceituação do diálogo constitutivo transorgânico que existe entre o ser humano e o meio tecnológico. Promove a discussão sobre o contexto das tecnologias digitais 
de comunicação, esboçando os aspectos teóricos da comunicação digital relevantes na discussão das relações reais e virtuais com a informação e a ponte social que se constrói em rede, de maneira interativa. Autores como Pierre Lévy, Di Felice, Santaella, entre outros, formatam a base da discussão sobre as tecnologias comunicativas digitais.

O Capítulo 2 apresenta os aspectos lúdicos inerentes a essa relação entre tecnologia e homem. Apresenta o termo "tecno-psicologia" de Derrick De Kerckhove, diretor do McLuhan Program in Culture and Technology da Universidade de Toronto, como norteador de uma postura dialógica e natural diante da tecnologia, seguindo os passos do seu icônico antecessor acadêmico Marshall McLuhan, e explica a origem do conceito "tecno-pedagogia" título e tema da dissertação.

Já na Parte II, o Capítulo 3 apresenta a produção tecnológica e lúdica dos videogames, aprofundando os pontos históricos e a relação existente entre videogame, entretenimento, indústria cultural e sociedade do consumo do espetáculo. Formata-se, também, uma tipologia de jogos, introduzindo às várias plataformas lúdicas existentes na interação entre homem e computadores.

O Capítulo 4 refere-se à análise e à observação empírica de algumas plataformas de jogos eletrônicos, ressaltando os pontos lúdicos e pedagógicos que compõem o universo dos videogames que dificilmente têm espaço de discussão em meio acadêmico.

Por fim, apresentam-se as considerações finais onde são colocadas as reflexões que concluem a pesquisa a partir da construção teórica em conjunto às análises práticas desenvolvidas na dissertação.

Faz-se necessário notar que, por uma opção assumida em orientação, estão presentes algumas inserções (identificadas pelo fundo cinza, como no exemplo abaixo) onde o pesquisador expressa impressões, lembranças e até ficções que dialogam com o texto em linguagem mais informal e pessoal. Tais inserções se apresentam como resultado direto de um contexto onde a mensagem é cada vez menos linear e cada vez mais "hiperlinkada", multimidiática e multilingüística, características próprias das tecnologias comunicativas digitais. 


\section{CAPÍTULO 1 - Diálogos entre o homem e a técnica}

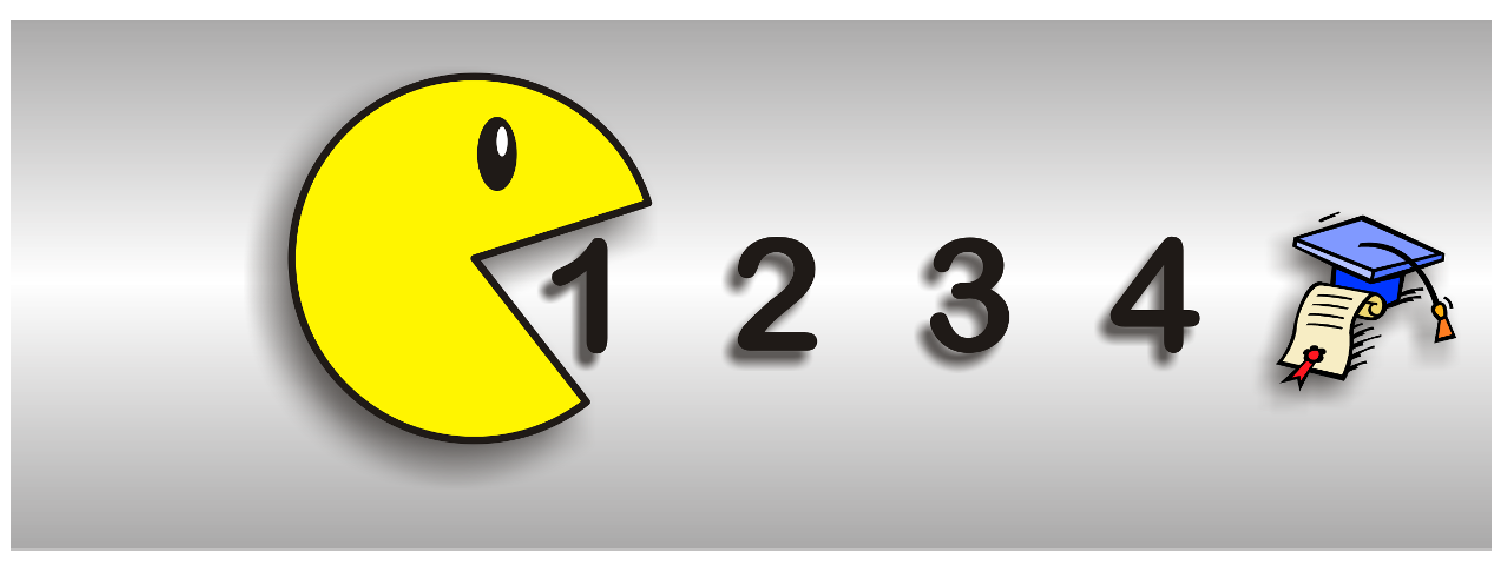




\section{CAPÍTULO 1 - Diálogos entre o homem e a técnica}

\section{Introdução ao capítulo}

Este capítulo que inicia a dissertação pretende apresentar e desenvolver as bases teóricas que fundamentam a pesquisa. Partindo de literaturas que discutem filosoficamente 0 ambiente tecnológico da comunicação na sociedade contemporânea, o capítulo aborda dois principais temas que buscam justificar a pesquisa quanto à sua relevância no campo teórico da comunicação.

Primeiramente, busca-se explorar relação entre o homem e a técnica na sua essência não instrumental. Baseando-se principalmente na discussão sobre a técnica promovida pelas obras de Martin Heidegger, Umberto Galimberti, Marshall McLuhan e Lúcia Santaella, a dissertação assume a concepção de que a tecnologia não só é usada pelo homem, mas uma vez que este a desenvolve, passa a se desenvolver por ela em uma relação dialógica.

Depois, o capítulo desenvolve a contextualização do meio tecnológico da comunicação contemporânea nas concepções de Manuel Castells, Pierre Lévy, Derrick De Kerckhove, Lúcia Santaella e Massimo Di Felice. As definições de ciberespaço e cibercultura que se tornam o cenário do novo habitar humano são descritas como a condição que permite a efetiva e democrática inteligência coletiva e conectiva e que transforma a condição social do homem contemporâneo, ao mesmo tempo que promove a formação de um novo indivíduo conectado.

Dessa forma, pretende-se de apresentar e desenvolver conceitos consagrados e inovadores do campo das comunicações para compreender como os territórios e meta-terrritórios tecno-informativos promovem o surgimento e a formação de um novo homem e, portanto, de uma nova organização social. Por se tratar de um movimento de mudança contemporâneo, o capítulo não pretende definir o novo homem, mas mostrar que a sua formação sempre um diálogo com a técnica existente e que, em plena era da tecnologia digital, é necessário considerar um ser, agora, digital. 


\section{1 - A técnica e tecnologia ${ }^{1}$ na formação do homem}

Ao assistir a obra prima de Stanley Kubrick "2001: Uma odisséia no espaço", lançado nos cinemas em abril de 1968, o hiato temporal e semântico contido entre a famosa cena do osso lançado aos céus pelo primata e a sobreposição da estação espacial em órbita sideral nos leva a refletir sobre o que ocorreu nos quatro milhões de anos que se passaram entre o dia em que os nossos ancestrais se estenderam através de ferramentas ao ponto em que ficamos totalmente simbióticos e dependentes da tecnologia.

O fato é que o homem e toda a sua formação (evolução, história e cultura) estão totalmente atrelados à técnica. As cenas iniciais de Kubrick dão indícios dessa relação ao mostrar que o osso, transformado em ferramenta, permite a caça mais eficiente e permite que o primata tenha outras prioridades além da sua alimentação iminente. Especulando livremente, podemos considerar que, a partir das ferramentas e armas, o primata-homem desenvolve as relações sociais hierárquicas, dando origem às formações tribais e, ao mesmo tempo à preservação da memória e da cultura.

Com a alimentação abundante e a proteção de ajuntamentos sociais, até a fisionomia humana pôde seguir um rumo evolutivo peculiar. O uso de ferramentas auxiliavam em várias atividades penosas e possibilitaram que os nossos ancestrais se eximissem de alguns esforços o que permitiu, conseqüentemente, que o homem assumisse um andar bípede e cada vez mais ereto. Ficando ereto, a caixa craniana pôde crescer permitindo o desenvolvimento cerebral. Mesmo como especulação, é inegável que o homem atual só existe por estar em simbiose com as técnicas e tecnologias.

De fato, a compreensão de boa parte da filosofia ocidental sempre considerou a tecnologia como o conjunto de ações e instrumentos que existem para o interesse do homem, seja como ferramenta de extensão das suas funções corporais e culturais, seja como instrumento de poder e dominação. Mas assim como o osso só

1 Essa dissertação parte da raiz etimológica comum entre técnica e tecnologia usando os dois termos em paralelo mas diferenciando-os onde a técnica é a manifestação de tudo que circunda a existência do homem a partir da ação e transformação de elementos, enquanto a tecnologia é o contexto que 
se torna em ferramenta nas mãos do nosso ancestral, será que o australopithecus teria condições de alçar as linhas evolutivas do homo sapiens sem tais instrumentos, técnicas e tecnologias?

A partir do predicado de Marshall McLuhan, "o meio é a mensagem", faz-se necessário compreender o contexto tecnológico humano (o meio) para descobrir traços do sentido da sua existência (mensagem). Essa investigação só é possível quando se considera que "as conseqüências sociais e pessoais de qualquer meio ou seja, de qualquer uma das extensões de nós mesmos - constituem o resultado do novo estalão introduzido em nossas vidas por uma nova tecnologia ou extensão de nós mesmos." 2

É necessário refletir sobre essa relação inerente entre o homem e a técnica, procurando explorar os vários sentidos de uma construção mútua onde o homem desenvolve a tecnologia e, ao mesmo tempo, se desenvolve por meio dela. Dessa forma, existe uma relação dialógica (diálogo - troca, influência e determinações mútuas) e não dialética entre homem e tecnologia.

\subsection{1 - Ontologia tecnológica do ser}

Partindo do filósofo alemão Martin Heidegger, a relação entre homem e tecnologia desenvolvida nessa dissertação passa a exigir uma consideração que vai além de analisar antropocentricamente como o homem utiliza a tecnologia. É necessário considerar, no entanto, como o homem é, está e está sendo conforme co-existe com a tecnologia.

A este ser/estar, Heidegger denomina de "habitar", sendo que "habitar é o modo como os mortais são e estão sobre a terra" e que "no sentido de habitar, construir desdobra-se em duas acepções: construir, entendido como cultivo e o crescimento e construir no sentido de edificar construções"3 ${ }^{3}$, ou seja, habitar compreende o desenvolvimento e o desenrolar da vida já que "construímos e

reúne todas essas manifestações de forma mais amplar e embarcando as questões culturais envolvidas.

${ }^{2}$ MCLUHAN, Marshall. Os meios de comunicação como extensões do homem. Rio de Janeiro: Cultrix, 1964, p. 21.

${ }^{3}$ HEIDEGGER, Martin. Ensaios e conferências. Petrópolis, RJ: Vozes, 2001, p. 128. 
chegamos a construir à medida que habitamos, ou seja, à medida que somos como aqueles que habitam". 4

Para compreender melhor o "habitar" de Heidegger como ontologia tecnológica do ser, ou seja, o habitar como idéia central que configura a natureza tecnológica do ser, é necessário considerar que não se pode determinar metafisicamente o ser engessando-o em conceitos, mas compreende-se que o homem é, enquanto habita. Dessa forma, Heidegger introduz a sua explicação do habitar (e, em conseqüência, a sua ontologia do ser) e apresenta a quadratura que envolve o ser:

Habitar, ser trazido à paz de um abrigo, diz: permanecer pacificado na liberdade de um pertencimento, resguardar cada coisa em sua essência. $O$ traço fundamental do habitar é esse resguardo. O resguardo perpassa o habitar em toda a sua amplitude. Mostra-se tão logo nos dispomos a pensar que ser homem consiste em habitar e, isso, no sentido de um demorar-se dos mortais sobre essa terra.

"Sobre essa terra" já diz, no entanto, "sob o céu". Ambos supõem conjutamente "permanecer diante dos deuses" e isso "em pertencendo à comunidade dos homens". Os quatro: terra e céu, os divinos e os mortais, pertencem um ao outro numa unidade originária.

A terra é o sustento de todo gesto de dedicação. A terra dá frutos ao florescer. A terra concentra-se vasta nas pedras e nas águas, irrompe concentrada na flora e na fauna. Dizendo terra, já pensamos os outros três. Mas isso ainda não significa que se tenha pensado a simplicidade dos quatro.

O céu é o percurso em abóbadas do sol, o curso em transformação da lua, o brilho peregrino das estrelas, as estações dos anos e suas viradas, luz e crepúsculo do dia, escuridão e claridade da noite, a suavidade e o rigor dos climas, rasgo de nuvens e profundidade azul do éter. Dizendo céu, já pensamos os outros três. Mas isso ainda não que se tenha pensado a simplicidade dos quatro.

Os deuses são os mensageiros que acenam a divindade. Do domínio sagrado desses manifesta-se o Deus em sua atualidade ou se retrai em sua dissimulação. Se dermos nome aos deuses, já incluímos os outros três, mas não consideramos a simplicidade dos quatro.

Os mortais são os homens. Chamam-se mortais porque podem morrer. Morrer diz: ser capaz da morte como morte. Somente o homem morre e, na verdade, somente ele morre continuamente, ao menos enquanto permanecer sobre a terra, sob o céu, diante dos deuses. Nomeando os mortais, já pensamos os outros três. Mas isso ainda não significa que se tenha pensado a simplicidade dos quatro.

Chamamos de quadratura essa simplicidade. Em habitando, os mortais são na quadratura. O traço fundamental do habitar é, porém, resguardar. Os

${ }^{4}$ Ibidem, p. 128. 
mortais habitam resguardando a quadratura em sua essência. De maneira correspondente, o resguardo inerente ao habitar tem quatro faces. ${ }^{5}$

Em um primeiro momento, a quadratura de Heidegger parece não ter sentido, mas abrigar tal quadratura explica o ser, quando define o seu habitar. Heidegger deixa algumas portas abertas para compreender e definir cada uma das constelações dessa quadratura. Por exemplo, a terra que é "o sustento de todo gesto de dedicação" pode ser considerado como todos os atributos físicos que compõem o ser, passando pelo seu corpo e alcançando todas as suas potencialidades de ação, incluindo as suas posses. Em contraponto, os céus podem referenciar os atributos imateriais que compreendem o ser, incluindo os seus aspectos intelectuais e emocionais que servem tanto para sentir o mundo, como ponto de impulsão para alterá-lo conforme a necessidade, conveniência e desejo.

Por outro lado, "os deuses" podem significar as tradições e valores culturais que envolvem o ser, considerando, inclusive, toda a organização ética da política, moldada pelos contextos históricos decorrentes de cada cultura. Ao mesmo tempo, considera-se o último elo da quadratura, "os mortais", decorrentes das relações sociais do ser com outros seres, segundo a estrutura estabelecida também pelos contextos históricos decorrentes de cada cultura, incluindo estrutura familiar, cidadania, etc.

Compreende-se, então, que o ser é estruturado pelo constante devir, no equilíbrio entre o material e imaterial, e os valores e as relações estabelecendo o "habitar", já que

salvando a terra, acolhendo o céu, aguardando os deuses, conduzindo os mortais, é assim que acontece propriamente um habitar. Acontece enquanto um resguardo de quatro faces da quadratura. Resguardar diz: abrigar a quadratura em seu vigor de essência. $O$ que se toma para abrigar deve ser velado. Onde, porém, o habitar guarda a sua essência quando resguarda a quadratura? Como os mortais trazem à plenitude o habitar no sentido desse resguardar? Os mortais jamais o conseguiriam se habitar fosse tão-só uma de-mora sobre a terra, sob o céu, diante dos deuses, com os mortais. Habitar é bem mais um demorar-se junto às coisas. Enquanto resguardo, o habitar preserva a quadratura naquilo junto a que os mortais se demoram: nas coisas. ${ }^{6}$

Heidegger, introduz, então "as coisas" no processo inerente ao habitar. Mais uma vez, existe espaço para interpretar as possibilidades de significados para as

\footnotetext{
${ }^{5}$ Ibidem, p. 129 e 130.

${ }^{6}$ Ibidem, p. 130 e 131.
} 
definições de Heidegger. É possível, por exemplo, compreender "as coisas" como o contexto tecnológico que permite o equilíbrio da quadratura e, então, possibilita 0 habitar do ser. Essa aproximação se torna possível e até evidente quando o filósofo coloca que

\begin{abstract}
a demora junto às coisas é, no entanto, a mencionada simplicidade a quatro. Essa simplicidade constitui o resguardo mas não como uma quinta coisa acrescentada. Ao contrário. A demora junto às coisas é o único modo em que a demora própria da simplicidade dos quatro alcança na quadratura uma plenitude consistente. No habitar, a quadratura se resguarda à medida que leva para as coisas o seu próprio vigor de essência. As coisas elas mesmas, porém, abrigam a quadratura apenas quando deixadas como coisas em seu vigor. Como isso acontece? Quando os mortais protegem e cuidam das coisas em seu crescimento. Quando edificam de maneira própria coisas que não crescem. Cultivar e edificar significam, em sentido estrito, construir. Habitar é construir desde que se preserve nas coisas a quadratura. $^{7}$
\end{abstract}

Considerando a interpretação sobre as definições de Heidegger como ontologia tecnológica do ser, é possível, tomar o contexto das tecnologias digitais como exemplo e seguir o caminho inverso em uma análise sobre o homem digital. As tecnologias digitais moldam o habitar do homem contemporâneo permitindo-o que habite no mundo (seja e esteja), ao equilibrar as interfaces (corpo e máquinacomputador, definindo a terra) e as informações (inteligência, comunicação, interação e dados digitalizados), ao mesmo tempo em que integra os valores (cibercultura, ciberativismo, ética hacker, prática democrática de comunicação, etc.) na consolidação das relações (demais conectados).

A partir dessa definição da natureza do ser tecnológico, faz-se necessário e possível um aprofundamento nas interconexões entre homem e tecnologia considerando que o homem exprime a sua essência através da técnica e é moldado, transformado e definido por ela.

\title{
1.1.2 - Uma consideração não instrumental da conjunção homem e tecnologia
}

Defendendo conceitualmente que a contemporaneidade é definida pela clara assimilação da técnica não mais como instrumento do homem, mas como sua essência que permite a sua existência e sobrevivência, Umberto Galimberti, professor de história e psicologia geral da Universidade de Veneza, nos apresenta 
uma visão filosófica, social, antropológica e "tecnológica" sobre a relação que existe entre homem e técnica. Fazendo recortes sócio-culturais da história ocidental, bem como fazendo releituras de pensadores e filósofos, confrontando-os e colocando-os em diálogo, Galimberti, em sua obra "Psiche e techne: o homem na idade da técnica" (2006), pontua aspectos de grande relevância para a base teórica que se propõe nesse trabalho.

Galimberti se propõe a apresentar a técnica e sua relação com o homem se valendo de uma visão menos antropocêntrica e, já de início, alerta para a necessidade de

acabar com as falsas inocências, com a fábula da técnica neutra, que só oferece meios, cabendo depois aos homens empregá-los para o bem ou para o mal. A técnica não é neutra, porque cria um mundo com determinadas características com as quais não podemos deixar de conviver e, vivendo com elas, contrair hábitos que nos transformam obrigatoriamente. De fato, não somos seres imaculados e estranhos que às vezes se servem da técnica e às vezes dela prescindem. Pelo fato de habitarmos um mundo em que todas as suas partes estão tecnicamente organizadas, a técnica não é mais objeto de uma escolha nossa, pois é o nosso ambiente, onde fins e meios, escopos e idealizações, consutas, ações e paixões, inclusive sonhos e desejos, estão tecnicamente articulados e precisam da técnica para se expressar. ${ }^{8}$

Para defender a essencialidade técnica para a existência humana, Galimberti considera que o homem, se diferenciando dos demais animais, é constituído de uma "carência biológica", pois não dispõe de nenhum membro especializado (como rabo, garra, bico, etc.) e tem um sistema sensitivo muito inferior aos demais animais, sendo ineficiente tanto como predador ou presa. Para sobreviver, o homem desenvolveu a capacidade de agir tecnicamente e só assim pôde se estabelecer na natureza e construir a sua história. Para Galimberti, "a antecipação, a idealização, a projeção, a liberdade de movimento e de ação, em suma, a história como sucessão de autocriações tem na carência biológica a sua raiz, e no agir técnico a sua expressão."9

Exatamente por ser inferior e carente biologicamente, o homem não sobreviveria no mundo natural/ selvagem. Através da técnica o homem estabeleceu formas de se transformar no sentido de se aprimorar (socialmente e culturalmente) e dialogar com a natureza, para, mais precisamente, construir o seu próprio ambiente,

\footnotetext{
${ }^{7}$ Ibidem, p. 131

${ }^{8}$ GALIMBERTI, Umberto. Psiche e techne: o homem na idade da técnica.São Paulo: Paulus, 2006, p. 8.
} 
não mais natural, mas tecnologicamente e, portanto, artificialmente elaborado. De fato,

hoje a cidade estendeu-se até os confins da Terra, e a natureza reduziu-se a um encrave, a um retalho circundado pelos muros da cidade. Então a técnica, de instrumento nas mãos do homem para dominar a natureza, se torna o ambiente do homem, aquilo que o rodeia e o constitui, segundo as regras daquela racionalidade que, seguindo os critérios da funcionalidade e da eficiência, não hesita em subordinar às exigências do aparato técnico as próprias demandas do homem. ${ }^{10}$

A essa possibilidade de existência e sobrevivência se deve 0 desenvolvimento da técnica como meio, forma e instrumento para alcançar os fins essenciais à vida humana. Com o desenvolvimento tecnológico, novas possibilidades e, portanto, novos fins (novos sentidos) surgem para a atuação do homem e a técnica passa de instrumento das ações para a determinadora dessas ações. Isso pode ser compreendido por que

enquanto a instrumentação técnica disponível era apenas suficiente para aqueles fins nos quais se expressava a satisfação das necessidades humanas, a técnica era um simples meio, cujo significado era inteiramente absorvido pelo fim; mas, quando a técnica aumenta quantitativamente a ponto de se tornar disponível para a realização de qualquer fim, então muda qualitativamente o cenário, porque não é mais o fim que condiciona a representação, a pesquisa, a aquisição dos meios técnicos, mas será a ampliada disponibilidade dos meios técnicos que desvela o leque dos fins que, por meio deles, podem ser alcançados. Assim, a técnica se transforma de meio em fim, não porque a técnica se proponha a algo, mas porque todos os objetivos e fins que os homens se propõem não podem ser atingidos, a não ser pela mediação técnica. ${ }^{11}$

Tal mediação técnica, que resulta da condição inferior da fisionomia humana, condiciona a vida do ser humano não só como possibilitadora de sua existência, mas como sua deteminadora. Fazendo nova comparação com os animais, Galimberti ressalta que

diferentemente dos animais, o homem só dispõe de genéricas e imprecisas pulsões e não daqueles instintos que, articulando um determinado modo de ser no mundo, garantem a todas as espécies animais a própria sobrevivência. Como efeito dessa carência, o homem, para viver, é obrigado a construir um conjunto de artifícios (ou técnicas) capazes de suprir a insuficiência desses códigos naturais que, para os animais, são os instintos. Nesse cenário, o termo "alma" só pode ser pensado em referência a essa radical incompletude que caracteriza a natureza humana e da qual o pensamento técnico é uma compensação. Podemos, então, manter o termo "alma", desde que com ele entendamos a pura e simples memória das operações técnicas idealizadas não tanto para nos libertar do jugo da

\footnotetext{
${ }^{9}$ Ibidem, p. 9.

${ }^{10}$ Ibidem, p. 11.

${ }^{11}$ Ibidem, p. 12.
} 
natureza, mas porque, sem elas, jamais o homem teria uma vida in natura. A técnica é, pois, a condição da existência humana. ${ }^{12}$

A técnica é tal intrínseca à humanidade que, de si, se deriva a constituição interna do homem, já que

(...) "alma", "intelecto", "razão", "consciência", "espírito" são expressões que denominam a esquematização interiorizada do agir técnico, na regularidade e reprodutibilidade dos seus procedimentos, e assim como humanamente a ação técnica é a condição indispensável da existência, não se dá o dualismo entre alma e corpo, mas derivação, nada mais sendo a alma do que a interiorização do esquema do agir técnico, sem o qual o corpo humano não poderia estar no mundo. ${ }^{13}$

Da mesma forma, a técnica possibilitou o desenvolvimento instrumental e ferramental do meio material para que o homem pudesse se ampliar na forma de interagir com o ambiente e controlá-lo, como única forma possível de sobreviver. A isso, pode-se dizer que

construindo ferramentas, que são cópias ampliadas das suas funções, a mão instaura entre o corpo humano e o mundo uma ordem de relações totalmente desconhecida dos animais, que têm na boca e nos dentes os órgãos de relação com o mundo, o ponto mais avançado do seu sistema corpóreo. A passagem do apresamento direto para o apresamento mediato e ampliado pela ferramenta, dentro da ordem da técnica, encontra a sua justificação no fato de que o corpo humano teve a possibilidade de transferir para a mão o campo da sua relação com o mundo, e por isso, desde então, é o único corpo capaz de fazer gestos, porque é o único que exteriorizou a ordem das ferramentas. ${ }^{14}$

Esse contexto ferramental pode ser parametrizado segundo o instinto animal de espécies que constroem abrigos ou que se utilizam do meio material para ampliar suas possibilidades. Mas, ainda assim, é possível detectar uma clara diferença entre o sentido da ação técnica de animais e homens na sua relação com o ambiente, pois

se um esboço do possível pode ser encontrado no comportamento daqueles pássaros que usam gravetos para construir ninhos, ou dos macacos que usam um galho para trazer para perto de si a banana, devemos observar que esse emprego instrumental das coisas não ultrapassa o ambiente, limitando-se a organizá-lo melhor para torná-lo funcional às próprias necessidades. O homem, em vez disso, quando constrói ferramentas, não o faz somente para melhor organizar o ambiente, mas para preparar outros ambientes que Ihe permitam ultrapassar o dado. O sentido da técnica está todo aí, em reconhecer para além do ambiente atual um ambiente possível, um ambiente que se desenha não por uma intuição da alma, mas porque a ele conduz a cadeia dos instrumentos construídos um depois do outro,

\footnotetext{
12 Ibidem, p. 75-76.

${ }^{13}$ Ibidem, p. 79.

${ }^{14}$ Ibidem, p. 84.
} 
segundo aquela modalidade que, em todos os pontos da série, permite descobrir um outro mundo. ${ }^{15}$

Para o homem não existe a possibilidade de adaptação ao meio natural. Pelo contrário, o homem precisa adaptar o meio segundo a conveniência das suas necessidades básicas de sobrevivência. Isso quer dizer “(...) que o homem, para viver, é obrigado biologicamente a dominar a natureza e que a técnica, medium desse domínio, pertence à essência do homem como condição imprescindível da sua existência."16 Se o homem só existe por conta do desenvolvimento técnico, vale concluir que a técnica é a própria essência do homem.

\title{
1.1.3 - A técnica e a cultura
}

A técnica, como meio único que permite a sobrevivência humana, é também responsável pelo desenvolvimento cultural das sociedades. A esse conceito Galimberti escreve que

\begin{abstract}
não dispondo de uma harmonia preestabelecida entre corpo e mundo, o homem, para viver, teve de elaborar determinadas técnicas, como: a orientação e interpretação do mundo (o qual jamais lhe foi oferecido como imediata e natural habitação), a representação e a transformação previsional daquilo que existe, em sentido útil à sua vida, a tomada de posição em relação às próprias e indeterminadas pulsões, tão genéricas quando comparadas aos instintos animais e, por efeito dessa generalidade, tão expostas a uma torrente de estímulos, em que estão ausentes os instintos específicos que caracterizam a vida animal.

Daí os controles e as inibições (em que se pode ver o primeiro núcleo da moral) necessários à regulação das relações intersubjetivas, bem como os instrumentos materiais e as produções do pensamento, como interpretações e teorias, às quais se procura ligar a legitimidade e, portanto, a normatividade dos controles e das proibições, que, transmitidos pela educação, modelaram a família, a comunidade, a sociedade, tornando a vida praticável e simples, tal como é para o animal. Nesse sentido, é possível concluir, com A. Gehlen, que "a cultura faz parte das condições físicas da existência. Essa afirmativa não seria válida para nenhum animal." ${ }^{17}$
\end{abstract}

Como ponto de partida necessário para o surgimento das culturas, a técnica requer da fisiologia humana adaptações neurológicas para o suporte necessário à formação dos valores culturais. Significa dizer que o cérebro humano amadurece a ponto de dar bases à instauração de um complexo sistema decisório que predeterminam a ação humana. Essas bases, sendo consideradas como

\footnotetext{
${ }^{15}$ Ibidem, p. 91.
}

${ }^{16}$ Ibidem, p. 104. 
preliminares à formação cultural, se mostram essenciais para a sobrevivência humana porque são "expressões dessa técnica inibitória, na ausência da qual o homem seria no mundo um ser desorientado."18

Surge, pela cultura, novas formas técnicas de absorver sensorialmente as informações do mundo, bem como novas formas técnicas de agir nesse mesmo mundo. Isso, porque "se chamamos de "cultura" a capacidade de selecionar, a cultura condiciona o próprio amadurecimento biológico do aparelho sensóriomotor."19

Caracterizando uma rotina de tentativa e erro, a técnica permite que o homem se desenvolva culturalmente através do aprendizado possível no meio habitado. Carente de instintos, o homem age e reage, aprendendo a se adaptar, ou melhor, a controlar, através da técnica, o meio natural hostil à sua sobrevivência. Sem especialidades e, portanto, com condição de vida extremamente genérica, o homem porta, através do aprendizado, uma característica extremamente plástica, ou seja, consegue encontrar meios técnicos de dominação de vários ambientes naturais, sendo possível se instalar e sobreviver em qualquer lugar. A isso é possível dizer que

(...) o homem, desprovido de meios de defesa orgânicos, com recursos sensoriais medíocres, estrutura pulsional não orientada, dependência infantil prolongada, amadurecimento tardio, apresenta uma falta de especialização tão marcada que é praticamente impossível indicar qual "ambiente", ou seja, qual conjunto de condições naturais e originais seria exigido para que o homem pudesse viver. Por isso, encontramos o homem em todos os lugares: no pólo, no equador, na água, na terra firme, na floresta, no charco, nos montes, na estepe. De fato, por toda parte esse ser desprovido de determinação instintiva - e, portanto, de especialização e coordenação ambiental - conseguiu, ativando a técnica, transformar e tornar todos os tipos de condições naturais adequados a ele. ${ }^{20}$

Através da técnica o homem dialoga com a natureza para adequá-la às suas necessidades de sobrevivência não só no sentido material. Além de transformar o meio natural em artifícios para o abrigo, proteção e sustento, o homem se relaciona com a natureza também no sentido de compreendê-la e enxergá-la segundo a sua própria capacidade de dar sentido e significados para as coisas. Isso significa dizer que o homem constrói o mundo quando o interpreta segundo a sua perspectiva

\footnotetext{
${ }^{17}$ Ibidem, p. 104-105.

18 lbidem, p. 192.

${ }^{19}$ Ibidem, p. 111.

20 Ibidem, p. 108-109.
} 
técnica. A verdade a ser descoberta deixa de ser previamente absoluta e definida, como propõe as visões míticas e religiosas, para ser construída e produzida através do saber e de fato "é possível dizer que as verdades se constroem e que a técnica é o instrumento que conduz à sua construção." ${ }^{21}$

A capacidade de construir a verdade e, portanto o seu mundo, para possibilitar a própria existência, permitiu ao homem que elaborasse imagens sobre 0 futuro possível, ou seja, que conquistasse a capacidade de imaginar os acontecimentos vindouros e, assim, se adaptar para a continuação de sua existência, com base na adequação imaginativa das ações vividas e assimiladas na memória. Compreendendo que o futuro não é uma simples contextualização do passado, a memória sobre as experiências passadas são reelaboradas por uma técnica de "operação transpositiva" de imaginação que "verifica quais aquisições do passado ou quais combinações das aquisições, independentemente das situações concretas em que foram experimentadas, se adaptam às novas situações que o futuro desvela." 22 Somente através dessa transposição imaginativa é possível ao homem se adequar às novidades e incertezas do futuro ao alcançar novos paradigmas, sem estar preso instintivamente nas ações do passado, mas aprendendo e evoluindo com elas.

\subsection{4 - A técnica como meio e fim na formação do homem}

Nesse sentido, o homem tende almejar a descoberta para, através dessa inteligência, construir e dominar o mundo. $O$ homem busca o desvelamento através das ações técnicas, sendo que tanto "diante do belo artístico quanto da experimentação científica nos sentimos levados 'em direção de' uma abertura que não visa ao alcançamento de um resultado, e sim à mudança no uso habitual da experiência." ${ }^{23} \mathrm{~A}$ ação técnica, que permite essa mudança de experimentação e vivência, ao ser o único caminho possível para a jornada humana, deixa a sua condição de medium para se tornar um fim em si. A isso, Galimberti coloca que

se a técnica se tornasse, como parece ter ocorrido, a condição universal (meio) para a produção dos bens e para a satisfação das necessidades (fim), o alcance de um adequado aparato técnico se torna o primeiro fim, para a consecução do qual, se for necessário, sacrifica-se até a produção dos bens e a satisfação das necessidades.

\footnotetext{
21 lbidem, p. 278.

22 lbidem, p. 220.

23 lbidem, p. 223.
} 
É esse o modo pelo qual a técnica se transforma de meio em fim e, automatizando-se em relação às necessidades, aos desejos e aos motivos que estão na base da ação humana, coloca-se como a primeira necessidade, o primeiro desejo e o primeiro motivo a orientar a ação humana. Desse modo, de meio universal para a consecução de qualquer fim, a técnica se transforma em fim supremo, para o qual convergem as infinitas séries de fins, que se dobram a esse meio, porque desse meio depende a sua realização. ${ }^{24}$

E complementa, afirmando que

A possibilidade de uma ilimitada utilização, graças à progressiva automatização da técnica em relação a qualquer conteúdo finalista, faz com que seja justamente a ausência interna de significado da técnica a gerar a plenitude de significados. O meio técnico, se de um lado não constitui um ponto de chegada para nenhum projeto, do outro é o ponto de passagem para a realização de qualquer projeto. ${ }^{2}$

Convergindo em si o fim e o meio, a técnica conecta os objetivos e os procedimentos, ou seja, o saber e o poder. Dessa forma "como conexão de saber e poder, a técnica é aquilo de que a vontade antes de tudo precisa para se expressar como vontade, e assim se diferenciar do sonho ou do desejo irrealizado." ${ }^{26}$ Nesse sentido, a vontade de alcançar um determinado fim através de um determinado meio se mistura com a vontade de se valer do próprio meio. A técnica, então, é ponto de partida para a elaboração da própria vontade.

A vontade do homem remete diretamente à sua liberdade de escolha. Mas com a supremacia da técnica como o principal fim a ser alcançado que permite todos os demais fins, essa vontade e liberdade de escolha acabam se atrelando às possibilidades da técnica "que desvela o horizonte das disponibilidades e torna possível a sua realização. ${ }^{27} \mathrm{O}$ homem só pode ter vontade, bem como vislumbrar a liberdade de escolha, dentro do leque de opções das possibilidades apresentadas e/ou previstas pela técnica.

Como o meio pelo qual se possibilita a existência humana e que determina as suas possibilidades de ação, vontade e liberdade,

(...) a técnica, em sua expressão moderna, se torna esse horizonte último a partir do qual se desvelam todos os campos da experiência. Não mais a experiência que, reiterada, estabelece o procedimento técnico, mas a técnica como condição que decide o modo de se fazer a experiência. Aí assistimos a uma transformação da subjetividade: não mais o homem como sujeito e a técnica como instrumento à sua disposição, mas a técnica que

\footnotetext{
${ }^{24}$ Ibidem, p. 265-266.

${ }^{25}$ Ibidem, p. 374.

${ }^{26}$ Ibidem, p. 281.

27 lbidem, p. 374.
} 
dispõe da natureza como de um fundo de reserva e do homem como um seu funcionário. ${ }^{28}$

Nesse sentido, "o homem não é mais sujeito, mas algo 'disposto' no horizonte desvelado pela técnica, que é, pois, o que decide o modo de o homem perceber, sentir, pensar e projetar., ${ }^{29} \mathrm{E}$ considerando uma abordagem mais filosófica para compreender a subjetividade humana, "como seu ambiente, a técnica é aquilo em relação ao qual o homem de hoje chega ao conhecimento de si. ${ }^{, 30} \mathrm{O}$ homem se constrói pela técnica e, mais uma vez, é possível concluir que a técnica é a essência do homem.

\subsection{5 - Potencialidades na era da técnica}

Para definir a era da técnica, Galimberti considera que no momento em que "o uso da técnica não tem mais em vista uma finalidade (nem mesmo o lucro), mas só a própria potencialização" ${ }^{31}$, qualquer fim almejado pelo homem fica submetido à disponibilidade técnica e, por isso, "a potencialização dessa disponibilidade termina por representar o único verdadeiro fim." ${ }^{32}$ Nesse instante, a técnica passa a determinar e possibilitar todos os caminhos do homem.

Mesmo considerando valores éticos e sócio-culturais que conflitam com o avanço desenfreado da tecnologia, estes se enfraquecem diante da própria inevitabilidade de tal avanço. É possível considerar, então, que “(...) não é mais a ética que promove a técnica, mas é a técnica que condiciona a ética, obrigando-a a tomar posição a partir de uma realidade, não mais natural, mas artificial, que a técnica não cessa de construir e tornar possível, qualquer que seja a posição assumida pela ética." ${ }^{33}$

De fato, a discussão ética acontece porque as potencialidades técnicas, em seu desenvolvimento exponencial, trazem questões antes nunca problematizadas. $O$ meio técnico exige um questionamento dos valores humanos em confronto com a virtual ilimitação tecnológica. E tal ambiente tecnológico é, em si, uma segunda

\footnotetext{
28 Ibidem, p. 381.

29 Ibidem, p. 383.

30 Ibidem, p. 391

${ }^{31}$ Ibidem, p. 446.

32 Ibidem, p. 446

33 Ibidem, p. 519
} 
natureza onde o homem estabelece um vínculo de auto-sobrevivência, pois "se é verdade que a técnica é um produto da atividade humana, é também verdade que esse produto depois se cristaliza, se fixa, se separa e se autonomiza da atividade que o gerou, para colocar-se como imprescindível condição para o ativar-se de novas atividades."34

O vínculo estabelecido entre o homem e a técnica supera a dependência mútua entre os indivíduos que agora, pelos procedimentos técnicos (das quais são dependentes), têm suas dependências pessoais resolvidas quando a técnica se torna suficiente para potencializar a sua sobrevivência. Isso significa que "se a técnica libertou o homem do vínculo da natureza e do vínculo que o sujeitava a um outro homem, pôde fazê-lo colocando a si mesma como vínculo de todos os vínculos, como elaboração secundária e substitutiva do vínculo natural e do vínculo antropológico."35

Desse modo, "a técnica não é uma 'coisa' entre as demais que estão à disposição do homem, mas é o medium por meio do qual os homens percebem, pensam e expressam as relações com os seus semelhantes e com o mundo em que coabitam." ${ }^{36}$ Sobre isso é possível citar o conceito de McLuhan que compreende que "é o meio que configura e controla a proporção e a forma das ações e associações humanas"37, ou seja, as técnicas estendem e potencializam o homem e, ao mesmo tempo, ditam a proporção das suas ações.

Galimbert vai além das ações individuais e defende que o vínculo com a técnica permite que se desenvolva um relacionamento entre os indivíduos com teor mais funcional, ou seja, o homem é elaborado, segundo as condições técnicas, a interagir com seus semelhantes por sua funcionalidade social, pois

A produção da técnica mediante a sua reprodução faz com que a técnica não seja só produção de instrumentos, mas produção de relações sociais mediante instrumentos que convocam os homens enquanto representantes de funções. Isso significa que os instrumentos produzidos pela técnica são só os termos médios de relações entre funções, por detrás das quais se escondem indivíduos que perdem a própria individualidade no ato mesmo em que percebem a sociabilidade como própria da função, como algo que não Ihes diz respeito enquanto indivíduos, mas enquanto funcionários. ${ }^{38}$

\footnotetext{
${ }^{34}$ Ibidem, p. 639.

${ }^{35}$ Ibidem, p. 641.

${ }^{36}$ Ibidem, p. 646.

${ }^{37}$ MCLUHAN, Marshall. Os meios de comunicação como extensões do homem. Rio de Janeiro: Editora Cultrix, 1964, p. 23.

${ }^{38}$ GALIMBERTI, Umberto. Psiche e techne: o homem na idade da técnica.São Paulo: Paulus, 2006, p. 642-643.
} 


\subsection{6 - A tecnologia da informação}

Para Galimberti, a concepção de que a técnica acaba por construir um mundo artificial como palco para a atuação humana é muito evidente no caso das tecnologias de comunicação, onde a informação elabora um ambiente de ação e interação. Os meios de comunicação devem ser considerados não como "simples meios' para ocultar o fato de que são um mundo em via de substituir o mundo."39

Mais evidente é o caso da internet, pois "o 'ciberespaço', é um mundo, portanto algo radicalmente diferente de um meio porque, diferente do 'meio' que cada um pode empregar para fins que escolhe, com o 'mundo' não se dá outra liberdade senão aquela de participar dele, ou dele manter-se afastado." ${ }^{40}$ Além dessa condição de ambiente de habitar, é necessário se ater ao fato de que, pela técnica educativa e informativa de fato o homem constrói a sua verdade e, portanto o seu mundo, já que

a informação deixa de ser um "relatório" para se traduzir numa verdadeira "construção" dos fatos, e isso não no sentido de que muitos fatos do mundo não teriam relevância se a mídia não no-los propusesse, mas porque um enorme número de ações não seria realizado se os meios de comunicação não as noticiassem. Hoje o mundo acontece porque é comunicado, e o mundo comunicado é o único ao qual habitamos. ${ }^{41}$

$\mathrm{Na}$ cultura imagética dos meios de comunicação eletrônicos, "a televisão, distribuindo sem cessar o significado das coisas e o seu variado uso, prossegue o trabalho da educação, que codifica, não porque manipula, engana, mente, mas simplesmente porque descreve o mundo, o qual não existe fora da sua descrição." ${ }^{42}$ De fato, a mídia transmite uma representação de mundo

entregando-nos uma presença sem dimensão espaço-temporal, porque retesada na simultaneidade e na pontualidade do instante, modificando o nosso modo de fazer experiência, aproximando de nós o distante e afastando o próximo, familiarizando-nos com o estranho e fornecendo-nos códigos virtuais para a interpretação do mundo real, produzem modificações no homem independentemente das modalidades de uso da própria mídia. Por isso, negamos que os meios de comunicação sejam somente "meios". Se o telefone, o rádio, a televisão, o computador determinam um novo relacionamento entre nós e os nossos semelhantes, entre nós e as coisas,

\footnotetext{
${ }^{39}$ Ibidem, p. 723.

${ }^{40}$ Ibidem, p. 724

${ }^{41}$ Ibidem, p. 726.

${ }^{42}$ Ibidem, p. 725.
} 
entre as coisas e nós, então os meios de comunicação nos plasmam, qualquer que seja o objetivo pelo qual os empregamos, e antes mesmo que atribuamos a eles um objetivo. ${ }^{43}$

E mesmo que as imagens do mundo sejam comuns, a experiência de vivenciar e experimentar esse mundo se dá de uma forma pessoal e não compartilhada. Principalmente no contexto das redes digitais informativas, observase que

(...) para a internet, na qual o "consumo em comum" do meio não equivale a uma real "experiência comum". O que, na internet, se intercambia, de fato, é sempre uma realidade pessoal que não se torna nunca uma realidade compartilhada, porque o intercâmbio tem um ritmo solipsístico, no qual um número infinito de eremitas de massa comunica visões de mundo apreendidas a partir do seu eremitério, para os quais, tal qual os eremitas de outrora, cada um se retira, não para renunciar ao mundo, mas para não perder nenhum fragmento desse mundo em imagem. ${ }^{44}$

E esse mundo em imagem é justamente o ambiente em que vivemos. Seja para trabalhar ou para nos relacionarmos com nossos semelhantes, seja para aprender ou para "brincar". Vivemos nesse mundo construído pela informação e não mais pelos fatos. "Não mais um mundo de fatos e depois a informação, mas um mundo de fatos pela informação." ${ }^{\text {45 }}$

\section{2 - Contexto tecnológico midiático na contemporaneidade}

Outra noite tive o imenso prazer de me encontrar com um amigo da família em um jantar extremamente agradável. Sua caminhada profissional, facilmente considerada de sucesso, acompanha diretamente os desenvolvimentos das tecnologias comunicativas dos últimos anos e me deram insights para conseguir, se não compreender, pelo menos observar a nossa era informacional com mais critério.

Como editor-chefe de uma importante emissora televisiva do Centro-Oeste brasileiro, esse amigo sempre esteve em contato com as imensas cifras destinadas às novidades tecnológicas de comunicação de massa. De seu ímpeto quase

\footnotetext{
43 Ibidem, p. 731.

44 Ibidem, p. 737.

45 Ibidem, p. 726.
} 
frenético em falar sobre as suas ações e decisões, surgiram alguns temas que guardei para refletir com mais atenção.

Uma primeira observação muito mais técnica do que reflexiva foi sobre o barateamento absurdo dos equipamentos voltados para a produção multimidiática. E a observação feita é que a internet, como espaço onde os atores não se definem mais pelo modelo analógico de distinção clara entre poucos produtores (as grandes emissoras, por exemplo) e muitos receptores (a massa), permite a expressão coletiva, comunitária e individual com custo tendendo ao zero (e existem vários casos gratuitos como os blogs, por exemplo).

Reforçando essa tendência de produção informativa a baixo custo, a tecnologia digital, em processo de difusão popular, derrubou o preço de câmeras (até embutidas nos telefones celulares) e ilhas de edição (já acopladas nos hardwares e sistemas operacionais básicos de qualquer PC - Personal Computer). Surgiram, ao mesmo tempo, plataformas online de exibição e compartilhamento das produções audiovisuais populares (seja vídeo, música, literatura etc.).

Como pesquisador de comunicação digital, achei tal observação um tanto clara, mas fiquei entusiasmado pela confirmação de um profissional da área. Mas o que me chamou a atenção foi uma observação mais pessoal desse amigo. Mesmo por estar em contato com a tecnologia em todos os seus dias, sua casa é sempre recheada de elementos tecnológicos. Um computador pessoal extremamente sofisticado e com capacidade de processamento de edição de vídeo acima da média fazem parte do inventário. Mas junto com os bits, RAMs, HDs, placa disso e memória daquilo, vem a dor de cabeça da manutenção. Se alguma coisa dá errado... se perdeu a rede wireless... se o sistema operacional trava... A possibilidade de ter problemas aumenta junto com o incremento de um computador. A solução: "Mandei o meu filho de 15 anos fazer um curso de hardware para resolver todos os problemas lá de casa... e não é que funcionou? Ele sempre gostou disso e sempre teve facilidade..."

"Fantástico!", pensei. O adolescente de hoje tem muita facilidade em resolver questões complexas de hardware e de software e vê isso como um quebra-cabeça a ser entendido e resolvido, sentindo prazer na busca da solução.

Teclados e mouse estendem as nossas mãos como um meio para se chegar a um fim (trabalho, pesquisa, essa dissertação...). Mas para as novas gerações, o digital não é um fim, mas é o próprio contexto, o próprio texto, é o próprio meio. É o 
próprio meio de/para/porquê/como aprender, trabalhar, se relacionar, se divertir, se estressar...

Tudo parece convergir na tecnologia digital. Daqui parto para uma análise mais acadêmica. Até mais.

A comunicação é ponto chave para a sobrevivência e vivência do ser humano em grupos sociais desde os primórdios de sua existência. A história só existe por causa das reminiscências das formas de comunicação utilizadas em tempos passados, encontradas posteriormente. Assim, pode-se dizer que a história humana, se não é a história de sua comunicação, é ao menos identificável pelas formas de comunicação estabelecidas em outros momentos e que, de forma clara ou por meio de pistas, revelam o cotidiano de sociedades que já não existem, ou porque evoluíram ou porque sucumbiram diante de outras.

Os entalhes nas arquiteturas egípcias ou maias, obras de arte de pintura e escultura do renascimento, livros e ilustrações elaborados nos séculos passados, todas as formas de comunicação, dentre elas as manifestações intelectuais e artísticas, colaboram para ilustrar sociedades em tempos específicos. Para o século $X X$, a comunicação em telas de cinema, em rolos de filmes documentais e arquivos de televisão e rádio se tornam essenciais para registrar o momento social de várias realidades do mundo. A comunicação é resultado direto da necessidade do ser humano, como ser social, em interagir e socializar.

Então, faz-se necessário analisar, de forma sintética, os impactos que as tecnologias comunicativas provocaram nos aspectos culturais, sociais e na própria forma do homem estar e ser no mundo, ou seja, na sua própria formação. $E$ tal formação advém da informação que tece seus padrões racionais, lógicos, intuitivos e também os seus valores morais, culturais, sociais e relacionais. Segundo o sociólogo italiano radicado no Brasil Di Felice ${ }^{46}$,

olhar a história das transformações comunicativas não significa, portanto, perceber somente a mudança das formas de armazenar, organizar e comunicar as informações num sentido evolutivo, mas compreender 0

\footnotetext{
${ }^{46}$ Massimo Di Felice é professor da Escola de Comunicações e Artes da Universidade de São Paulo (ECA/USP) e pesquisa os impactos das tecnologias digitais, coordenando o Centro de Pesquisa em Comunicação Digital ATOPOS.
} 
caráter qualitativo de cada ruptura comunicativa e, com esta, a cada frase, a introdução de uma nova forma de sentir o mundo e de definir a realidade. ${ }^{47}$

Dessa forma, ao analisar a passagem da oralidade para escrita, para a imprensa, para as mídias eletrônicas e, recentemente, para as mídias digitais, o homem e a sua relação com a tecnologia são transformados de modo a formatar um novo estar e sentir no mundo. Segundo o autor, na história da humanidade, até então, existem "três momentos importantes que marcaram não apenas o surgimento de uma nova forma de comunicar e de novos meios, mas também a introdução de novas possibilidades de comunicação e, conseqüentemente, de novas práticas de socialização e de interação com o meio ambiente" ${ }^{\text {"48 }}$.

A cada um desses três momentos ou, como o autor define, "revoluções comunicativas", é possível identificar uma datação e localidade onde

\begin{abstract}
a primeira revolução surge com a escrita no século V a.C., no Oriente Médio, e marca a passagem da cultura e da sociedade oral para a cultura e a sociedade da escrita. A segunda, ocorrida na metade do século $X V$, na Europa, provocada pela invenção dos caracteres móveis e pelo surgimento da impressão criada por Johannes Gutenberg, causará a difusão da cultura e do livro e da leitura até então circunscrita a grupos privilegiados. A terceira, desenvolvida no Ocidente, na época da Revolução Industrial, entre os séculos XIXe XX, foi marcada pelo inicio da cultura de massa e caracterizada pela difusão de mensagens veiculadas pelo meios de comunicação eletrônicos. ${ }^{49}$
\end{abstract}

Nas culturas orais, a maior reunião social possível eram as tribos. Com a tecnologia escrita formam-se reinados e dinastias imperiais. Com a imprensa surgem os estados nacionais e os núcleos urbanos. Com o advento das mídias eletrônicas surgem as grandes metrópoles e a intensificação das relações internacionais. Em cada uma das revoluções comunicativas propostas por Di Felice, é possível perceber que aumenta a quantidade de informação necessária e oferecida para um número cada vez maior de pessoas alcançadas por tais informações. Além disso, pela tecnologia, diminui-se o tempo de disseminação das informações de maneira cada vez mais barata. De maneira objetiva, é possível observar o quanto as tecnologias comunicativas permitem a aglomeração das formações sociais

${ }^{47}$ DI FELICE, Massimo. "Das tecnologias da democracia para as tecnologias da colaboração" in DI FELICE, Massimo (org.). Do público para as redes: a comunicação digital e as novas formas de participação social. São Caetano do Sul, SP: Difusão Editora, 2008, p. 21.

${ }_{48}$ Ibidem, p. 21.

${ }^{49}$ Ibidem, p. 21 e 22. 
possibilitando "não apenas novas práticas comunicativas, mas também novas práticas sociais e novas formas de interação com a paisagem" ${ }^{50}$.

Para o autor,

$\mathrm{Na}$ época contemporânea, a humanidade estaria enfrentando uma ulterior revolução comunicativa, implementada pelas tecnologias digitais, que, numa concepção histórica, constituiria a quarta revolução e que, como as outras, estaria ocasionando importantes transformações no interior dos distintos aspectos do convívio humano. Nesta última parte, além da expansão do elemento comunicativo, que passará a permitir o alcance das informações a um público ilimitado e a transmissão em tempo real de uma quantidade infinita de mensagens, é o próprio processo e o próprio significado do ato de comunicar a serem radicalmente transformados. ${ }^{51}$

De modo semelhante e com a mesma identificação de quebras de paradigma com o advento das tecnologias comunicativas digitais, o sociólogo Manuel Castells, pesquisador extremamente alinhado com o impacto dos meios de comunicação, defende que a nova geração será totalmente impactada pela tecnologia. Isso porque o mundo assiste ao "surgimento de uma nova estrutura social, manifestada sob várias formas conforme a diversidade de culturas e instituições em todo o planeta. Essa nova estrutura social está associada ao surgimento de um novo modo de desenvolvimento, o informacionalismo"52.

No mesmo sentido, o historiador Alvin Toffler descreve o nosso momento como uma revolução social denominado como "Idade da Informação", onde

as mudanças súbitas que estamos experimentando agora não são caóticas ou fortuitas, mas que, de fato, formam um padrão vivo e claramente discernível - que contribuem para uma gigantesca transformação na maneira como vivemos, trabalhamos, brincamos e pensamos e que é possível um futuro escorreito e desejável. Em resumo, o que se segue começa com a premissa de que o que está acontecendo agora é nada menos que uma revolução global, um pulo de um quantum na História. ${ }^{53}$

A importância das novas possibilidades se dá pelo fato das redes digitais de comunicação oferecerem o contexto tecnológico para o surgimento de novos tipos de relações e ações humanas, incluindo as manifestações artísticas, políticas econômicas e sociais. E todas essas ações são permeadas pela informação digitalizada e disseminada em rede.

A professora Lucia Santaella considera que o funcionamento da internet

${ }^{50}$ Ibidem, p. 22.

51 Ibidem, p. 22 e 23.

${ }^{52}$ CASTELLS, Manuel. A Sociedade em rede. São Paulo: Paz e Terra, 1999. p.32-33. 
depende não apenas do papel capital desempenhado pela informática e pelos computadores, mas da comunicação que se institui entre eles por meio da conexão em rede. As duas forças principais da informática, capacidade de armazenamento e processamento da informação, multiplicam-se imensamente na medida em que as máquinas podem se beneficiar uma das outras. Na internet, a palavra "rede" deve ser entendida em uma acepção muito especial, pois ela não se constrói segundo princípios hierárquicos, mas como se uma grande teia na forma do globo envolvesse a terra inteira, sem bordas nem centros. Nessa teia, comunicações eletrônicas caminham na velocidade da luz (300 mil km/s), em um "tempo real", pode-se dizer, no qual a distancia não conta. ${ }^{54}$

É notável que em pouco mais de meio século de desenvolvimento, desde os embriões computacionais (que ocupavam grandes salões) até os $P C$ s domiciliares, a comunicação mediada por computador tenha alcançado tantos usuários que tentam se atualizar na frenética corrida tecnológica comunicacional. É claro que isso decorre, em parte, de uma exploração comercial sobre a informática e sobre uma clientela potencial. Porém, é preciso reconhecer que o encanto da rede das redes (Internet) revela-se como a realização da humanidade em prover a interligação mundial e o diálogo aberto e democrático.

\subsection{1 - Comunicação e interação no ciberespaço formando a inteligência conectiva e coletiva}

No momento presente, denominado como era da informação ou sociedade informacional, a comunicação, sempre essencial para a existência social da humanidade, toma características peculiares pela enorme quantidade de informações alcançadas e acumuladas e pela tecnologia advinda desse conhecimento. Pode-se considerar que a mediação feita pelo computador para a circulação de tantas informações abre um novo espaço de relação da comunicação. Esse novo espaço, conhecido como ciberespaço, transpassa barreiras de distância e torna a viagem informacional quase instantânea. Pierre Lévy define ciberespaço e cibercultura, resultado das ações humanas nesse contexto, como:

(...) o novo meio de comunicação que surge da interconexão mundial dos computadores. O termo especifica não apenas a infra-estrutura material da comunicação digital, mas também o universo oceânico de informações que ela abriga, assim como os seres humanos que navegam e alimentam esse universo. Quanto ao neologismo "cibercultura", especifica aqui o conjunto de

${ }^{53}$ TOFFLER, Alvin. A terceira onda. São Paulo: Record, 1995. p.26.

${ }^{54}$ SANTAELLA, Lúcia. Navegar no ciberespaço: o perfil cognitivo do leitor imersivo. São Paulo: Paulus, 2004, p. 38. 
técnicas (materiais e intelectuais), de práticas, de atitudes, de modos de pensamento e de valores que se desenvolvem juntamente com 0 crescimento do ciberespaço. ${ }^{55}$

A cibercultura, definida no contexto do ciberespaço, promove a exaltação do indivíduo e do coletivo no sentido de dar voz, cara e presença a todos os que fazem parte desse mundo, onde se tem acesso à informação e se deve colaborar para a expansão do território informacional, tão limitado quanto for limitada a história humana. Para promover o crescimento de conhecimento sem o perigo da concentração, centralização e monopolização (próprias da lógica capitalista) a sociedade pode assumir papel ativo e não-passivo das comunicações o que "implica o reconhecimento do outro, a aceitação e ajuda mútuas, a cooperação, a associação, a negociação, para além das diferenças de pontos de vista e de interesses" ${ }^{\prime \prime 5}$.

Sobre o ciberespaço, Santaella acrescenta que

(...) se refere a um sistema de comunicação eletrônica global que reúne os humanos e os computadores em uma relação simbiótica que cresce exponencialmente graças à comunicação interativa. Trata-se, portanto, de um espaço informacional, no qual os dados são configurados de tal modo que o usuário pode acessar, movimentar e trocar informação com um incontável número de usuários. ${ }^{57}$

E ainda, que

(...) é um espaço feito de circuitos informacionais navegáveis. Um mundo virtual de comunicação informática, um universo etério que se expande indefinidamente mais além da tela, por menor que esta esteja, podendo caber até mesmo na palma da mão. ${ }^{58}$

A história da Internet revela que, assim como os desbravadores que exploraram os oceanos para alcançar novos continentes, ou aqueles que caminharam até a máquina a vapor e, mais tarde, a mecatrônica, "o crescimento do ciberespaço resulta de um movimento internacional de jovens ávidos para experimentar, coletivamente, formas de comunicação diferentes daquelas que as mídias clássicas nos propõem" ${ }^{59}$. Essa descrição de Pierre Lévy lembra o processo lúdico e pedagógico de reconhecer e experimentar o mundo, próprio da fase da

\footnotetext{
${ }^{55}$ LÉVY, Pierre. Cibercultura. São Paulo: Ed. 34, 1999, p. 17.

${ }^{56}$ Ibidem, p.14.

${ }^{57}$ SANTAELLA, Lúcia. Navegar no ciberespaço: o perfil cognitivo do leitor imersivo. São Paulo: Paulus, 2004,p. 45.

58 lbidem, p. 45 e 46.

${ }^{59}$ LÉVY, Pierre. Cibercultura. São Paulo: Ed. 34, 1999, p. 11.
} 
infância, mas que envolve a qualquer um, sem distinção por faixa etária, quando se tratando de novas tecnologias.

E esse termo utilizado pelo autor, ciberespaço, abarca um novo horizonte para experimentações e explorações e que é impulsionado por essas explorações. Os caminhos conquistados e pré-traçados até o momento atingem vários aspectos sociais inerentes ao ser humano. É possível identificar que a comunicação mediada por computador privilegia as relações econômicas (sites de organizações e de compra), a comunicação por interesse (fóruns e blogs), comunicação entre indivíduos (e-mail e e-groups), educação (à distância e cursos on-line), pesquisas (por exemplo, o Projeto Genoma), entre outras ações humanas incluindo a produção artística (sites de compartilhamento e de divulgação de peças audiovisuais, por exemplo). E é interessante notar que os exploradores não se limitam às grandes organizações ou a comunidades de pesquisa. Os grandes exploradores e indutores de seu desenvolvimento são os próprios usuários.

Para Massimo Di Felice, a grande inovação peculiar da tecnologia de comunicação digital e do contexto do ciberespaço está no fato de que

\begin{abstract}
pela primeira vez na história da humanidade, a comunicação se torna um processo de fluxo em que as velhas distinções entre emissor, meio e receptor se confundem e se trocam até estabelecer outras formas e outras dinâmicas de interação, impossíveis de serem representadas segundo os modelos dos paradigmas comunicativos tradicionais (Shannon-Weaver, Katz-Lazarsfeld, Eco-Fabbri, etc. $)^{60}$
\end{abstract}

Se a relação unidirecional e dialética do papel do emissor, meio e receptor não se aplica no contexto do ciberespaço, ou seja, se todos os conectados são pontos de troca de informação e interação, o ciberespaço só tem solidez estrutural e sentido existencial quando integra e conecta os vários nós (no sentido de pontos de interligação e junção e também da conjulgação da primeira pessoa do plural) da rede em coletividade.

Exatamente pelo fato da estrutura física de cabos e computadores estar em integração com a própria comunicação realizada entre os usuários, Santaella nota que

nessa realidade, da qual cada computador é uma janela, os objetos vistos e ouvidos não são nem físicos nem, necessariamente, representações de

${ }^{60}$ DI FELICE, Massimo. "Das tecnologias da democracia para as tecnologias da colaboração" in DI FELICE, Massimo (org.). Do público para as redes: a comunicação digital e as novas formas de participação social. São Caetano do Sul, SP: Difusão Editora, 2008, p. 23. 
objetos físicos, mas têm a forma, caráter e ação de dados, informação pura. É certamente uma realidade que deriva em parte do funcionamento do mundo natural, físico, mas que se constitui de tráfegos de informação produzida pelos empreendimentos humanos em todas as áreas: arte, ciência, negócios e cultura. ${ }^{61}$

Essa forma interativa e coletiva de comunicação fortalece o que Pierre Lévy denomina como "inteligência coletiva", ou seja, a capacidade de grupos de pessoas com interesses comuns desenvolverem reflexões e até produzirem uma mensagem, seja qual for o meio, em conjunto. Nas palavras do autor, "o ciberespaço como suporte da inteligência coletiva é uma das principais condições de seu próprio desenvolvimento" ${ }^{62}$. E ainda, "devido a seu aspecto participativo, socializante, descompartimentalizante, emancipador, a inteligência coletiva proposta pela cibercultura constitui um dos melhores remédios para o ritmo desestabilizante, por vezes excludente, da mutação técnica"63. A inteligência coletiva é o preanúncio das possibilidades de democratizar a pesquisa, o conhecimento e a produção, ou seja, de exaltar as manifestações sociais de um grupo de indivíduos com interesse em comum.

Às formas de comunicação tradicionais (rádio, cinema, televisão, impressos, etc.) se atribuem o mesmo caráter participativo e democratizante da disseminação do conhecimento e informação (mesmo que com objetivos do lucro dos produtores), mas não da produção. Nisso entendemos que a produção comunicativa está limitada ao interesse da massa, público alvo dos meios midiáticos, e dos produtores. Mas está longe das possibilidades participativas no processo de concepção e produção do conjunto meio-mensagem que a inteligência coletiva, fomentada pela cibercultura, permite.

A inteligência coletiva só é eficientemente apropriada no contexto ciberespacial pelo caráter comunicativo que se encontra na rede das redes (Internet) mediada por computador. Lévy ilustra muito bem os conceitos midiáticos que envolvem os meios de comunicação vigentes:

Podemos distinguir três grandes categorias de dispositivos comunicacionais: um-todos, um-um e todos-todos. A imprensa, o rádio e a televisão são estruturados de acordo com o princípio um-todos: um centro emissor envia suas mensagens a um grande número de receptores passivos e dispersos.

${ }^{61}$ SANTAELLA, Lúcia. Navegar no ciberespaço: o perfil cognitivo do leitor imersivo. São Paulo: Paulus, 2004, p. 40.

${ }^{62}$ LÉVY, Pierre. Cibercultura. São Paulo: Ed. 34, 1999, p. 29.

${ }^{63}$ Ibidem, p. 30. 
O correio ou o telefone organizam relações recíprocas entre interlocutores, mas apenas para contatos de indivíduo a indivíduo ou ponto a ponto. $\mathrm{O}$ ciberespaço torna disponível um dispositivo comunicacional original, já que ele permite que comunidades constituam de forma progressiva e de maneira cooperativa um contexto comum (dispositivo todos-todos) ${ }^{64}$.

Sobre isso, o artista multimídia e professor Gilbertto Prado ${ }^{65}$ defende a rede como um meio de experimentação já que se trata de "um canal de comunicação aberto" onde existe "uma enorme expansão na possibilidade de criação e de exposição, uma vez que ela é de fácil acesso e manuseio e ainda geralmente não há filtro para exibição."Dessa forma, "no que diz respeito à criação, realização e divulgação, a rede se apresenta como um meio facilitador para a experimentação" ${ }^{66}$

Como meio de experimentação criativa e ativa, Prado considera que

as novas possibilidades de relação participante/informação/suporte tecnológico, habilitadas pela tecnologia de comunicação mediada por computadores no ambiente de rede, proporcionam um espaço de comunicação interativo, com experiências de presença e ação a distância e participação em eventos, explorando a sensação de ubiqüidade e simultaneidade. Com base nesses sistemas de percepção mediados por computadores, estamos redescobrindo e reconstruindo nossas relações com o mundo e habituando-nos a conviver de forma crescente com uma enorme quantidade de informação que se distribui em infinitos percursos e interconexões.

A participação interativa em rede nos traz, no mínimo, o sentimento de cidadãos do universo, tendo o planeta se tornando um espaço de referência cotidiano. A vida toma um outro ritmo, assim como a realidade, a cultura e o imaginário que nos rodeiam: estar presente instantaneamente, nesse movimento transpor-se virtualmente no espaço imaginário - campo transformador de potencialidades e no qual todas as trajetórias são possíveis. Por meio das redes podemos ir a todas as direções e já podemos começar a partilhar o espaço virtual com outros que estão em conexão. ${ }^{67}$

Esse "partilhar do espaço" que acontece na rede, abarca todas as três categorias de comunicação colocada por Pierre Lévy, com a ressalva de que "todos" se refere a todos os conectados, e se traduz em qualquer ação do ser conectado. Por exemplo, os blogs são, em sua maioria, produções individuais disponíveis para a consulta de outros internautas mas não modificáveis por eles. Segue a lógica do umtodos em seu conteúdo, mas difere quanto ao seu acesso, pois o usuário tem o

64 Ibidem, p. 63.

${ }^{65}$ Gilberto Prado é professor no Departamento de Artes Plásticas da ECA/USP onde também coordena o grupo acadêmico Poéticas Digitais, onde professores e alunos encontram espaço de experimentação artística e reflexão sobre o impacto das novas tecnologias no mundo das artes.

${ }^{66}$ PRADO, Gilbertto. Arte telemática: dos intercâmbios pontuais aos ambientes virtuais multiusuário. São Paulo: Itaú Cultural, 2003, p. 65.

${ }^{67}$ Ibidem, p. 102. 
poder interator de se conduzir conforme seus interesses e necessidades dada a estruturação da página.

O e-mail, no seu uso mais básico, se vale da lógica um e um, pois como o correio convencional, encaminha as informações de um ponto endereçado (remetente) a outro ponto (destinatário). Por sua possibilidade tecnológica que permite a troca de informações de forma quase instantânea, a Internet permite a criação de chats para troca de mensagens e até troca de imagens de vídeo em tempo quase real com o princípio ponto a ponto. Como as informações podem ser duplicadas sem perda de conteúdo (um dos aspectos essenciais da tecnologia digital), o ponto receptor (destinatário) pode ser instantaneamente multiplicado para vários endereços finais, possibilitando os e-groups e conferências à distância.

Mas de fato o caráter inovador do ciberespaço se encontra na possibilidade de se fazer a comunicação de todos para todos, ou melhor muitos-muitos. Mais uma vez detectamos o discurso perfeitamente cabível da inteligência coletiva como linha de produção social, econômica, política, educacional e artística na plenitude possível da democracia da informação. Nesse sentido, afirma Lévy: “(..) a cibercultura expressa o surgimento de um novo universal, diferente das formas culturais que vieram antes dele no sentido de que ele constrói sobre a indeterminação de um sentido global qualquer"68. Nessa indeterminação é possível estabelecer relações imparciais aos interesses meramente lucrativos das mídias convencionais, relações essas que vão, numa instância mais ideológica, almejar a democratização do conhecimento e da produção comunicativa.

Com a relação todos a todos observa-se a criação de comunidades virtuais onde indivíduos se juntam em torno de um bem comum. Várias páginas de discussão (fóruns) dão espaço para perguntas e respostas que exemplificam a construção da inteligência coletiva quando usuários menos experientes são auxiliados por outros que, por outro lado, são motivados a buscar soluções para o problema de outros. A ajuda mútua produz maior disseminação do conhecimento.

Outros sites oferecem a possibilidade da criação coletiva. São páginas que dão suporte para que pessoas com interesse comum em animação, por exemplo, possam se unir e dividir tarefas (de forma remota) para construírem um curtametragem. Além do mais, novos profissionais ou amadores podem disponibilizar

${ }^{68}$ LÉVY, Pierre. Cibercultura. São Paulo: Ed. 34, 1999, p. 15. 
suas produções audiovisuais, fonográficas, fotográficas, entre outras, para que outros as utilizem (com a obrigação de creditá-las), disseminando seu trabalho. $\mathrm{O}$ crescimento das produções em domínio público só tendem a enriquecer as possibilidades de democratizar a comunicação no ciberespaço.

Mais uma vez Pierre Lévy ressalta a importância da cibercultura no desenvolvimento da inteligência coletiva, no sentido de que

(...) apenas as particularidades técnicas do ciberespaço permitem que os membros de um grupo humano (que podem ser tantos quantos quiser) se coordenem, cooperem, alimentem e consultem uma memória comum, e isto quase em tempo real, apesar da distribuição geográfica e da diferença de horários. O que nos conduz diretamente à virtualização das organizações que, com a ajuda das ferramentas da cibercultura, tornam-se cada vez menos dependentes de lugares determinados, de horários de trabalho fixos e de planejamentos a longo prazo. ${ }^{69}$

$\mathrm{Na}$ mídia convencional, ou seja um-todos, existe a preocupação com a aceitação da recepção já que "uma vez que a mensagem midiática será lida, ouvida, vista por milhares ou milhões de pessoas dispersas, ela é composta de forma a encontrar o "denominador comum" mental de seus destinatários. Ela visa os receptores no mínimo de sua capacidade interpretativa. ${ }^{70 ",}$

No ciberespaço a preocupação não está somente na capacidade interpretativa dos receptores porque simplesmente não há mais meros receptores passivos, e sim inter-atores que recebem e produzem comunicação. Sobre essa produção comunicativa estão se desenvolvendo várias ferramentas para dar suporte à crescente comunidade que se vale de meios audiovisuais e fotográficos, por exemplo, produzindo mais informações.

Paralelamente, Derrick De Kerckhove, em seu ciclo de palestras baseado na sua obra "Connected Intelligence: The Arrival of the Web Society"71, defende que a "inteligência conectiva" promove a importância de considerar o compartilhamento de conhecimentos ao invés do conhecimento como propriedade de um único indivíduo. Dessa forma, é importante salientar o processo de criação de conhecimento que se torna tão importante quanto o próprio conteúdo, pois se trata de realizar a "gestão de

\footnotetext{
69 Ibidem, p. 49.

70 Ibidem, p. 116.

71 DE KERCKHOVE, Derrick. Connected Intelligence: The Arrival of the Web Society. EUA: Somerville House, 1997.
} 
conhecimento" para gerir as relações entre as pessoas, bem como os meios de comunicação que elas utilizam para se comunicar.

Assim, o compartilhamento de conhecimento e informação em rede aumenta dramaticamente a capacidade de conectar inteligências e saberes. Segundo De Kerckhove, ao contrário da recepção passiva da informação obtida através da televisão, rádio e/ou jornal, a internet é um meio altamente interativo e promove o compartilhamento de pensamentos. De fato a instantaneidade no processo de recepção de informação, reelaboração e repasse em tempo quase real, permite que se atinja a velocidade do pensamento. A troca de incontáveis pensamentos leva à inteligência, então, conectiva.

Dessa forma, De Kerckhove salienta a idéia de que a inteligência deve ser entendida como um recurso compartilhado em vez de propriedade exclusiva de um particular. A inteligência está dentro e fora dos indivíduos, mas só se torna pertinente quando compartilhada.

\subsection{2 - Produção da informação no ciberespaço}

Conceitualmente a tecnologia digital permite que informações das mais variadas naturezas possam ser traduzidas para um estado virtual, já que se passa para uma linguagem, constituída de números (e simplificados em 0 e 1), somente legível para computadores e aparelhos eletrônicos. Pierre Lévy explica que:

A informação digital (traduzida para 0 e 1) também pode ser qualificada de virtual na medida em que é inacessível enquanto tal ao ser humano. Só podemos tomar conhecimento direto de sua atualização por meio de alguma forma de exibição. Os códigos de computador, ilegíveis para nós, atualizamse em alguns lugares, agora ou mais tarde, em textos legíveis, imagens visíveis sobre tela ou papel, sons audíveis na atmosfera ${ }^{72}$.

Para entender o conceito de virtual de Pierre Lévy, é necessário compreender que "em filosofia o virtual não se opõe ao real, mas sim ao atual: virtualidade e atualidade são apenas dois modos diferentes da realidade. Se a produção da árvore está na essência do grão, então a virtualidade da árvore é bastante real (sem que seja, ainda, atual) $)^{373}$.

\footnotetext{
${ }^{72}$ LÉVY, Pierre. Cibercultura. São Paulo: Ed. 34, 1999, p. 48.

${ }^{73}$ Ibidem, p. 47.
} 
Desse modo, a informação virtualizada em 0 e 1 é real, ou seja, a informação não deixa de existir por não ser legível aos homens (é como se passasse a estar codificada no DNA do grão de uma árvore). A informação digital é real, mas não atual, sendo que só passará para essa condição após sua tradução através de um computador e/ou aparelho eletrônico com a configuração apta para essa tradução. De qualquer forma, a informação está impressa (materializada, mesmo que magneticamente) em alguma plataforma, seja no disco rígido de um computador, em um disquete ou um $C D$, o que mostra que o virtual existe na condição de existir uma base material e, portanto, não é contrário ao real. Mesmo a informação contida no tecido cerebral humano depende de ligações bioquímicas (sinapses), que são materiais. A informação de uma dor, por exemplo, se vale dessa base material para encaminhar a corrente elétrica que se atualizará em sensações e manifestações de sofrimento.

$\mathrm{Na}$ questão da tecnologia digital para a produção audiovisual é possível afirmar que "qualquer imagem ou seqüência de imagens é portanto traduzível em uma série de números. Um som também pode ser digitalizado se for feita uma amostragem, ou seja, se forem tiradas medidas em intervalos regulares" ${ }^{74}$. Exemplificando dessa forma, Pierre Lévy comprova que as informações podem ser digitalizadas e, então armazenadas e copiadas sem perda de dados, pois "a informação digitalizada pode ser processada automaticamente, com um grau de precisão quase absoluto, muito rapidamente e em grande escala quantitativa"75.

A tecnologia digital se extende ao processo de trabalho sobre a informação onde, por exemplo, imagens podem ser tratadas em suas cores, saturações de luzes, efeitos, retoques etc. $O$ áudio pode ser alterado por registros de freqüência, é possível reduzir ruídos, adicionar efeitos. E toda modificação com tecnologia digital é de fácil acesso e aprendizado, e isso "é porque as informações estão codificadas como números que podemos manipulá-las com tamanha facilidade: os números estão sujeitos a cálculos, e computadores calculam rápido"76.

No ápice da tecnologia digital voltada para os recursos audiovisuais estão, segundo o autor,

\footnotetext{
${ }_{75}^{74}$ lbidem, p. 50.

${ }^{75}$ Ibidem, p. 52.

${ }^{76}$ Ibidem, p. 53.
} 
filmes digitais que não provêm do tratamento de uma imagem desenhada à mão ou captada por uma câmera, mas de modelos geométricos dos volumes a serem representados, das leis de refração da luz, de funções que descrevem os movimentos dos personagens ou da câmera virtual etc. Programas de síntese, incorporando modelos formais dos objetos a seres simulados, fazem com que os computadores calculem sons ou imagens ${ }^{77}$.

A possibilidade de se recriar espaços conhecidos ou imaginados pelo homem com alta fidelidade e aceitação tornam as tecnologias digitais instrumentos para a "realidade virtual", ou seja, um ambiente simulado que, com tecnologia de recepção e interação (óculos tridimensionais, luvas com sensibilidade tácteis, fones surround etc.) e com as facilidades de viagem informacional do ciberespaço, já que se tratam de dados digitais, promovem a integração de vários indivíduos em um ambiente único que interagem em ação e reação quase de forma natural. Assim, "o computador, então, não é apenas uma ferramenta a mais para a produção de textos, sons e imagens, é antes de mais nada um operador de virtualização da informação ${ }^{78}$ ". Informação que pode chegar à simulação de ambientes e de cenários. Sobre as novas tecnologias que surgem na sociedade da informação, Derrick Kerchkhove afirma que

... não só prolongam as propriedades de envio e recepção da consciência, como penetram e modificam a consciência dos seus utilizadores. A realidade virtual ainda está mais ajustada a nós. Acrescenta o tacto à visão e audição e está mais próxima de revestir totalmente o sistema nervoso humano do que alguma tecnologia até hoje o fez. Com a realidade virtual e a tele-presença permitida pela robótica projetamos literalmente para o exterior a nossa consciência e vemo-la 'objetivamente'. Esta é a primeira vez que o homem o consegue fazer. (...) Com efeito, a característica essencial, a interação, a capacidade que garante a nossa autonomia individual dentro da poderosa tendência da coletivização psicotecnológica, é fornecida pelos computadores e ainda mais eficazmente pelas redes de computadores" ${ }^{\prime 79}$

Em comparação às mídias tradicionais, por mais que essas migrem para o formato digital e promovam a convergência dos multimeios comunicativos, as realidades virtuais se destacam por provocar o estímulo em vários sistemas perceptivos humanos. Segundo Pierre Lévy,

A recepção de uma mensagem pode colocar em jogo diversas modalidades perceptivas. O impresso coloca em jogo sobretudo a visão, em segundo lugar o tato. Desde que o cinema é falado, ele envolve dois sentidos: visão

\footnotetext{
${ }_{78}^{7}$ Ibidem, p. 53.

${ }_{79}^{7}$ Ibidem, p. 55.

${ }^{79}$ KERCHKHOVE, D. A pele da cultura. Lisboa, Portugal: Relógio D’Água, 1997, p.34.
} 
e audição. As realidade virtuais podem colocar em jogo a visão, audição, o tato e a cinestesia (sentido interno dos movimentos do corpo) ${ }^{80}$.

E além de provocar os órgãos sensoriais, Gilbertto Prado defende que

O campo da realidade virtual promete importantes desenvolvimentos, notadamente uma vez que as máquinas são ligadas em rede, oferecendo a possibilidade de imersão, de ação sobre as imagens, sobre objetos virtuais, sobre os nossos próprios avatares e os de nossos vizinhos. Esses desenvolvimentos aportam certamente profundas modificações, que já podemos entrever com a explosão de imagens sintéticas e com a chegada dos mundos virtuais multiusuário. Mundos onde os participantes poderão, por meio de seus avatares, partilhar ambientes, interagir, intervir e construir no ciberespaço. ${ }^{81}$

Tal potencial de participação, imersão e construção do ciberespaço se potencializa pela característica básica da tecnologia digital de se promover uma comunicação mais eficiente através de formas mais acessíveis de produzir uma mensagem (captura e manipulação de informações digitais) e de distribuir essa mensagem sem perda de recursos e nem de dados da informação (pela Internet), para um público infinito (em quantidade e no tempo).

A tecnologia digital, então, inaugura a hipermídia que, como define a professora Santealla, "mescla textos, imagens fixas e animadas, vídeos, sons, ruídos em um todo complexo. É essa mescla de vários setores tecnológicos e várias mídias anteriormente separadas e agora convergentes em um único aparelho, o computador, que é comumente referida como convergência das mídias." ${ }^{82}$ e vai além, com a promoção do hipertexto, definido como a

(...) capacidade de armazenar informação e, por meio da interação do receptor, transmutar-se em incontáveis versões virtuais que vão brotando na medida mesma em que o receptor se coloca em posição de co-autor. Isso só é possível devido à estrutura de caráter hiper, não seqüencial, multidimensional que dá suporte às infinitas opções de um leitor imersivo. ${ }^{83}$

Ao, então, receptor, cabe interagir ativamente com a informação para escrever a mensagem recebida segundo as suas necessidades e desejos de profundidade e conexões. Nesse sentido,

O leitor não pode usá-la de modo reativo ou passivo. Ao final de cada página ou tela, é preciso escolher para onde seguir. É o usuário que

${ }^{80}$ LÉVY, Pierre. Cibercultura. São Paulo: Ed. 34, 1999, p. 64.

${ }^{81}$ PRADO, Gilberto. Arte telemática: dos intercâmbios pontuais aos ambientes virtuais multiusuários. São Paulo: Itaú Cultural, 2003, p. 102.

${ }^{82}$ SANTAELLA, Lúcia. Navegar no ciberespaço: o perfil cognitivo do leitor imersivo. São Paulo: Paulus, 2004, p. 48.

${ }^{83}$ Ibidem, p. 49. 
determina qual informação deve ser vista, em que seqüência ela deve ser vista e por quanto tempo. Quanto maior a interatividade, mais profunda será a experiência de imersão do leitor, imersão que se expressa na sua concentração, atenção, compreensão da informação e na sua interação instantânea e contínua com a volatilidade dos estímulos. O desenho da interface é feito para incentivar a determinação e a tomada de decisão por parte do usuário. Isso significa que a interatividade em um sistema informacional dá ao receptor alguma influência sobre o acesso à informação e um grau de controle sobre os resultados a serem obtidos. ${ }^{84}$

Sendo a interatividade entre leitor e mensagem essencial para ocorrer a atualização das informações,

\begin{abstract}
Nesse novo contexto, o emissor não emite mais mensagens, mas constrói um sistema com rotas de navegação e conexões. A mensagem passa a ser um programa interativo que se define pela maneira como é consultado, de modo que a mensagem se modifica na medida em que atende às solicitações daquele que manipula o programa. Essas manipulações se processam por meio de uma tela interativa ou interface que é lugar e meio para o diálogo. Por intermédio de instrumentos materiais (tela, mouse, teclado) e imateriais (linguagem de comando), o receptor transforma-se em usuário e organiza sua navegação como quiser em um campo de possibilidades cujas proporções são suficientemente grandes para dar a impressão de infinitude. Os programas interativos ainda oferecem ao navegador a possibilidade de mudar de identidade e de papel numa multiplicidade de pontos de vista. Os programas são formas de elaborar pensamentos e levam o usuário a incorporar identidades geradas no ciberespaço. ${ }^{85}$
\end{abstract}

Novamente aqui, se inviabiliza o fluxo comunicativo tradicional emissormensagem-receptor para uma relação de autoria e co-autoria através da interatividade promovida pelas tecnologias digitais de comunicação. Mais do que nunca, o campo comunicativo se torna um ambiente, um espaço (ciberespaço) para a promoção de trocas e relacionamentos informativos e sociais.

Este capítulo, portanto, está baseado nos predicados teóricos de que o homem dialoga com a tecnologia no momento em que a elabora para a sua sobrevivência e que, ao mesmo tempo em que a desenvolve, também tem a sua formação condicionada pela potencialização oferecida por esta. No contexto tecnológico da comunicação digital várias potencialidades se abrem para a formação do homem digital tanto no sentido dos novos paradigmas e valores éticos da sociedade em rede, quanto ao processo de formação dos nativos digitais. Estas questões serão abordadas no capítulo seguinte.

\footnotetext{
84 Ibidem, p. 52.

${ }^{85}$ Ibidem, p. 163.
} 


\section{CAPÍTULO 2 - Tecno-pedagogia: a formação lúdica do homem tecnológico}

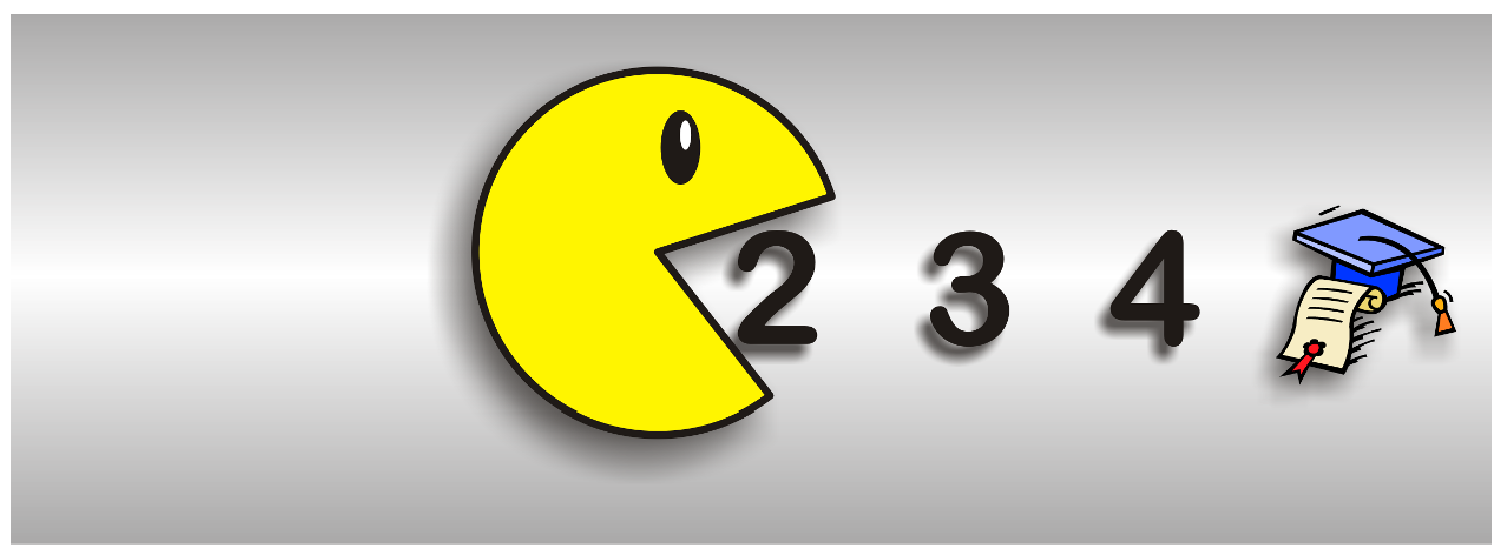




\section{CAPÍTULO 2 - Tecno-pedagogia: a formação lúdica do homem tecnológico}

\section{Introdução ao capítulo}

No capítulo anterior foram desenvolvidos alguns conceitos teóricos acerca da relação dialógica entre homem e tecnologia e como o homem se constrói pelas possibilidades tecnológicas digitais. Nesse capítulo, também teórico, a dissetação pretende aprofundar nas questões dessa relação tecnologia digital e homem, no viés da sua formação, defendendo que o processo pedagógico do ser digital é mais eficiente quando contém o elemento lúdico e que a interação entre o homem e a técnica já traz consigo o sentimento de realização.

De fato, cada vez mais se compreende que a ludicidade, ou o prazer e o jogo no ato de fazer, é o elo mais coerente e permanente entre ensino e aprendizagem. Informações, lógicas, raciocínios e valores são apropriados de forma mais profunda e inerente quando são assimilados de forma prazerosa e condicionada em jogo, ou seja de forma lúdica. Brincar de casinha tem fundamental papel na formação da criança na identificação das responsabilidades e deveres da vida adulta, como analisa o casal Singer (2007) ${ }^{1}$.

Ao transpor para o brincar digital, por meio dos jogos eletrônicos, a validade da relação educação-ludicidade se mantém e resulta na formação da criança. Nesse sentido, o brincar físico, ou - no senso comum - brincar "real", não se difere ao brincar informativo-codificado (mediado por plataformas eletrônicas, como o computador ou o videogame), ou - no senso comum - brincar "virtual".

\footnotetext{
${ }^{1}$ SINGER, Dorothy G. \& SINGER, Jerome L. Imaginação e jogos na era eletrônica. Porto Alegre: Ed. Artmed-Bookman, 2007.
} 


\title{
2.1 - Do teatro grego: um partido clássico para uma nova abordagem sobre a formação pelo lúdico e tecnológico
}

\begin{abstract}
Levanto-me antes do próprio sol vir brindar o vale. Como bom cidadão, não posso faltar aos meus deveres... e quem pode se queixar de se levantar antes da luz do dia para mais um dia de vida política? Logo, deixando meu lar, me junto a tantos outros cidadãos dignos e notáveis numa caminhada rotineira até a colina que beira o penhasco.

Acomodo-me nos degraus do theatron ao lado dos meus iguais para, em mais uma manhã, ressaltar as emoções e celebrar a vida cheia de atribulações, derrotas e tristezas, mas, também, cheia de conquistas, poesia e filosofia. Vida concedida pelos deuses, que simplesmente assistem o mundo dos homens.

A começar pela arena onde nos assentamos, o ideal da democracia grega da polis é exalada pela arquitetura que, pelas pedras em anéis, desenham um espaço onde qualquer cidadão, de qualquer lugar tem o mesmo acesso visual e sonoro do espetáculo. E mesmo antes do espetáculo a alma se enche pelo presente infinito e divino da paisagem do horizonte. O teatro, pela sua constituição espacial, parece simplesmente pontuar a infinidade do universo. Pelo espetáculo, o teatro também pontua os vários ensinamentos dos deuses para as nossas quase insignificantes vidas.
\end{abstract}

Como não chorar diante da tragédia desses deuses, semi-deuses e homens que tecem suas vidas heróicas em meio ao sacrifício e à dor? Como não rir da piada onde a nossa própria vida encontra caminho? Como não redescobrir a identidade, valores e sonhos de um verdadeiro grego quando este, no meio dos seus irmãos congregados, se depara com o espetáculo da vida grega?

Antecipando a mistura de sentimentos e pensamentos que certamente me atordoarão nessa manhã, eu foco meus olhos no skene, onde, por conta da mechané, surgirá algum ator a declarar o epílogo da primeira tragédia. Ansiosamente, aguardo que a orchestra se encha com o coro a dramatizar, em canto e dança, os versos e odes da voz coletiva.

Tenho clara consciência da racionalidade que atravessa a engenharia por trás das construções dos espaços e da peça. Mas quando a razão se funde à alma, é 
impossível não se render às emoções. O ápice, ao final da peça, é exemplo da técnica que vai além da razão e que toca e comove qualquer mente a se fundir com a alma. O ápice está na apó mechanés theós ${ }^{2}$, ou seja, a aparição de deus pela máquina. $O$ efeito é imediato e atordoante. A tecnologia de guindaste, cordas e roldanas é absorvida e desaparece no momento de realidade fictícia criada na emocionante aparição do deus salvador.

Com a aparição do protagonista, deuteragonista e do tritagonista, todos mergulhados em panos e trajando máscaras de gesso, me lembro que a vida é feita de camadas de ordem, de poder e de máscaras. Nesse sentido, as invenções e exageros do teatro apresentam mais autenticidade e realidade do que as aparências da vida vivida.

Vários temas podem ser ilustrados a partir do teatro grego, pois o espetáculo cênico clássico destaca, por exemplo, aspectos da cidadania "democrática" da polis, ao mesmo tempo em que ressalta o machismo da sociedade (somente os homens eram considerados cidadãos). Pode-se discutir, como outro exemplo, a universalização da cultura clássica, já que o teatro grego definiu a concepção de artes cênicas que perdura até a contemporaneidade. Essa pesquisa opta por destacar alguns aspectos não tão tradicionais como pontos de partida para as discussões a serem desenvolvidas. Todos os aspectos técnicos, formais, poéticos, cenográficos e estruturais são encontrados em autores como Brandão ${ }^{3}$ e Lannes ${ }^{4}$.

Do contexto teatral clássico é possível destacar, por exemplo, a tecnologia envolvida para a constituição física, estrutural, arquitetônica e cênica das grandes arenas. A partir da criteriosa escolha do ponto geográfico, onde o próprio Sol desempenhava um papel cenográfico de inspiração quase divina, os patamares de pedra recortada e alinhada desenham um espaço em que a imagem e o som da encenação podiam ser recebidos por qualquer espectador, com qualidade semelhante e, portanto, sem hierarquias definidas.

De forma muito engenhosa, a mechané, grua constituída de polias, cordas e engrenagens, suspendiam os atores até o skene, o palco dos heróis e protagonistas. Desse palco suspenso, se construía um jogo de versos com os cantos do coro que,

\footnotetext{
2 "apó mechanés theós" em grego, ou "deus ex machina" em latim,

${ }^{3}$ BRANDÃO, Junito de Souza. Teatro grego: origem e evolução. São Paulo: Ars Poética, 1992.

${ }^{4}$ LANNES, Osmar Perazzo. Teatro grego. São Paulo: Ed. Paumape, 1993.
} 
em música e em dança, dialogavam com os atores. Obras de Ésquilo e Sófocles, bem como as comédias de Aristófanes, foram interpretadas em meio a tanto engenho técnico.

O exemplo mais claro da engenharia tecnológica empregada está na aparição final de um deus, ou entidade heróica, representada por um boneco que surge monumentalmente através de sistema de guindaste, cordas e polias. Tal aparição final passaria a ser conhecida por "apó mechanés theós", em grego, "deus ex machina", em latim, ou "deus surgido da máquina", em uma tradução livre para o português, onde o entretenimento servia para passar os valores religiosos, éticos e políticos para formar a opinião pública dos cidadãos gregos. Sobre isso, Massimo Di Felice escreve que:

Sempre construídos em posição estratégica , geralmente numa colina que se debruçava sobre o mar, todos os teatros gregos apareciam como um lugar irreal, no interior dos quais os elementos narrativos eram acompanhados por diversos efeitos técnicos, como a chegada do "deus ex maquina" ou das intervenções sonoras do coro, mascarado ou invisível, com a finalidade de conduzir o público ao delírio e à comoção.

Encontramos aqui outro elemento fundamental que, desde então, passa a caracterizar a participação dos cidadãos na vida pública, permitindo a divulgação da mensagem e o acesso a ela por um amplo público. Refiro-me ao elemento midiático e aos aspectos tecnológicos que, desde o teatro, transformarão a vida publica, o acesso ao debate e à participação em um fato tecno-comunicativo.

A própria forma arquuitetonica do teatro, que permitia uma visão plena de qualquer ponto, e sua acústica, a qual possibilitava ouvir igualmente de qualquer lugar e a qualquer distancia, demonstram, ao contrario do pensamento comum, como a comunicação, mais que elemento externo, se constitui em fator propiciador que permite realização de troca pública e funda o público enquanto o insere em uma arquitetura comunicativa real. ${ }^{5}$

Então, além do aspecto técnico, o teatro grego tematiza questões pedagógicas. Toda tragédia e comédia eram compostas para passar valores. Desde a afirmação das crenças sobre o divino, até educação moral, cívica e familiar (as relações e ações de Édipo exemplificam o componente pedagógico do teatro grego). Os espetáculos eram elaborados de forma a encantar pela poesia, música, dança, cenário e figurino, ao mesmo tempo em que serviam de doutrinação e educação. Era parte, também da educação formal do cidadão grego, pois o coro era formado por jovens que estavam se preparando para o serviço militar, e que, por conta do teatro,

${ }^{5}$ DI FELICE, Massimo. "Das tecnologias da democracia para as tecnologias da colaboração" in DI FELICE, Massimo (org.). Do público para as redes: a comunicação digital e as novas formas de participação social. São Caetano do Sul, SP: Difusão Editora, 2008, p. 19. 
aprimoravam suas capacidades artísticas antes de se doutrinarem na inteligência bélica.

Essa educação pelo espetáculo acontecia por conta de todos os elementos lúdicos presentes no teatro grego. A atividade prazerosa, ou lúdica, de apreciar tragédias e comédias gregas, estava além do aflorar das emoções, na simpatia às histórias e protagonistas. O prazer se encontrava, também, na identificação, na empatia. E na dicotomia em que se aproxima o espetáculo ao cotidiano, o grande ao pequeno, o heróico ao ordinário, faz-se um paralelo em aproximar a virtude ao comum, o virtual ao real. Em outras palavras, o teatro grego considera a virtualidade mitológica e teatral como uma atribuição da realidade social, o que promove a discussão sobre as "realidades virtuais" no cotidiano em que real e virtual não se confrontam, mas co-existem no habitar e no aprender do ser humano.

Com a proposta de discorrer sobre os aspectos lúdicos que se encontram na convergência entre tecnologia digital e educação, este capítulo procura desenvolver as questões identificadas no teatro grego, fazendo paralelos teóricos, filosóficos e práticos sobre a tecno-pedagogia (termo decorrente da "tecnopsicologia", ou "psicotecnologia" de Derrick De Kerckhove ${ }^{6}$ ).

Primeiramente, a técnica empregada na construção arquitetônica dos teatros tem um paralelo na construção mútua entre sociedade e tecnologia. Os gregos construíam os teatros, mas os teatros construíam a sociedade grega. Observando as grandes evoluções tecnológicas, percebe-se que as sociedades desenvolveram as tecnologias que, por sua vez, desenvolveram os próprios modos de ser e estar (habitar) da sociedade e de seus integrantes. Não é possível considerar somente um uso instrumental da tecnologia, mas é necessário identificar como a tecnologia interfere, modifica, potencializa e contamina/ contagia o habitar do ser humano. $O$ homem constrói a tecnologia e é construído por ela, em uma relação dialógica e não antropocêntrica.

Pode-se verificar esse desenvolvimento mútuo entre homem e tecnologia ao considerar que a tecnologia da escrita possibilitou a memória científica e difusão transcultural, e que a tecnologia da imprensa permitiu a disseminação políticoideológica de um momento social histórico. Ao mesmo tempo, é possível considerar que a tecnologia da energia a vapor deu início à virtualização do tempo e espaço,

${ }^{6}$ DE KERCKHOVE, Derrick. A pele da cultura. Lisboa: Ed. Relógio D’Água, 1997. 
relativizando as distâncias e tempo do trabalho, e que a tecnologia eletrônica estendeu os potenciais perceptivos do ser humano, por meio dos meios de comunicação (como já defendia McLuhan, em 19647).

Nesse sentido, a formação do homem (pelas práticas pedagógicas) pode, ao longo da história, ser identificada pela sua relação com a tecnologia, que sempre existiu. Considerando além da educação formal e institucionalizada nas escolas, que empregam a tecnologia das salas, carteiras, lousa, oratória, biblioteca, etc., é possível apontar que, na educação informal desenvolvidas nas experiências da vida, todo ser humano é envolto por várias tecnologias e é, por elas, construído. Desde a agropecuária e a pesca até as engrenagens do sistema financeiro, as tecnologias moldam a produção do homem e permitem a sua sobrevivência. Em paralelo semelhante, a tecnologia de uma boneca de pano promove a ludicidade, pelo próprio "brincar", e educação, através da identificação e construção de identidades, com o mesmo potencial que acontece com avatares em um jogo de computador.

\section{2 - O homem e a ludicidade}

Partindo do pressuposto de que a interação com a técnica remete a experiências lúdicas, é importante compreender as dimensões da ludicidade na existência humana. É comum que se limite o lúdico como experiência infantil, voltando sempre para as questões de diversão e brincadeira. Johan Huizinga ${ }^{8}$ desenvolve um novo olhar sobre o lúdico propondo que o homem, ou melhor, "homo ludens" existe e convive com seus semelhantes através de práticas claramente lúdicas. Faz-se necessário, então, conhecer as suas considerações sobre a ludicidade.

Etimologicamente, o lúdico compreende um sentido que vai para o além do plano físico, presencial e temporal. Parece que, então, se aproxima de experiências no plano abstrato e virtual, pois "embora ludere possa ser usado para designar os saltos dos peixes, o esvoaçar dos pássaros o borbulhar das águas, sua etimologia não parece residir na esfera do movimento rápido, e sim a da não-seriedade, e

\footnotetext{
${ }^{7}$ MACLUHAN, Marshall. Os meios de comunicação como extensões do homem. São Paulo: Cultrix , 1964.

${ }^{8}$ HUIZINGA, Johan. Homo ludens. São Paulo: Perspectiva, 2007. 5ª Ed.
} 
particularmente na da 'ilusão' e da ' simulação'."' Ou seja, o lúdico não está ligado ao mundo material, mas para além.

De fato, Huizinga defende claramente a idéia de que o jogo não é uma necessidade básica para a sobrevivência física do homem, mas faz parte e é conseqüência de uma condição que vai além da racionalidade para um campo de prazer e satisfação, pois

No jogo existe alguma coisa "em jogo" que transcende as necessidades imediatas da vida e confere sentido à ação (...) A intensidade do jogo e seu poder de fascinação não podem ser explicados por análises biológicas. E, contudo, é nessa intensidade, nessa fascinação, nessa capacidade de excitar que reside a própria essência e a característica primordial do jogo. ${ }^{10}$

De uma certa forma, Huizinga confere ao homem uma condição "pós-racional", pois tem consciência da própria não-racionalidade do lúdico que abraça e se dispõe e se dedica a experimená-lo. É como se os animais estivessem no plano irracional, e os humanos no plano racional e além (plano "supralógico"), onde o jogo confere ao homem um teor irracional, ou melhor, pós-racional, refinando um pouco mais o termos do autor. Huizing enfatiza isso quando afirma que

A própria existência do jogo é uma confirmação permanente da natureza supralógica da situação humana. Se os animais são capazes de brincar, é porque são alguma coisa mais do que simples seres mecânicos. Se brincamos e jogamos, e temos consciência disso, é porque somos mais do que simples seres racionais, pois o jogo é irracional. ${ }^{11}$

É justamente neste plano supralógico e pós-racional que, aliado à tecnologia verbal, o homem alcança o abstrato e todas as suas derivações no campo do imaginário e da arte. O lúdico completa e complementa o físico e o racional do homem, pois, segundo McLuhan "Na graça e na brincadeira recuperamos a pessoa integral, já que só podemos utilizar uma pequena parcela de nosso ser no mundo do trabalho ou na vida profissional. ${ }^{.12}$ Além disso, para MacLuhan,

os jogos são artes populares, reações coletivas e sociais às principais tendências e ações de qualquer cultura. Como as instituições, os jogos são extensões do homem social e do corpo político, como as tecnologias são extensões do organismo animal. Tanto os jogos como as tecnologias são contra-irritantes ou meios de ajustamento às pressões e tensões das ações especializadas de qualquer grupo social. Como extensões da resposta popular às tensões do trabalho, os jogos são modelos fiéis de uma cultura.

\footnotetext{
${ }^{9}$ Ibidem, p. 41.

${ }^{10}$ Ibidem, p. 4 e 5.

${ }^{11}$ HUIZINGA, Johan. Homo ludens. São Paulo: Perspectiva, 2007. 5a Ed. p. 6

${ }^{12}$ MCLUHAN, Marshall. Os meios de comunicação como extensões do homem. Rio de São Paulo: Editora Cultrix, 1964, p. 264.
} 
Incorporam tanto a ação como a reação de populações inteiras numa única imagem dinâmica. ${ }^{13}$

E se estendendo fisicamente, socialmente e pós-racionalmente, ao homem passa a ser possível alcançar o virtual, ou seja, a maximização e extensão da própria realidade e da expressão da vida, pois

na criação da fala e da linguagem, brincando com essa maravilhosa faculdade de designar, e como se o espírito estivesse constantemente saltando entre a matéria e as coisas pensadas. Por detrás de toda expressão abstrata se oculta uma metáfora, e toda metáfora é jogo de palavras. Assim, ao dar expressão à vida, o homem cria um outro mundo, um mundo poético, ao lado do da natureza. ${ }^{14}$

Aprofundando a questão do abstrato, Huizinga compreende que o homem alcança a virtualidade não no sentido de se opor ao mundo real, mas no sentido de se descolar do plano material, físico e temporal para estender a vida para um outro plano, livre e autônomo e que amplifica as suas experiências e oferece um sentido além da subsistência biológica. $O$ autor passa a defender os elementos do lúdico que permitem ao homem alcançar o plano do abstrato, pois afirma que a primeira característica do jogo é o fato de "ser livre, de ser ele próprio liberdade"15. Uma conseqüência natural dessa característica e "intimamente ligada à primeira, é que o jogo não é vida 'corrente' nem vida 'real'. Pelo contrário, trata-se de uma evasão da vida 'real' para uma esfera temporária de atividade com orientação própria" 16

McLuhan também concorda na condição artificial da ludicidade, onde os envolvidos aceitam participar de um ambiente fictício. Mas o jogo promove comunicação e, por conseqüência, interação e relacionamento estendendo as experiências do ser e dando sentido aos seus comportamentos. Isso, porque

Como nossos idiomas vernáculos, todos os jogos são meios de comunicação interpessoal e podiam não possuir existência nem significado a não ser como extensões de nossas vidas interiores imediatas. Se tomamos uma raquete de tênis, ou 13 cartas de baralho, consentimos em ser parte de um mecanismo dinâmico numa situação deliberadamente artificial. $^{17}$

Dessa forma, o lúdico, por estar tão arraigado na existência e experimentação do homem, deixa de simplesmente satisfazê-lo como algo além das necessidades

\footnotetext{
${ }^{13}$ Ibidem, p. 264.

${ }^{14}$ HUIZINGA, Johan. Homo ludens. São Paulo: Perspectiva, 2007. 5a Ed. p. 7

${ }^{15}$ Ibidem, p. 11

${ }^{16}$ Ibidem, p. 11
} 
biológicas para, ao alcançar o imaginário, ser essencial na produção de sentidos e motivação para o habitar do homem. Ou seja, passa a ser tão necessário para a mente quanto o alimento e proteção são essenciais para o corpo. Isso porque

\begin{abstract}
ele (o jogo) se insinua como atividade temporária que tem uma finalidade autônoma e se realiza tendo em vista uma satisfação que consiste nessa própria realização. É pelo assim que, em primeira instância, o ele se apresenta: como um intervalo em nossa vida cotidiana. Todavia, em sua qualidade de distensão regularmente verificada, ele se torna um acompanhamento, um complemento e, em ultima análise, uma parte integrante da vida em geral. Ornamenta a vida, ampliando-a, e nessa medida, torna-se uma necessidade tanto para o indivíduo, como função vital quanto para a sociedade, devido ao sentido que encerra, à sua significação a todo o tipo de ideais comunitários. Nesta medida, situa-se numa esfera superior aos processos estritamente biológicos de alimentação, reprodução e autoconservação. ${ }^{18}$
\end{abstract}

Soma-se aos aspectos emocionais a promoção social permitida pelo lúdico.

Sobre isso, McLuhan compreende que "os jogos como formas artísticas populares oferecem a todos um meio imediato de participação na vida plena de uma sociedade - coisa que nenhum papel ou emprego isolados podem oferecer a nenhum homem."19 Isso porque,

o jogo é uma máquina que começa a funcionar só a partir do momento em que os participantes consentem em se transformar em bonecos temporariamente. Para o homem individualista ocidental, muito de seu "ajustamento" à sociedade tem o caráter de uma rendição pessoal aos imperativos coletivos. Nosso jogos nos auxiliam tanto a aprender esta espécie de ajustamento como a nos libertar dele. ${ }^{20}$

Apesar de ter um contexto livre e promover liberdade, o lúdico exige regras e ordem que são construídas livremente mas que são necessárias para constituir o próprio jogo. E essa ordem livre é ponto de amplificação e equilíbrio de uma realidade caótica. O lúdico passa a ser referência e uma linha-guia paralela ao plano real, pois

reina dentro do domínio do jogo uma ordem específica e absoluta (...): ele cria ordem e é ordem. Introduz na confusão da vida e na imperfeição do mundo uma perfeição temporária e limitada, exige uma ordem suprema a absoluta: a menor desobediência a esta 'estraga o jogo', privando-o de seu caráter próprio e de todo e qualquer valor. ${ }^{21}$

${ }^{17}$ MCLUHAN, Marshall. Os meios de comunicação como extensões do homem. Rio de São Paulo: Editora Cultrix, 1964, p. 266 e 267.

${ }^{18}$ HUIZINGA, Johan. Homo ludens. São Paulo: Perspectiva, 2007. 5a Ed. p. 12

${ }^{19}$ MCLUHAN, Marshall. Os meios de comunicação como extensões do homem. Rio de São Paulo: Editora Cultrix, 1964, p. 267

${ }^{20}$ Ibidem, p. 267 e 268

${ }^{21}$ HUIZINGA, Johan. Homo ludens. São Paulo: Perspectiva, 2007. 5ª Ed. p. 13 
Exatamente nesse caráter de guiar e de dar sentido às coisas, o lúdico permite o estabelecimento de regras e ordens sociais, ou seja, possibilita a formação da cultura e, portanto, do ser social. Isso porque para Huizinga

a cultura surge sob a forma de jogo, que ela e, desde seus primeiros passos, como que 'jogada'. Mesmo as atividades que visam a satisfação imediata das necessidades vitais, como por exemplo a caça, tendem a assumir nas sociedades primitivas uma forma lúdica. A vida social reveste-se de formas suprabiológicas, que lhe conferem uma dignidade superior sob a forma de jogo, e é através deste último que a sociedade exprime sua interpretação da vida e do mundo. ${ }^{22}$

Se a ludicidade permite existência cultural e social do homem, é parte de sua essência e pode ser visto como elemento integrante e integral do seu contexto tecnológico. O lúdico sempre fez parte do homem e não se limite aos tempos da infância, mas sempre o acompanha na sua formação. De fato, McLuhan concorda com o papel extensor e formador do lúdico para o homem e para as sociedades, pois

qualquer jogo, como qualquer meio de informação, é uma extensão do indivíduo ou grupo. O seu efeito sobre o grupo ou sobre o indivíduo se traduz pela reconfiguração daquelas partes do grupo ou do indivíduo que não são prolongadas ou extendidas. Uma obra de arte não tem existência ou função for a dos efeitos que produz sobre os observadores. E a Arte, como os jogos, as artes populares ou qualquer outro meio de comunicação, tem o poder de impor seus próprios pressupostos, reordenando a comunidade humana por meio de novas relações e atitudes. ${ }^{23}$

McLuhan, ainda, acredita que vários aspectos lúdicos estão presentes em todos os momentos da vida, mesmo naqueles em que não necessariamente existe a busca pelo prazer. O que destaca o momento lúdico dos demais é a própria consciência e participação do homem. Como exemplo, McLuhan afirma que

o que desqualifica a guerra como jogo de verdade é provavelmente o que desqualifica também a Bolsa de Valores e o mundo dos negócios - as regras não são suficientemente conhecidas nem aceitas pelos jogadores. Além disso, o público participa em demasia da guerra e dos negócios, assim como numa sociedade de nativos onde não há arte, verdadeiramente, porque todo mundo está empenhado em fazer arte. A arte e os jogos precisam de regras, convenções e espectadores. Precisam manter-se à parte da situação geral como modelos, para que se conserve a qualidade do jogo. "Jogar", na vida como numa roda, implica em interjogar. ${ }^{24}$

22 Ibidem, p. 53.

${ }^{23}$ MCLUHAN, Marshall. Os meios de comunicação como extensões do homem. Rio de São Paulo: Editora Cultrix, 1964, p. 272.

${ }^{24}$ Ibidem, p. 270 
Se para Huizinga e McLuhan o lúdico permite a formação da cultura e do homem, essa pesquisa assume tal postura sobre a ludicidade e pretende compreender como o jogo e a brincadeira estão inexoravelmente atrelados ao processo de formação do homem, ou seja, no seu desenvolvimento pedagógico. Os próximos tópicos pretendem explorar a formação do homem que é tecnológico (como já visto no Capítulo 1) e que sempre necessitou do elemento lúdico para se compreender e se formar tal qual o seu contexto tecnológico.

\section{3 - A ludicidade como contexto de formação do homem}

Considerando que a ludicidade permeia a formação do homem, ou seja, no processo pedagógico do homem, é fundamental aprofundar a discussão sobre o elemento lúdico como contexto tecnológico. Faz-se necessário apontar e dialogar com idéias de teóricos e educadores que discutem sobre o emprego de atividades lúdicas no processo pedagógico e educativo. Ao mesmo tempo se desenvolvem as questões do uso do computador e dos seus recursos multimídias com fins didáticos em sala de aula e em casa.

Vou abrir um parêntese para citar aqui, a colaboração e inspiração que tive em conversas com a minha mãe Liriam Luri Y. Yanaze, pedagoga e doutora em Ciências da Comunicação (ECA-USP).

$\mathrm{Na}$ verdade, essa dissertação nasce como uma iniciativa própria mas que herda muitos elementos dos meus progenitores. Mesmo sendo formado em arquitetura, meus caminhos profissionais sempre se enveredaram para a comunicação, no sentido mais amplo do seu campo de atuação (desde experiências em consultorias até nos meus passos acadêmicos), em grande parte, por influencia e incentivo do meu pai (Mitsuru Higuchi Yanaze). Veio então a questão pedagógica e as suas intersecções com a comunicação provenientes da minha mãe.

E não só em termos teóricos, acadêmicos e profissionais, mas agradeço a eles pelo incentivo ao comprar alguns consoles e games e me mostrar que a educação pode e deve ser divertida e prazerosa (lúdica) para ser eficiente. 
Ao explorar o potencial do aprender no brincar pretende-se apontar as correntes pedagógicas que privilegiam a construção do conhecimento onde o educando desenvolve seu aprendizado a partir das regras da brincadeira/jogo a que está exposto e, em seu ritmo vai aprendendo e se superando conforme adquire e desenvolve mais informações. O modelo tradicional de ensino onde o professor é o detentor do conhecimento e tem a função de "passá-lo" aos alunos pode ser substituído por um ambiente de ensino-aprendizagem onde o professor tem função de facilitador para o educando construir seus conhecimentos. Considerar as atividades lúdicas como contexto de educação é aceitar a possibilidade de explorar a capacidade do educando em aprender através da construção de conhecimento e através dos desafios, castigos e recompensas que existem nos jogos e brincadeiras. As várias definições e descrições sobre o lúdico, a brincadeira e o jogo, apesar de não serem sinônimos e cada uma dessas categorias ter características próprias, acabam resumidamente por convergir e indicar-se como as atividades que elevam o ser humano a um estado de satisfação físico-mental. Dessa forma, é possível listar várias atividades que se encaixam nesse contexto, não se limitando ao público infanto-juvenil.

Existem várias categorias de jogos e brincadeiras que atingem todas as faixas etárias, que vão das brincadeiras imaginárias de criança (polícia e ladrão, por exemplo) até os jogos esportivos (o futebol de fim-de-semana, por exemplo). Tantos outros exemplos poderiam ser citados para ilustrar como a ação lúdica é presente para qualquer ser humano.

No entanto, é necessário lembrar que o público infanto-juvenil tem a característica muito peculiar de conhecer o mundo e construir suas concepções, e que pode se divertir durante o processo de formação e aquisição de informação, tornando a atividade lúdica tão especial. A brincadeira auxilia na construção de um mundo imaginário que dará base à criança para desenvolver significados e sentidos para o mundo em que está inserida.

Numa situação imaginária como a da brincadeira de "faz de conta", ao contrário, a criança é levada a agir num mundo imaginário (o "ônibus" que ela está dirigindo na brincadeira, por exemplo), onde a situação é definida pelo significado estabelecido pela brincadeira (o ônibus, o motorista, os passageiros, etc.) e não pelos elementos reais concretamente presentes (as cadeiras da sala onde ela está brincando de ônibus, as bonecas, etc.). ${ }^{25}$

${ }^{25}$ OLIVEIRA, Marta Kohl de. Vygotsky - aprendizado e desenvolvimento: um processo sóciohistórico. São Paulo: Scipione, 1995. p. 66. 
Dessa forma, o momento lúdico se torna para a criança a ponte entre o sentir o mundo, interpretá-lo e agir. Nesse sentido "o brinquedo provê, assim, uma situação de transição entre a ação da criança com objetos concretos e suas ações com significados." ${ }^{26}$ É com o brinquedo que se começa a desenvolver um relacionamento com o mundo real, pois permite à criança se sensibilizar com o mundo físico, ativando seus sentidos e captando as sensações das reações que acontecem contra suas ações. Sendo um objeto apropriado para as diferentes formas de exploração "no brinquedo a criança comporta-se de forma mais avançada do que nas atividades da vida real e também aprende a separar objeto e significado." ${ }^{27}$

A criança encontra nos jogos, além da diversão, o desafio e a assimilação de regras, castigos (quando perde) e recompensas (quando ganha). $O$ jogo filtra esses aspectos da vida através de contextos imaginativos para provocar a atividade humana. Quando se trata do processo de desenvolvimento do público infanto-juvenil, o jogo permite a transição de imaginação em ação, pois é quando a criança vai ao encontro de suas necessidades "de tempo e de espaço para trabalhar a construção do real pelo exercício da fantasia." ${ }^{28}$ Isso significa que o jogo abre possibilidades para a criança compreender as relações sociais e culturais através de uma narrativa fantasiosa sobre a própria realidade.

A imaginação, ato de conceber hiper-realidades, é uma forma de se compreender e expressar o contexto real na qual o homem está inserido. Ou seja, a imaginação permite que o homem subjetivamente trate da sua realidade. Para a criança a imaginação, incluindo as fantasias reforçadas pelos brinquedos, pode significar a compreensão de si e do mundo, pois "para Vygotsky, a imaginação em ação ou brinquedo é a primeira possibilidade de ação da criança numa esfera cognitiva que the permite ultrapassar a dimensão perceptiva motora do comportamento." ${ }^{29}$

Esse passo exploratório da esfera cognitiva só acontece porque a criança pode, através da imaginação, alcançar um nível de reflexão que vai além das

\footnotetext{
${ }^{26}$ Ibidem. p. 66.

${ }^{27}$ Ibidem. p. 67.

${ }^{28}$ DIAS, Marina Célia Moraes. "Metáfora e pensamento: considerações sobre a importância do jogo na aquisição do conhecimento e implicações para a educação pré-escolar" in: KISHIMOTO, Tizuko M. (org.). Jogo, brinquedo, brincadeira e a educação. São Paulo: Cortez, 2001. p.50.

29 Ibidem. p.51.
} 
sensações e dos reflexos diante dos estímulos do entorno. A imaginação possibilitada pelos jogos e brincadeiras, permite a criação de contextos fictícios que se baseiam na realidade e fazem a criança extrapolar o contato meramente físicocorporal com o mundo para um nível de reflexão sobre os significados. Para brincar de "casinha" a criança deve estar atenta aos papéis e estereótipos dos personagens envolvidos. Aqui a criança já ultrapassou os estímulos dos sentidos para a compreensão de cada gesto dos personagens imaginados.

O concreto passa ter significados e pode, portanto, ganhar uma forma abstrata de representação. A criança só pode alcançar a proposta de abstração da língua e da escrita depois de estabelecer a ponte entre significado e significante. Para tanto, faz-se necessário estabelecer vínculos imaginativos e fantasiosos para se compreender o fictício. Os momentos lúdicos entram como agente facilitador desse processo porque

(...) na criança a imaginação criadora, surge em forma de jogo, instrumento primeiro de pensamento e enfrentamento da realidade. Jogo sensório-motor que se transforma em jogo simbólico, ampliando as possibilidades de ação e compreensão do mundo. O conhecimento deixa de estar preso ao aqui e agora, aos limites da mão, da boca, e do olho e o mundo inteiro pode estar presente dentro do pensamento, uma vez que é possível "imaginá-lo", representá-lo com o gesto no ar, no papel, nos materiais, com os sons, com palavras. ${ }^{30}$

Entendendo que a imaginação é possibilitada para o público infanto-juvenil, através dos momentos lúdicos de jogos e brincadeiras, é fácil entender porque educadores são quase unânimes quanto à valorização de didáticas mais livres e abertas para o uso da ludicidade na escola. A pedagogia que defende 0 construtivismo tem como um dos alicerces os jogos e brincadeiras educativos como forma de socializar os educandos e provocar, através da imaginação, uma sensibilização do abstrato. "Por isso, é preciso resgatar o direito da criança a uma educação que respeite seu processo de construção do pensamento, que lhe permita desenvolver-se nas linguagens expressivas do jogo, do desenho e da música." ${ }^{\text {„1 }}$

Como já foi tratado, a imaginação possibilitada pelos momentos lúdicos provoca na criança a possibilidade de compreender e construir as relações entre concreto e abstrato, entre significantes e significados. Sabendo desse potencial, fazse necessário que cada vez mais se incentive

\footnotetext{
30 Ibidem. p.52.

${ }^{31}$ Ibidem. p.54-55.
} 
(...) a promoção de atividades que favoreçam o envolvimento da criança em brincadeiras, principalmente aquelas que promovem a criação de situações imaginárias, tem nítida função pedagógica. A escola e, particularmente, a pré-escola poderiam se utilizar deliberadamente desse tipo de situações para atuar no processo de desenvolvimento da criança. ${ }^{32}$

A indústria de entretenimento, atenta a essas necessidades, desenvolve vários brinquedos que auxiliam na construção imaginativa da criança. Lojas especializadas em brinquedos ofertam diferentes modalidades de entretenimento para as diferentes faixas etárias. Dentre as várias modalidades alguns produtos se destacam, pois

entendido como recurso que ensina, desenvolve e educa de forma prazerosa, o brinquedo educativo materializa-se no quebra-cabeça, destinado a ensinar formas ou cores, nos brinquedos de tabuleiro que exigem a compreensão de número e das operações matemáticas, nos brinquedos de encaixe, que trabalham noções de seqüência, de tamanho e de forma, nos múltiplos brinquedos e brincadeiras, cuja concepção exigiu um olhar para o desenvolvimento infantil e a materialização da função psicopedagógicas (...). ${ }^{33}$

A ludicidade possibilita, além da imaginação, a construção de conhecimento.

Para se alcançar um contexto imaginativo coerente e, portanto, aceitável, a criança deve dominar a realidade. Para tanto, além de observar, a criança é incentivada a compreender, a questionar e a buscar conhecer mais. Para satisfazer sua brincadeira, a criança vai buscar informações e conhecimento. $O$ esforço não é de um educador em passar conhecimento, mas sim da criança em buscar mais conhecimento. Essa pedagogia construtivista defende que a criança deve construir seus conhecimentos com incentivos de prazer.

O educador se torna, então, em um facilitador desse processo de construção, filtrando, mediando, instruindo e incentivando os educandos. No uso de brinquedos educativos, a sala de aula se torna em um ambiente prazeroso que incentiva a construção do conhecimento. Como no jogo há recompensa (vitória), a criança é estimulada a obter conhecimento para vencer. Do mesmo modo o castigo (derrota) se torna ponto de partida para o desafio de se superar e melhorar.

Quando essas situações lúdicas são

intencionalmente criadas pelo adulto com vistas a estimular certos tipos de aprendizagem, surge a dimensão educativa. Desde que mantidas as

${ }^{32}$ OLIVEIRA, Marta Kohl de. Vygotsky - aprendizado e desenvolvimento: um processo sóciohistórico. São Paulo: Scipione, 1995. p. 67.

${ }^{33}$ KISHIMOTO, Tizuko M. "O jogo e a educação" in: KISHIMOTO, Tizuko M. (org.). Jogo, brinquedo, brincadeira e a educação. São Paulo: Cortez, 2001. p.36. 
condições para a expressão do jogo, ou seja, a ação intencional da criança para brincar, o educador está potencializando as situações de aprendizagem. Utilizar o jogo na educação infantil significa transportar para o campo do ensino-aprendizagem condições para maximinizar a construção do conhecimento, introduzindo as propriedades do lúdico, do prazer, da capacidade de iniciação e ação ativa e motivadora. ${ }^{34}$

Os desafios e satisfações que os jogos propiciam fazem deles atividades com alto índice de aceitação por parte do público infanto-juvenil no contexto escolar, pois

a utilização do jogo potencializa a exploração e a construção do conhecimento, por contar com a motivação interna, típica do lúdico (...). Ao utilizar de modo metafórico a forma lúdica (objeto suporte de brincadeira) para estimular a construção do conhecimento, o brinquedo educativo conquistou espaço definitivo na educação infantil. ${ }^{35}$

Com os jogos as possibilidades de explorar o conteúdo pedagógico se tornam cada vez mais abrangentes e eficientes. Os educandos não são mais adestrados a ficar parados em cadeiras "ouvindo" um adulto falar. Com os jogos as crianças são estimuladas a atuar e interagir a fim de construir seus conhecimentos.

No ambiente escolar vem se explorando os recursos videográficos e televisivos. E esses recursos têm papel fundamental no processo educativo. Não seriam eles suficientes para a construção do conhecimento? É de fato necessário dar um passo rumo ao emprego das atividades lúdicas para o processo educativo?

Uma resposta à pergunta 'Por que brincar?' é que ele garante que o cérebro - e nas crianças quase sempre o corpo - fique estimulado e ativo. Isso, por sua vez, motiva e desafia o participante tanto a dominar o que é familiar quanto a responder ao desconhecido em termos de obter informações, conhecimentos, habilidades e entendimentos. ${ }^{36}$

Não é só em sala de aula que a atividade lúdica tem dimensões de aprendizado e ganho para a criança. Além das conquistas intelectuais, "o brincar ajuda os participantes a desenvolver confiança em si mesmos e em suas capacidades e, em situações sociais, ajuda-os a julgar as muitas variáveis presentes nas interações sociais e a ser empático com os outros." ${ }^{37}$ Nesse sentido, a atividade lúdica pode ser uma experiência social e promove cidadania, quando aplicada em sala de aula de forma coletiva.

\footnotetext{
${ }^{34}$ Ibidem. p.36-37.

${ }^{35}$ Ibidem. p.37-38.

${ }^{36}$ MOYLES, Janet R. Só brincar? O papel do brincar na educação infantil. Porto Alegre: Artmed, 2002. p.20.

${ }^{37}$ Ibidem. p.22.
} 
É certo que grande parte dos brinquedos comerciais possibilitam a brincadeira individual e, portanto não incentivam a sociabilidade. Já que o momento coletivo é cada vez mais escasso para o universo infanto-juvenil (talvez por causa da insegurança das ruas), muitos brinquedos não são fabricados pensando no coletivo. E mesmo os jogos e brinquedos individuais, por mais que não tenham o caráter de construção coletiva, têm seu valor pois "o brincar oferece situações em que as habilidades podem ser praticadas, tanto as físicas quanto as mentais, e repetidas tantas vezes quanto for necessário para a confiança e o domínio. Além, disso, ele permite a oportunidade de explorar os próprios potenciais e limitações."38

Dessa forma, o brincar se torna uma atividade necessária para a formação da criança e do jovem para que estes tenham um crescimento sadio tanto físico, como mental, social e afetivo. Considerar assim a ludicidade para o universo infanto-juvenil é adotar uma postura que incentive a brincadeira como momento de educação, pois

\begin{abstract}
por meio do brincar livre, exploratório, as crianças aprendem alguma coisa sobre situações, pessoas, atitudes e respostas, materiais, propriedades, texturas, estruturas, atributos visuais, auditivos e cinestésicos. Por meio do brincar dirigido, elas têm uma outra dimensão e uma nova variedade de possibilidades estendendo-se a um relativo domínio dentro daquela área ou atividade. Por meio do brincar livre subseqüente e ampliado, as crianças provavelmente serão capazes de aumentar, enriquecer e manifestar sua aprendizagem. ${ }^{39}$
\end{abstract}

Outro fator que é possível atribuir à atividade lúdica é o trabalho psicodramático natural das brincadeiras, pois “(...) ele (o jogo) pode às vezes parecer válvula de escape, dando vazão a tendências represadas. Isso é quase sempre verdade para o jogo fictício em que a criança limita e inventa personagens. A criança procede então como escritores que põem em seu personagem o que queriam ter sido.."40 Dessa forma a atividade lúdica ganha uma dimensão terapêutica na criança e no jovem onde a elaboração de um mundo simulado se torna pressuposto para adotar papéis sociais e personificados a fim de "fugir" das pressões e infelicidades da vida. No entanto, esse mesmo escape pode significar um amadurecimento pessoal, pois a criança se vê obrigada a conflitar as atitudes de seu herói, por exemplo, com suas próprias atitudes e possibilidades.

Desse modo, "o jogo é sob certos aspectos, uma atividade de significação moral. Seguir um modelo, depois uma regra social, afirmar sua personalidade, tentar

\footnotetext{
38 Ibidem. p.22.

39 Ibidem. p.33.
} 
elevar-se a uma natureza mais alta, não são manifestações em que é difícil negar o caráter moral? Há no jogo uma moralidade encoberta."41

Explorar todos esses aspectos do jogo e da brincadeira garante à ludicidade um destaque de extrema importância no contexto da criança e do jovem. No que se refere à sua educação escolar, social e cidadã a ludicidade tem aplicações e resultados claros no desenvolvimento da sociedade contemporânea.

\section{4 - Brincando etimologicamente da pedagogia até a tecnopedagogia}

Nada mais apropriado do que brincar com a própria pedagogia nos termos de sua origem etimológica e nos conceitos que circundam o seu sentido, desmontando as peças-palavras para remontar em um novo sentido. Então, “let's play"!!!

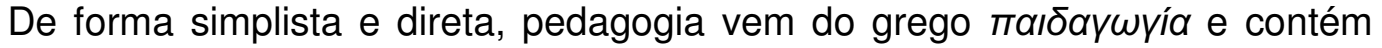
dois radicais: paidós (criança) e agogus (condução) ${ }^{42}$. É daí que vem o sentido clássico da pedagogia como o ato de educar e focar na regulação do processo de ensino e aprendizagem de crianças. Além do sentido mais educativo, a palavra carrega um sentido histórico de acompanhamento, já que na origem os pedagogos eram escravos que cuidavam e acompanhavam os filhos de cidadãos gregos até a escola.

A origem etimológica da palavra, como sempre, é de grande ajuda para compreender as reais extensões possíveis de resignificação de sentido dos vários aspectos que compreendem o homem contemporâneo. No caso da pedagogia, detecta-se algumas expansões possíveis ao seu sentido clássico exclusivamente educativo.

A condução da criança pode sair do campo meramente educacional para alcançar outros aspectos que compõem o cotidiano infantil. Ao mesmo tempo, com a tecnologia digital que converge linguagens, saberes e percepções, o próprio

\footnotetext{
${ }^{40}$ CHATEAU, J. 0 jogo e a criança. São Paulo: Summus, 1987, p. 31.

${ }^{41}$ Ibidem. p. 42.

${ }^{42}$ CUNHA, Antônio Geraldo da. Dicionário etimológico da língua portuguesa. Rio de Janeiro: Lexikon, 2007.
} 
processo educativo começa a se diluir com outras ações da criança. Na era informacional, tudo o que se consome, se produz, se comunica e se realiza acontece segundo um fluxo informativo. Nesse sentido, qualquer atitude informa e, como processo, também educa.

Em uma análise mais prática, quando uma criança brinca de "casinha", ela se vale do seu imagético de composição familiar e de vida adulta (informações que adquire automaticamente) e, de fato, aprende (se auto educa) sobre responsabilidades, relacionamentos e trocas. Do contrário, quando a criança é repreendida (processo de educação), está de fato recebendo e assimilando informações de erro, acerto e conseqüência.

Se o conceito de pedagogia for ampliado dessa forma, qualquer agente que participa da vida da criança (que a acompanha) conduz informações que demandarão que ela reaja, produzindo e enviando, para tanto, suas próprias informações. E nesse fluxo informativo existe o processo educativo. Concluindo, tudo que faz parte do contexto da criança deve ser considerado como parte do processo pedagógico.

Outra extensão etimológica possível e necessária é sobre o radical paidós (criança). Na Grécia clássica, a criança era considerada como alguém inferior ao adulto, a ser preparado para a condição de cidadão. Isso demonstra um estereótipo de um ser em busca de crescimento através de processos educativos, para fazer parte da pólis. Simplificando, a criança é aquele que se encontra na condição de busca de crescimento, de educação e conhecimento.

Em pleno século XXI com tanta informação disponível (e até por isso mesmo), nunca a célebre frase "Só sei que nada sei" de Sócrates fez tanto sentido. Com tantas áreas de conhecimento e cada uma delas com tantos dados, o indivíduo, por si só, se esvai cada vez mais do sentimento de plenitude do saber e aceita, através de uma especialização focalizada ou de uma generalização superficial, sua condição de estar sempre aprendendo. Tanto é que a educação extrapola a própria pedagogia (com foco na criança) para a andragogia, processo educacional voltado para adultos (andro é o radical grego para homem), compreendendo que, de fato, não existe um fim específico na formação humana.

Outro termo que, em plena era digital, é cada vez mais considerado, é o de heutagogia, conceito apresentado neste início de século XXI pelo psicólogo Stewart Hase, que denota a aprendizagem autodirigida, onde o indivíduo, por iniciativa 
própria, procura as fontes de informação e assimila o conteúdo para aplicá-lo como bem quiser. Sobre o conceito, o professor da ECA-USP e também presidente da Abed (Associação Brasileira de Educação a Distância) Frederic Litto afirma que "a heutagogia diz que o estudo deve ser autodirigido, que o aprendizado é feito por experiências práticas, e que, em um ambiente seguro, quanto mais o jovem erra, mais ele aprende" ${ }^{43}$. Nesse sentido, o professor defende que a educação e o processo de formação devem ser reconsiderados, pois

já passamos pela pedagogia, método que o professor determina o que e como aprender. Estamos tentando utilizar a andragogia, teoria na qual é o professor quem determina o que, mas é o aluno quem determina como. Mas hoje, já temos de ingressar na heutagogia, método pelo qual é o aprendiz quem fixa o que e como aprender. ${ }^{44}$

Um jogo de palavras a ser considerado é que paidós (criança) dá origem a outras palavras que, conectadas, resignificam o sentido da pedagogia. Uma palavra dissidente importante é paidéia que trata da criação, instrução e educação da criança, adolescente e jovem, passando pela idéia de correção e punição, ou seja, de formação. Em paralelo, outra palavra derivada é paidia, que remete diretamente às brincadeiras de criança e aos atos de jogar e brincar. De forma natural e direta, ambas as palavras conectam na criança o sentido de aprender/crescer e brincar/jogar.

Partindo do conceito ontológico de eterno devir de Heidegger ${ }^{45}$, o ser não é algo fixo e determinado, mas só é algo enquanto processo que relaciona tecnologicamente o ambiente, as coisas, a cultura e outros seres, é possível tirar a criança do foco do processo pedagógico (aprendizagem e brincadeira) e colocar generalizadamente 0 ser tecnológico - em constante devir de formação e aprendizagem segundo a sua relação cibernética com a tecnologia, também em constante mudança - como o alvo da pedagogia. É possível concluir, então, que a formação do homem é constante e não se esgota na fase da infância, adolescência ou juventude, mas se estende para a vida inteira e só acontece significativamente quando contém o elemento lúdico.

${ }^{43}$ MEGUERDICHIAN, Alan. É o estudante quem deve determinar o caminho para o conhecimento. Portal Aprendiz, 2007, http://aprendiz.uol.com.br/content/breshetere.mmp (acesso em 20 de janeiro de 2009)

44 Ibidem.

${ }^{45}$ Já tratado no capítulo 1 da dissertação. 
Começando um novo jogo de palavras e se valendo da brincadeira etimológica sobre a pedagogia até aqui desenvolvida, pegamos emprestado o termo "tecnopsicologia" elaborada por Derrick De Kerckhove ${ }^{46}$ para compreender como a tecnologia, a partir do pressuposto de ser a essência do homem, afeta o sentido do seu processo de formação, ou seja, da pedagogia. Antes, é importante compreender o que De Kerckhove define como "psicotecnologia" e, primeiro, como ele entende como o componente psicológico do homem, onde

\begin{abstract}
a nossa realidade psicológica não é uma coisa "natural". Dependende parcialmente da forma como o nosso ambiente, incluindo as próprias extensões tecnológicas, nos afeta.

Uma boa forma de compreender a psicologia, como fato da vida e como ciência, é propondo que o seu objetivo seja fornecer uma interpretação abrangente e auto-atualizável das nossas vidas, à medida que estas vão sendo influenciadas pelo meio cultural em mudança. Assim, entre as suas muitas funções reguladoras, o papel da psicologia pode ser o de interpretar e integrar os efeitos da tecnologia nos sujeitos.
\end{abstract}

Dessa forma, a tecnopsicologia, para De Kerckhove promove o estudo da "condição psicológica das pessoas que vivem sob a influência da inovação tecnológica" ${ }^{48}$. E tal condição psicológica transcende o indivíduo para uma cumplicidade social pois as tecnologias passam a amplificar e normatizar a mente do indivíduo para o coletivo. Segundo o autor,

por exemplo, enquanto a televisão é geralmente vista apenas como um difusor unilateral de materiais audiovisuais, podia ser útil para os psicólogos verem-na como uma extensão dos nossos olhos e ouvidos até os locais de produção das imagens. Quando se compreende a televisão desta forma, pouco importa se o programa é ao vivo ou gravado. De fato, telefone, rádio, televisão, computadores e outros media combinam-se para criar ambientes que, juntos, estabelecem um domínio das psicotecnologias. Vista deste prisma a televisão torna-se nossa imaginação coletiva projetada fora do nosso corpo, combinando-se numa teledemocracia consensual eletrônica. A TV é literalmente, como Bill Moyers Ihe chamou, "uma mente pública". ${ }^{49}$

Especificando o impacto das tecnologias eletrônicas-digitais sobre o ser tecnológico, o autor defende que o homem se torna capaz de reconhecer objetivamente a própria consciência pois

com a videoconferência e os videofones, a televisão aproxima-se da flexibilidade e comunicação instantânea conseguida com o telefone. De fato, estas tecnologias não apenas prolongam as propriedades de envio e recepção da consciência, como penetram e modificam a consciência dos seus utilizadores. A realidade virtual ainda está mais ajustada a nós.

${ }^{46}$ DE KERCKHOVE, Derrick. A pele da cultura. Lisboa: Ed. Relógio D’Água, 1997.

${ }^{47}$ Ibidem. p. 32.

48 Ibidem. p.32.

${ }^{49}$ Ibidem. p.33. 
Acrescenta o tato à visão e audição e está mais próxima de revestir totalmente o sistema nervoso humano do que alguma tecnologia até hoje o fez. Com a realidade virtual e a telepresença permitida pela robótica projetamos literalmente para o exterior a nossa consciência e vêmo-la "objetivamente". Esta é a primeira vez que o homem o consegue fazer. ${ }^{50}$

E nessa fuga de nós mesmos, quando parece que a subjetividade e identidade parecem se esvair perigosamente na névoa tecnológica, De Kerckhove reconhece a individualidade no contexto da comunicação digital, pois

com a televisão e os computadores mudamos a localização do processamento de informação de dentro dos nossos cérebros para telas à frente dos nossos olhos, em vez de por detrás. As tecnologias do vídeo dizem respeito não só ao nosso cérebro, mas todo o sistema nervoso e aos sentidos, criando condições para uma nova psicologia. Ainda não chegou a bom termo a nossa relação com as telas. Pode ajudar compreendermos que a TV não está em competição com os livros, sugerindo antes algo completamente diferente. Propõe uma imaginação coletiva como algo que podemos realmente consumir, embora ainda não participemos diretamente nela. Com efeito, a característica essencial, a interação, a capacidade que garante a nossa autonomia individual dentro da poderosa tendência da coletivização psicotecnológica, é fornecida pelos computadores e ainda mais eficazmente pelas redes de computadores. ${ }^{51}$

Para concluir o jogo de palavras iniciado por Derrick De Kerckhove, e aderindo à pesquisa proposta nesta dissertação, propõe-se aqui o termo "tecnopedagogia", no sentido de considerar que o ser tecnológico se forma através da tecnologia e que esta é inerente ao contexto do ser. Ou seja, as tecnologias, ou melhor, as tecnopedagogias ampliam o processo de formação do homem que é essencialmente tecnológico.

É exatamente no conceito de tecnopedagogia, um processo que compreende a pedagogia em confluência com a ludicidade na formação do ser tecnológico, que se procura compreender o mundo dos jogos eletrônicos.

Não posso deixar de citar os dois encontros presenciais e, de certa forma, muito próximos que tive com o professor Derrick De Kerckhove ${ }^{52}$, quando tive a honra de ter um momento de conversa (pequena co-orientação, academicamente falando). De Kerckhove, além de discípulo direto de Marshall McLuhan, é renomado

\footnotetext{
${ }^{50}$ Ibidem. p.34.

${ }^{51}$ Ibidem. p.35.

${ }^{52}$ Propiciados pela rede de contatos e convênios internacionais firmados entre o Atopos (grupo de estudos sobre o impacto das tecnologias digitais de comunicação, coordenado pelo professor Massimo Di Felice - orientador dessa dissertação) e vários pesquisadores renomados dos mais diversos centros de pesquisa e universidades.
} 
pela importância de seus estudos e pesquisas sobre o digital. E posso afirmar que grande parte da minha empolgação em desenvolver essa pesquisa é motivada pela influência acadêmica de De Kerckhove e de seu carisma pessoal.

Da mesma forma, fica registrado a minha enorme gratidão pelo grupo do Atopos que, como exemplo único de estrutura democraticamente bem sucedida como idealizada por Massimo Di Felice, é composto de pesquisadores de alto nível e amigos que incentivam e ajudam no que precisamos. Os bons momentos (recheados de teor lúdico) promovem crescimento e são importantíssimos para o nosso processo de formação como pesquisadores.

Agora sobre os encontros.

No primeiro, tivemos a oportunidade de visitar o Jardim Botânico e passar a tarde juntos falando de coisas casuais como pontos turísticos, dança de salão, natureza... No caminho de volta ao hotel, tive a honra de conversar sobre os objetivos preliminares da minha pesquisa e como achava o seu conceito de tecnopsicologia importante para embasar as considerações teóricas da dissertação. Tive um caloroso incentivo e várias idéias foram colocadas como provocação de temáticas a serem abordadas.

No segundo encontro, em plena noite, em um bar, pude consultá-lo sobre "pegar emprestado" o seu conceito de tecno-psicologia para aplicá-lo na dissertação como "tecno-pedagogia". Ele não só permitiu como deu o maior apoio afirmando que quando um pesquisador propõe uma idéia que serve de base para outras novas idéias existe uma recompensa acadêmica que não pode ser mensurada. Assim, com tanto incentivo, posso afirmar que se esta dissertação pode ser resumida em um conceito, tem a honra de receber o título de "tecno-pedagogia".

\section{5 - Tecno-pedagogias: o lúdico e o pedagógico no contexto tecnológico digital}

A tecnologia do digital promove a interatividade mediada tecnologicamente entre os homens e, também, a interação entre homens e máquinas. Essa interação, como troca informativa, caracteriza um processo pedagógico e, portanto, lúdico, como já visto. Para as possibilidades educativas, as tecnologias digitais começam a ganhar reconhecimento e acervo intensivamente. É possível destacar um esforço de 
entidades e indivíduos em incentivar o desenvolvimento de plataformas digitais, principalmente, que auxiliem ativamente no processo educativo. Os primeiros esforços mostram a eficiência dos jogos eletrônicos para o público infanto-juvenil, pois "colocar material infantil em multimídia, sob a forma de CD-ROM (isto é, de átomos), funciona particularmente bem porque uma criança quer ver ou ouvir a mesma história várias vezes." 53

Além da narrativa repetida, a plataforma multimídia interativa possibilita que a criança desenvolva a ponte entre a lógica e a sensibilidade, pois

existe uma polaridade (por mais artificial que seja) entre a tecnologia e as humanidades, a ciência e a arte, os lados direito e esquerdo do cérebro. É provável que o campo ainda germinante da multimídia venha a se tornar uma daquelas disciplinas que, como a arquitetura, estabelecem uma ponte entre ambos os pólos. ${ }^{54}$

Os recursos multimídia, portanto, tornam possível a exploração das informações e conhecimentos adquiridos (ciência) ao mesmo tempo em que abrem espaço para divulgar as novas manifestações culturais (arte). Segundo Negroponte, o computador deixou de oferecer exclusivamente um ambiente lógico para o uso científico e se constitui também em contexto cultural como possibilitadora de novas linguagens de tal forma que

os computadores pessoais afastaram a ciência da computação do mero imperativo tecnológico e desenvolvem-se agora mais à maneira da fotografia. A computação não é mais domínio exclusivo dos militares, do governo e dos negócios, mas está sendo canalizada diretamente para as mãos de indivíduos bastante criativos em todos os níveis da sociedade, tornando-se um meio de expressão artística tanto no seu emprego quanto no seu desenvolvimento. Os meios e mensagens da multimídia irão se tornar uma mescla de conquistas técnicas e artísticas. E os produtos para o consumidor serão a força motriz.

O ramo dos jogos eletrônicos (15 bilhões de dólares no mundo todo) é um exemplo. Esses jogos representam um negócio maior do que a indústria cinematográfica americana e que está crescendo muito mais rápido que ela. $^{55}$

De fato os computadores pessoais são responsáveis por mudanças significativas no cotidiano e na estrutura social. Os jogos eletrônicos são ícones da tecnologia digital aliada à interatividade como novo paradigma social, pois seu crescimento intenso mostra que grande parcela vem consumindo esse mediador lúdico.

\footnotetext{
${ }^{53}$ NEGROPONTE, Nicholas. A vida digital. São Paulo: Cia das Letras, 1995. p. 67.

${ }^{54}$ Ibidem. p. 81.

${ }^{55}$ Ibidem. p. 82-83.
} 
A tecnologia digital possibilita não só a participação do usuário (como acontece nos games eletrônicos), mas também permite a criação, por meio das linguagens audiovisuais, por parte de qualquer pessoa que tenha acesso aos recursos digitais (cada vez mais baratos e acessíveis).

O computador está mais presente nas escolas privadas e públicas. É fato que muitos laboratórios de informática são subutilizados ou mesmo inutilizados por falta de preparo dos educadores (fato que ocorre principalmente nas escolas públicas brasileiras). Com a falta de investimento e a desatualização frenética por conta do desenvolvimento relâmpago das novas tecnologias, as escolas não têm possibilidade de acompanhar as novas produções informacionais.

No entanto, as possibilidades computacionais criaram um novo paradigma pedagógico. Os educandos tem a possibilidade de ter uma participação diferente em sala de aula, pois

de repente, o aprender fazendo tornou-se regra, e não exceção. Uma vez que um computador pode hoje simular quase tudo, não se precisa mais dissecar um sapo para aprender sobre ele. Em vez disso, pode-se pedir às crianças que projetem sapos, que construam um animal com um comportamento semelhante ao do sapo, que modifiquem esse comportamento, que simulem os músculos e que brinquem com o sapo. ${ }^{56}$

Apesar da imensa exclusão digital existente em todo o mundo, o fato é que as novas tecnologias e a Internet são base para uma sociedade mais ativa e produtora de informação e conhecimento. A Internet só não é mais uma mídia de massa tradicional (um único produtor e vários receptores) porque a produção de conteúdo está em cada página criada, seja de um blog, seja de um site de relacionamento (Orkut, por exemplo) seja uma página de apresentação de trabalho.

Já que as crianças produzirão e se comunicarão através dessa linguagem digital, é de se esperar que os aspectos lúdicos e educacionais sejam mais atrativos e eficientes se adotarem essa mesma linguagem. Os jogos eletrônicos podem potencializar a junção entre ludicidade e educação no contexto da tecnologia digital e da Internet. De acordo com Vitória (apud Viana),

o brinquedo digital é o brinquedo encarado como possibilidade de constituição de identidades de sujeitos eficientes, eficazes, produtivos, versáteis e adaptados ao novo perfil tecno-industrial necessário para a vida em uma "sociedade da informação". Algo como do homo ludens ao homo

${ }^{56}$ Ibidem. p. 190. 
"ciber-produto", o que novamente evoca a idéia de um brinquedo associado ao sujeito que se pretende (in)formar. ${ }^{57}$

Dessa forma o brinquedo digital, por suas possibilidades interativas e multimidiáticas, se torna suporte para formar uma criança ativa no meio cibercultural. Essa criança que atua brincando e aprendendo no ciberespaço acompanhará todas as novas possibilidades que surgirão no desenvolver das tecnologias em rede, pois desde cedo está sendo alfabetizada digitalmente, além de se desenvolver nos campos científicos e artísticos, pois

\begin{abstract}
quando uma criança utilizar uma linguagem de computador como Logo para fazer um desenho no seu monitor, essa imagem é uma expressão artística e matemática ao mesmo tempo, podendo ser vista por qualquer um desses prismas. Até mesmo algo abstrato como a matemática pode valer-se de elementos concretos das artes visuais. ${ }^{58}$
\end{abstract}

Tal alfabetização dará às crianças ferramentas para poder se expressar e até condições de se inserir no mercado com mais facilidade, já que conhecimentos de informática se tornam necessários cada vez mais em todos os segmentos da sociedade. Além disso, estará incluída em uma sociedade que constrói coletivamente o conhecimento e a inteligência.

\title{
2.6 - A mudança de valores da sociedade em rede com a ética dos hackers
}

A grande missão da educação, ao propiciar a formação de indivíduos capacitados ao trabalho e à vida social, pode ser entendida na sua função primordial de ambiente de construção de valores éticos, na construção de uma sociedade sustentável. A ética (todos os valores comuns a uma sociedade), então, define os fundamentos do processo de educação e formação de uma comunidade. Ao mesmo tempo, a ética é formulada segundo o estabelecimento de potenciais e limites produtivos, culturais, sociais e políticos condicionados ao conjunto tecnológico dessa mesma sociedade, ou seja, a construção de valores depende de seu contexto tecnológico já que, como colocado por Galimbert no primeiro capítulo, “(...) não é

${ }^{57}$ VIANA, Claudemir. $O$ lúdico e a aprendizagem na cibercultura: jogos digitais e Internet no cotidiano infantil. 2005. p. 275. Tese de Doutorado - Escola de Comunicações e Artes da USP, São Paulo. p. 57.

${ }^{58}$ NEGROPONTE, Nicholas. A vida digital. São Paulo: Cia das Letras, 1995. p. 209. 
mais a ética que promove a técnica, mas é a técnica que condiciona a ética, obrigando-a a tomar posição a partir de uma realidade, não mais natural, mas artificial, que a técnica não cessa de construir e tornar possível, qualquer que seja a posição assumida pela ética." 59

Parece, então, existir uma relação intrínseca estabelecida entre tecnologia, ética e educação, sendo necessário compreender a intersecção ética promovida mediante as tecnologias digitais e, assim, compreender as novas abordagens educativas lúdicas. Sobre esse tema, a obra literária de Pekka Himanen, "A ética dos hackers e o espírito da era da informação", iconiza a compreensão sobre os novos valores éticos que estão em processo de construção e absorção na sociedade contemporânea. O autor, doutor em filosofia pela Universidade de Helsinque (Finlândia), conta com a colaboração do sociólogo Manuel Castells e do hacker Linus Torvalds (criador do sistema Linux) para compreender os novos paradigmas éticos da sociedade em rede. A obra é um contra-ponto ao discurso desenvolvido por Max Weber em 1905, "A ética protestante e o espírito do capitalismo", onde a cultura emergente pela produção industrial e comercial sob influência ideológica do protestantismo formulam as bases do capitalismo. O contra-discurso de Hinamen defende a idéia de que a cultura hacker, emergente pelas tecnologias digitais de comunicação e produção definem novos valores éticos que compõem o indivíduo da era da informação.

Primeiramente, Hinamen apresenta o conceito de "hacker" segundo a autodefinição encontrada no arquivo de jargões dos próprios hackers que se descrevem como

\begin{abstract}
"indivíduos que se dedicam com entusiasmo à programação" que acreditam que "o compartilhamento de informações é um bem poderoso e positivo, e que é dever ético dos hackers compartilhar suas experiências elaborando softwares gratuitos e facilitar o acesso a informações e a recursos de computação sempre que possível"60
\end{abstract}

Essa auto-definição já demonstra os vários aspectos que motivam e que, portanto, formulam os novos valores éticos dos hackers e que devem ser considerados na conjunção tecnologia e educação. O primeiro ponto a se notar é em relação à fissuração que os hackers têm pela programação de computadores. É uma

${ }^{59}$ GALIMBERTI, Umberto. Psiche e techne: o homem na idade da técnica.São Paulo: Paulus, 2006, p. 519. 
atividade que promove prazer, principalmente, na aquisição de conhecimento onde “(...) os hackers programam porque os desafios da programação são interessantes. Os problemas encontrados na programação causam curiosidade nos hackers e os tornam ávidos por mais conhecimento." ${ }^{61}$ São, então, movidos por uma paixão em uma atividade que é "intrinsicamente interessante, inspiradora e lúdica." "62

Se afasta da ética protestante do trabalho que, hoje, é ainda predominante e que considera que "o trabalho deve ser visto como um objetivo em si; deve ser feito da melhor maneira possível; e deve ser encarado como um dever, que deve ser feito simplesmente porque deve ser feito."63 Apesar de estar nos seus primórdios de difusão, a ética hacker do prazer e paixão pela informação, conhecimento e interação no trabalho começa a ser difundida nas organizações que, cada vez mais esperam colaboradores do que empregados como público interno. Dessa forma, a compreensão da ética hacker sobre o contexto profissional é que

o trabalho é uma parte da vida, na qual também deve existir espaço para outras paixões. Reformular o modo de trabalho não é apenas uma forma de respeitar os trabalhadores, mas os seres humanos como tais. Os hackers não são adeptos do provérbio "tempo é dinheiro", mas a outro ditado, "tempo é minha vida". E, de certo, essa é a nossa vida, que deve ser vivida integralmente, e não como um protótipo da versão definitiva cheio de erros. $^{64}$

Dessa forma, o dinheiro faz parte da vida mas não é o fim nem o meio para todas as aquisições de valor. Segundo a ética hacker,

(...) obter reconhecimento numa comunidade que compartilha suas paixões é mais importante e proporciona mais satisfação que o dinheiro, da mesma forma que estudiosos na academia. A diferença fundamental da ética do Protestantismo é que, para os hackers, o reconhecimento individual não deve substituir a paixão - pelo contrário, o reconhecimento deve resultar da paixão, da criação de algo socialmente válido para essa comunidade criativa. ${ }^{65}$

Sendo assim, "o fator organizacional fundamental não é nem o trabalho nem o dinheiro, mas a paixão e o desejo de criar, juntos, algo que seja valioso em termos sociais." ${ }^{66} \mathrm{E}$ para isso, "os hackers otimizam o tempo para ter mais espaço para

${ }^{60}$ GALIMBERTI, Umberto. Psiche e techne: o homem na idade da técnica.São Paulo: Paulus, 2006, p. 7.

${ }^{1}$ HIMANEN, Pekka. A ética dos hackers e o espírito da era da informação: a importância dos exploradores da era digital. Rio de Janeiro, Campus, 2001, p. 19.

62 lbidem, p. 21.

${ }^{63}$ Ibidem, p. 23.

${ }^{64}$ Ibidem, p. 47.

${ }^{65}$ Ibidem, p. 57.

${ }^{66}$ Ibidem, p.58. 
brincar"67 e promovem a noção de que "o uso de máquinas para otimizar e flexibilizar o tempo deveria proporcionar aos seres humanos um padrão de vida cada vez menos automático - menos otimizado e rotineiro." 68

Além da questão do prazer e do lúdico como valores essenciais da ética hacker, a grande inovação dessa cultura emergente está no modelo aberto de produção de bens, no caso, principalmente de softwares onde "o hacker dá sua criação livremente para terceiros para que possam usá-la, testá-la e desenvolvêla." ${ }^{69}$ Dessa forma, Himanen conclui que

as atividades dos hackers têm como máximas a paixão e a liberdade de agir; entretanto, a essas máximas pode-se acrescentar um aspecto mais prático de que, na Era da Informação, as novas informações são criadas mais efetivamente se introduzidos o elemento lúdico e a possibilidade de trabalhar segundo o ritmo individual de cada um. Pode-se igualmente dizer que o modelo aberto não só se justifica do ponto de vista ético, mas também é muito poderoso na prática. ${ }^{70}$

E essa eficiência prática de produção através da abertura e compartilhamento e não da competitividade faz um paralelo à base da produção de conhecimento acadêmico e científico, pois a

\begin{abstract}
a ética cientifica gera um modelo no qual as teorias são desenvolvidas coletivamente e seus defeitos são percebidos e gradualmente eliminados por meio de criticas de toda a comunidade científica.

É claro que os cientistas também elegeram esse modelo por motivos éticos, mas também porque ele demonstrou que é a forma mais bem-sucedida de criar conhecimentos científicos. Toda a compreensão que temos da natureza baseia-se nesse modelo acadêmico ou científico. $O$ motivo pelo qual o modelo original de fonte aberta dos hackers funciona tão efetivamente parece dever-se ao fato de que, além de os hackers o utilizarem para concretizar suas paixões e estarem motivados pelo mero reconhecimento, tal modelo se ajusta ao modelo aberto acadêmico ideal, que, historicamente, é o mais bem adaptado para a criação de informações. $^{71}$
\end{abstract}

De fato, o modelo aberto incentiva a criatividade e a auto-correção através da iniciativa e crítica coletivas no processo coletivo de desenvolvimento. Ao mesmo tempo que extremamente eficiente, o modelo aberto promove não só o desenvolvimento coletivo de conhecimento, mas também a aprendizagem coletiva pela participação. Para Himanen,

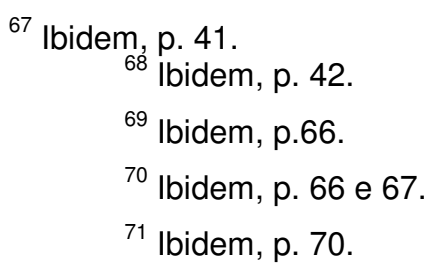


o processo típico de aprendizagem dos hackers começa quando um problema interessante é estabelecido. O hacker, então, se lança em busca da possível solução utilizando, para tanto, diversas fontes e, depois, submete seu resultado a exaustivos testes. Aprender cada vez mais sobre determinado assunto torna-se uma obsessão para o hacker. A princípio, Linus Torvalds, um auto-didata, aprendeu a programar computadores num computador herdado de seu avô. Ele criava problemas para si mesmo e descobria do que ele precisava para resolvê-los. Muitos hackers aprenderam a programar dessa maneira informal, perseguindo suas próprias paixões. A capacidade que muitas crianças possuem de aprender problemas intrincados de programação demonstra a importância da paixão no processo de aprendizagem, em contraposição ao ritmo lento a que seus contemporâneos são submetidos em escolas tradicionais. ${ }^{72}$

Além do empreendedorismo computacional individual, os hackers trocam informações e aprendem coletivamente através da interatividade no processo de desenvolvimento de soluções coletivas. Assim,

\begin{abstract}
um aspecto bem característico do modelo de aprendizagem dos hackers reside no fato de que o conhecimento de um hacker ensina a outro. Quando um hacker estuda o código-fonte de um programa, não é raro esse hacker desenvolver ainda mais esse código e, dessa forma, outras pessoas podem aprender com seu trabalho. Quando um hacker verifica fontes de informação na Rede, ele muitas vezes agrega informações úteis a partir de suas próprias experiências. Forma-se uma discussão contínua, crítica e crescente em relação a diversos problemas. O mérito de participar dessas discussões é simplesmente adquirir reconhecimento. ${ }^{73}$
\end{abstract}

A troca de conhecimento não exige, necessariamente, um aprofundamento intenso no conhecimento das linguagens computacionais. Qualquer hacker, em qualquer nível de experiência e conhecimento, pode participar das trocas informativas e, portanto, entrar no círculo virtuoso do aprendizado e produção nas comunidades hackers eliminando, a exemplo do fim da dicotomia emissor-receptor na estrutura da comunicação digital, o limiar entre professor e aluno. Assim,

o modelo aberto de aprendizagem dos hackers pode ser denominado de "Academia da Rede". Esse ambiente de aprendizagem, que está em um processo contínuo de evolução, foi criado pelos próprios aprendizes e possui muitas vantagens. No mundo dos hackers, os professores - ou aqueles indivíduos que montam as fontes de informação - são muitas vezes aqueles indivíduos que acabaram de aprender algo. Isso é vantajoso pois, muitas vezes, alguém que acabou de estudar determinado assunto está mais apto a ensiná-lo do que um perito, para quem o assunto em estudo já não é tão novo assim e que de certo já não tem mais aquele feeling de como os novatos pensam. Para um perito, colocar-se no lugar de um aprendiz freqüentemente requer níveis de simplificação a que ele resiste por motivos intelectuais. Além disso, em muitos casos, pode ocorrer de um perito não achar necessariamente atraente a idéia de ensinar matérias básicas, ao passo que um aluno talvez ache a experiência bastante

\footnotetext{
${ }^{72}$ Ibidem, p. 74.

${ }^{73}$ Ibidem, p. 75.
} 
compensadora, já que ele não terá a obrigação de assumir a posição de instrutor e, geralmente, não tem muitas oportunidades de utilizar seus talentos. Devido à sua própria natureza, o processo de ensino também requer uma análise abrangente do assunto. Se o indivíduo está realmente apto a ensinar, então a matéria deve ser bastante clara para ele. Enquanto prepara o material, é preciso atentar para possíveis perguntas e oposições. $^{74}$

Ao juntar o prazer e paixão como valores essenciais para a produção e a interatividade do modelo aberto de aprendizagem, a ética hacker compõe parte essencial dessa dissertação já que converge na comunicação digital o lúdico e o processo de formação do ser digital. Como já foi citado, a ética hacker é minoritária, mas é interessante notar o quanto desses valores já estão impregnados nas gerações "nativas" da rede (as gerações que falam: "Não sei como era possível viver sem internet...").

Outra questão da ética hacker extremamente alinhada com os objetivos dessa dissertação reside no fato de que os hackers são usuários nativos dos games. $E$ além de usuários, são, também, os principais desenvolvedores de games, pois são os únicos capazes de, através do lazer e da criatividade inerentes à sua cultura, organizar a lógica computacional na construção de plataformas de jogos, ou seja, se divertir com códigos binários arranjados.

Os games são, então, uma tradução e uma conseqüência natural da ética hacker, ao mesmo tempo em que esta surge naturalmente no sucesso de consumo dos games. Quando qualquer usuário de game procura na internet uma solução para um problema enfrentado no jogo (e muitas das soluções estão na alteração de alguns códigos via programas hackers ou via programação direta) eles já estão incorporando parte do espírito hacker. E quando decidem compartilhar alguma informação para ajudar outros jogadores, estão promovendo o conhecimento coletivo pelo modelo aberto de aprendizagem.

Se a interação entre a tecnologia e homem promove a sua formação tendo como motivação e conseqüência a ludicidade, como propôs este capítulo, faz-se necessário compreender de forma mais profunda o universo peculiar do produto/contexto mais evidente da conjunção entre tecnologia e elemento lúdico, os games, tentando analisar os pontos tecno-pedagógicos possíveis. Os próximos capítulos propõem o aprofundamento analítico sobre o mundo dos games.

\footnotetext{
${ }^{74}$ Ibidem, p. 75.
} 


\section{CAPÍTULO 3 - Os games (jogos eletrônicos) como tecno-pedagogia}

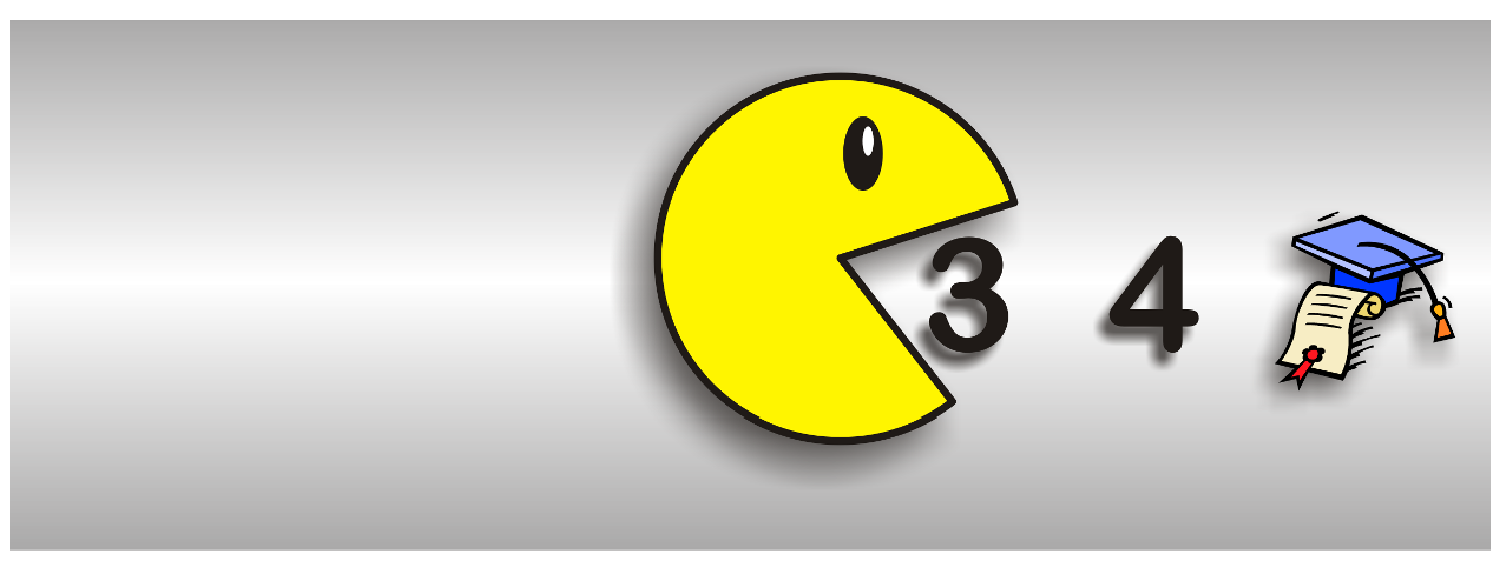




\section{CAPÍTULO 3 - Os games (jogos eletrônicos) como tecno-pedagogia}

\section{Introdução ao capítulo}

A minha infância se mistura muito com a ludicidade eletrônica/digital. Lembrome bem de um tabuleiro de xadrez eletrônico que, por comando de toques e luzes que piscavam em todas as casas, assimilava as minhas jogadas e comandava as suas. Nunca fui bom em xadrez e sempre perdi daquela máquina, mesmo no nível mais fácil, onde o computador interno estava limitado a poucos cálculos probabilísticos. Mas me fascinava a idéia de que existia uma inteligência eletrônica com quem interagir e que me ensinava como jogar xadrez.

Também tenho lembranças dos primeiros computadores que tivemos. Aquela tela verde de fósforo onde experimentei jogar os primeiros quebra-cabeças digitais em imagens extremamente rudimentares. Lembro dos primeiros jogos construídos com 16 cores e, com nostalgia, me lembro de jogos que tinha que copiar em mais de 15 disquetes de $3 \frac{1}{2} 2^{\prime \prime}$.

Hoje eu me assusto, pois chegamos a interagir com a máquina através dos nossos movimentos corporais e até por ondas cerebrais. Hoje, temos videogames mais caros e potentes do que computadores de escritórios. Hoje, o sonho de consumo de celulares arrojados se equipara ao desejo de ter um carro top. Hoje, existem mais tipos de games do que gêneros de cinema...

Me lembro do passado com nostalgia, estou no presente admirado e assustado e mal consigo esperar pelo futuro.

O universo dos games, como proposto nessa pesquisa, deve ser considerado como o contexto lúdico que, através das interfaces digitais de interação, faz parte da formação do ser digital. A compreensão desse universo se faz necessária para traçar as confluências entre o homem e a tecnologia.

Para compreender o universo dos videogames, esta dissertação toma como partido a sua história, sua importância econômica (consumo e comportamento), suas tipologias e suas abordagens educativas. 


\section{1 - História analítica dos videogames}

A história dos videogames pode ser analisada pelas inovações tecnológicas que influenciaram diretamente na relação entre homem e tecnologia. Ao invés de fazer um relato descritivo e linear da história, optou-se por uma análise crítica de aspectos tecnológicos que aprofundam essa relação e fortalecem o conceito de tecno-pedagogia adotada nessa pesquisa.

Nem todas as plataformas, consoles e tecnologias são abordados. A história analítica dos games destaca as principais inovações e os paradigmas que surgem ao longo das gerações dos games. Seja pelo sucesso de vendas, seja pelos saltos tecnológicos e de interatividade, os produtos lúdico-eletrônicos promoveram a crescente fusão do homem e da tecnologia.

Para realização dessa análise, as informações históricas são extraídas de sites que, pelo caráter interativo e dinâmico em que foram (e continuam sendo) construídos, estão sempre atualizados. Dessa forma, são ideais para reportar uma história que não pára de evoluir e cada vez mais, de forma mais intensa. Os aspectos históricos aqui apresentados estão registrados e compilados nas plataformas do Wikipedia (http://pt.wikipedia.org/wiki/História_dos_videogames) e no Retrospace (http://outerspace.ig.com.br/retrospace/) e a análise da história adotada destaca a interatividade entre o homem e a tecnologia.

\subsection{1 - Primeira geração dos games: os primórdios}

Assim como toda invenção (que sempre se baseia em conhecimentos e tecnologias anteriores) não tem um marco inicial muito definido, os games também têm um começo diluído. Isso porque, atrelado a programas de interesse militar, os primórdios dos jogos eletrônicos não passavam de experiências e exibições para promover publicitariamente a importância e interesse dos computadores. No entanto, mesmo subordinadas aos departamentos de pesquisa e desenvolvimento tecnológico, as primeiras plataformas lúdicas computacionais inauguraram o pressuposto interativo entre o homem e o digital.

Ainda assim, pode-se considerar como o primeiro game o "Tennis Programming" (que mais tarde passou a ser conhecido por "Tennis for Two"), criado em 1958 por William Higinbotham (que teve participação ativa na criação da primeira bomba atômica) no laboratório americano de pesquisas militares Brookhaven 
National Laboratory. O jogo consistia na interação entre dois usuários que controlavam através de um botão giratório e de um botão de ação a posição e o momento da rebatida, respectivamente, de um ponto (bola) que se movia horizontalmente na tela de um osciloscópio (computador analógico). Apesar da simplicidade e do gráfico rudimentar, o jogo promoveu a interação lúdica mediada por computador e serviu estrategicamente de aproximação e euforia em relação à tecnologia em plena Guerra Fria.

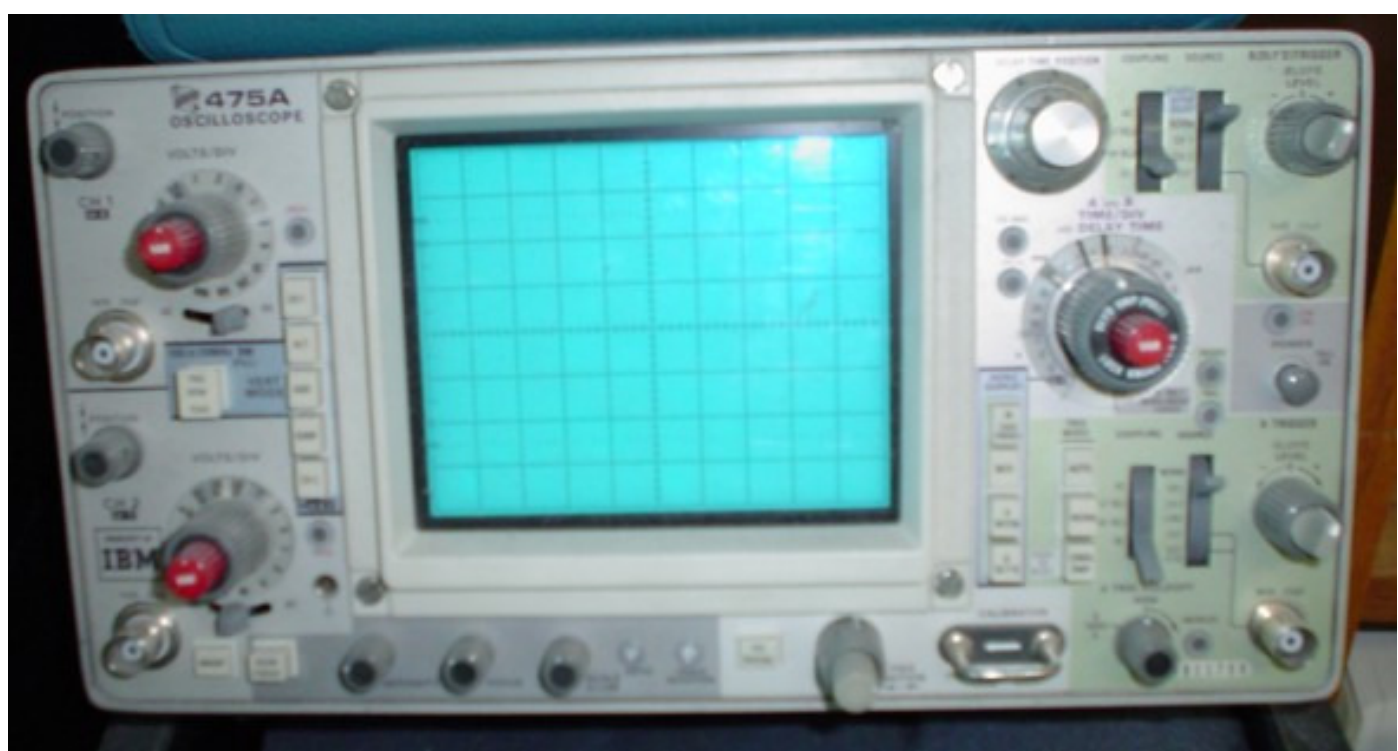

llustração 1 - Exemplo de um osciloscópio (computador analógico do final da década de 50) Fonte: http://pt.wikipedia.org/wiki/Ficheiro:Oscilloscope.jpg (Acesso em: 23 dez.2008)
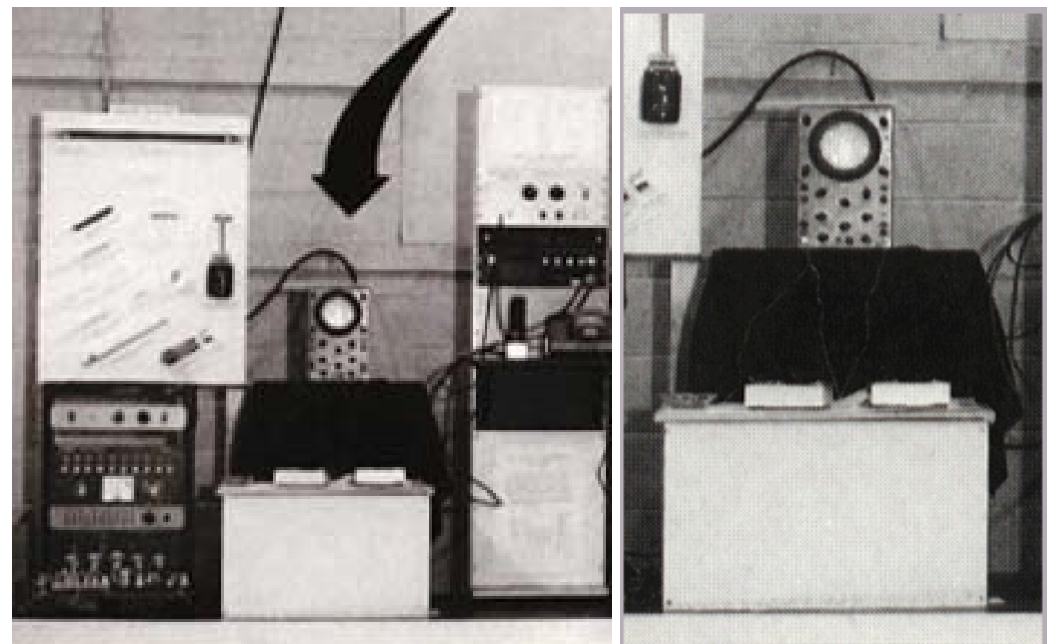

Ilustração 2 - Osciloscópio utilizado para os testes de William Higinbotham

Fonte: http://www.retrofollie.com.2008/07/tennis-for-two.html (Acesso em: 23 dez.2008) 


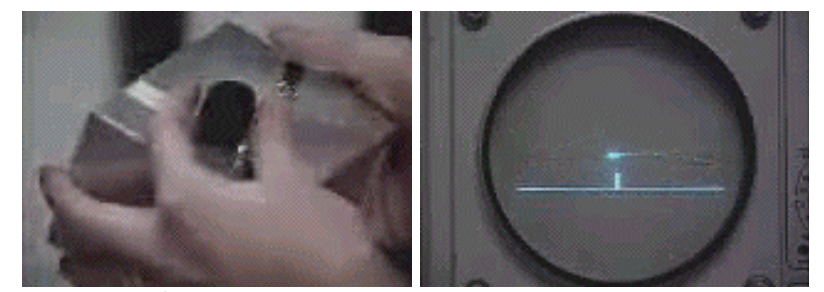

llustração 3 - Controle rudimentar e tela do jogo "Tennis for two"

Fonte: http://outerspace.ig.com.br/retrospace/ (Acesso: em 23 dez.2008)

Depois dessa experiência, em 1962 um grupo de estudantes do Massachusetts Institute of Technology (MIT) desenvolvia e testava o Spacewar!, um game que exigia o processamento de um imenso computador (maior do que uma mesa comum) e que custava, na época, cerca de 120 mil dólares. Steve "Slug" Russell, com o auxílio de seus colegas Dan Edwards, Alan Kotok, Peter Sampson e Martin Graetz, se desafiaram a transportar a ficção espacial da literatura do início do século 20 para outra mídia, no caso, para o computador DEC PDP-1 recém adquirido pela universidade (que substituía as válvulas por transistores).

O Spacewar! foi desenvolvido seguindo os conceitos da Física sobre gravidade e inércia espacial onde os jogadores, através de comandos enviados por um console simples, controlavam as naves e seus tiros e, com astúcia, poderiam aproveitar as atrações de corpos celestes para fugir e atacar. É notável que o jogo, usando a potência de apenas 18 bits de processador e 4KB de memória do DEC PDP-1, tenha gerado grande interesse tecnológico tanto dos visitantes quanto dos pesquisadores do MIT.
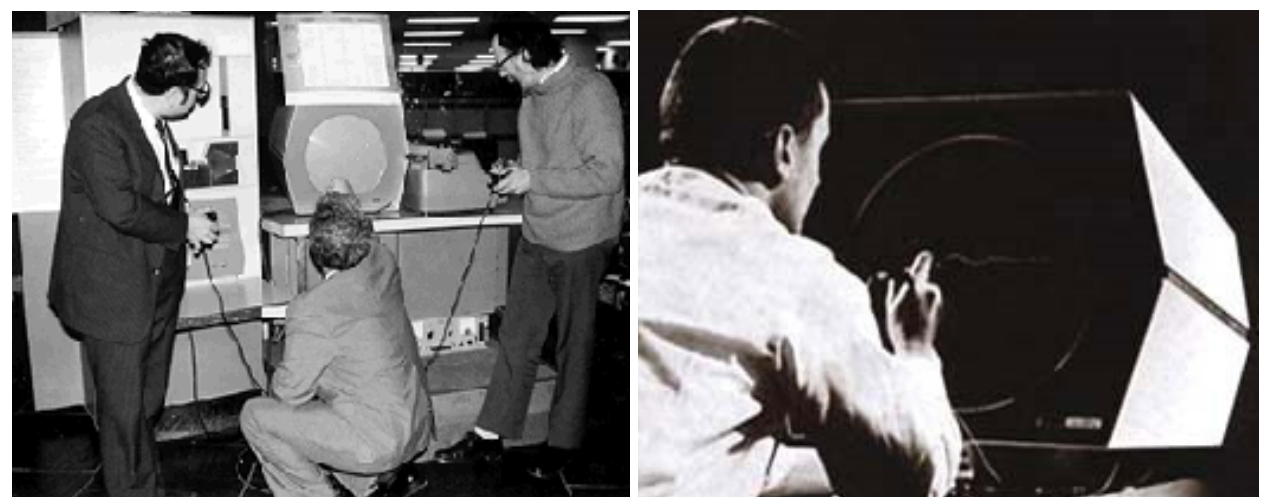

llustração 4 - O computador DECPDP-1 onde se desenvolveu o Spacewar!, em 1962 Fonte: http://outerspace.ig.com.br/retrospace/ (Acesso em: 23 dez.2008) 


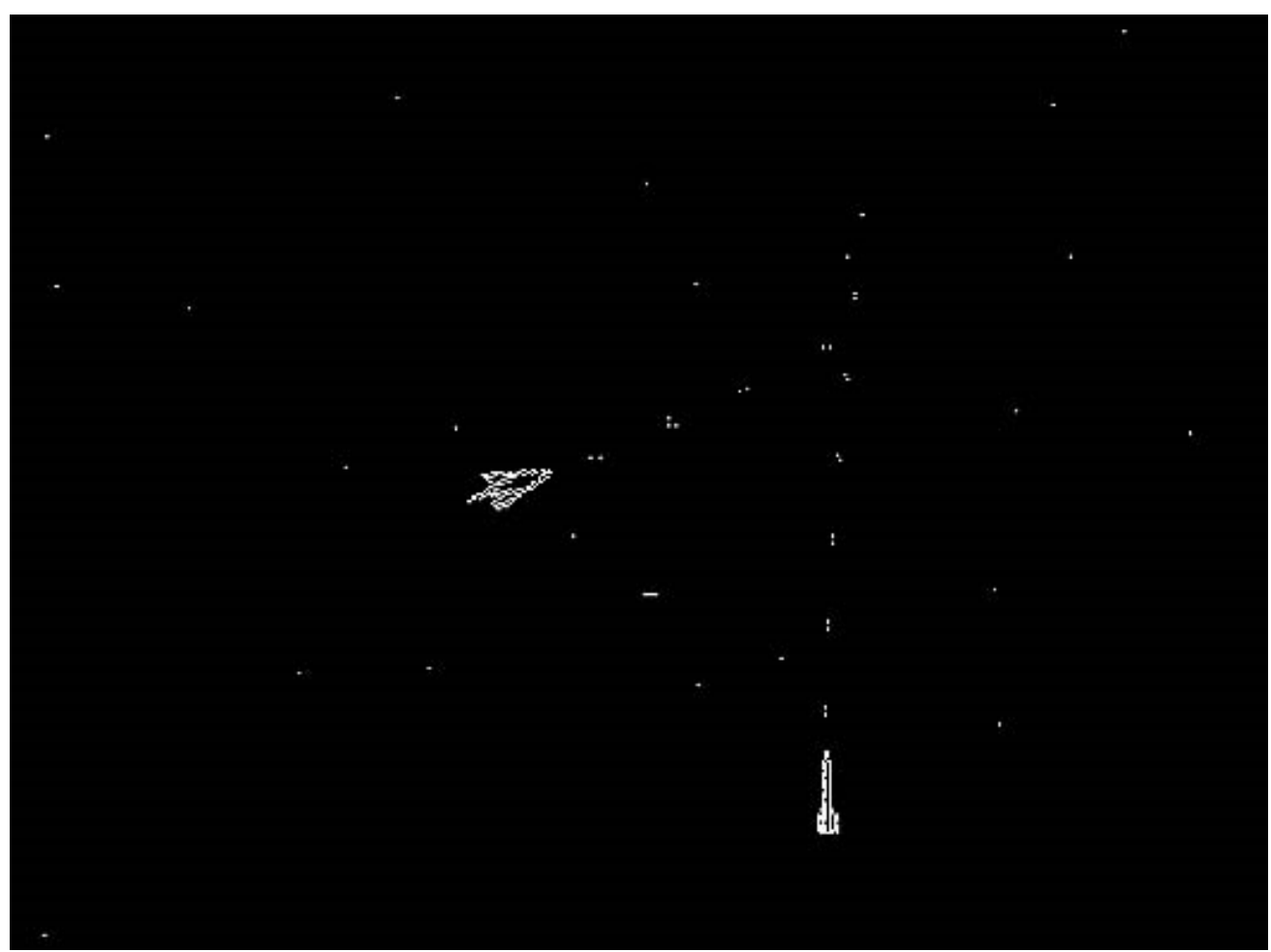

Ilustração 5 - Tela do jogo Spacewar!, de 1962

Fonte: http://outerspace.ig.com.br/retrospace/ (Acesso em: 23 dez.2008)

Saindo do contexto dos laboratórios e centros de pesquisa e caminhando para o mundo empresarial, os jogos eletrônicos começavam a ser de fato considerados como bens de alto consumo já que a Magnavox, subsidiária da Philips, lançou em 1972 o Odyssey 100, o primeiro videogame doméstico, projetado com bases nos protótipos do engenheiro alemão Ralph Baer (que patenteou o primeiro console e foi considerado o pai dos videogames).

O Odyssey 100 se conectava aos aparelhos televisivos domésticos e contava com jumpers (placas de circuito externa) que, dependendo da combinação de encaixe, ofereciam diferentes jogos - a maioria de esportes. Além dos dois controles, era possível adquirir um rifle opcional para interagir com elementos da tela. Apesar de tal complexidade de interface, o console precisava de cartões plásticos impressos colocados em frente à tela da televisão para amenizar o seu fraco processador gráfico (simulando a grama da quadra de tênis, por exemplo). Assim, O Odyssey 100, em seu lançamento, teve 100 mil consoles e 20 mil rifles vendidos, revelando que o público ainda esperava um maior refinamento tecnológico dos videogames domésticos. 


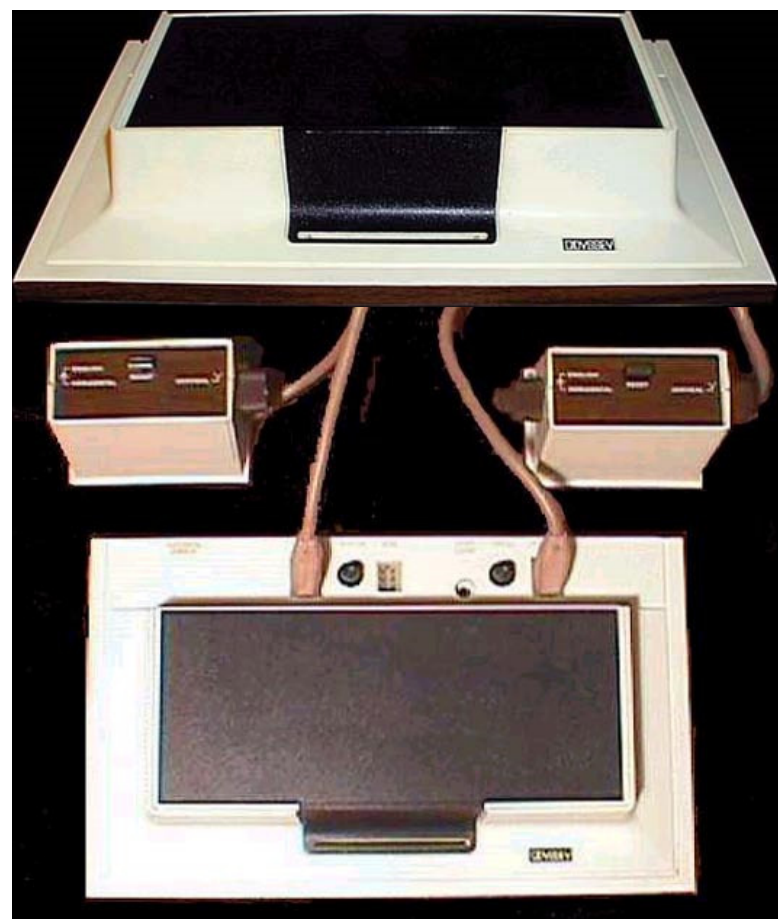

llustração 6 - Odyssey 100, primeiro console doméstico, de 1972

Fonte: http://outerspace.ig.com.br/retrospace/ (Acesso em: 23 dez.2008)

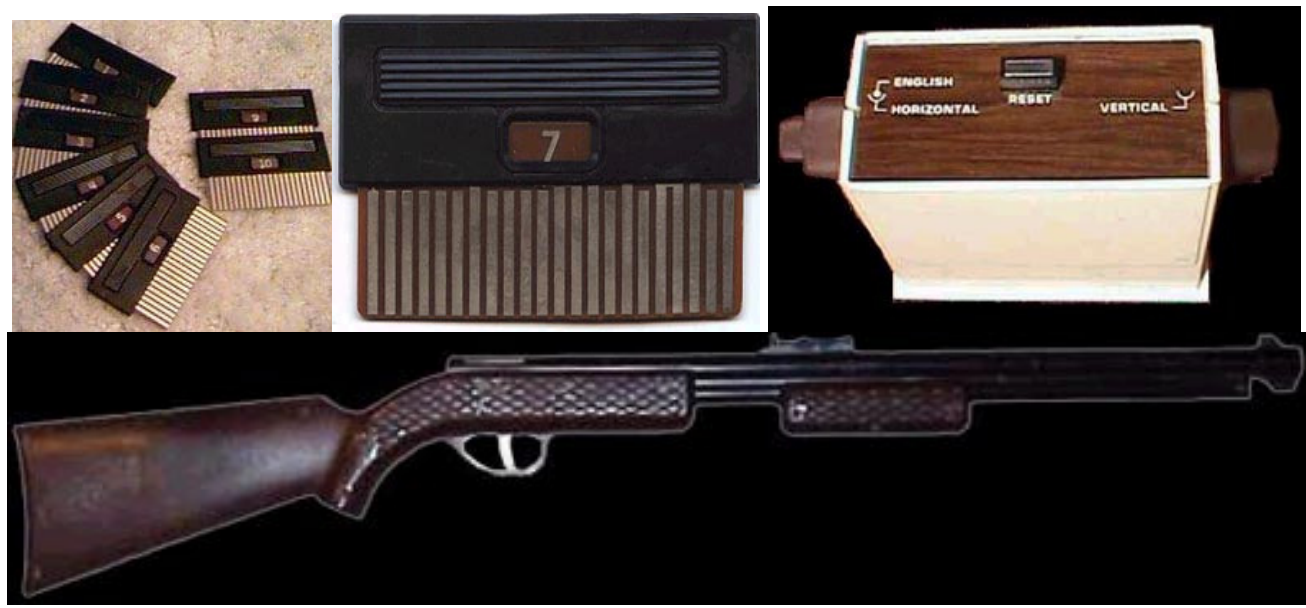

Ilustração 7 - Interfaces do Odyssey 100: os jumpers, o controle e o rifle Fonte: http://outerspace.ig.com.br/retrospace/ (Acesso em: 23 dez.2008)

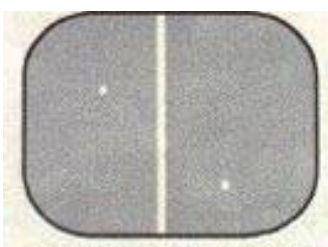

TABLE TENNIS. The basic Odyssey game that develops
your electronic coordination.

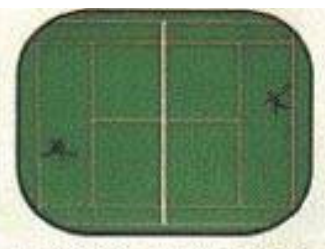

TENNIS. Alt the excitement of Wimaledon as you serve. vol ley and scote.

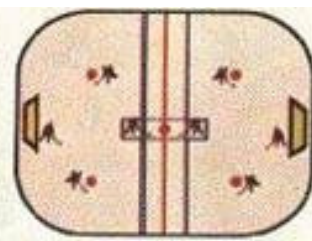

HOCKEY. Face-off, dig for the net, maneuver the puck goall

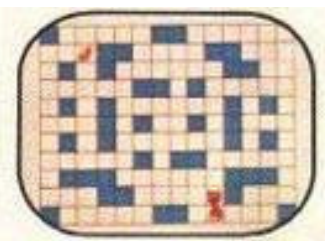

CAT AND MOUSE, Can the clever mouse oudo the can tantercus cat? A hilaricus oloc. tronic addition game of hice and seek

llustração 8 - Exemplo dos cartões plásticos colocados na televisão para compensar o fraco desempenho gráfico do Odyssey 100

Fonte: http://outerspace.ig.com.br/retrospace/ (Acesso em: 23 dez.2008) 
O grande sucesso comercial dos games começa quando o engenheiro eletrônico Nolan Bushnell, também no começo dos anos 70, adaptou a idéia do Spacewars! para uma versão fliperama (máquina única que combina processador, tela e controles), conhecida como Computer Space. Em 1972, fundava a Atari que, com o fliperama Pong, muito bem recebido pelo público por sua diversão e simplicidade, alcança o sucesso. O passo seguinte foi se transformar em console caseiro e aí surgiram várias empresas desenvolvendo diferentes versões e plataformas do Pong. Começava, nos meados da década de 70, a guerra das empresas de videogames.

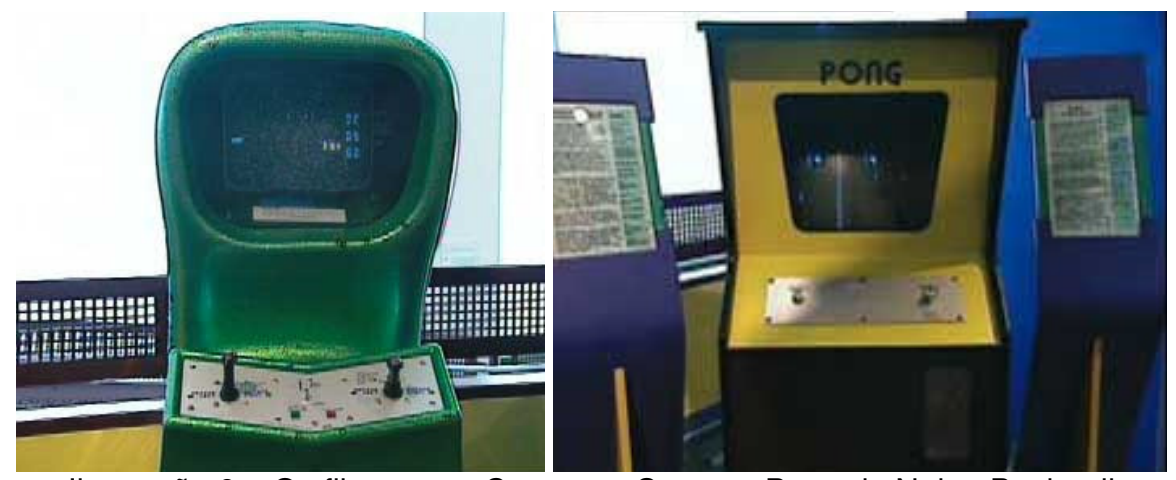

llustração 9 - Os fliperamas Computer Space e Pong de Nolan Bushnell Fonte: http://outerspace.ig.com.br/retrospace/ (Acesso em: 23 dez.2008)
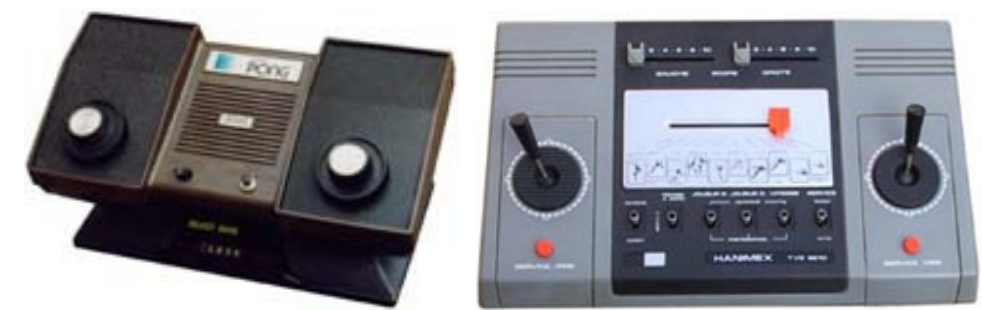

Ilustração 10 - O Pong doméstico e o similar Scomark 8 Sports Tele Fonte: http://outerspace.ig.com.br/retrospace/ (Acesso em: 23 dez.2008)

\subsection{2 - Segunda geração dos games: os consoles programáveis}

Em 1976 surgiu com o console Fairchild Channel F o primeiro videogame programável, onde os jogos eram condicionados em cartuchos trocáveis e comercializados individualmente. Mesmo passando quase despercebido no mercado dos videogames, com o Fairchild Channel F, propôs-se pela primeira vez a 
separação entre o hardware (console) e o software (jogos), inaugurando uma prática produtiva e mercadológica que existe até hoje.

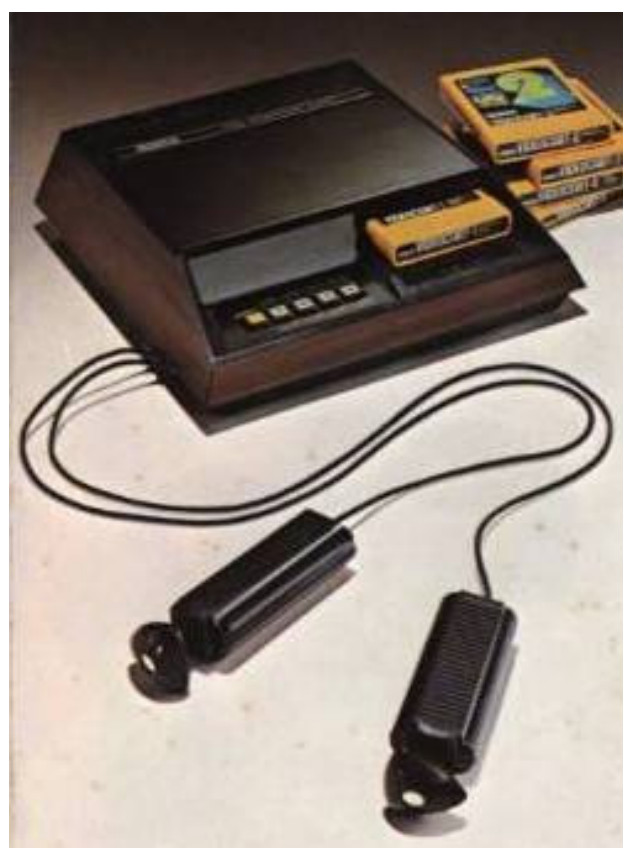

Ilustração 11 - Fairchild Channel F, o primeiro console programável Fonte: http://outerspace.ig.com.br/retrospace/ (Acesso em: 23 dez.2008)

Novos consoles surgem sob esse paradigma e no final de 1977 a Warner Communications, que comprara a Atari de Nolan Bushnell no ano anterior, lança o Atari 2600, o ícone de sucesso da indústria dos videogames. Um outro paradigma adotado na época que persiste até hoje foi a estratégia da Warner Communications de abrir a produção dos jogos para outros fabricantes de periféricos e softwares. Dessa forma, vários jogos foram lançados para alimentar as vendas estratosféricas do Atari 2600, no início dos anos 80, explorando seus respeitáveis 128 bytes de memória e 1.19 Mhz de velocidade do processador e da placa de vídeo

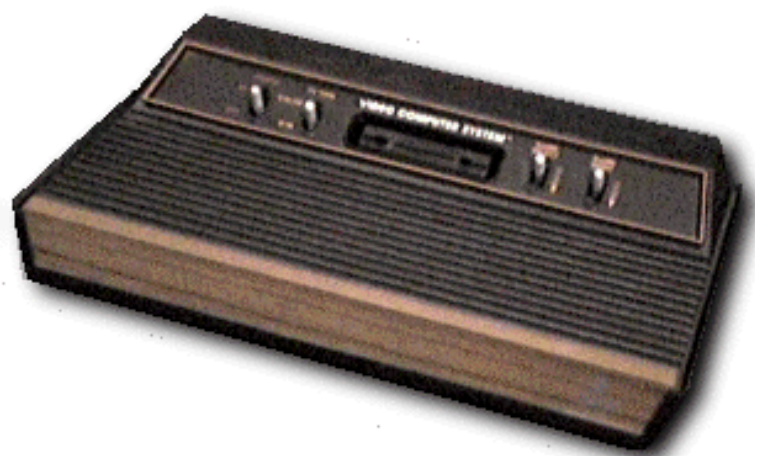

Ilustração 12 - Atari 2600, sucesso de vendas no começo dos anos 80 Fonte: http://outerspace.ig.com.br/retrospace/ (Acesso em: 23 dez.2008) 

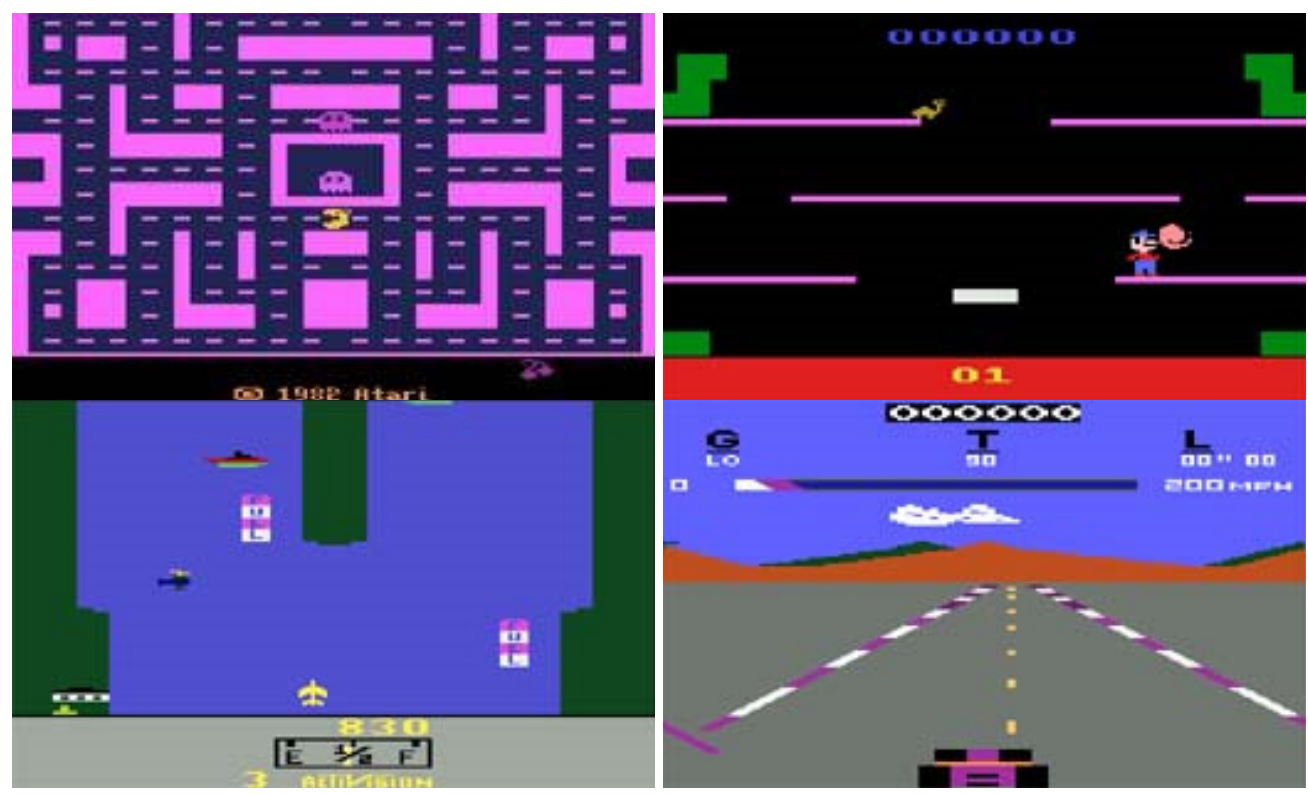

llustração 13 - Exemplos de jogos do Atari 2600 fabricados por diversas empresas Fonte: http://outerspace.ig.com.br/retrospace/ (Acesso em: 23 dez.2008)

Outro novo paradigma iniciado nessa época ocorre com o Microvision, lançado pela Milton Bradley, que inaugurava a produção dos consoles portáteis. O Microvision era constituído por baterias, tela de cristal líquido, cartuchos, controles e botões no próprio aparelho (como acontece nos portáteis até hoje). Não teve sucesso de vendas pela limitada quantidade de jogos oferecidos, mas se torna importante como conceito de portabilidade e mobilidade.
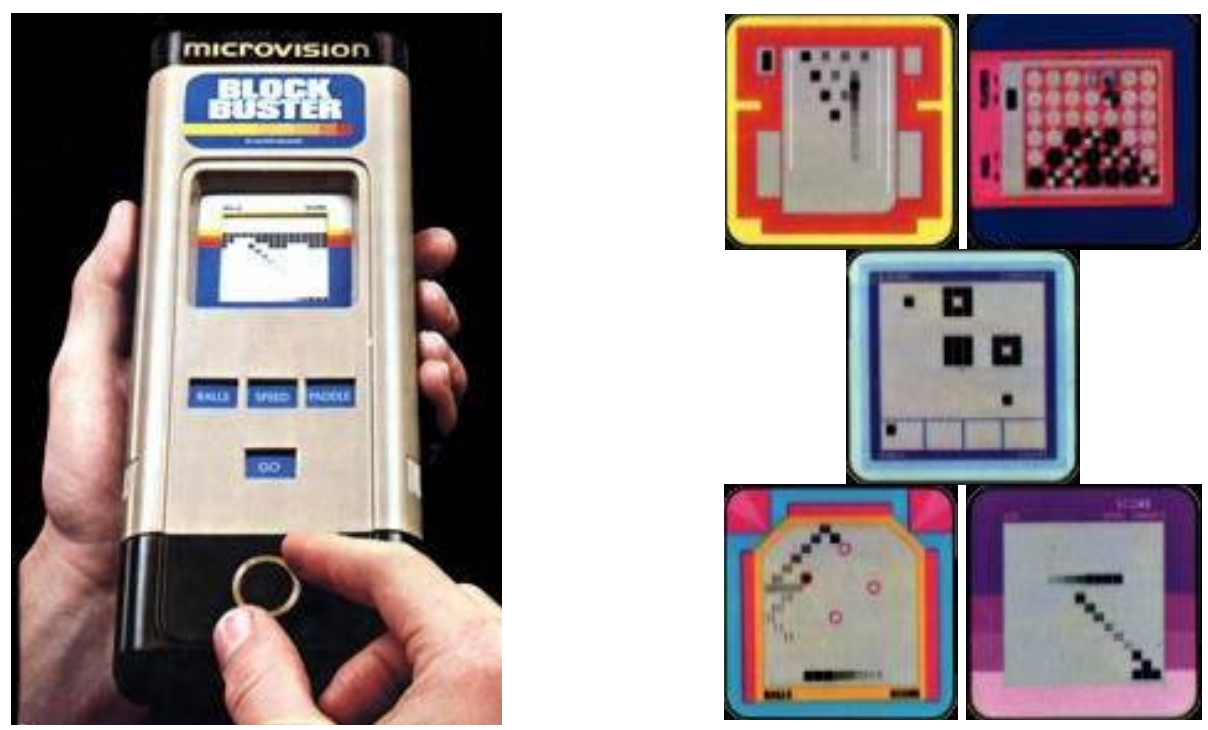

Ilustração 14 - Microvision, o primeiro console portátel e exemplos de jogos Fonte: http://outerspace.ig.com.br/retrospace/ (Acesso em: 23 dez.2008) 


\subsection{3 - Terceira geração dos games: entre computadores e brinquedos}

No final dos anos 70 e começo dos 80 , o mercado americano foi inundado por vários consoles e jogos que, em uma corrida tecnológica desorganizada, acaba abalando a própria qualidade das novas plataformas. A qualidade artística e lúdica dos jogos tinham pouca variação o que acabava comprometendo a cultura de consumo de videogames ao ponto de haver um "crash" de estagnação no mercado americano dos videogames em 1984, levando várias empresas a passar por profundas crises e até pedir falência, em alguns casos.

Ao mesmo tempo, havia uma euforia em relação aos computadores pessoais. Um acordo entre as empresas Microsoft (EUA) e Ascii (Japão) resulta no desenvolvimento de um computador pessoal de relativo baixo custo, que utilizava as televisões comuns (e não os caros monitores específicos), potente e com flexibilidade para expansões, o MSX, que passou a fazer concorrência direta com os IBM PCs, os únicos da época. Apesar do foco ser as possibilidades computacionais, os jogos já estavam impregnados na tecnologia e a configuração do computador MSX (consorciado por várias empresas) permitia o desenvolvimento de games com melhor qualidade gráfica e também melhor desempenho de jogabilidade, ou seja, com melhor controle, interatividade e desafio. Inaugura-se o casamento perpétuo entre videogames e computadores.

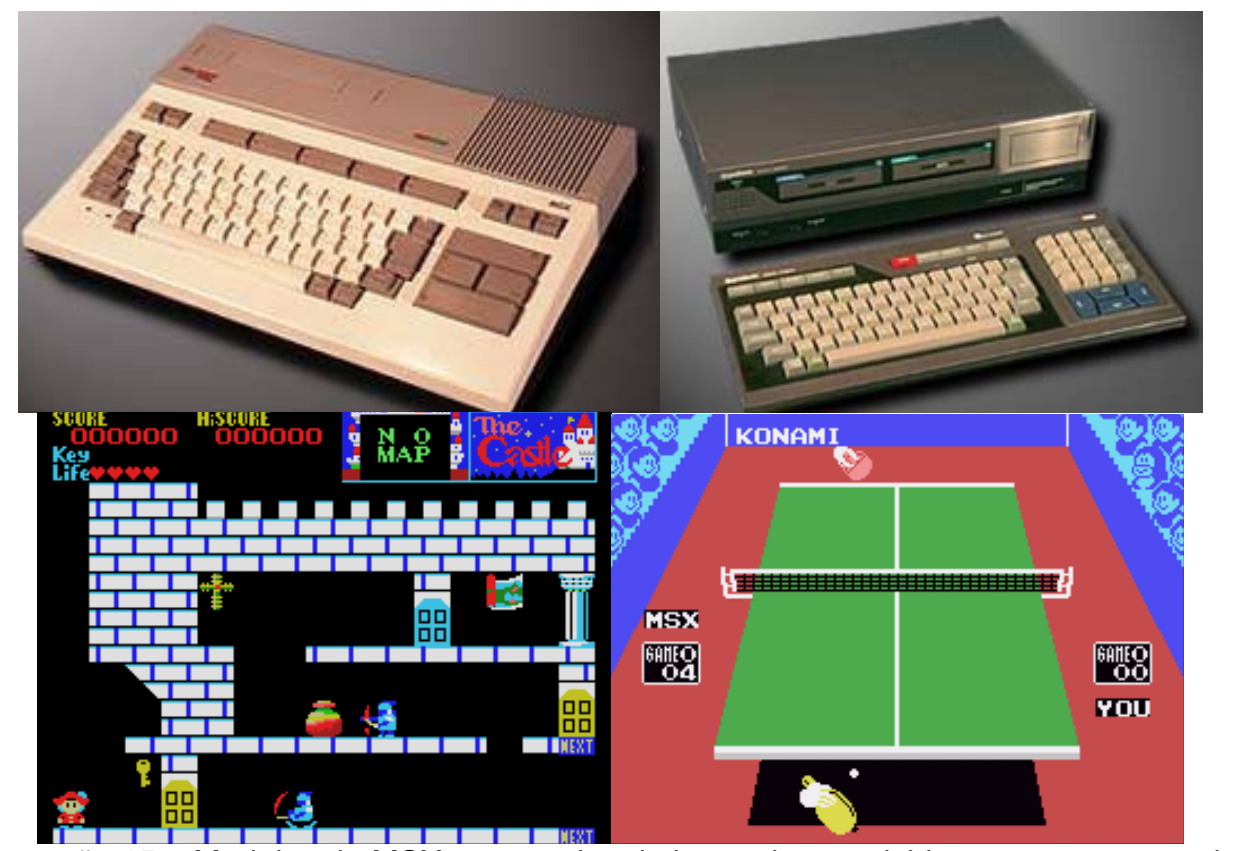

Ilustração 15 - Modelos do MSX e exemplos de jogos desenvolvidos para o computador Fonte: http://outerspace.ig.com.br/retrospace/ (Acesso em: 24 dez.2008) 
No caso do mercado brasileiro que se despertava para o consumo de computadores, havia limitações para a importação do MSX por questões legais de reserva de mercado sobre computadores. Algumas empresas brasileiras decidiram, então, anunciar o MSX como videogame ao invés de computador. A Gradiente, por exemplo, produzia em Manaus um módulo conhecido como Expert sem teclado, com dois slots para cartucho e dois joysticks (controles) para um console que, chegando ao consumidor final, se adicionava um teclado para compor um computador completo. A tecnologia do MSX foi, portanto, sucesso no Brasil na década de 80 tanto para jogos como para outros usos computacionais.

Nos EUA, se o mercado de videogames estava em crise, o Japão começava a despontar na indústria da ludicidade eletrônica. A empresa Nintendo, até então produtora de vários jogos clássicos para os diversos consoles, lançou o Famicom (Family Computer) com design estratégico que remetia a um brinquedo infantil e com o processamento de 8 bits. Para o mercado cético americano, a Nintendo remodelou o design para se aproximar mais de um robusto computador, alterou o nome para NES (Nintendo Entertainment System) e seu sucesso reacendeu o consumo dos videogames. Além dos melhores gráficos e da boa jogabilidade o NES contou com expansões opcionais de interface como a pistola, a luva Power Glove (que possibilitava uma interação de realidade virtual) e o robô R.O.B. (Robotic Operating Buddy) que deu uma "cara", ou um aspecto andróide ao console.
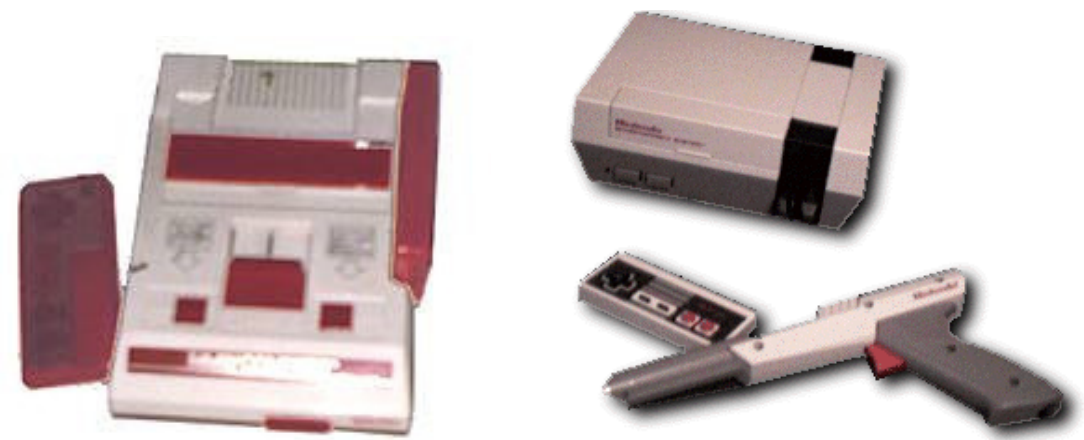

Ilustração 16 - O design de brinquedo do japonês Famicom e o NES, a versão americana do console da Nintendo

Fonte: http://outerspace.ig.com.br/retrospace/ (Acesso em: 24 dez.2008) 


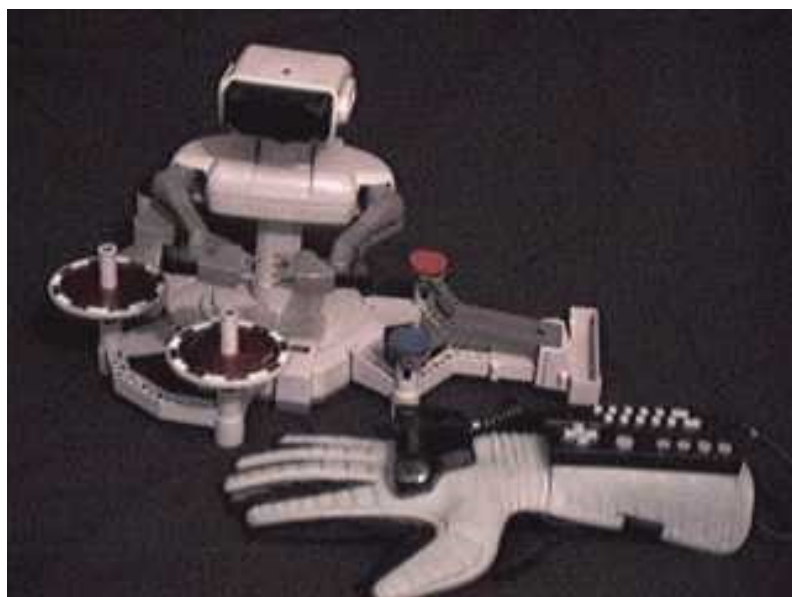

llustração 17 - Aposta em novas interfaces de interação para o NES Fonte: http://outerspace.ig.com.br/retrospace/ (Acesso em: 24 dez.2008)

A abertura para diversas softhouses poderem criar jogos para o NES despertou o mercado para o consumo de variados gêneros e tipos de jogos com enredos e jogabilidades diversos. Se antes os jogos se limitavam às plataformas casuais de esportes, carros, guerra espacial ou personagens em plataforma, agora, com uma infinidade de roteiros cinematográficos e desafios extremamente complexos e bem elaborados, os videogames passaram a promover e requisitar (em um círculo virtuoso) uma maior interatividade dos jogadores.

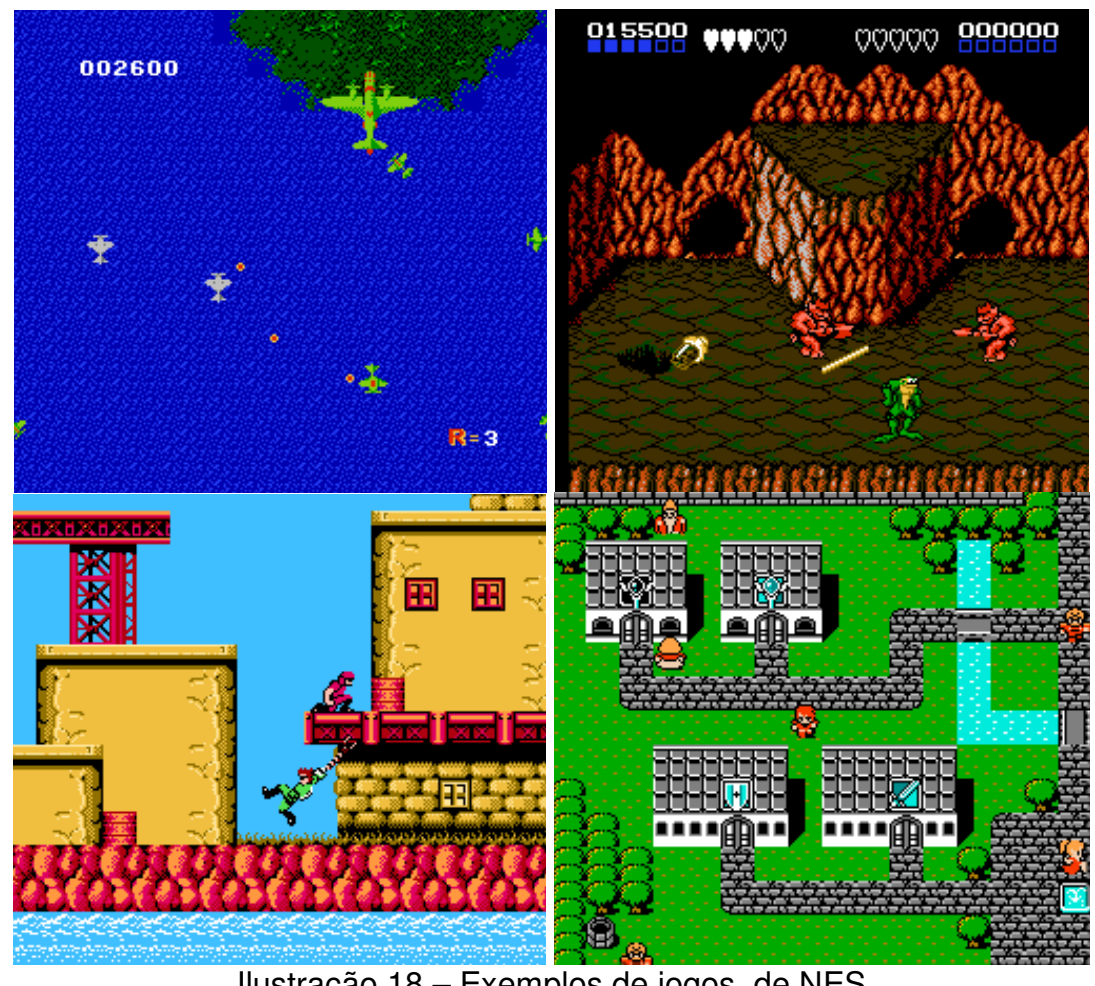

Ilustração 18 - Exemplos de jogos de NES

Fonte: http://outerspace.ig.com.br/retrospace/ (Acesso em: 24 dez.2008) 
A concorrência da Sega, com o Master System, e da Atari, com o Atari 7800, chegou tardiamente depois de três anos e, apesar de oferecer um sistema computacional mais sofisticado, não puderam disputar o domínio do NES de $90 \%$ do mercado no início dos anos 90, e que contava com jogos muito mais atrativos (resultado de pactos de exclusividade com as softhouses), além de estratégias de marketing muito sólidas e impactantes.

No Brasil, sem o lançamento oficial do NES, empresas importaram a tecnologia do console de 8 bits da Nintendo e lançaram plataformas alternativas. O primeiro "clone" foi o Dynavivion II da Dynacom que empregava o padrão japonês (do Famicom), lançado no Brasil em 1989. Para os compatíveis com o padrão americano, foram lançados o Bit System (da Dismac), o Hi-Top Game (da Milmar) e o Phantom System (da Gradiente) que, com o porte e eficiência da empresa, tornouse o principal alternativo nacional do console da Nintendo. Foi lançado, ainda, o Top Game VG 9000 da CCE, que suportava tanto o padrão americano quanto o japonês. Vale notar que o NES chegava timidamente no Brasil através de importações até o momento em que a Atari descobriu como burlar o chip de bloqueio do console para lançar jogos não autorizados sob a marca Tengen - com jogos próprios e cópias "piratas" de vários sucessos - intensificando a procura pelo videogame de 8 bits da Nintendo passou.

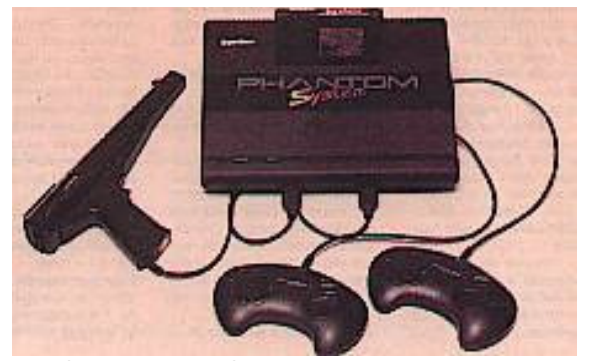

Ilustração 19 - O Phantom System da Gradiente - clone brasileiro do NES da Nintendo Fonte: http://outerspace.ig.com.br/retrospace/ (Acesso em: 31 dez.2008)

Mesmo com tais sistemas alternativos do NES, existia uma verdadeira procura pelo Master System da Sega, lançado oficialmente pela Tec Toy. O console encontrara um público periférico do cirtcuito EUA-Japão-Europa ávido por ludicidade eletrônica. Vários jogos adaptados para a cultura brasileira foram lançados a fim de fidelizar os gamers tupiniquins. Dessa forma, o público brasileiro foi servido por jogos estilizados e adaptados, a preços acessíveis e os consoles da terceira geração de games popularizaram o hábito de consumir os videogames no Brasil. 


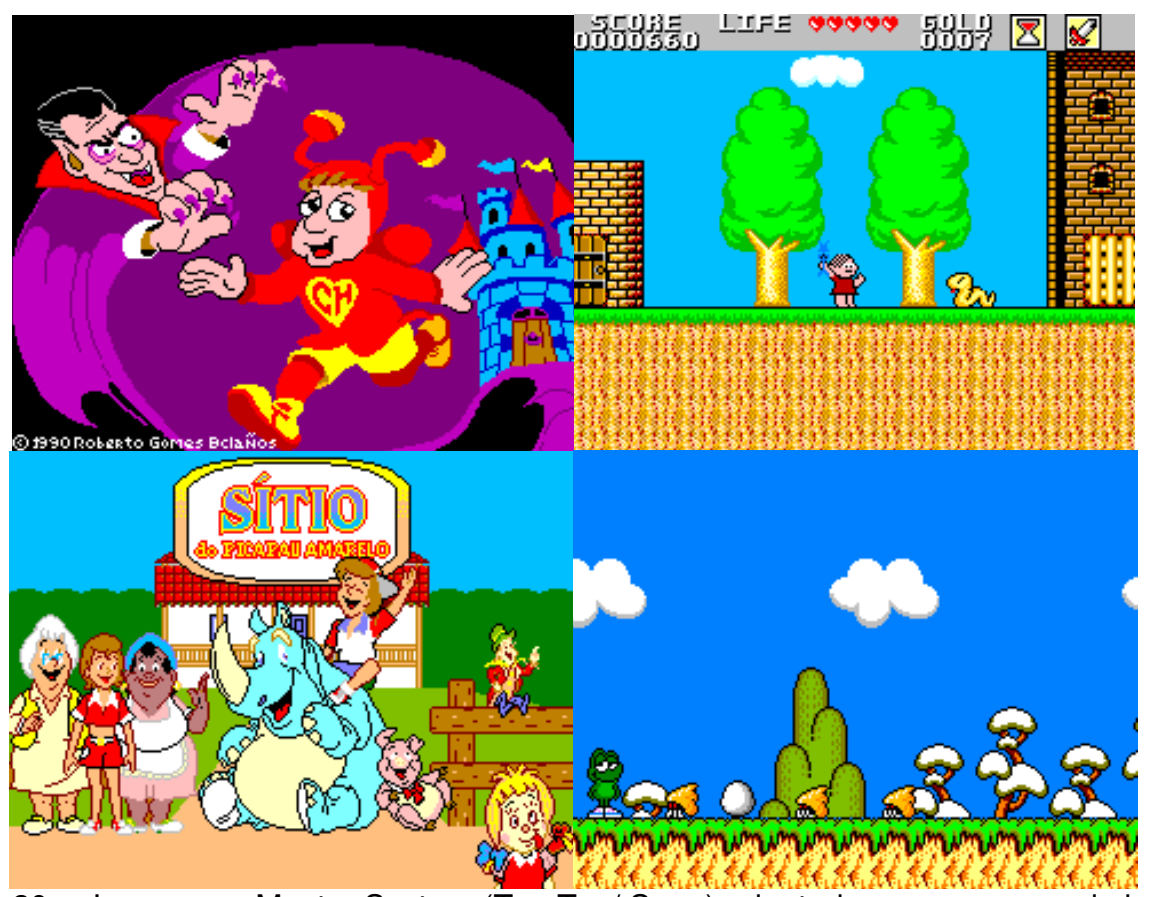

Ilustração 20 - Jogos para Master System (Tec Toy/ Sega) adaptados para o mercado brasileiro Chapolin, Turma da Mônica, Sítio do Pica-pau Amarelo e Sapo-Chulé

Fonte: http://outerspace.ig.com.br/retrospace/ (Acesso em: 24 dez.2008)

\subsection{4 - Quarta geração dos games: consolidação dos videogames}

No início dos anos 90 o mercado dos games sofriam questões judiciais com o embate sobre os direitos autorais, polêmica de acordos de exclusividade e monopólio, guerras judiciais de plágio e pirataria de jogos. Para sobreviver a esses embates, várias empresas dos jogos eletrônicos se reduziram para o plano de softhouses dispensando a disputa da produção de consoles deixando $O$ desenvolvimento da tecnologia dos hardwares nas mãos de poucas empresas. A gigante japonesa dos eletrônicos NEC lançou o PC Engine (Turbografx 16 nos EUA) - seu primeiro console de videogame - com tecnologia de processamento e gráfica baseadas nos 16 bits de lógica. Apesar dos seus recursos e dos periféricos de extensão de interatividade e de seu relativo sucesso no Japão, o PC Engine não contagiou o mercado americano pela fraca campanha de marketing e atraso de lançamento de bons jogos. Mesmo assim, o PC Engine, ao utilizar hibridamente o cartucho e CD-ROM, abriu o universo dos games para o uso das mídias populares (no caso o Compact Disc, passando pelo DVD e até Blu-Ray, nos consoles mais recentes), barateando e disseminando a possibilidade de criação de jogos. 


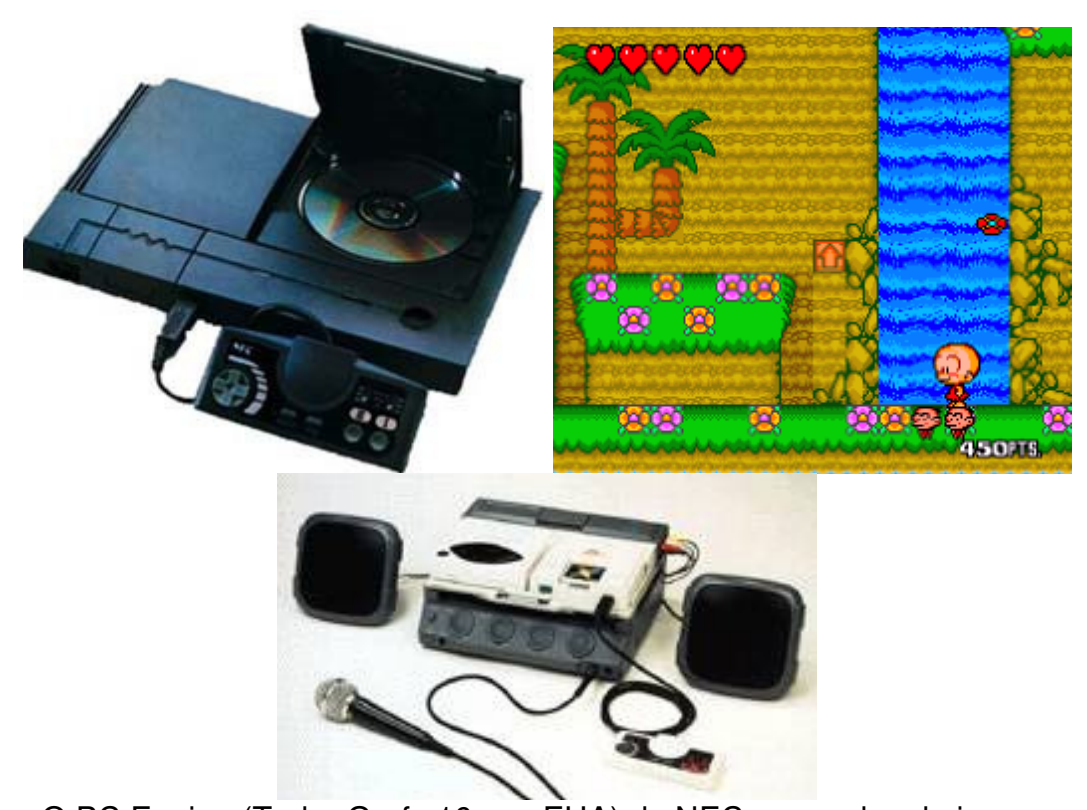

llustração 21 - O PC Engine (Turbo Grafx 16 nos EUA) da NEC, exemplos de jogos e periféricos e o uso do CD como plataforma de jogos

Fonte: http://outerspace.ig.com.br/retrospace/ (Acesso em: 28 dez.2008)

Destaques indiscutíveis do mercado da época, o Super NES da Nintendo e o Mega Drive (Gênesis nos EUA) da Sega, inauguraram o uso dos 16 bits de lógica de processamento. A melhoria de qualidade gráfica e de complexidade da lógica de enredo, interface e jogabilidade impressionaram um mercado ávido por inovações e consolidaram os videogames como sonho de consumo e como espécie tecnológica integrante da sociedade. Outro componente importante foi o Game Genius, lançado pela Galoob Toys para o Mega Drive que permitia ao jogador mexer na própria lógica do jogo, alterando os atributos dos personagens (vida, arma, poder, etc.), inaugurando o cheating code, ou seja, códigos de hackeamento dos jogos.

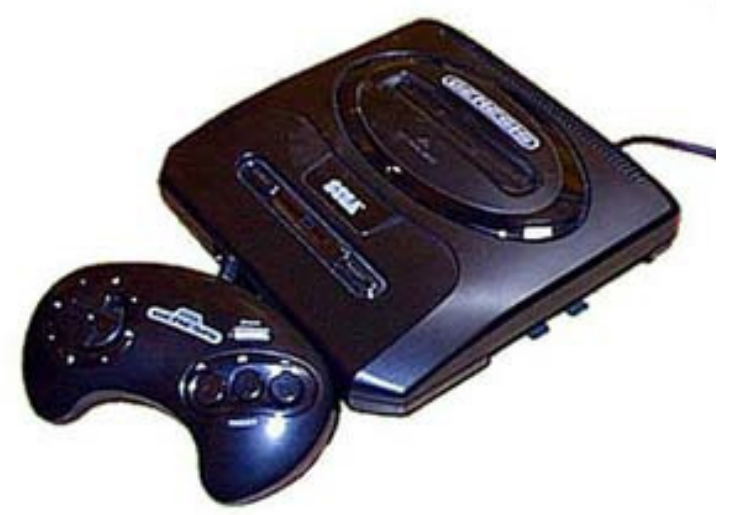

Ilustração 22 - O Mega Drive (Gênesis nos EUA) da Sega

Fonte: http://outerspace.ig.com.br/retrospace/ (Acesso em: 28 dez.2008) 

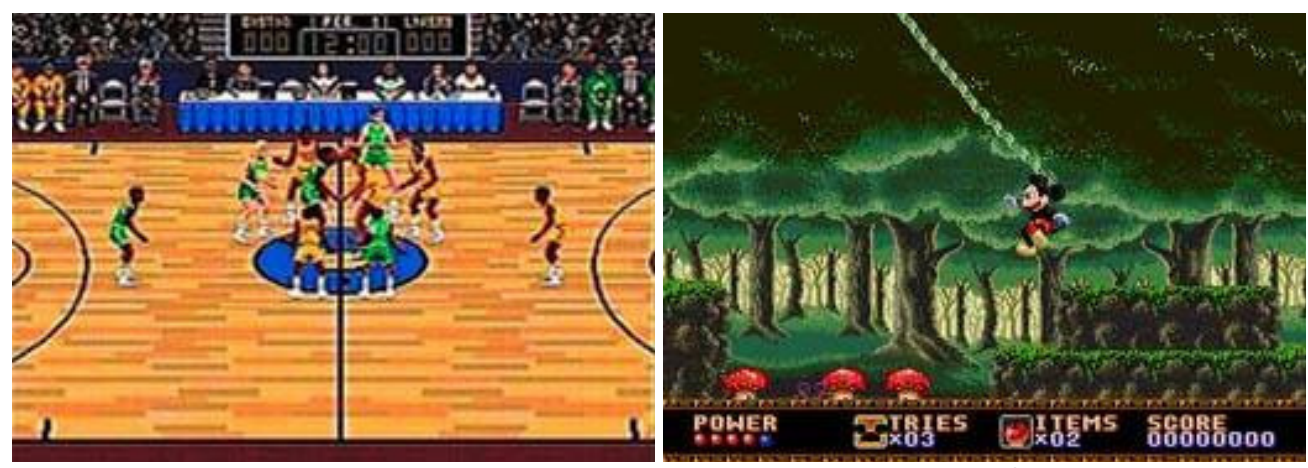

Ilustração 23 -Exemplos de jogos do Mega Drive da Sega

Fonte: http://outerspace.ig.com.br/retrospace/ (Acesso em: 28 dez.2008)

Destacou-se do Super NES o uso de chips Super FX para o processamento gráfico, que permitiam a implementação poligonal de elementos em 3D. Nasceu assim o embrião da lógica tridimensional na produção dos jogos que revolucionou não só o universo dos games, mas do desenho animado, do cinema e das artes gráficas, de modo geral.
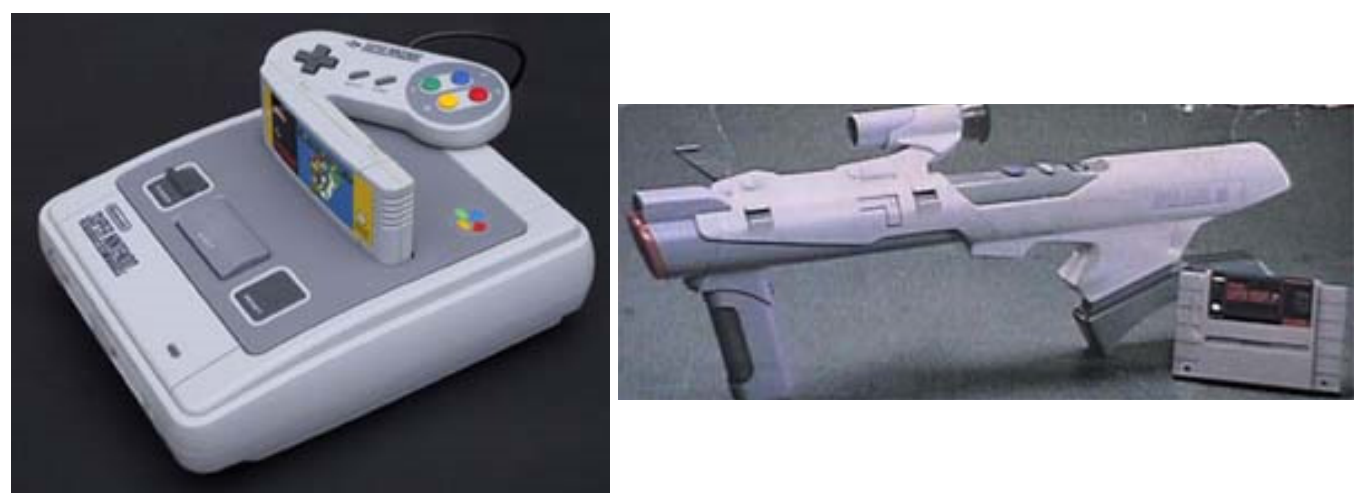

Ilustração 24 - O Super NES (Super Famicom no Japão) da Nintendo e bazuca opcional Fonte: http://outerspace.ig.com.br/retrospace/ (Acesso em: 28 dez.2008)
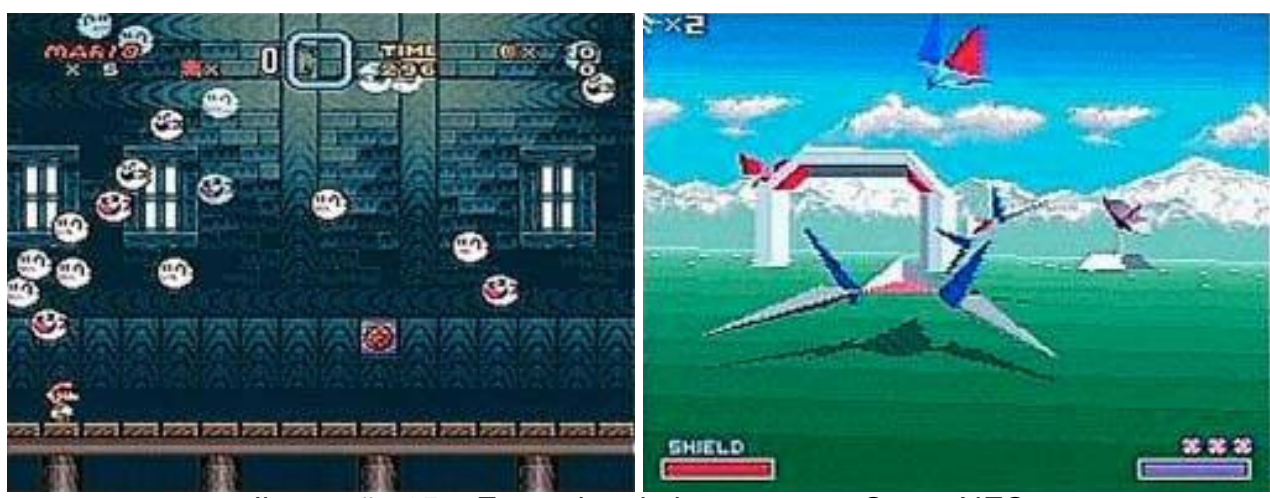

Ilustração 25 - Exemplos de jogos para o Super NES

Fonte: http://outerspace.ig.com.br/retrospace/ (Acesso em: 28 dez.2008) 
O Super NES foi considerado um sucesso de mercado, com mais de 50 milhões de unidades vendidas em todo o mundo e contendo um catálogo de jogos considerado excelente tanto em quantidade como em qualidade. Com isso, a Nintendo conseguiu aumentar o público consumidor dos games domésticos. No Brasil, o Super NES foi lançado oficialmente em 1993 pela Playtronic e passou a ser produzido pela Gradiente.

Mas a grande inovação nessa geração não se limitou ao linear e natural desenvolvimento tecnológico dos consoles, pois foi o surgimento e a consolidação do novo paradigma - as plataformas portáteis de ludicidade eletrônica. A partir do Microvision da Milton Bradley, nos anos 80 e muito antes do consumo dos celulares ou dos PDAs (Personal Digital Assistants - os computadores de bolso), os games promoveram a atração pelas tecnologias portáteis do Japão para o resto do mundo através do Game Boy da Nintendo, lançado em 1989. Sucesso absoluto e imediato de vendas no mundo, o Game Boy, apesar da tela monocromática, se destacou pelos jogos de qualidade e de atração garantidas pelas franquias já instauradas no NES e Super NES.

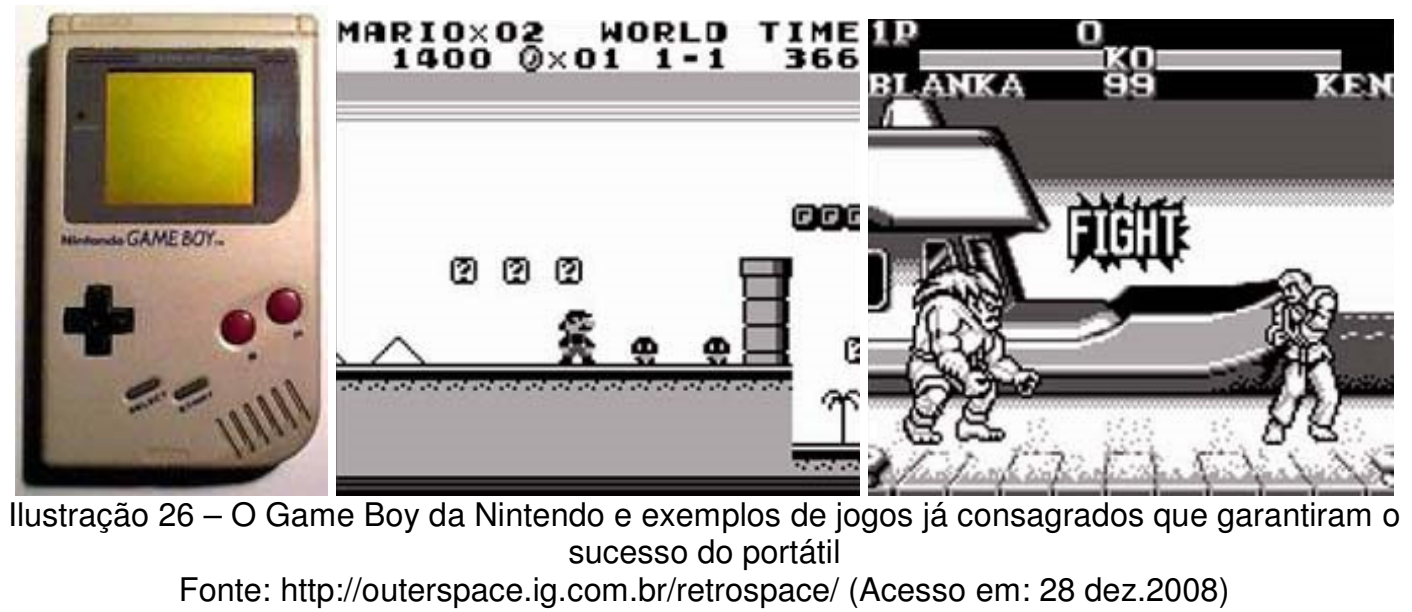

Fortalecendo o sucesso do Game Boy e inaugurando um novo paradigma dos portáteis, a Nintendo e várias outras empresas passaram a desenvolver periféricos de extensão para o console elevando o seu potencial de interação e ultrapassando o seu uso como brinquedo casual. Destacaram-se periféricos como uma câmera, impressora, agenda eletrônica e até um sonar para pesca. Outros periféricos surgiram para integrar o Game Boy a outros consoles como o Super NES e Mega Drive. 

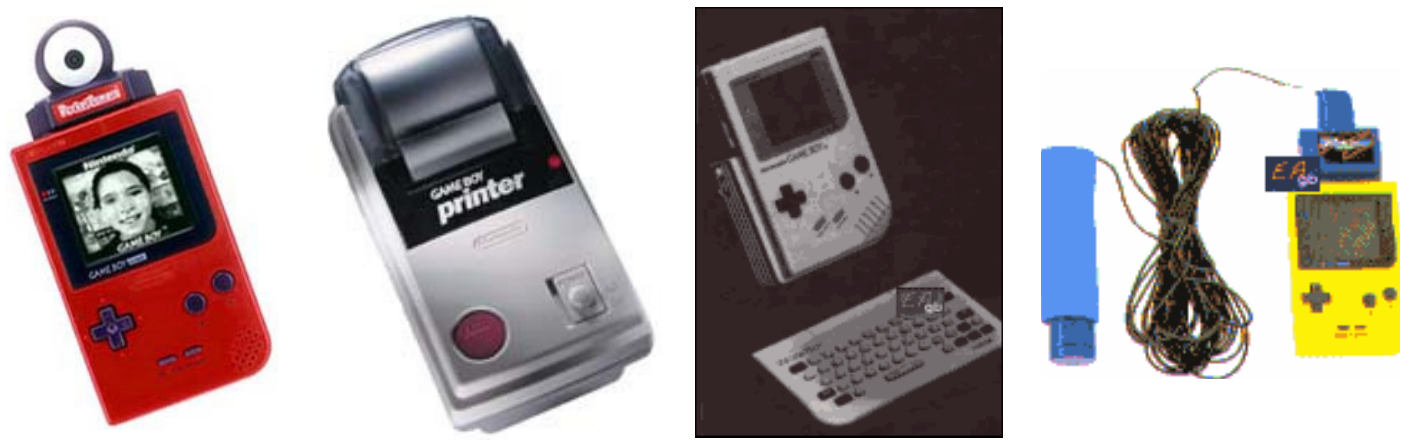

Ilustração 27 - Periféricos opcionais do Game Boy que extenderam seu uso: câmera fotográfica, impressora, teclado e memória para agenda eletrônica e sonar para pesca (detecta cardumes) Fonte: http://outerspace.ig.com.br/retrospace/ (Acesso em: 28 dez.2008)

Vale notar que a Atari, a Nec e a Sega, logo após o lançamento do Game Boy, lançaram os concorrentes portáteis Linx, o PC Engine GT (Tubografx Express nos EUA) e o Game Gear, respectivamente, com tecnologias muito superiores ao portátil da Nintendo (telas coloridas, processadores próximos ao Super NES e até adaptador opcional de televisão). Mas, mais uma vez, contra o Linx da Atari e o Game Gear da Sega, a Nintendo conseguiu se garantir através da qualidade dos jogos e o primor tecnológico se viu subjugado (ou pelo menos atrelado) às qualidades de arte e jogabilidade.
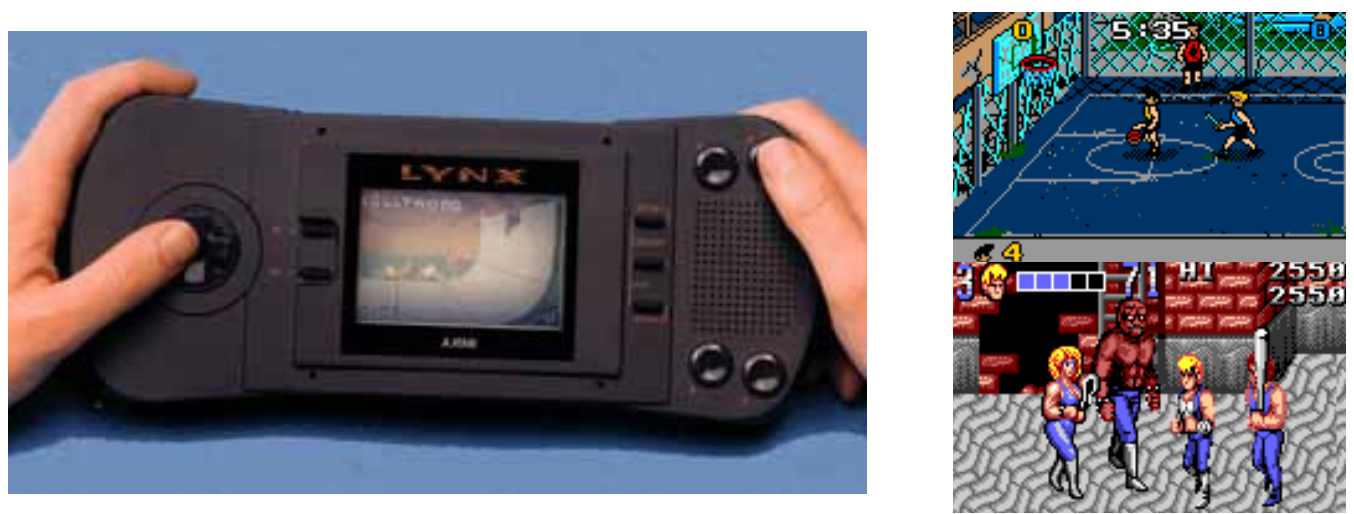

Ilustração 28 - O portátil Linx da Atari que, apesar da superioridade tecnológica em relação ao Game

Boy da Nintendo, não tinha bom catálogo de jogos e fracassou mercadologicamente Fonte: http://outerspace.ig.com.br/retrospace/ (Acesso em: 28 dez.2008) 

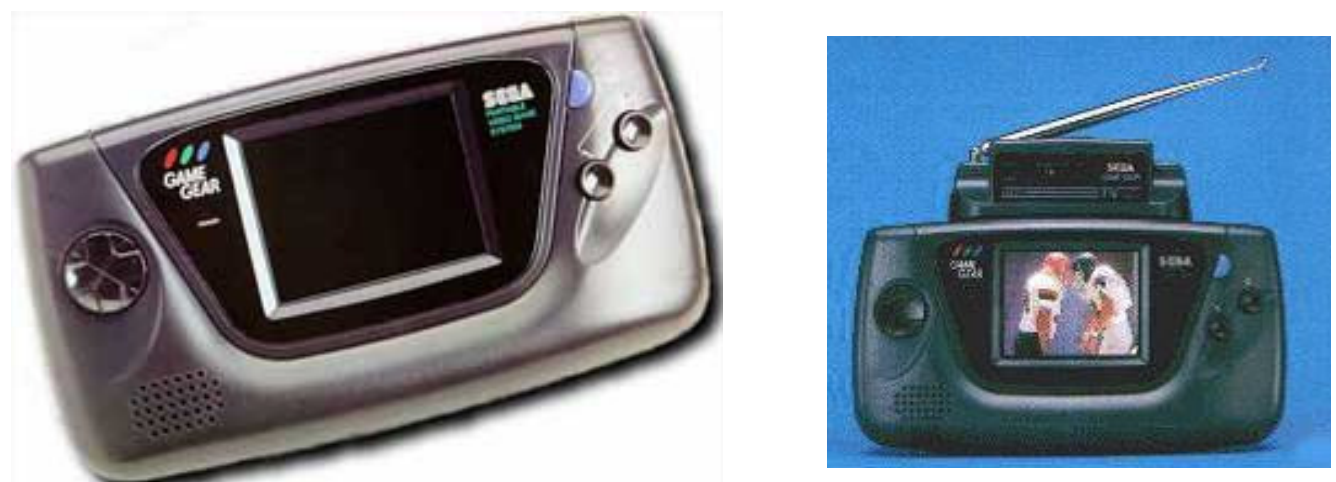

llustração 29 - O portátil Game Gear da Sega, muito caro em relação ao Game Boy da Nintendo e sem jogos exclusivos, não emplacou nas vendas

Fonte: http://outerspace.ig.com.br/retrospace/ (Acesso em: 28 dez.2008)

As incursões da NEC no universo dos games (tanto o PC Engine, quanto o PC Engine GT) contavam com excelentes jogos e tecnologias mas não tinham um bom plano de marketing para o mercado americano e seus preços extremamente altos não levaram à popularização de seus consoles. Conseqüentemente a empresa resolveu sair desse mercado tão disputado.

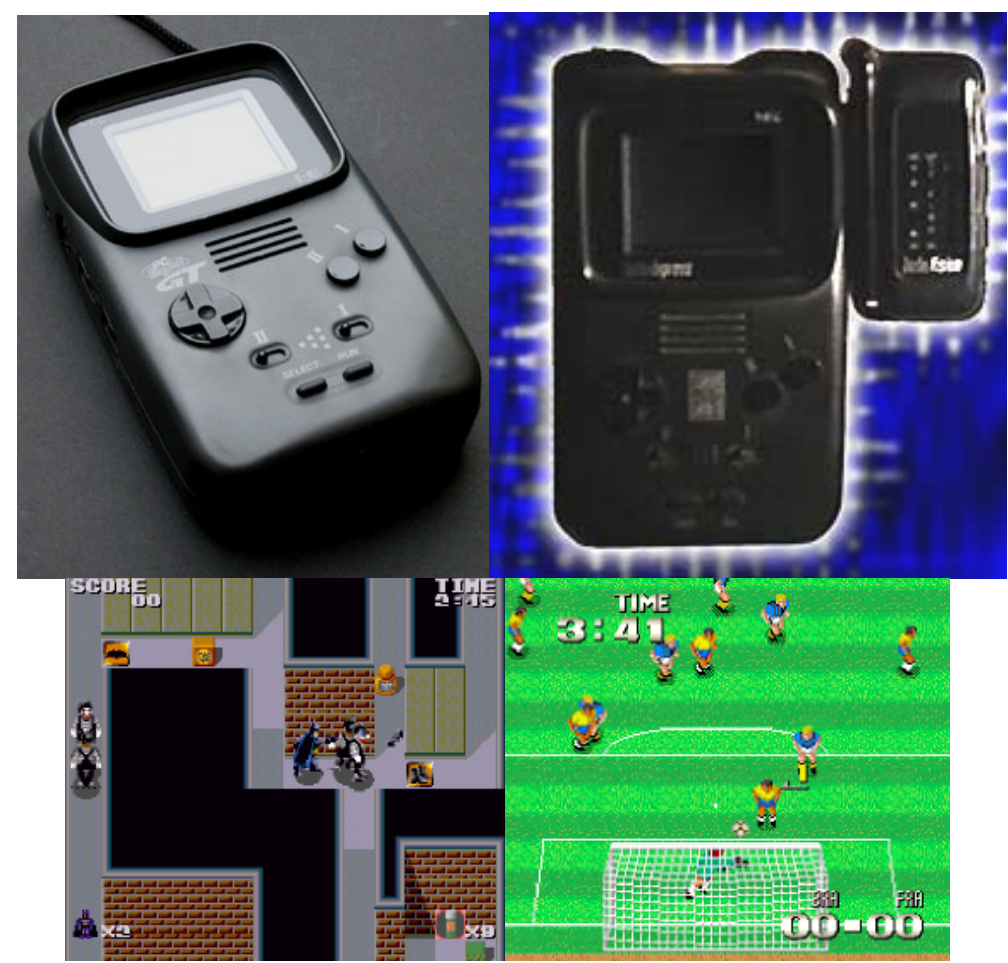

Ilustração 30 - O portátil PC Engine GT da NEC que, pelo preço excessivamente alto não se popularizou

Fonte: http://outerspace.ig.com.br/retrospace/ (Acesso em: 28 dez.2008) 


\subsection{5 - Quinta geração dos games: tecnologia para o lúdico}

No campo tecnológico, a principal inovação dos novos consoles lançados nos meados dos anos 90 foi a lógica tridimensional utilizada nos processadores gráficos e que inovaram a jogabilidade dos jogos, que passaram a conter modelos e cenários tridimensionais. Envolvendo tecnologias de lógica de 32 e 64 bits, a nova geração dos consoles focaram na tecnologia de realidade virtual para aprimorar os gráficos poligonais e, portanto, na composição de mundos tridimensionais complexos e completos.

O primeiro console da geração a ser lançado foi o Sega Saturn que, com 32 bits e 8 processadores, tinha bom desempenho e trabalhava com gráficos bidimensionais e tridimensionais. Para tanto, contava com uma arquitetura complicada e exigia que os produtores de jogos acompanhassem tal complexidade. Para a programação, ao invés de utilizar linguagens de alto nível (como o $\mathrm{C} / \mathrm{C}_{++}$) mais populares aos desenvolvedores de games, utilizava uma linguagem de baixo nível (próximo aos códigos binários - 0s e 1s - da máquina) em Assembly. Essa dificuldade de programação levou várias produtoras a migrar para o console da Sony, o Playstation, muito mais fácil de programar. Assim, apesar do bom desempenho, acervo de jogos baseados em franquias de sucesso dos consoles anteriores da Sega e de periféricos de expansão da interatividade, o Sega Saturn perdeu mercado para os concorrentes a médio prazo.

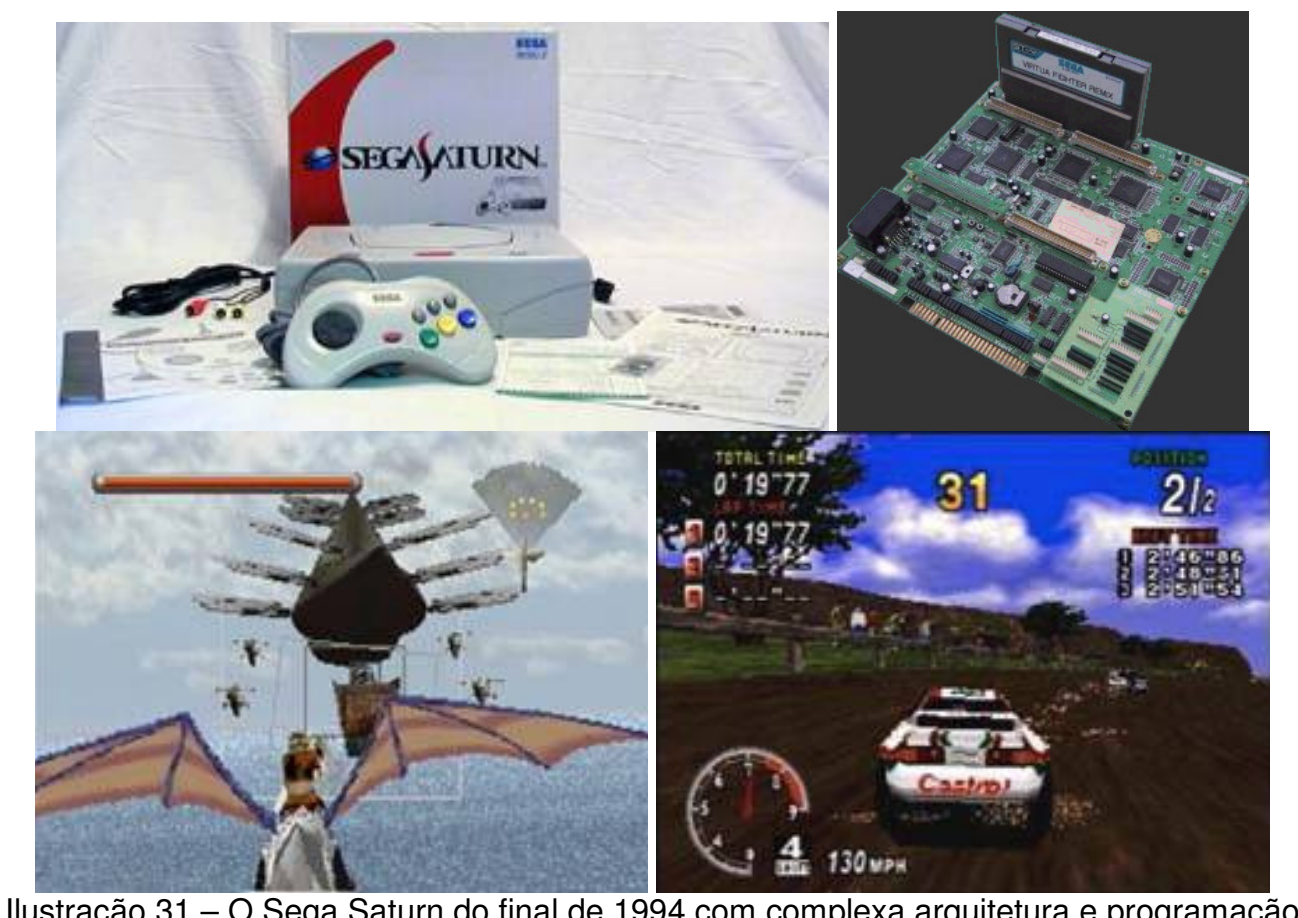


Fonte: http://outerspace.ig.com.br/retrospace/ (Acesso em: 28 dez.2008)

Inaugurando-se no universo dos consoles de games, a Sony lança o Playstation em dezembro de 1994. Fruto de um projeto frustrado de integração da tecnologia de CD-ROM com tecnologia da Sony para o Super NES da Nintendo, a companhia japonesa encontrou a oportunidade de lançar um console próprio e entrar no disputado mercado dos games. Dessa forma, o Playstation consolida as mídias populares do CD (Compact Disc) para o aporte dos seus jogos que foram desenvolvidos totalmente dedicados aos objetos poligonais, ou seja, para modelos e cenários tridimensionais. $O$ uso dos baratos CDs em contraponto aos caros cartuchos, permitiu a criação de jogos mais complexos compilados em mais de um disco e, portanto, muito mais elaborados graficamente e artisticamente. A dedicação total à lógica tridimensional dos objetos, cenários e personagens inaugurou uma prática no desenvolvimento de games sem retorno. O Playstation, apesar de ser 0 primeiro passo de um iniciante no mundo dos videogames, foi considerado o console mais bem sucedido pelas vendas (mais de 100 milhões de unidades) e pelos títulos (milhares de jogos, entre fracassos e franquias de sucesso). O console suportava um cartão de memória para salvar informações e status dos jogos. É importante notar que o uso do CD (extremamente popular e com possibilidade de cópias através de destravamento por chip) como mídia dos jogos, abriu espaço para a pirataria dos jogos (um dos principais aspectos do sucesso do console no Brasil).
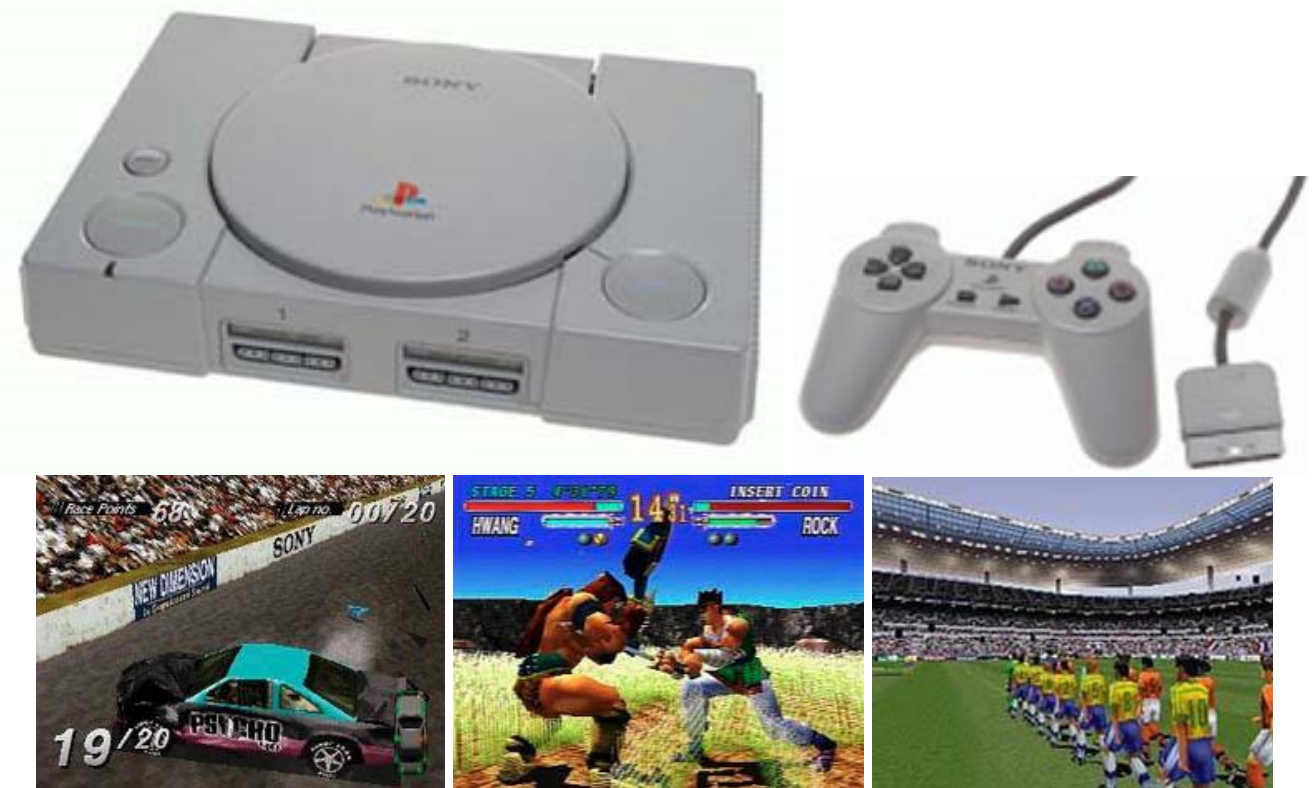

llustração 32 - O Playstation da estreante Sony no mundo dos games com jogos construídos totalmente na lógica tridimensional 
Fonte: http://outerspace.ig.com.br/retrospace/ (Acesso em: 28 dez.2008)

Tardiamente em meados de 1996 a Nintendo lançou o Nintendo 64, seu console de 64 bits ("pulando" a leva dos 32 bits) com tecnologia gráfica extremamente apurada e efeitos de otimização visual para cenários e personagens tridimensionais como o mip-mapping (borrado nas texturas) e anti-aliasing (correção dos contornos da imagem). Outra evolução foi em relação ao joystick que apresentava a revolucionária tecnologia analógica no controle direcional (um stick controlava as direções em vários ângulos e intensidades de força e velocidade), ideal para a interação com cenários tridimensionais. O grande problema do Nintendo 64 foi o obsoleto uso de cartuchos, que encarecia a produção e minimizava os lucros das produtoras de jogos, afugentando-as. Além disso, a capacidade de armazenamento de dados (32MB em um cartucho contra os 650MB de um CD) limitava as qualidades de mapeamento e dos sons, mesmo com um excelente processamento tridimensional.
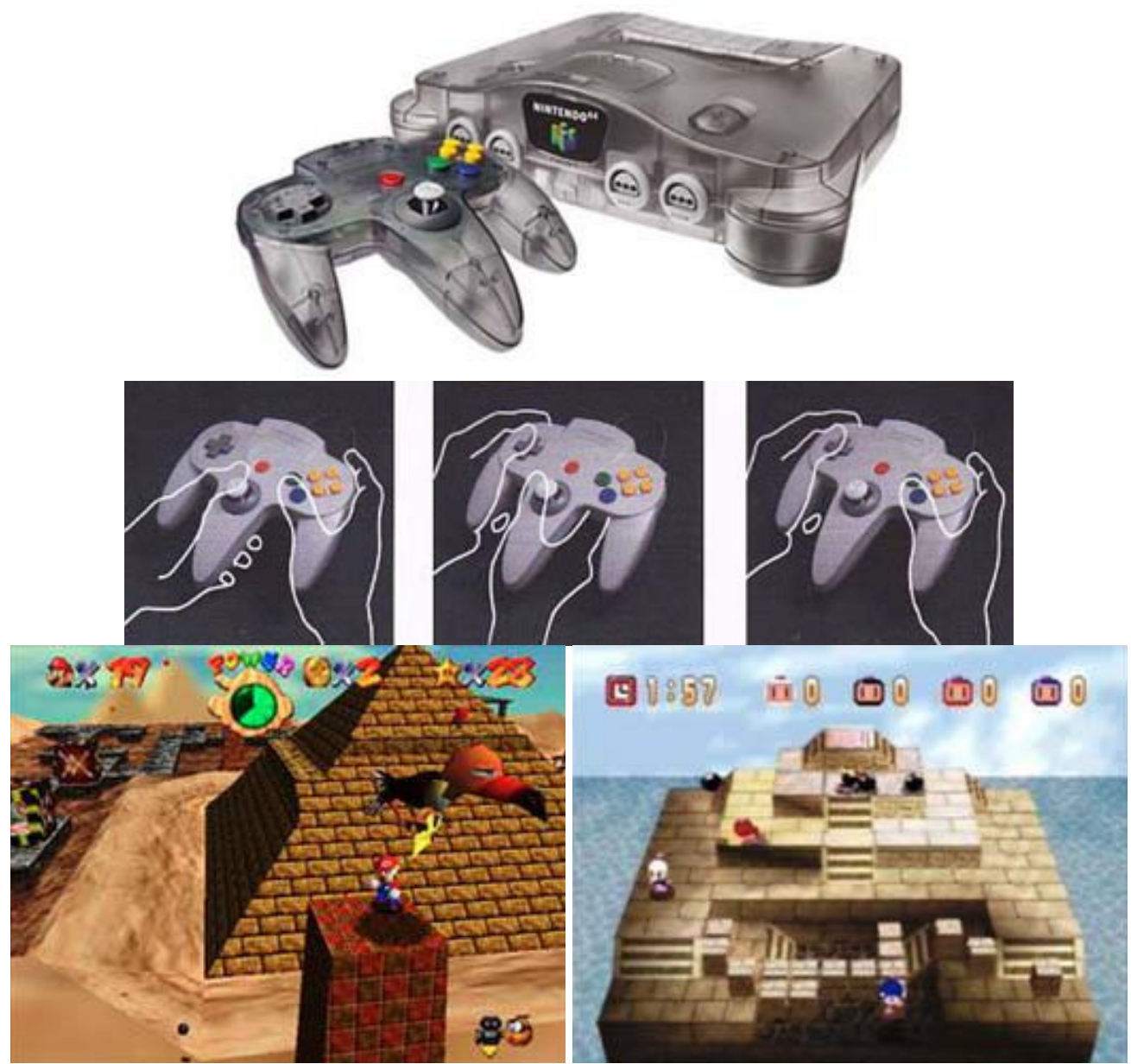

Ilustração 33 - O Nintendo 64 com ótimo desempenho gráfico, mas ainda com jogos distribuídos em cartuchos 
Fonte: http://outerspace.ig.com.br/retrospace/ (Acesso em: 28 dez.2008)

No campo dos portáteis, algumas experiências fracassadas não tiraram a hegemonia do Game Boy e de suas variações e ampliações. Do Nomad da Sega (espécie de adaptação da tecnologia do Mega Drive para uma plataforma portátil) até o Virtual Boy da própria Nintendo, ninguém conseguiu fazer frente ao Game Boy que em 1998 ganhou sua versão colorida no Game Boy Color e aproveitou o sucesso da franquia Pokémon. Mas o Virtua Boy, apesar do fracasso, apresentava uma tecnologia de imersão em realidade virtual que merecia destaque pelo visionário investimento nas tecnologias imersivas. Apesar da inovação baseada em óculos com imagens diferentes para cada olho (promovendo o efeito ótico de tridimensionalidade) e um controle, o portátil foi um fracasso de vendas pelo gráfico monocromático em vermelho e preto e pelos fracos jogos lançados para o console. Tal fracasso fez as ações da Nintendo despencar e quase comprometeu o sucesso do Nintendo 64 e da própria continuidade da empresa.

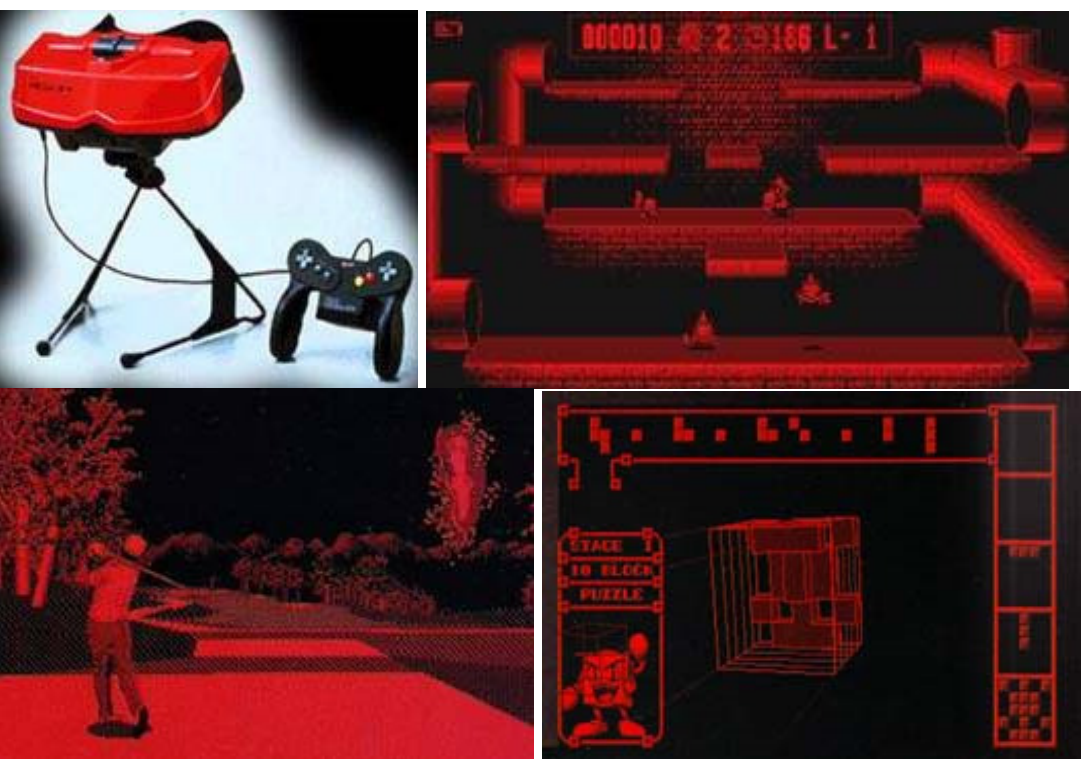

Ilustração 34 - O fracassado portátil Virtual Boy da Nintendo transportava a realidade virtual para o universo dos games comerciais

Fonte: http://outerspace.ig.com.br/retrospace/ (Acesso em: 28 dez.2008)

\subsection{6 - Sexta geração dos games: tecnologia do lúdico como carro chefe}

A partir da década de 90, para otimizar os custos de produção e aumentar o lucro no desenvolvimento e venda de jogos, as softhouses passaram a lançar os jogos para várias plataformas, incluindo versões para os PCs. Para suportar 0 processamento gráfico, empresas especializadas em placas gráficas (GPUs - 
Graphics Processing Unit) colocaram no mercado variados modelos popularizando o uso de tais componentes específicos para o cálculo gráfico. Além do processamento gráfico para os games, as placas otimizaram as renderizações de softwares gráficos de edição de imagem, edição de vídeo e animação 3D. De certa forma, os games demandaram o desenvolvimento tecnológico e ampliaram o uso dessas mesmas tecnologias, sendo o carro-chefe na popularização e na corrida tecnológica. Além do processador gráfico, os videogames popularizaram a tecnologia de armazenamento de data em mídias móveis. Começando pelo CD-ROMs, a sexta geração de videogames promoveu e barateou o uso dos DVD-ROMs e a nova e atual geração utiliza discos Blu-Ray e HD-DVD.

Especificamente sobre os games, a inovação está nos 128-bits e nas placas gráficas de alto desempenho (todas desenvolvidas especificamente para a construção poligonal de ambientes e objetos tridimensionais) que possibilitam a renderização em tempo real de personagens, arquiteturas e paisagens extremamente refinados, combinados com efeitos realísticos de partículas (vento, explosão, água, etc.). O sucesso gráfico foi acompanhado por diversos jogos complexos em seu enredo e com jogabilidade atraente.

O primeiro console a ser lançado com tal poder de fogo foi o Dreamcast da Sega, no final de 1998 (Japão) e 1999 (EUA). Além dos gráficos tridimensionais extremamente bem elaborados, o Dreamcast contava com um inovador controle onde se embutia um cartão de memória (para salvar os jogos) com um visor (que continha informações de status do personagem e onde se poderia jogar minigames) e um modem de 56kbps que permitia ao jogador acessar a internet e ter experiências de jogo online (teclado e mouse opcionais transformavam o console em ponto de acesso à internet), inaugurando a cultura dos jogos em rede. Um ponto negativo foi o uso de um disco exclusivo, o que encarecia a produção e distribuição dos jogos, afugentando algumas softhouses. Mas apesar do seu sucesso nos EUA, - Dreamcast foi o último console da Sega que, passando por crises financeiras, resolveu se dedicar à criação de jogos para os demais consoles. 


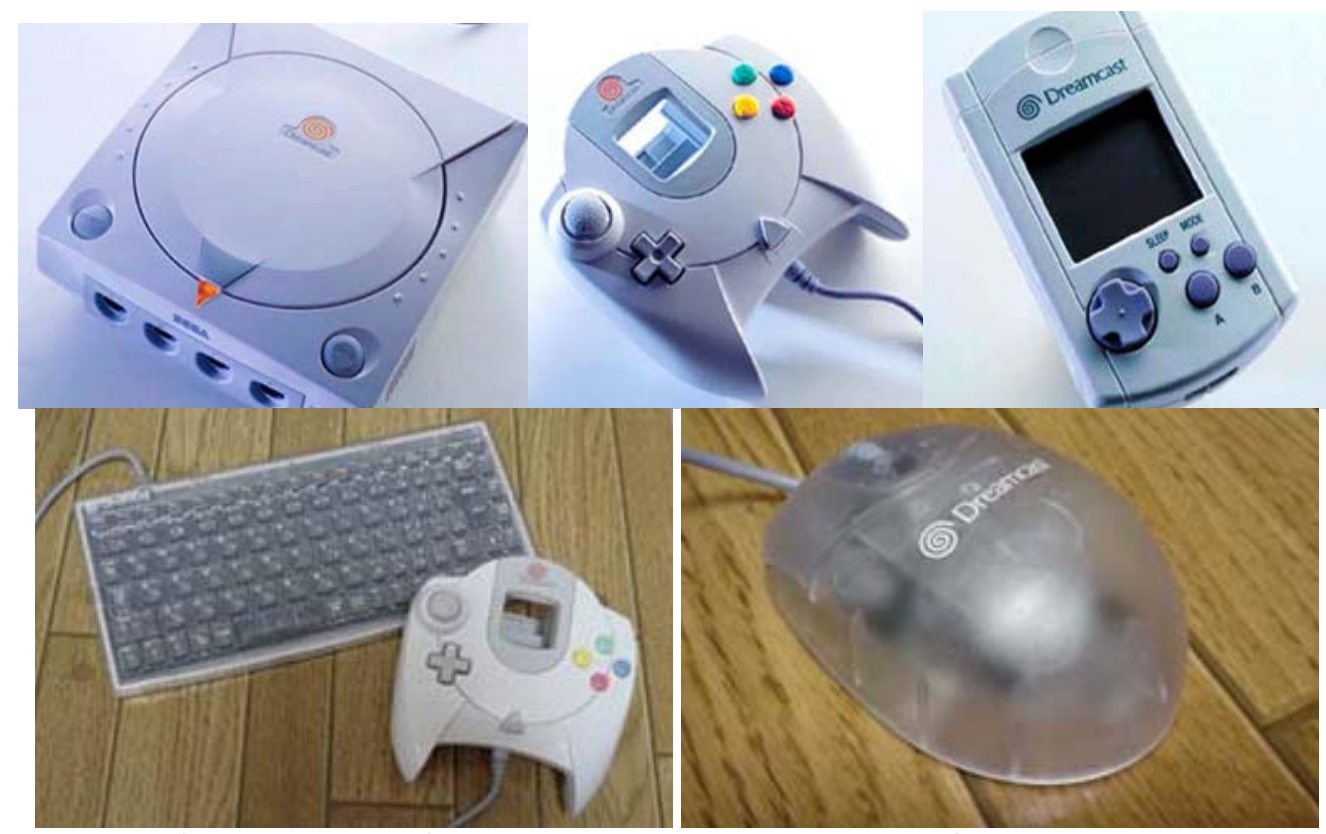

Ilustração 35 - O Dreamcast da Sega, seu controle e cartão de memória com visor, teclado e mouse Fonte: http://outerspace.ig.com.br/retrospace/ (Acesso em: 29 dez.2008)
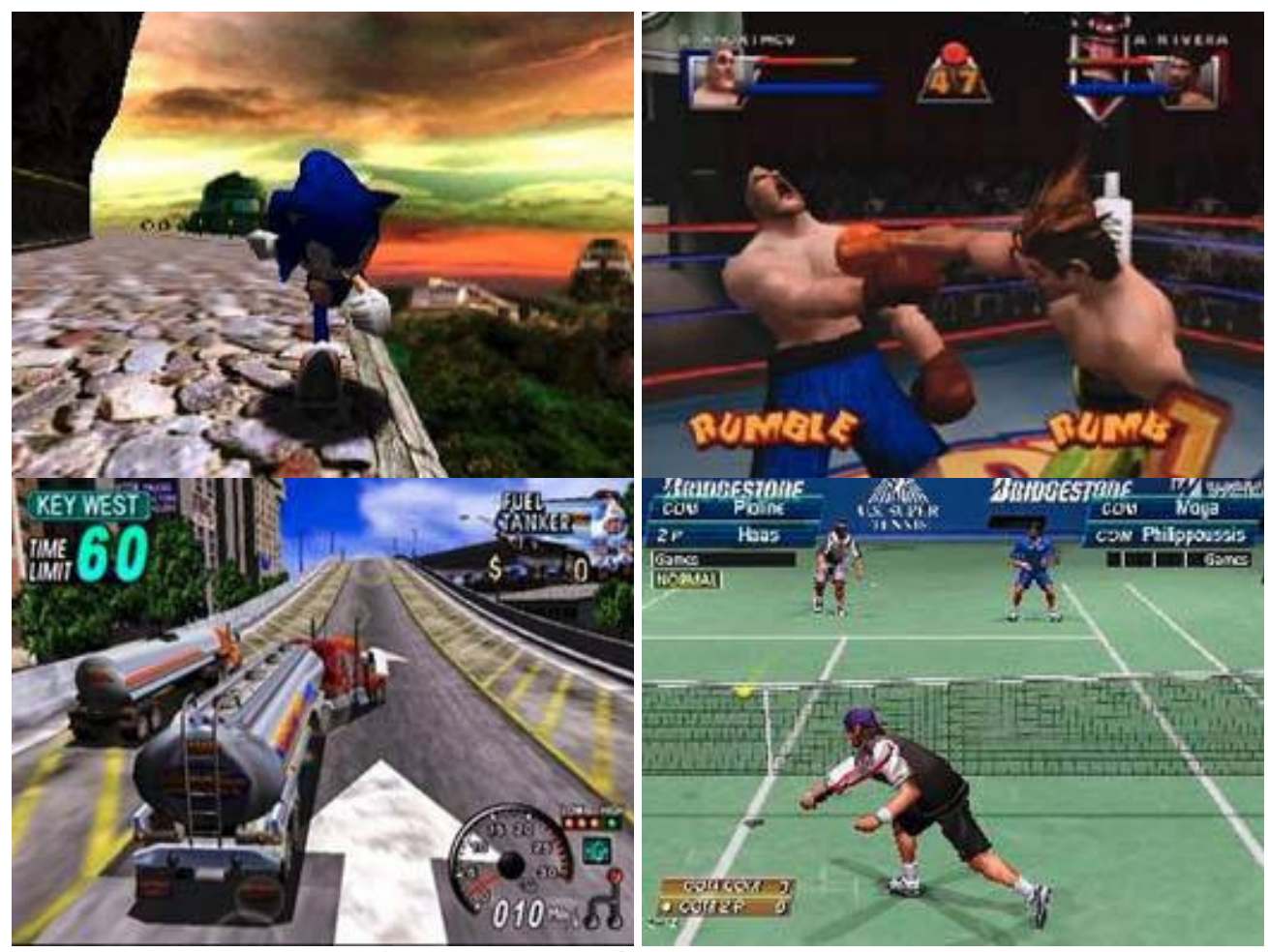

Ilustração 36 - Os excelentes gráficos tridimensionais do Dreamcast

Fonte: http://outerspace.ig.com.br/retrospace/ (Acesso em: 29 dez.2008)

Em 2000 a Sony lançou o Playstation 2 (comercializado até hoje), que sucede o primeiro console da companhia em tecnologia, qualidades gráficas e também em vendas. Além do desempenho de processamento, o Playstation 2 conta com um 
modem periférico para acessar a internet e a uma loja virtual exclusiva de jogos online, além de promover a jogabilidade em rede. Utiliza canhão leitor de DVD para rodar jogos e passar filmes, integrando o filme e o jogo. A mídia em DVD dos jogos, tão popular e gravável como os CDs, promovem a cópia ilegal e pirata dos títulos e impulsionam a venda do console que já ultrapassa das 100 milhões de unidades. Com a abertura no desenvolvimento dos jogos, várias franquias se destacam por produções adultas com cenas de violência e sexo, abrindo a discussão sobre a censura e as más influências dos games.

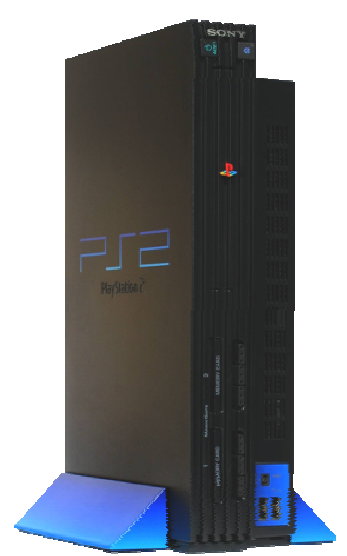

Ilustração 37 - O Playstation 2 da Sony

Fonte: http://pt.wikipedia.org/wiki/PlayStation_2 (Acesso em: 29 dez.2008)
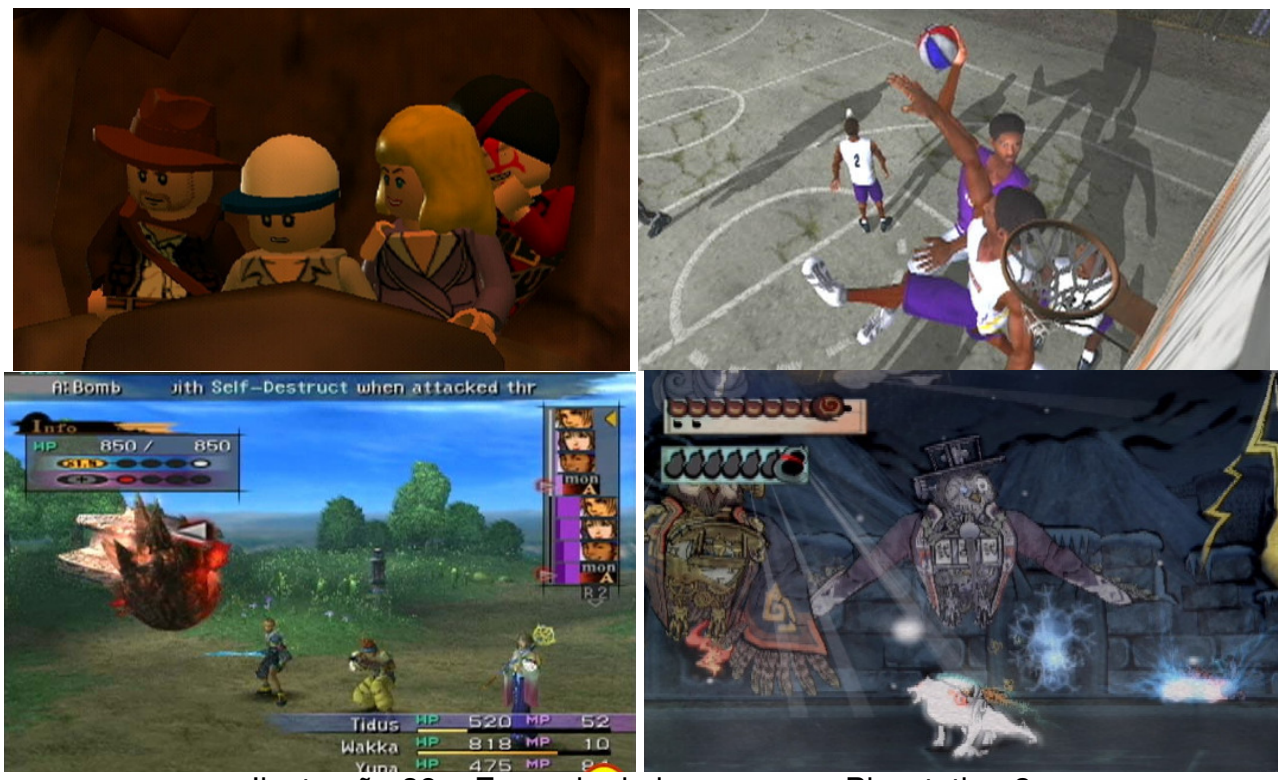

llustração 38 - Exemplo de jogos para o Playstation 2

Fonte: http://www.gamespot.com/ps2/ (Acesso em: 29 dez.2008)

O console suporta duas entradas USB (iguais aos computadores) e permite, portanto, o desenvolvimento de inúmeros periféricos como microfones, guitarras, 
mouses, etc. O destaque está no periférico EyeToy que consiste em uma câmera de vídeo que, além de capturar as imagens do jogador, também captura o movimento do seu rastro de calor (infravermelho) e permite a interação de objetos virtuais do jogo com o corpo e movimento do usuário. As possibilidades lúdicas da interação entre o corpo humano e estâncias virtuais são exploradas nos jogos e vão para instalações artísticas e outras formas de experimentação da integração homemmáquina.

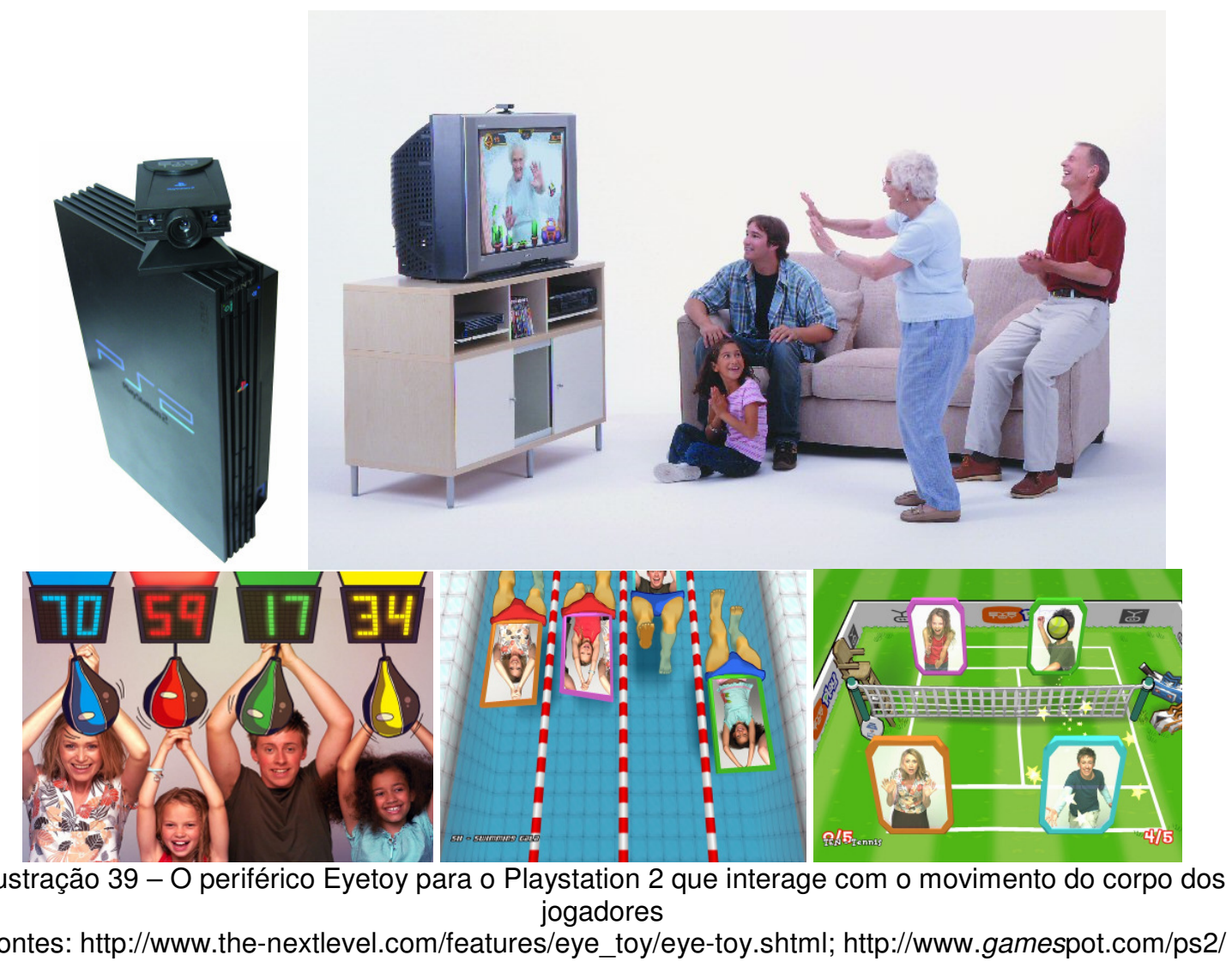

Fontes: http://www.the-nextlevel.com/features/eye_toy/eye-toy.shtml; http://www.gamespot.com/ps2/ (Acesso em: 29 dez.2008)

Em 2001, a Nintendo lançou o Game Cube com uso de uma mídia especial, o mini-DVD, com 1,5 GB de capacidade, contra os 4,7 GB do DVD comum. Além disso, a Nintendo carrega uma imagem institucional de empresa familiar, não apoiando jogos violentos e com temas adultos. Disso resulta a falta de investimento das softhouses em desenvolver títulos para o console. Não chegou a ser um fracasso de vendas, mas ficou bem atrás dos principais concorrentes. Nesse mesmo ano, a Microsoft se lançou no mercado dos videogames com o XBox, com ótimas capacidades gráficas e, como o Playstation 2 da Sony, utilizando o DVD como 
plataforma dos jogos para se popularizar em pouco tempo e alcançar a viceliderança do mercado.

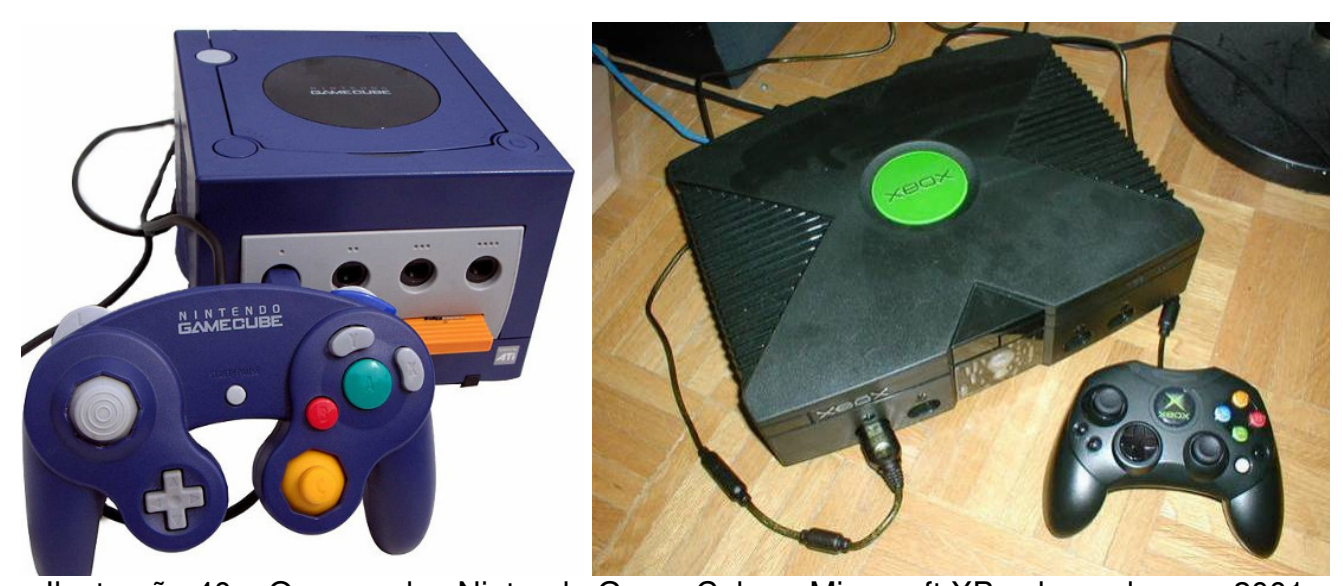

Ilustração 40 - Os consoles Nintendo Game Cube e Microsoft XBox lançados em 2001 Fontes: http://pt.wikipedia.org/wiki/Nintendo_GameCube; http://pt.wikipedia.org/wiki/Xbox (Acesso em: 29 dez.2008)

$\mathrm{Na}$ categoria dos portáteis, os celulares começaram a dar suporte a jogos simples e casuais, mas a Nintendo se manteve imbatível no ramo e consolidou o sucesso do Game Boy com uma versão superior do console, o Game Boy Advanced, lançado também em 2001. O portátil, além de compatível com os Game Boys anteriores, podia se conectar aos outros consoles da Nintendo integrando jogos da mesma franquia. O console suportava uma renderização poligonal de objetos e cenários levando os gráficos tridimensionais para os portáteis e, através de uma antena opcional, se conectava à internet por tecnologia wireless.

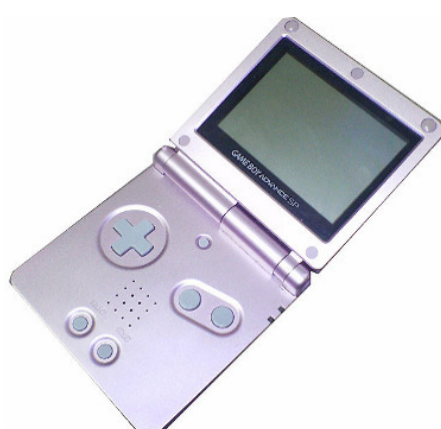

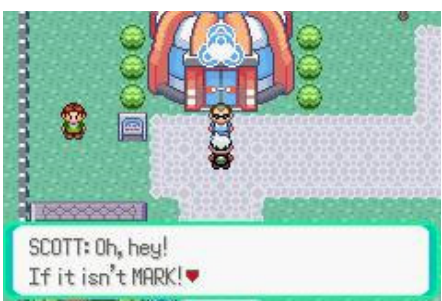

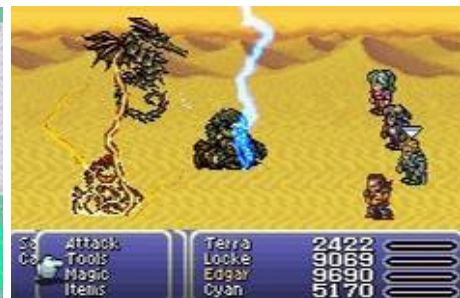

portátil Game Boy Advanced da Nintendo e exemplo de jogos

Fontes: http://pt.wikipedia.org/wiki/Game_Boy_Advance;

http://www.gamefaqs.com/portable/gbadvance/ (Acesso em: 29 dez.2008)

Vale lembrar que nenhum desses consoles foi oficialmente lançado no Brasil, mas a situação econômica favorável (crescimento da classe média) e a entrada definitiva do país na era digital proporcionou um alto consumo no mercado de games 
por importação. No caso do Playstation2 e do XBox, ambos com jogos baseados em DVD, com o destravamento por chip (um chip que quebra o bloqueio a DVDs não originais) o sucesso é muito grande pois os gamers encontram os preços baixíssimos de cópias não autorizadas dos jogos e até os títulos para baixar na internet.

\subsection{7 - Sétima geração dos games: novos apontamentos}

A concorrência da sétima geração dos videogames ocorreu em paralelo a uma outra batalha tecnológica: a evolução do DVD, ou seja, a nova plataforma de vídeos para high definition. A disputa foi entre o HD-DVD (patrocinado inicialmente por empresas como a Toshiba, Sanyo, RCA, Microsoft e Intel) e o Blu-Ray (desenvolvido e apoiado pela Sony, Philips,TDK, Sun Microsystens, Dell, Pioneer e Apple). O HD-DVD apresentava um disco com capacidade para $25 \mathrm{~GB}$ em camada simples e tinha uma produção mais barata, enquanto o Blu-Ray era mais cara para se produzir, mas tinha $50 \mathrm{~GB}$ em camada dupla. Hoje o HD-DVD está sendo abandonado, mas a disputa pela tecnologia da nova mídia colocou a Microsoft em confronto com a Sony e tal disputa também atingiu seus novos consoles.

No final de 2005, a Microsoft lançou o Xbox 360 sob plataforma do HD-DVD e processamento por três núcleos interdependentes. A capacidade gráfica de cálculo de polígonos teve um salto gigantesco permitindo que os jogos contenham ambientes e objetos tridimensionais muito detalhados se aproximando do cinema de animação 3D. Além dos gráficos, o processamento evoluiu para cálculos físicos e inteligência artificial. Dessa forma, a evolução do console acompanha e até exige um desenvolvimento tecnológico não existente comercialmente. Tendo conexão à internet nativa via wireless e entrada ethernet para jogos multiplayer em rede, 0 Xbox 360 foi lançado em diversas versões diferenciadas pela memória interna e periféricos, como saídas para vídeo de alta definição (HDMI), entre outros. Sobre o uso do HD-DVD que está sendo abandonado, a Microsoft já planeja lançar um modelo que utilize Blu-Ray, apesar do sucesso do console por conta do seu destravamento e das cópias ilegais dos títulos nessa mídia de produção mais barata. 


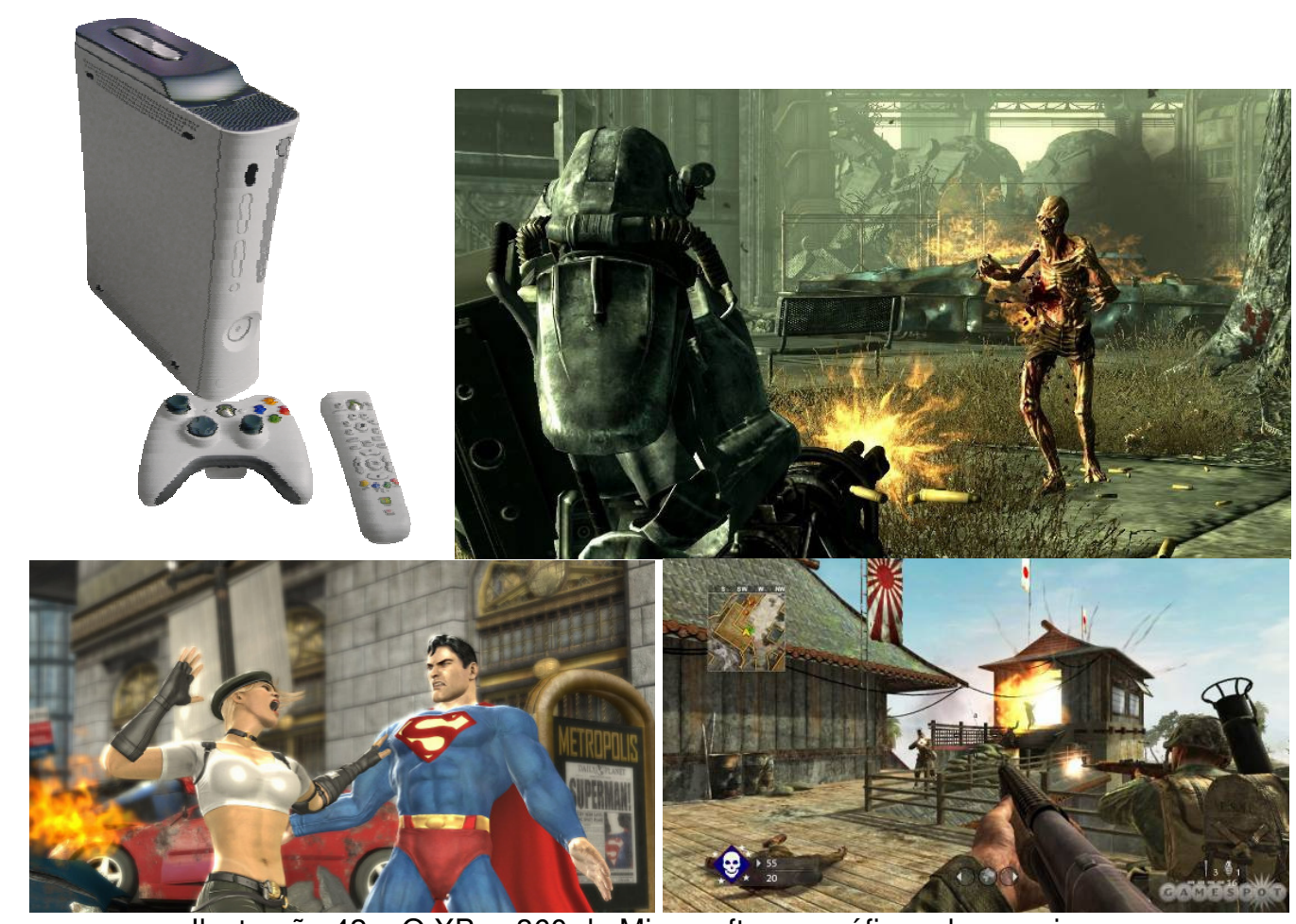

Fontes: http://pt.wikipedia.org/wiki/Xbox_360; http://www.gamefaqs.com/console/xbox360/ (Acesso em: 29 dez.2008)

A Sony lançou o Playstation 3 no final de 2006 com evoluções impressionantes que superam o processamento de qualquer computador doméstico. Seu controle também apresenta inovações de jogabilidade pois captura movimentos em seis eixos de rotação e translação para uma nova forma de interatividade além dos botões tradicionais. O console conta com saídas de áudio e vídeo digitais de alta definição. Com conexão à internet e HD interno de alta capacidade, o usuário pode comprar e baixar jogos diretamente no site Playstation Store (http://www.us.playstation.com/PSN/Store) além de ter suporte para jogos em rede. A Sony também disponibilizou uma plataforma de relacionamento social chamado Home, onde cada usuário pode criar um avatar para interagir com outros usuários, como uma espécie de "Second Life" com gráficos e possibilidades de animação extendidas. O sistema montado em Blu-Ray não pôde ser quebrado e ainda não há forma de copiar ilegalmente os títulos. Essa ação anti-pirataria da Sony garantiu altos investimentos e acordos com as softhouses, apesar de vender menos unidades do console em países como o Brasil onde o alto custo dos jogos tornam o Playstation 3 menos atraente. 


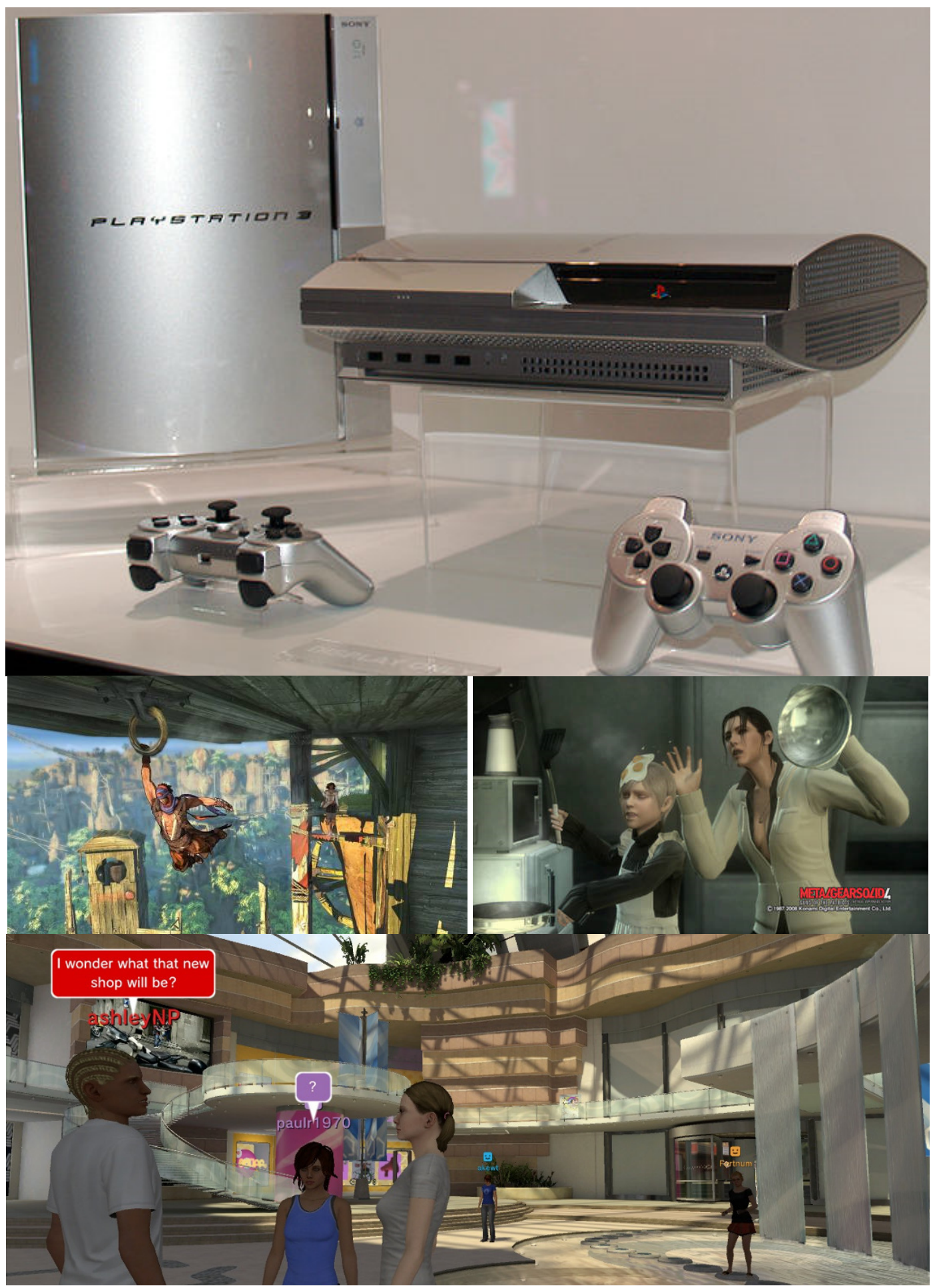

llustração 43 - O Playstation 3 da Sony, alguns de seus jogos e a plataforma de interação social Home, disponibilizada para os usuários

Fontes: http://pt.wikipedia.org/wiki/Playstation_3; http://www.gamefaqs.com/console/ps3/ (Acesso em: 29 dez.2008)

Mas, em termos de jogabilidade, a grande inovação está no Nintendo Wii que, depois de duas gerações de games sem protagonizar esse mercado, coloca a 
empresa novamente em destaque. A tecnologia do Nintendo Wii é inferior aos demais consoles, mas a concepção de usar os movimentos dos braços para interagir com o jogo tornou o console em sucesso de vendas. Ao invés de usar os dedos para rebater uma bola de beisebol, o jogador usa o braço, assim como para jogar tênis, boliche e até lutar de espada (vários acessórios ampliam a sensação do movimento adaptando os controles em volantes de carros, raquetes, e espadas). Com um periférico chamado Wii Fit, o usuário usa o corpo inteiro para fazer ginástica e movimentar as pernas. Essa usabilidade tem sido aproveitada para inovar em jogos que encantam e contagiam pessoas de várias faixas etárias (incluindo terceira idade e enfermos em recuperação).
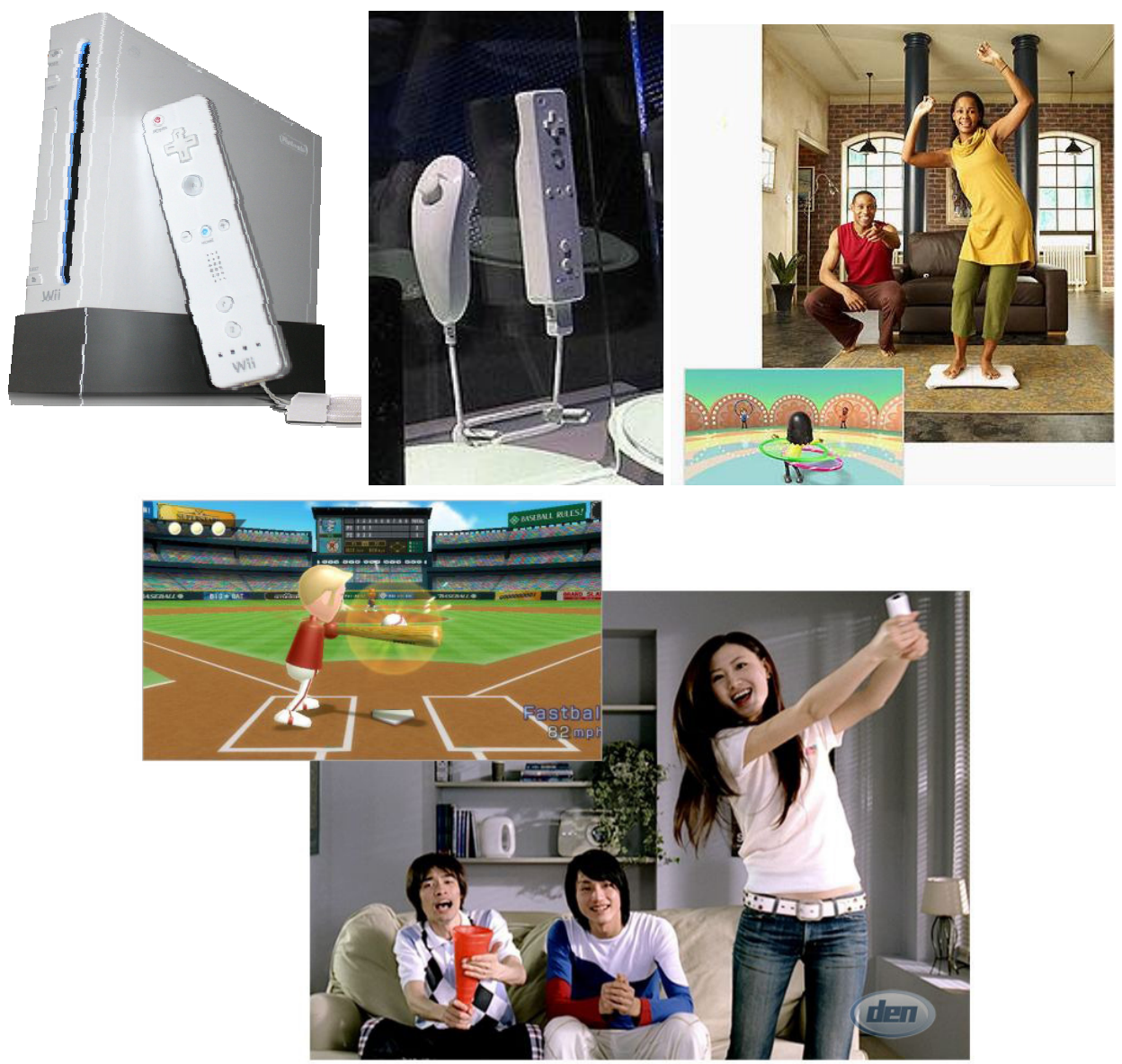

Ilustração 44 - O Nintendo Wii, o seu controle revolucionário que captura o movimento dos braços e o Wii Fit, para o movimento do corpo inteiro

Fontes: http://pt.wikipedia.org/wiki/Wii; http://nintendo-wii.tudosobre.info/nintendo-wii-finalmente-entrana-onda-saudavel-em-uma-academia/; http://lastshepard.wordpress.com.2008/05/12/wii-sports/

(Acesso em: 29 dez.2008) 

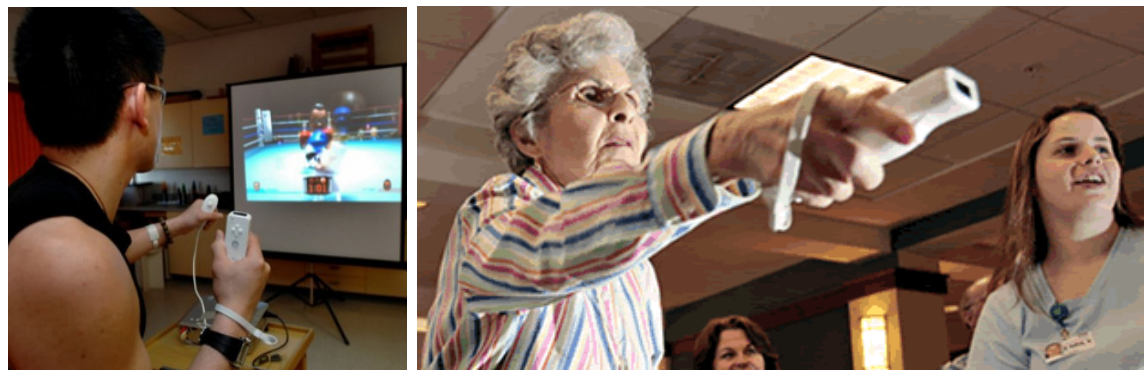

llustração 45 - Vitima de derrame cerebral em recuperação dos movimentos com auxílio do Wii e o uso do console para entreter usuários em uma casa de repouso nos EUA Fontes:

http://www.ubergizmo.com/15/archives/2007/10/nintendo_wii_helps_stroke_victims_recover.html; http://willyland.wordpress.com/category/wii/ (Acesso em: 29 dez.2008)
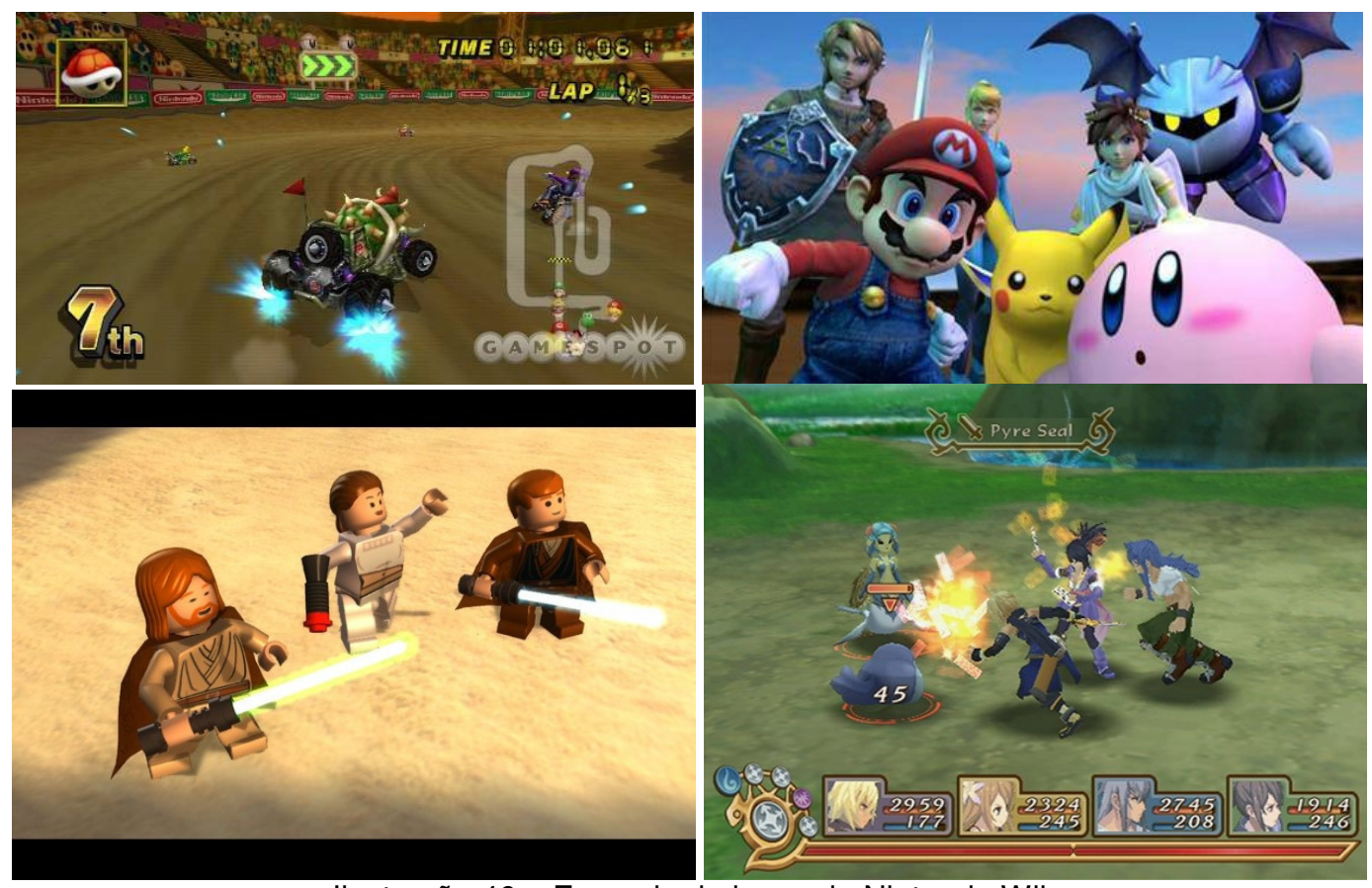

Ilustração 46 - Exemplo de jogos do Nintendo Wii

Fonte: http://www.gamefaqs.com/console/wii/ (Acesso em: 29 dez.2008)

Além da inovação tecnológica, o Nintendo Wii utiliza, diferente dos outros consoles da Nintendo que tinham mídias próprias, DVD comum para a plataforma dos games barateando o processo de produção dos títulos e permitindo, através de desbloqueamento de chip, que os usuários encontrem cópias ilegais para comprar em bancas piratas ou puxar na internet. Seu sucesso no mercado brasileiro, mesmo não havendo uma campanha de marketing enfática por parte da empresa representante, é notável.

No contexto dos portáteis, a Sony estreou com o seu potente PSP (PlayStation Portable) lançado em maio de 2005 e que contém qualidades gráficas similares ao Playstation 2 (com lógica tridimensional) em uma tela widescreen 
gigante (para os portáteis) de 4,3 polegadas, além de ser tocador de vídeos e música, ter rede wi-fi e softwares nativos como o Skype e ser extensível com periféricos como uma antena GPS e antena de TV digital. Os jogos lançados acompanham várias franquias presentes nos demais consoles da Sony e, em alguns casos, se integram a jogos do Playstation 3. Apesar de utilizar o disco próprio UMD com capacidade para 1,8 GB, para evitar cópias ilegais, o PSP tem entrada para cartões de memória Memory Stick Duo (os mesmo usados nas câmeras digitais da Sony) e um hackeamento no seu sistema operacional permite que jogos puxados na internet possam ser jogados via cartões. Com essa quebra, o PSP vem ganhando mercado considerável no Brasil.
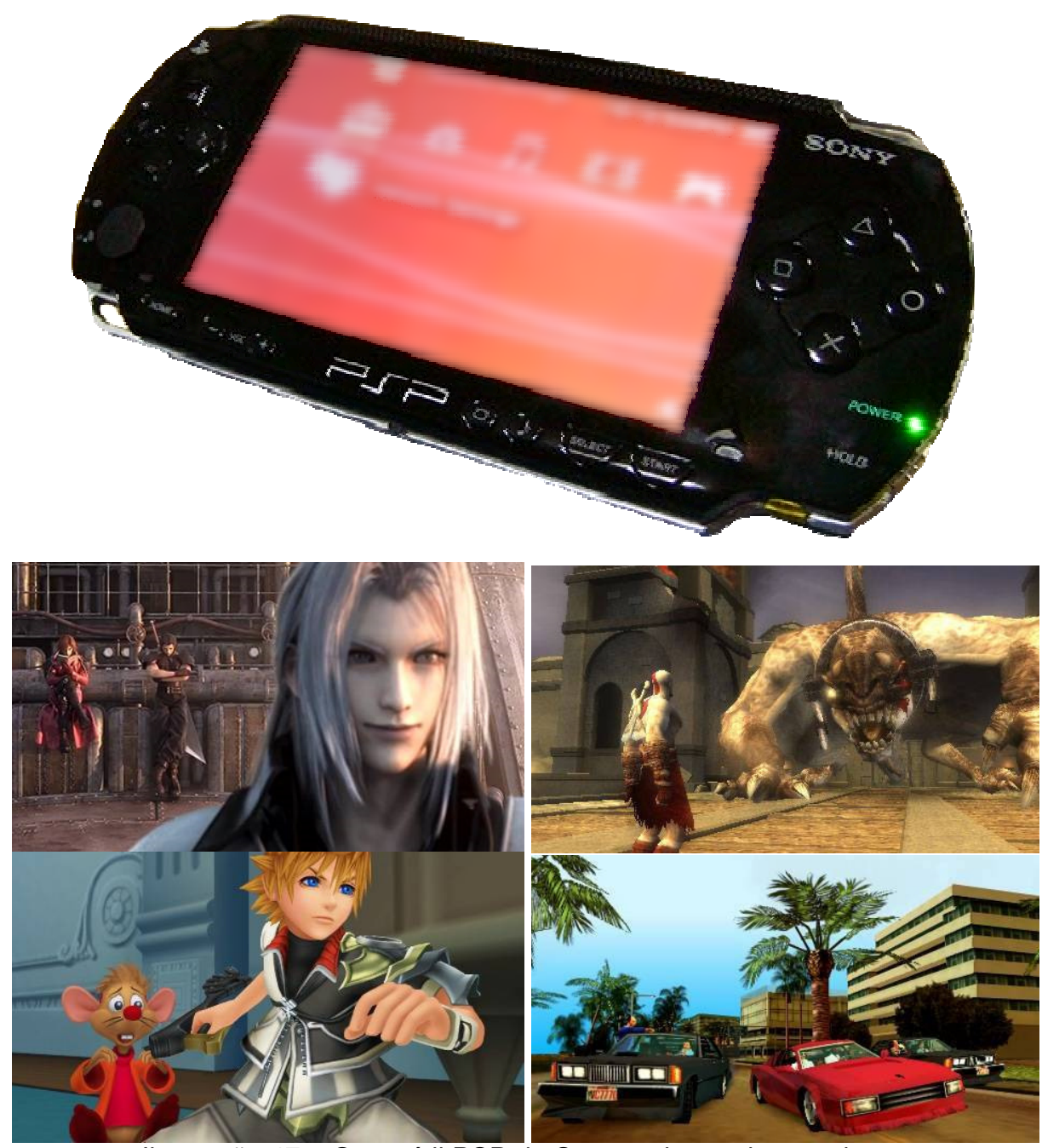

llustração 47 - O portátil PSP da Sony e alguns de seus jogos

Fontes: http://pt.wikipedia.org/wiki/PlayStation_Portable; http://www.gamefaqs.com/console/psp/ (Acesso em: 29 dez.2008) 
O novo portátil da Nintendo, o Nintendo DS, é mais uma peça de inovação de jogabilidade para os games. O console é constituído por duas telas das quais uma é sensível ao toque e permite interações diversas com os jogos através de uma caneta especial (como as utilizadas em PDAs) e por um microfone sensível à voz humana. Dessa forma as interações vão além dos botões e podem ocorrer com escrita, desenho e até comando de voz. Muitos jogos se aproveitam dessas formas de interação para estabelecer novos paradigmas de jogabilidade o que atrai muito os jogadores de várias faixas etárias. Para os jogos, o Nintendo DS utiliza um cartucho próprio e tem outra entrada para os cartuchos de Game Boy Advanced (para manter a compatibilidade), além de se integrar com o Nintendo Wii via wi-fi. Apesar disso, algumas empresas conseguiram desenvolver um cartucho especial onde se embute o micro cartão de memória Micro SD (iguais aos utilizados em aparelhos celulares), onde pode se colocar jogos baixados na internet. Essa prática ilegal também promove as vendas do console.

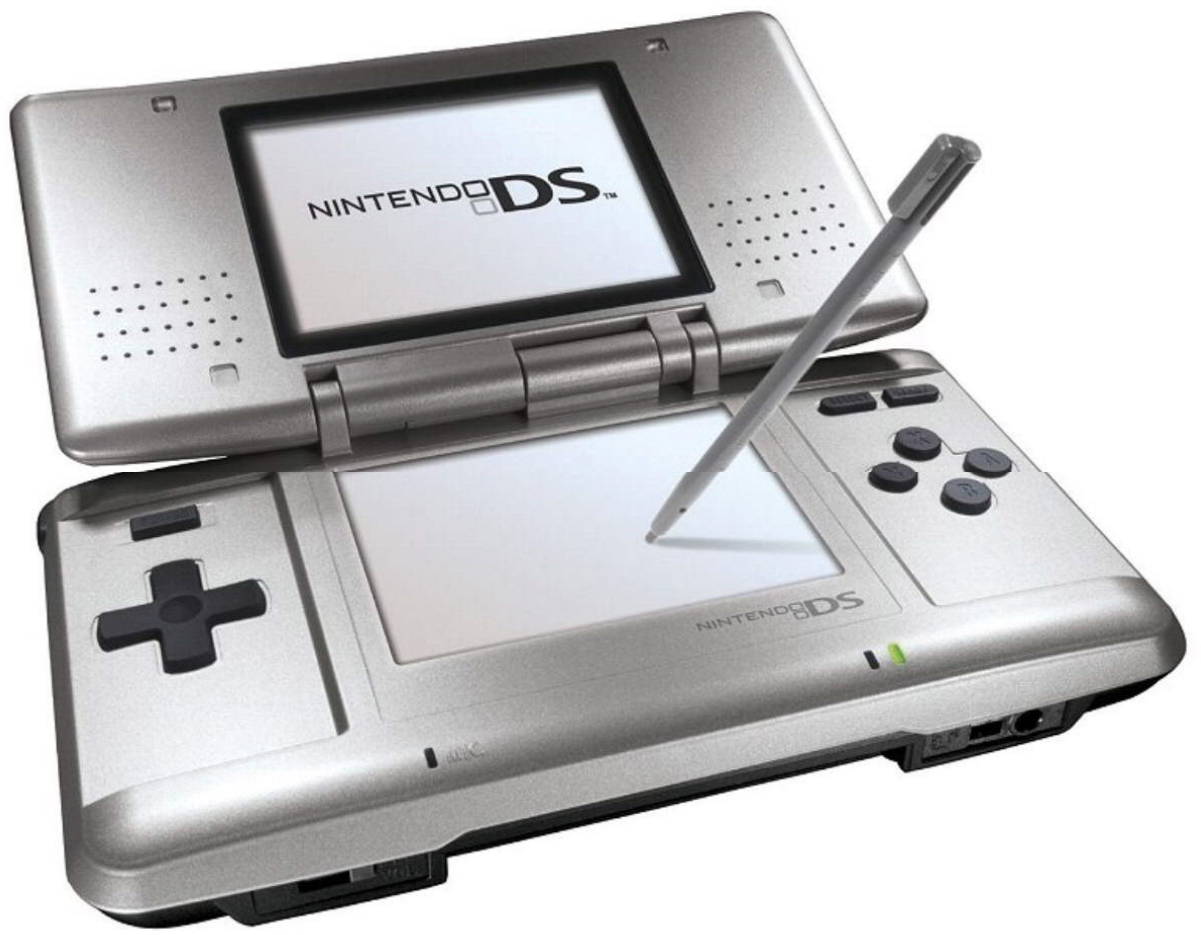

Ilustração 48 - O portátil Nintendo DS com inovadoras interfaces

Fonte: http://www.gameconsoles.com/images/Nintendo 20DS 20CONSOLE.jpg; (Acesso em: 29 dez.2008) 


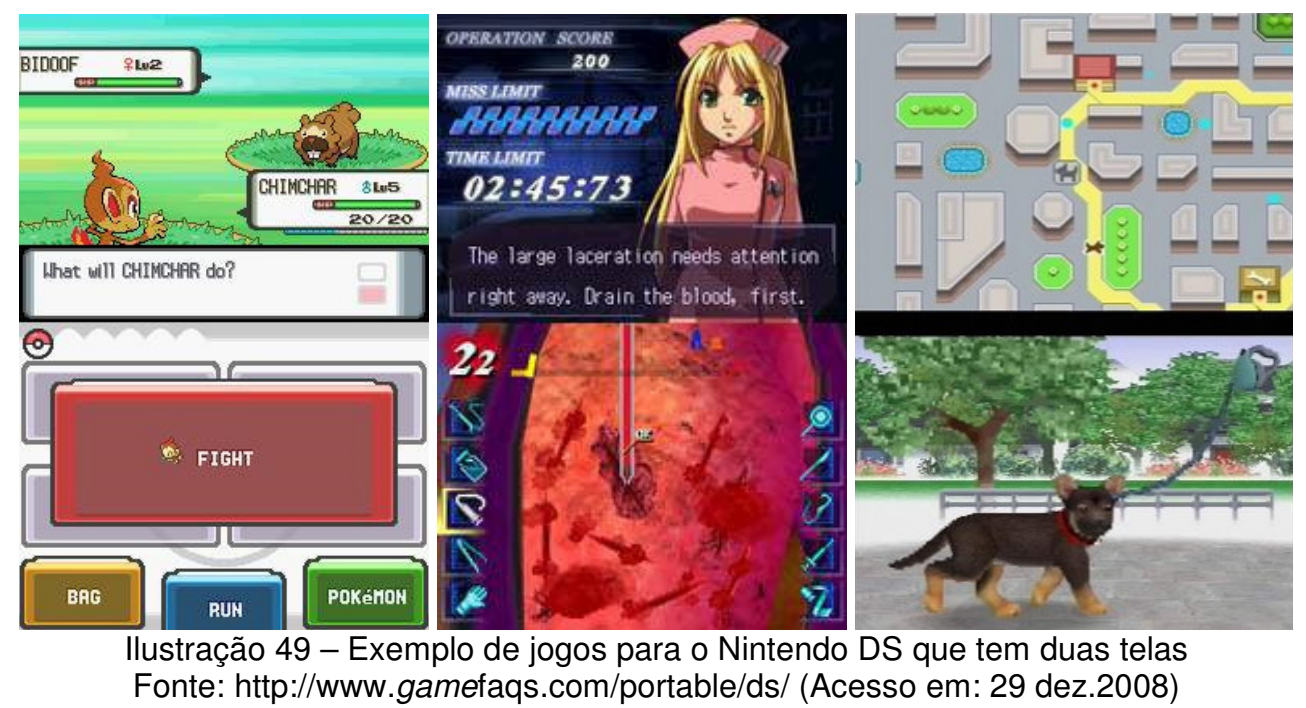

\subsection{8 - Considerações específicas sobre os jogos para computador}

Nunca houve uma diferenciação muito clara entre videogames e jogos específicos de computador, pois as inovações tecnológicas desenvolvidas para uma plataforma sempre migrou para a outra. Mas a interface de comando de teclado, mouse e microfone é um diferencial que sempre possibilitou interações próprias para os jogos de computador. Assim, apesar de atualmente as empresas desenvolvedoras de jogos tentarem construir franquias e títulos em multiplataforma para otimizar o lucro, algumas peculiaridades dos computadores resultam em jogos e jogabilidades específicos para a plataforma.

Em meados dos anos 60, vários programadores desenvolveram jogos onde o usuário deveria digitar números para o cálculo de combustível de uma nave espacial ou taxas de imposto para um fictício império mesopotâmico, por exemplo. Nesses casos, a computação matemática contava com uma interface totalmente textual, sem elementos gráficos.

O uso do teclado trouxe novas possibilidades de interface onde, por exemplo, o jogador tem vários comandos de controle através de teclas de atalho para jogos complexos de estratégia em que cada tecla alfa-numérica e combinações aciona uma ação. Nos videogames, limitados a alguns botões direcionais e de comando, essas a ações seriam impraticáveis e limitadas, mas apresentam, através dos joysticks, um controle mais ágil para jogos de lutas, por exemplo. Outra questão é a possibilidade de conversas, discussões e interações existentes em chats dos jogos em rede. Seja através do teclado ou através do uso de microfone e caixas de som, 
os usuários podem interagir comunicativamente entre si de forma que começa a acontecer só agora nos videogames.
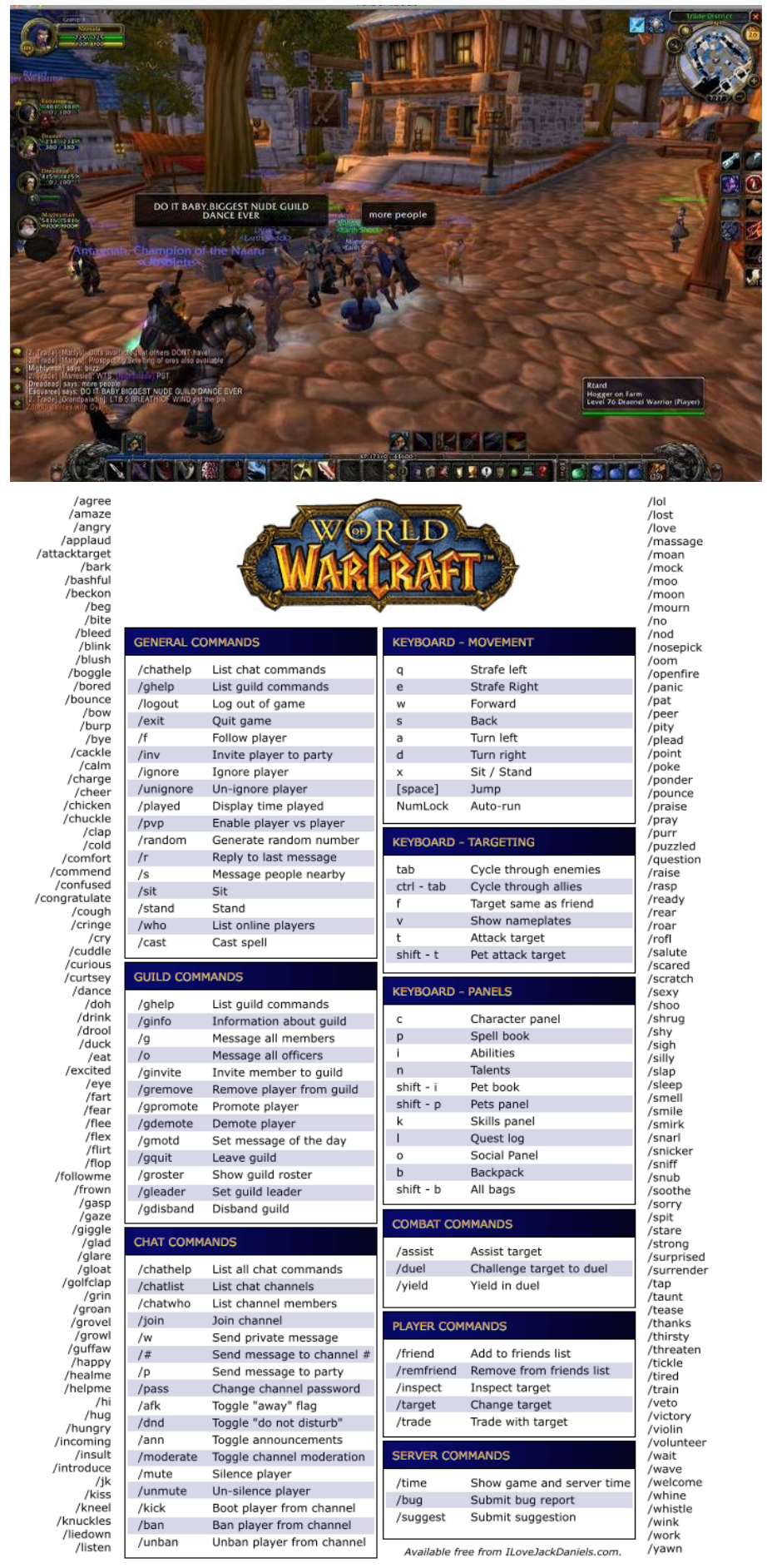

Ilustração 50 - O jogo para computador World of Warcraft, que conta com conversas por chat e lista de comandos por teclas de atalho

Fontes: http://ui24.gamefaqs.com/1399/gfs_5996_2_118.jpg;

http://www.flickr.com/photos/ilovejackdaniels/396262495/sizes/o/ (Acesso em: 02 jan.2009) 
Várias inovações de interfaces foram iniciadas nos anos 60 e 70 através da mente de Douglas Engelbart que almejava transformar o complicado computador em um componente tecnológico amigável para as pessoas. Sua contribuição vai das primeiras mediações tecnológicas em rede (e-mail e comunidades virtuais), uso da hipermídia, até a concepção de janelas de computador e desenvolvimento do mouse. E é exatamente através da estrutura gráfica em redes e do mouse que o computador adquiriu agilidades de interface extremamente amigáveis e velozes. Os jogos para computador utilizam, por exemplo, a velocidade de ação através do mouse para manipular objetos da cena para os jogos de quebra-cabeça que se valem de elementos dispersos na tela e que precisam ser conectados para resolver os desafios.

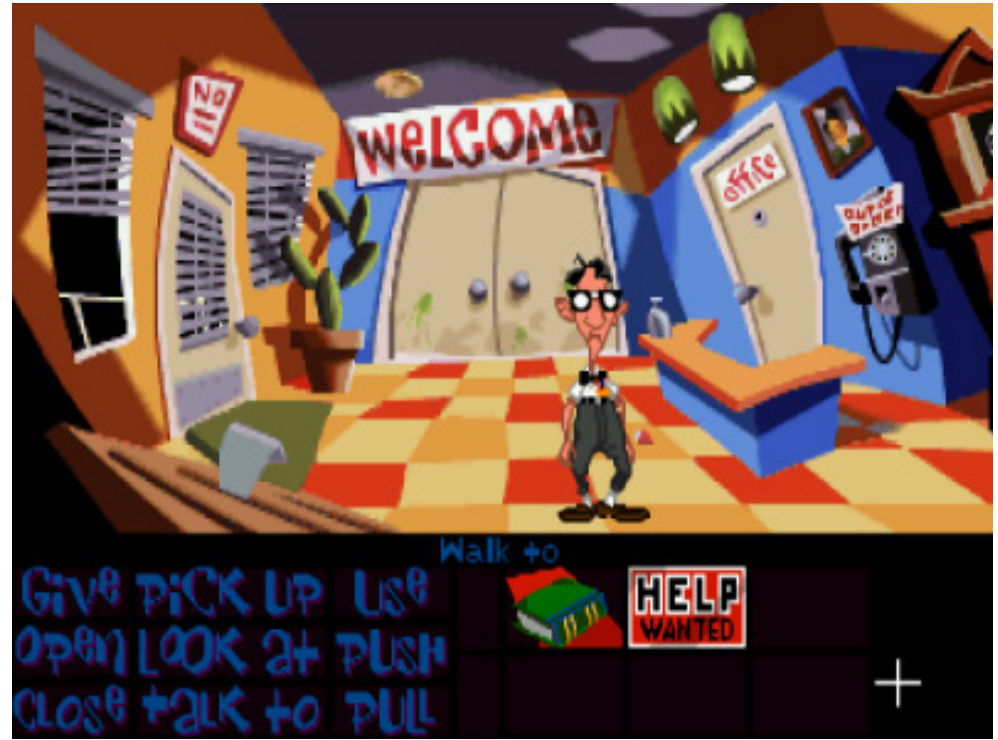

llustração 51 - O jogo para computador Day of the Tentacle, que conta com o mouse para resolver os desafios ao juntar comandos e objetos

Fonte: http://blog.computerwoche.de/wp-content/uploads/tentacle.png (Acesso em: 02 jan.2009)

De qualquer forma, os novos consoles de videogames e os novos computadores com configurações voltadas para os jogos apresentam características de potências de processamento muito similares e, de certa forma, buscam explorar diversas interfaces para promover a ludicidade digital integrada em rede.

Mas a maior interface lúdica estabelecida exclusivamente entre homem e computador ocorre através dos mods (da palavra inglês modification, ou modificação em português), ou seja, a possibilidade do jogador montar, baseando-se na engenharia de game já pré-construída, seus próprios cenários e personagens. Além da construção artística de modelos, cenários, elementos e animações, o jogador, 
através de comandos básicos em linguagem de alto nível (programação com comandos mais intuitivos), pode alterar a própria lógica dos jogos. Esse comportamento acaba por aproximar o jogador ao programador, tornando-o em produtor de conteúdo e de informação em intimidade com a tecnologia.
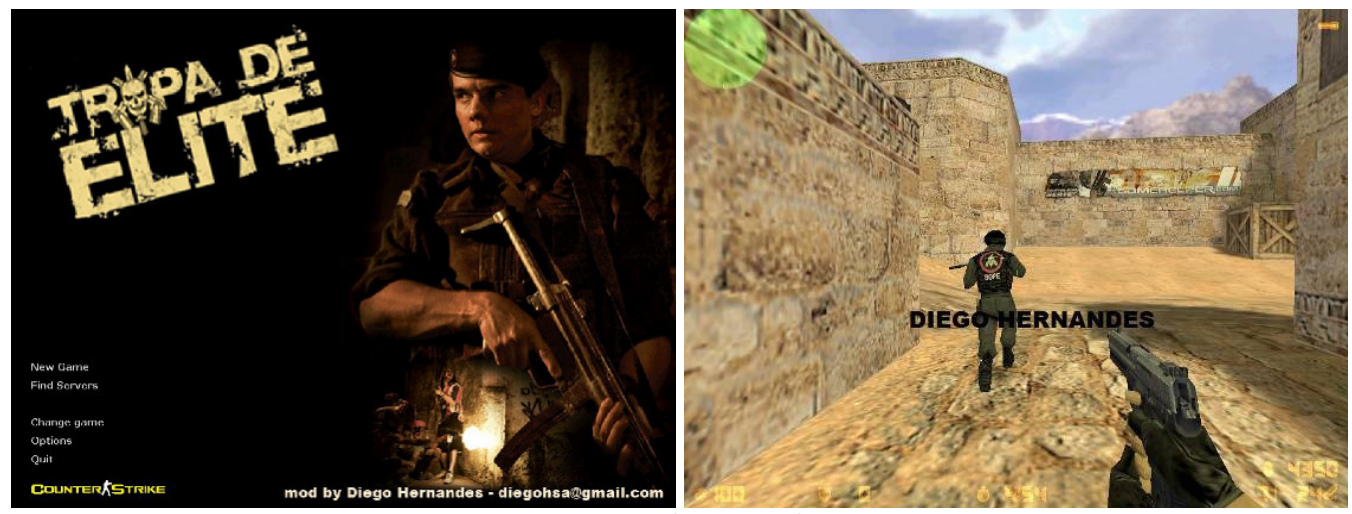

Ilustração 52 - Exemplo de mod do popular jogo Counter Strike, adaptando o popular filme Tropa de Elite para os games

Fonte: http://bopecs.blogspot.com/ (Acesso em: 02 jan.2009)

Uma forma de compreender a peculiaridade dos jogos de computador é analisar as vendas por tipo de jogos. No caso, o relatório "Essential Facts About The Computer And Video Game Industry"1 da ESA (Entertainment Software Association) mostra uma forte tendência de jogos de estratégia e de tiro (que se valem muito de teclas de atalho), mouse e comunicação por chat ao comparar os maiores sucessos de venda por gênero de jogos dos consoles e dos computadores.

3EST-SELLING VIDEO GAME SUPER GENRES BY UNITS SOLD, 2007

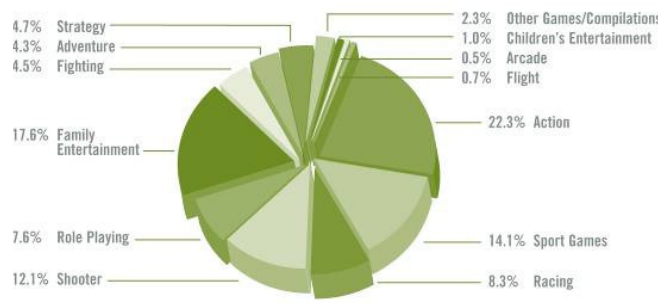

BEST-SELLING COMPUTER GAME SUPER GENRES BY UNITS SOLD, 200\%

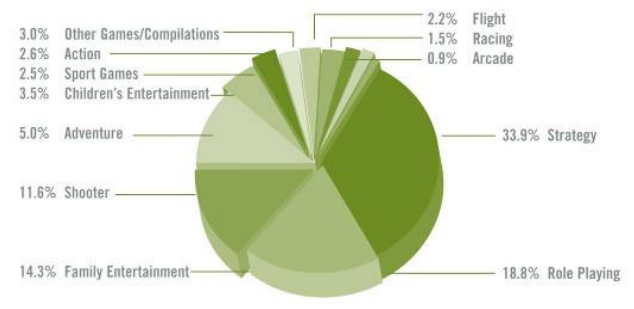

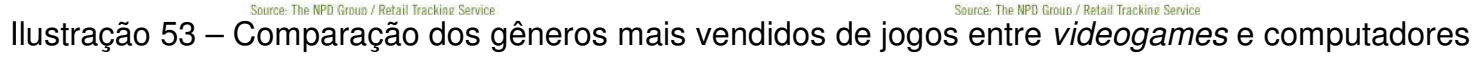
Fonte: ENTERTAINMENT SOFTWARE ASSOCIATION. Essential Facts About The Computer And Video Game Industry. 2008

\footnotetext{
${ }^{1}$ ENTERTAINMENT SOFTWARE ASSOCIATION. Essential Facts About The Computer And Video Game Industry. 2008
} 


\subsection{9 - Algumas tendências para as próximas gerações dos videogames}

Não existe consenso sobre o próximo passo tecnológico em torno dos games. Existe uma tendência clara de aprimoramento gráfico, cálculo de física real e implementação de inteligência artificial cada vez mais elaborada para estabelecer uma compreensão de interação entre jogador e jogo cada vez mais reais. Além disso, existe uma clara vertente de ações em rede através de jogos multiplayer, ou seja vários jogadores, intermediados pelos computadores e consoles, batalhando entre si ou se unindo para vencer desafios.

Mas em termos de novos paradigmas de jogabilidade, algumas tendências começam a entrar em foco, estabelecendo novas interfaces de iteração entre o homem e máquina. Uma primeira vertente ocorre em relação à interface visual que, acompanhando a evolução de resolução, contraste e brilho, desenvolve uma outra abordagem de ambientação em três dimensões e que segue a imersão em realidade virtual.

Uma abordagem que vem sendo aprimorada há tempos é o desenvolvimento de óculos 3D que, oscilando imagens separadas para o olho esquerdo e olho direito, proporciona a sensação de profundidade. Muitos consoles já tentaram implementar essa tecnologia, mas só agora, a partir do Playstation, quando os consoles passaram a enfocar na lógica visual e estrutural tridimensional, existem boas condições de implementações, já que o recurso é cada vez mais empregado no cinema e, portanto, passa por um momento de popularização.

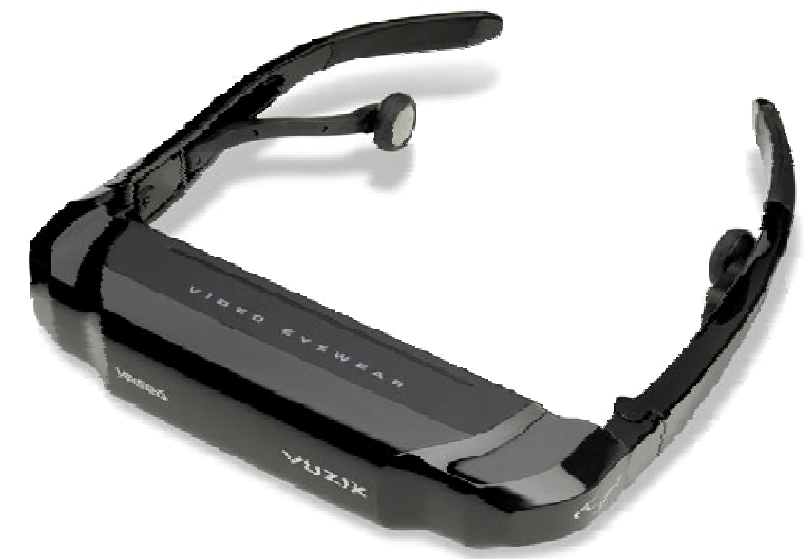

Ilustração 54 - O Vuzix - VR920 Head Mounted Display da E-Dimensional que integra imagens e áudio em três dimensões

Fonte: http://www.edimensional.com/ (Acesso em: 02 jan.2009) 


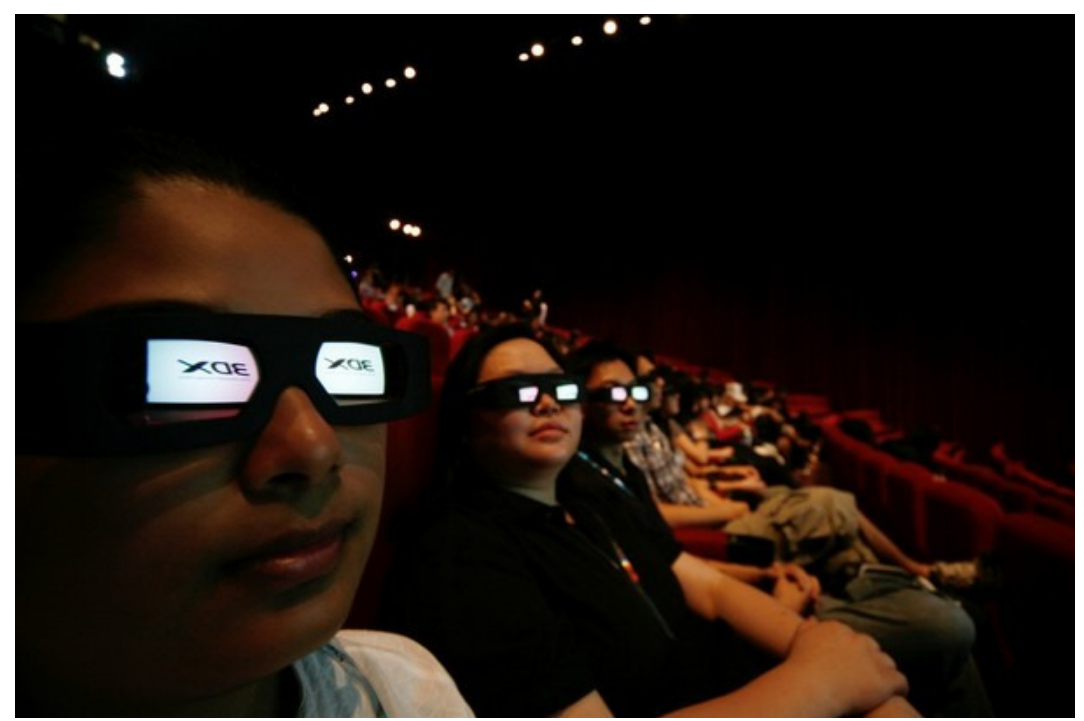

Ilustração 55 - A experiência em cinema 3D no 3DX Film Festival, em 18 de novembro de 2008, Singapura

Fonte: http://www.daylife.com/photo/04xe0WSbBN6XT (Acesso em: 02 jan.2009)

Outra linha de interface visual aborda o conceito de realidade aumentada, onde o usuário amplia a realidade através de telas e óculos, que imprimem elementos virtuais a partir de elementos materiais reconhecidos por uma câmera e softwares. Um exemplo já foi demonstrando para o Playstation 3 onde uma câmera captura os desenhos de um jogo de cartas e apresenta na tela monstros animados das mesmas cartas fazendo as ações pretendidas pela combinação das cartas.

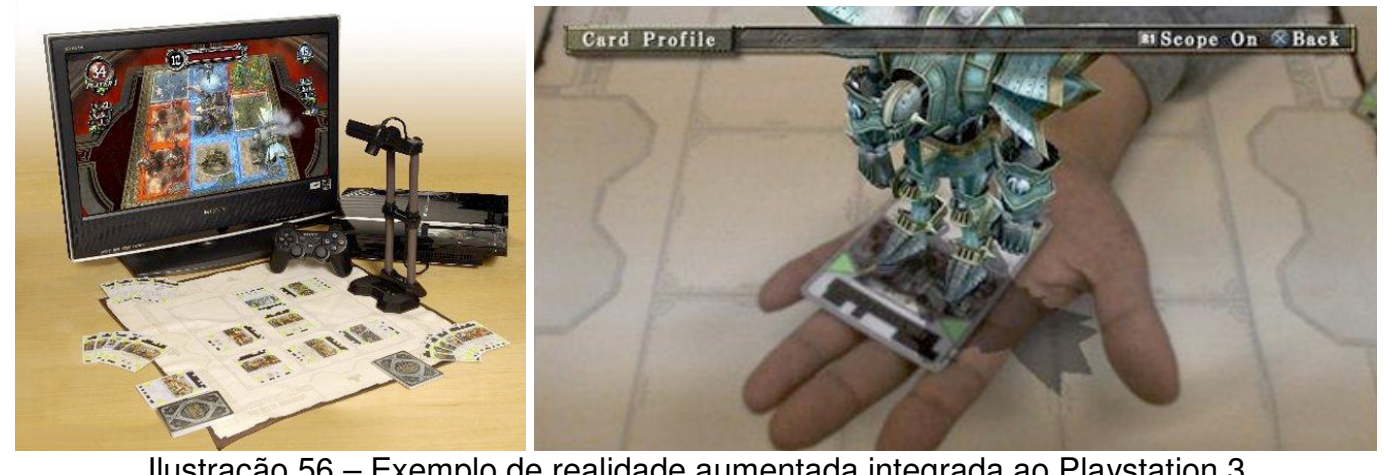

llustração 56 - Exemplo de realidade aumentada integrada ao Playstation 3

Fonte: http://kotaku.com/255419/ps3-hd-eye-toy-card-game-dated (Acesso em: 02 jan.2009)

A mais inovadora interface de comando prometida é o Emotiv, um tipo de capacete com eletrodos capazes de captar as ondas cerebrais e compreendê-las como comando lógico ao detectar aspectos afetivos (as emoções do usuário), cognitivos (os pensamentos conscientes do usuário) e expressivos (as expressões faciais do usuário). O dispositivo ainda não está disponibilizado, mas já é alvo de 
vários estudos de aplicação, sendo possível ser usado até para controlar cadeira de rodas. Mas o grande apelo está para o seu uso em games, inovando a forma de interagir e possibilitando jogar com "a força da mente"

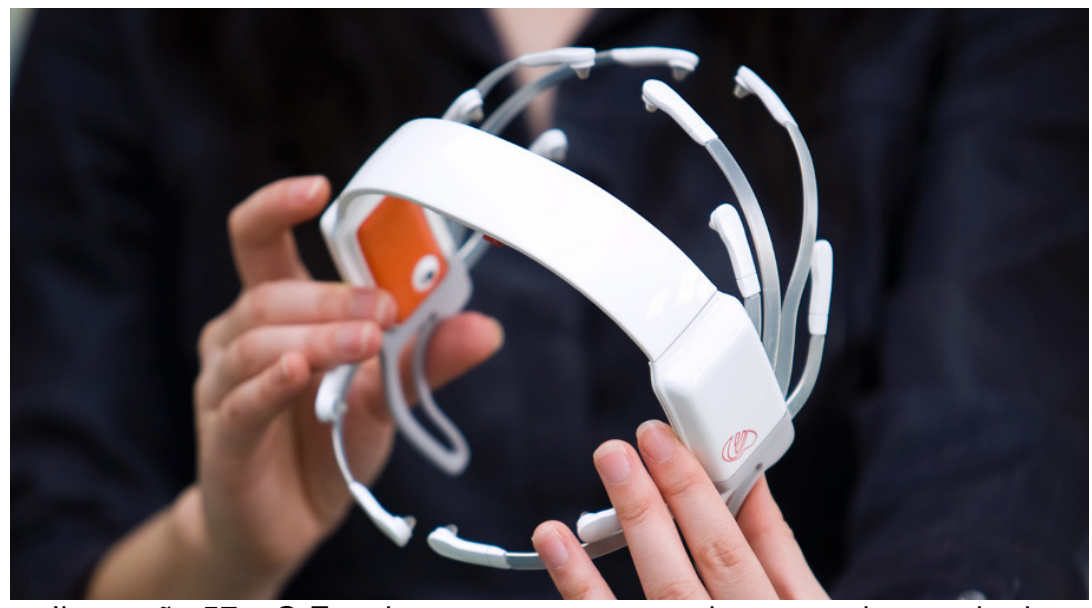

Ilustração 57 - O Emotiv que captura comandos por ondas cerebrais

Fonte: http://emotiv.com/ (Acesso em: 02 jan.2009)
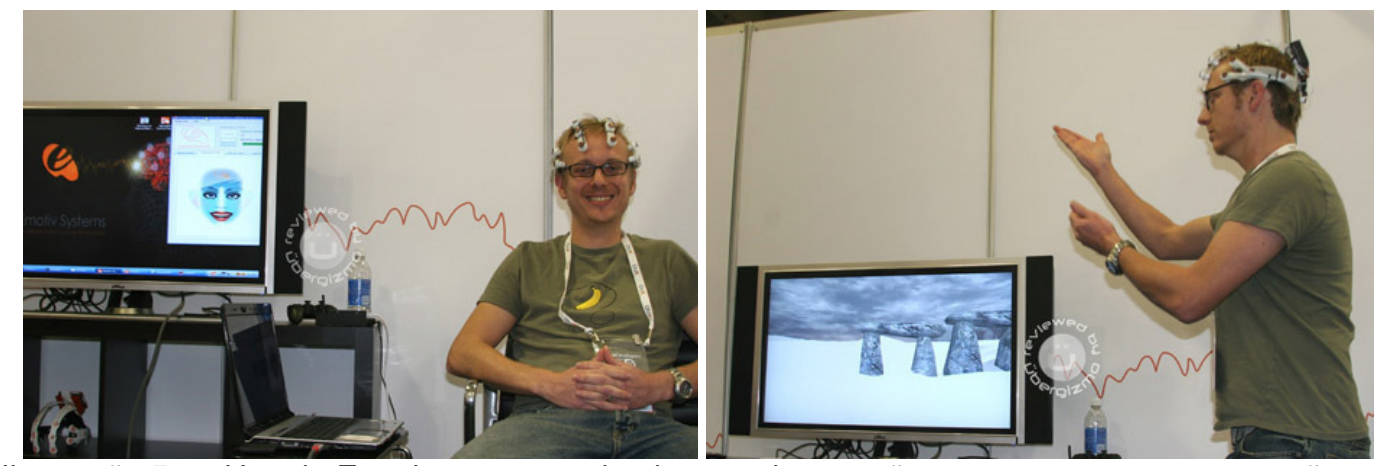

llustração 58 - Uso do Emotiv para reconhecimento de emoções, pensamentos e expressões do usuário em uma nova forma de interação com o computador

Fonte:http://www.ubergizmo.com/15/archives/2007/03/emotiv_the_brain_computer_interface_technolo gy.html (Acesso em: 02 jan.2009)

\section{2 - Aspectos econômicos (mercado e comportamento de consumo) dos games}

Além do panorama histórico dos videogames, para compreender a relação que existe entre o homem e a sociedade e o consumo de ludicidade eletrônica-digital, é necessário compreender os aspectos econômicos presentes no universo dos games, analisando o mercado e o comportamento de consumo. Infelizmente não existem dados específicos sobre o uso e consumo de jogos eletrônicos no Brasil. 
Para compensar essa falta de dados objetivos, a pesquisa conta com relatórios internacionais e norte-americanos que monitoram minuciosamente a indústria dos games, compreendendo seus rendimentos e potenciais, já que constituem um mercado muito significativo no contexto mundial, sobretudo na realidade norteamericana, onde se produz a maior parte dos exemplares comerciais.

\subsection{1 - O mercado mundial em ascensão dos games}

Segundo análises da ESA (Entertainment Software Association) ${ }^{2}$, o mercado de jogos para computadores e videogames dos EUA emprega mais de 80 mil funcionários diretos com uma média salarial de USS $\$ 92.300$ por ano. O consumo americano de computadores e videogames chegou em 2007 em 267,8 milhões de unidades, ou seja, 9 unidades a cada segundo. Isso demonstra um mercado extremamente forte para alimentar a procura por hardware computacional. Além da indústria dos games, existe um aquecimento de aproximadamente US\$ 6,1 bilhões em outras vendas relacionadas diretamente ao entretenimento eletrônico-digital. Por exemplo, aproximadamente US\$73 milhões em TVs com qualidade high definition (HDTV) foram vendidos por conta de suas compatibilidades com o XBox 360 da Microsoft.

O relatório "Global Entertainment and Media Outlook: 2008-2012" ${ }^{3}$ da empresa PricewaterhouseCoopers mostra vários aspectos e tendências da indústria dos videogames que envolvem os jogos de console, de computador, jogos online, jogos wireless (que utilizam a tecnologia de internet sem fio) e jogos de anúncios publicitários, desconsiderando os próprios aparelhos e componentes periféricos. $O$ mercado mundial dos games atingiu em 2007 um patamar em vendas na casa dos US\$ 41,9 bilhões e tem forte tendência de alta. Segundo a empresa de consultoria, em 2012, o mercado atingirá o patamar de US\$68,3 bilhões, em uma previsão de crescimento anual de $10,3 \%$ da indústria dos games, sobretudo por conta da nova geração de consoles, portáteis e jogos para dispositivos móveis. Como mostra o gráfico abaixo:

\footnotetext{
${ }^{2}$ ESA - ENTERTAINMENT SOFTWARE ASSOCIATION - http://theesa.com

3 PRICEWATERHOUSECOOPERS International Limited. Global Entertainment and Media Outlook: 2008-2012. 2008
} 


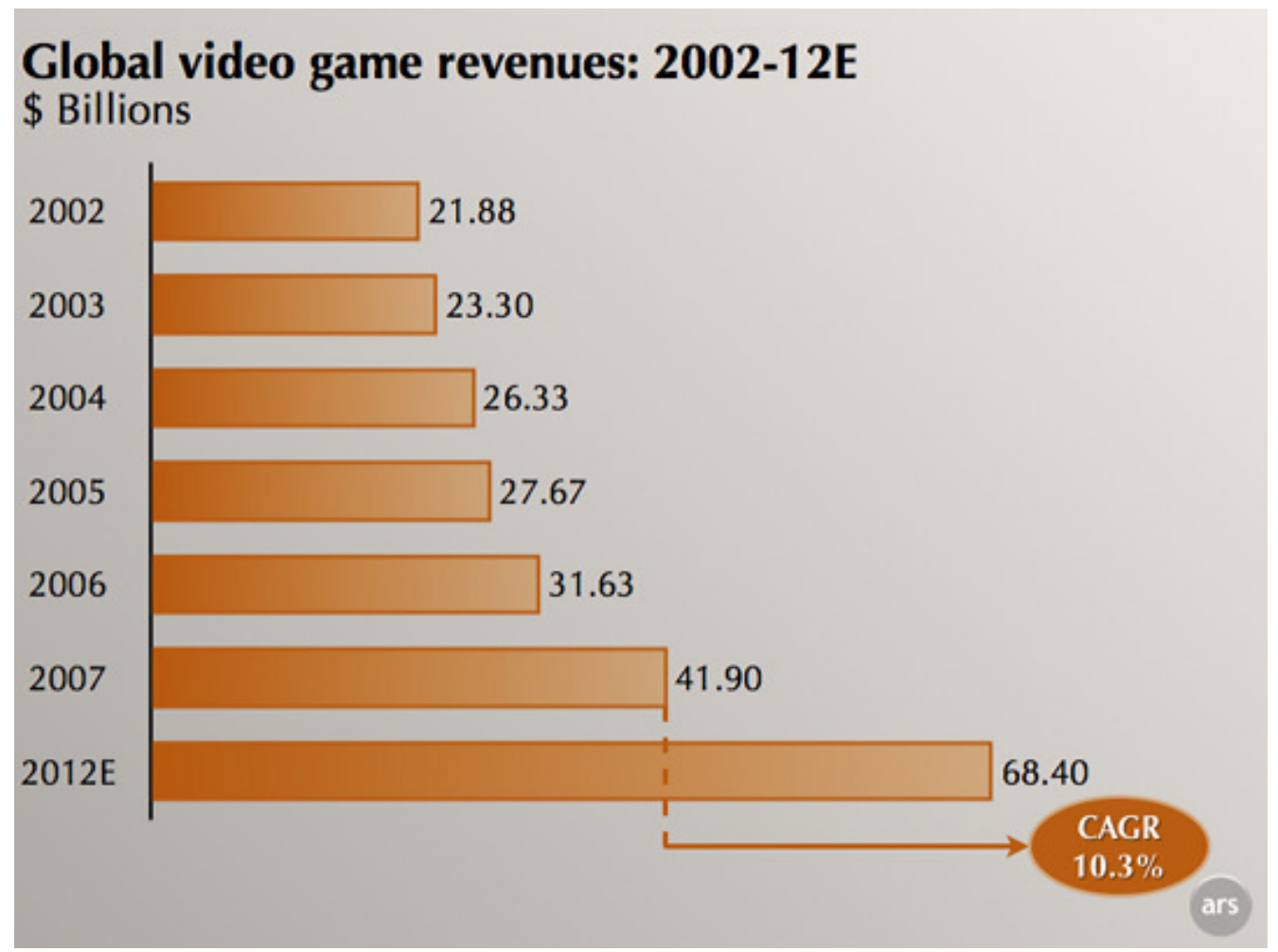

Ilustração 59 - Evolução mundial das vendas de jogos eletrônicos em bilhões de dólares Fonte: http://arstechnica.com/news.ars/post.20080618-gaming-expected-to-be-a-68-billion-businessby-2012.html (Acesso em: 02 jan.2009)

Essa taxa de crescimento é prevista para ocorrer segundo a seguinte distribuição para as diversas plataformas:

\begin{tabular}{|c|c|c|c|}
\hline Plataforma & $\begin{array}{c}\text { Vendas em 2007 } \\
\text { (US\$ Bilhões) }\end{array}$ & $\begin{array}{c}\text { Previsão para } \\
\mathbf{2 0 1 2} \\
\text { (US\$ Bilhões) }\end{array}$ & $\begin{array}{c}\text { Taxa de } \\
\text { crescimento }\end{array}$ \\
\hline Jogos para consoles & 24,9 & 34,7 & $39,36 \%$ \\
\hline Jogos online & 6,6 & 14,4 & $118,18 \%$ \\
\hline Jogos wireless (dispositivos móveis) & 5,6 & 13,5 & $141,07 \%$ \\
\hline Jogos para computador & 3,8 & 3,6 & $-5,26 \%$ \\
\hline Jogos de anúncios publicitários & 1 & 2,3 & $130,00 \%$ \\
\hline
\end{tabular}

llustração 60 - Tabela da evolução mundial das vendas de softwares de entretenimento Fonte: http://www.reuters.com/article/technologyNews/idUSN1840038320080618 (Acesso em: 02 jan.2009)

A nova geração de videogames impulsiona o mercado pelas inovações de processamento gráfico do XBox 360 e do Playstation 3 e pelas inovações interativas do Nintendo Wii. No final de 2007, só nos EUA, eram 9 milhões de unidades vendidas do console da Microsoft, lançado no final de 2005; 3 milhões do console da Sony e 7 milhões do console da Nintendo, ambos lançados no final de 2006. Além 
disso, conta-se com o bom desempenho de vendas do PSP e do Nintendo DS, portáteis da Sony e da Nintendo respectivamente.

O notável crescimento dos jogos online se dá pela capacidade de banda para o acesso à internet. Os cabos óticos e a tecnologia por satélite aumentam a capacidade de troca de dados e, portanto potencializam uma melhor jogabilidade em rede, promovendo o crescimento previsto de quase $120 \%$ em vendas dos jogos online, além da popularização dos massive multiplayer online games (jogos online para múltiplos jogadores). O crescimento de vendas de jogos para dispositivos móveis (jogos wireless) tem forte tendência de crescimento pelas melhorias de performances dos PDAs e celulares que suportam gráficos cada vez mais elaborados em telas cada vez maiores, além da tecnologia $3 G$ de transmissão para a compra dos games.

No entanto, se nota uma previsão de queda nas vendas de jogos para computador. As empresas estão deixando de investir no segmento por conta da pirataria que contamina todo o mercado temendo a diminuição de lucros por conta da facilidade de cópias. Contra isso, prefere-se investir nos jogos online, onde a cobrança mensal para o acesso aos servidores gera um maior controle de previsão dos lucros. Além disso, a estratégia é lançar títulos menos complexos e, portanto, mais baratos, que trabalhem como expansões e complementos.

A grande novidade é a perspectiva de crescimento sobre os jogos publicitários onde organizações encomendam games específicos sobre a temática que envolvem seus core business para promover seus produtos e sua imagem institucional. As negociações de compra e acordos entre a Microsoft e a Sony com a Massive e a IGA Worldwide, empresas especializadas em publicidade online com 0 emprego dos games.

Outra questão importante é a economia de trabalho movimentada pelo processo de produção. No mercado americano, o documento "Vídeo Games: Serious Business for America's Economy "A (ESA), aponta que, nos EUA, existem 144.000 empregados diretos na indústria de softwares de entretenimento, ganhando a média de US $\$ 67$ mil por ano, e que mais de US\$11,2 bilhões são movimentados na economia paralela (mercados, vendas online, brinquedos, pontos de venda, etc.) por influência direta dessa indústria. 


\subsection{2 - Comportamento do mercado consumidor de games}

Em um esforço para compreender o comportamento de consumo dos jogos, a ESA elaborou o relatório "Essential Facts About The Computer And Video Game Industry" ${ }^{5}$ que descreve a composição demográfica do mercado americano de consumo dos games. Mesmo sendo um panorama dos EUA, como ocorre em todo o contexto do consumo tecnológico digital globalizado, vários aspectos de comportamento ultrapassam as culturas nacionais e podem descrever um pouco do consumo mundial, incluindo o mercado brasileiro.

A pesquisa aponta que $65 \%$ dos americanos jogam títulos de computadores e/ou videogames, dos quais $60 \%$ é público masculino e que a idade média do jogador é de 35 anos. O perfil do comprador de jogos é de 40 anos de idade, sendo que a sua média de consumo de games dura aproximadamente 13 anos. Essas informações definem a estratégia das empresas no desenvolvimento dos seus produtos, subsidiando o processo de elaboração dos jogos segundo o entendimento do comportamento de consumo.
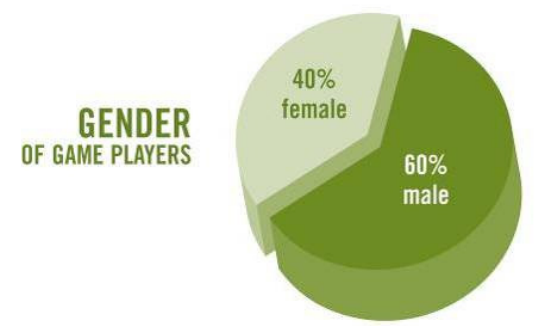

Ilustração 61 - Perfil do mercado consumidor dos games por gênero e idade

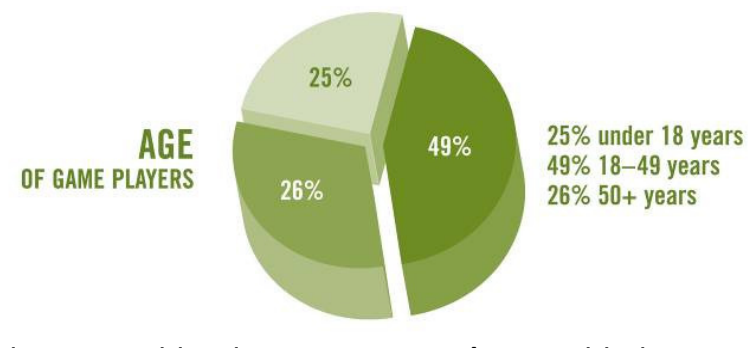

Fonte: ENTERTAINMENT SOFTWARE ASSOCIATION. Essential Facts About The Computer And Video Game Industry. 2008

Em termos de produto, os jogos mais visados são os que abarcam todas as idades, ou seja, os que têm um índice baixo de censura ao considerar o teor de violência e temas adultos. Isso significa que os jogos mais vendidos acabam enfocando temáticas adequadas para as crianças, tendo aprovação e apoio dos pais.

\footnotetext{
${ }^{4}$ ENTERTAINMENT SOFTWARE ASSOCIATION. Video Games: Serious Business for America's Economy. 2006

${ }^{5}$ ENTERTAINMENT SOFTWARE ASSOCIATION. Essential Facts About The Computer And Video Game Industry. 2008
} 


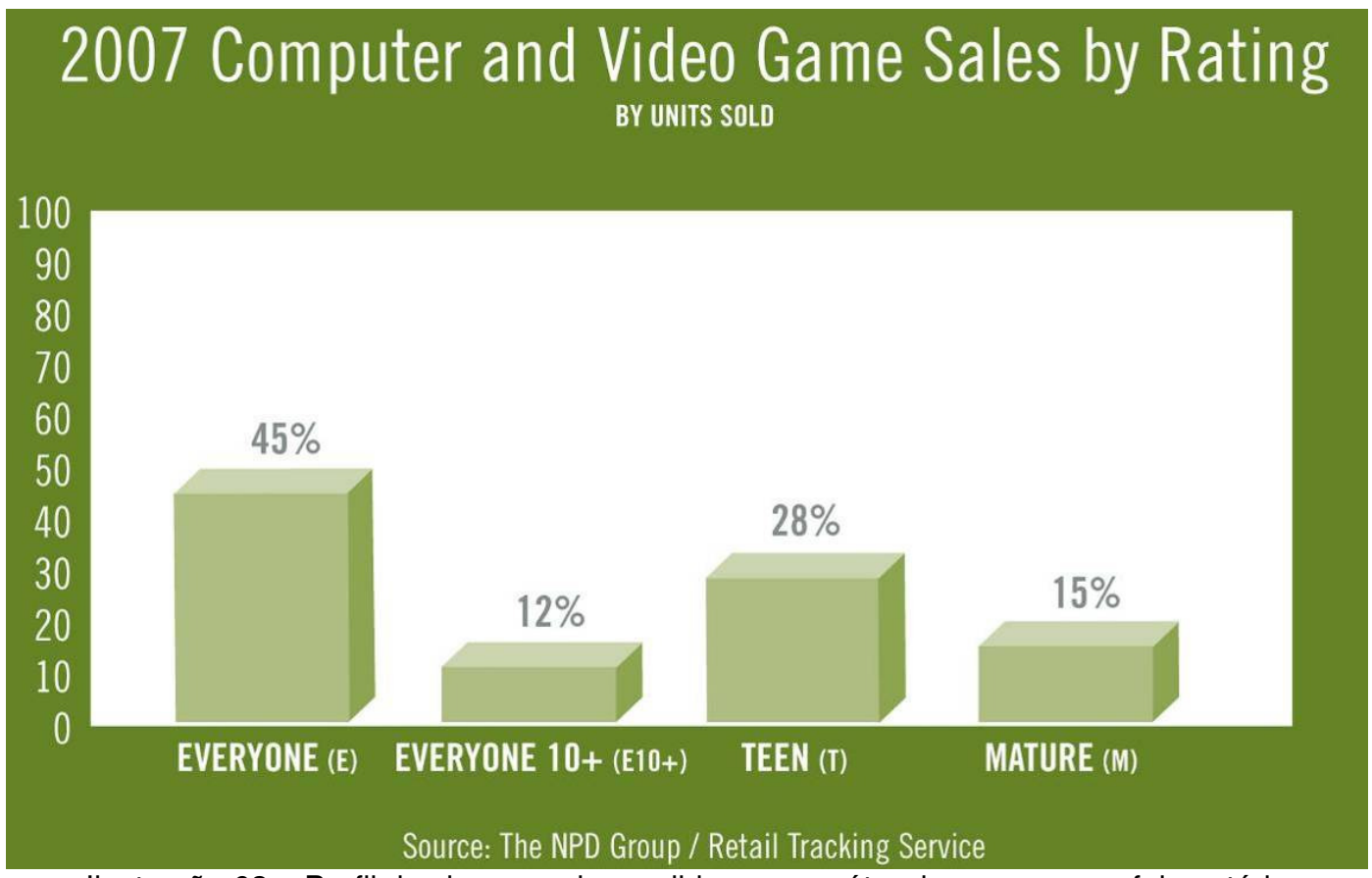

llustração 62 - Perfil dos jogos mais vendidos por caráter de censura por faixa etária

Fonte: ENTERTAINMENT SOFTWARE ASSOCIATION. Essential Facts About The Computer And Video Game Industry. 2008

O estudo mostra que:

- $94 \%$ das vezes os pais estão presentes na compra ou aluguel dos games;

- $63 \%$ dos pais acreditam que os games são positivos para a vida de seus filhos;

- $83 \%$ das vezes as crianças recebem permissão dos pais antes de comprarem ou alugarem games;

- Os pais relatam que monitoram os jogos que seus filhos jogam em $88 \%$ das vezes

As quatro principais razões que levam os pais a jogarem games com seus filhos são:

- É divertido para a família inteira (72\%);

- Porque eles são convidados (71\%);

- Porque é uma boa oportunidade de se socializarem com seus filhos $(66 \%)$;

- porque é uma boa oportunidade de monitorar o conteúdo do game $(50 \%)$ 
Existe também um estudo sobre do controle dos pais sobre o que seus filhos jogam. O resultado desse estudo é o seguinte:

- $75 \%$ dos pais acreditam que o controle de faixa etária dos novos jogos é importante. No entanto, os pais controlam o limite de tempo de uso dos games mais do que em qualquer outro tipo de entretenimento:

- $80 \%$ dos pais estabelecem tempo-limite para os jogos de videogame;

- $72 \%$ dos pais estabelecem tempo limite para o uso de internet;

- $71 \%$ dos pais estabelecem tempo limite para o uso da televisão;

- $65 \%$ dos pais estabelecem tempo limite para filmes

\subsection{3 - Produção de games no Brasil}

Até meados da década de 90, no Brasil, como acontece em toda a América Latina, não existia produção de grandes jogos comerciais. O investimento no mercado brasileiro de jogos eletrônicos não passava de $R \$ 170$ milhões (dados divulgados em palestra do então Ministro da Cultura, Gilberto Gil, na EGS 20046), onde a produção se resumia em comprar direitos autorais de jogos americanos para traduzir e vender no Brasil. Esse fato vem mudando e o Brasil apresenta uma força de trabalho especializada e capacitada para o universo de games, como vem ocorrendo na produção de desenhos animados. Várias empresas brasileiras especializadas em jogos para celular, web e multiplayer são requisitadas para prestar serviços para várias empresas multinacionais, "exportando" games, ou partes específicas de um projeto, produzidos aqui.

Um exemplo concreto do investimento externo na produção brasileira de games é a iniciativa da Ubisoft, empresa francesa responsável por várias franquias de games de sucesso, de montar o primeiro grande estúdio de desenvolvimento de games no Brasil. A exemplo do que aconteceu em Montreal, Canadá, após inaugurar um estúdio no centro cultural de Quebec, a Ubisoft formatou um pólo de desenvolvimento de games, incentivando a formação do profissional e a solidificação

\footnotetext{
${ }^{6}$ EGS 2004 - Eletronic Game Show 2004 foi a primeira edição brasileira de exposição de jogos eletrônicos, sucesso em alguns estados norte-americanos e no México. Contou com a presença de
} 
de uma cultura voltada para a produção de jogos. A idéia da empresa é fazer o mesmo na América Latina, começando por São Paulo, na produção de jogos para o Nintendo DS, com planos de extensão para a elaboração de jogos para Nintendo Wii, Playstation 3 e XBox $360^{7}$.

O país começa a se despertar para a formação de profissionais em games. Alguns cursos técnicos, de graduação e pós-graduação no eixo Sul-Sudeste e também no Nordeste estão em pleno vigor. Existem também vários grupos de pesquisa e de extensão nas universidades que integram estudantes das diversas áreas para compor uma equipe de desenvolvimento de games (programadores, engenheiros, designers, arquitetos, etc.). Abaixo, apresenta-se um infográfico que mostra os principais cursos de games no Brasil:

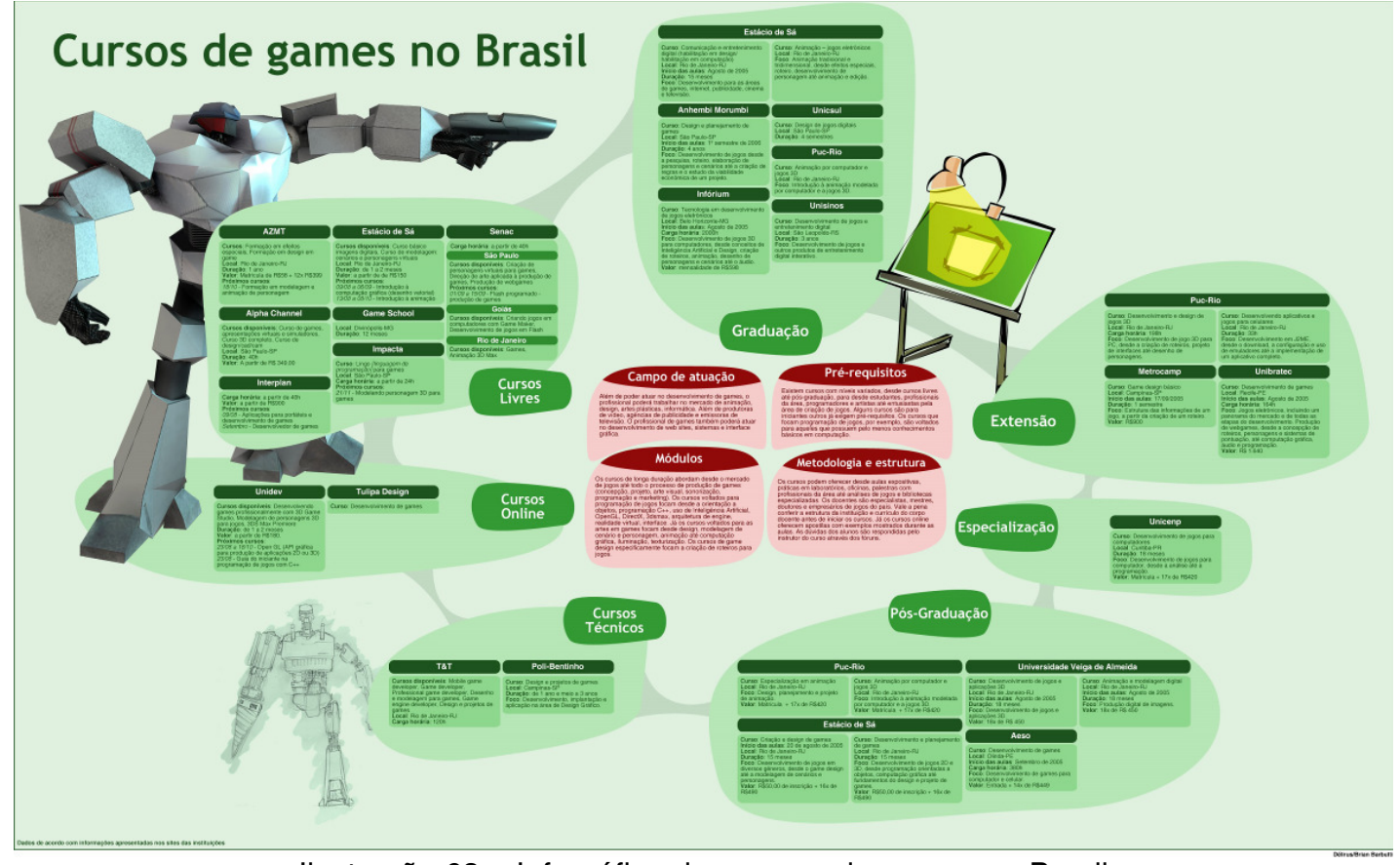

llustração 63 - Infográfico dos cursos de games no Brasil

Fonte: http://www.delirus.com.br/extras/infografico_cursos_game.jpg (Acesso em: 06 jan.2009)

Apesar de ainda estar nos primeiros passos, o Brasil mostra potencial crescente na produção de games. Espera-se que essa pesquisa acadêmica contribua para a valorização profissional dessa indústria que faz parte inexorável da formação do homem digital.

vários game designers e personalidades ilustres como o ministro da cultura, Gilberto Gil, realizado no Expo Center Norte, entre os dias 17 e 21 de novembro de 2004.

${ }^{7} \mathrm{http} / / /$ jogos.uol.com.br/reportagens/ultnot.2008/06/24/ult2240u128.jhtm 


\section{3 - Tipologia fluida dos games}

Para melhor compreender o universo dos games, é necessário investigá-lo quanto aos seus gêneros e construções, buscando entender as diversas plataformas lúdicas estabelecidas interativamente entre os jogadores, hardwares e softwares. Portanto, é necessário compreender as diferentes interfaces e estilos narrativos que existem quando se trata de jogos eletrônicos. A classificação por tipologia, no entanto, pode ser extremamente complexa e até impraticável, já que um jogo pode (e é até preferível) ser composto por diferentes interfaces. De fato, essa complexidade já se inicia na decisão do partido pelo qual se adota um sistema de classificação. É possível catalogar os games por idade indicativa, tipos de interfaces, popularidade, plataformas, narrativas desenvolvidas e até repercussão de vendas. $E$ em cada um desses partidos, é possível sub-classificar os jogos de forma tão detalhada e customizada ao ponto de chegar nas peculiaridades individuais de cada game. Em contraponto, é possível generalizar por plataformas, chegando nos jogos para computador, jogos para dispositivos portáteis, computadores, etc.

De qualquer forma, para compreender esse universo que pode ser generalista e detalhista, essa pesquisa adota dois distintos caminhos de classificação e tipologia sendo que o primeiro abarca aspectos gerais sobre qualquer manifestação lúdica (mostrando que todos os jogos eletrônico-digitais são, em si, tradicionalmente jogos), que considera mais a interface entre o homem e o jogo, e o segundo segue gêneros específicos encontrados só na ludicidade digital através dos games, em uma tipologia que considera a jogabilidade e narrativas propostas pelo jogo. Ambas as classificações em integração, ao generalizar e especificar, auxiliam na compreensão dos tipos de games.

\subsection{1 - Abordagem geral dos jogos}

A obra do intelectual francês Roger Caillois, "Os jogos e os homens" 8 (original de 1958), trabalha por construções da antropologia, psicologia e sociologia para

${ }^{8}$ CAILLOIS, Roger. Os jogos e os homens. Lisboa: Cotovia, 1990. 
apresentar os princípios elementares de qualquer jogo humano, independente de cultura, época, condições psicográficas, sociais ou materiais. Para o autor, todos os jogos podem ser classificados pelo nível e tipo de envolvimento social do(s) jogador(es) na prática lúdica.

Caillois classifica os jogos em quatro categorias:

- Agôn: são os jogos que promovem a competição onde regras, cenários e elementos geram um contexto de igualdade para os participantes, para que o vencedor se sobressaia por sua melhor preparação e capacidade. A maioria das competições esportivas podem, portanto, ser classificadas como agôn;

- Alea: em contraponto ao agôn, na alea estão os jogos onde os jogadores tem uma participação passiva, sem necessidades de preparo, habilidades ou qualidades específicas, predominando o acaso, destino ou sorte, ou seja, um "poder abstrato e insensível, a cujo veredito se submeteriam previamente, por diversão e sem reagir"9. São os jogos de azar de cassinos, loteria, etc.;

- Mimicry: jogos de representação onde os participantes atuam segundo a elaboração de personagens fictícios e/ou imitação, apropriando-se de outra realidade que não a sua. Um exemplo é a criança que imita o adulto ou um grupo de RPG (Role Playing Game), onde há a atuação de personagens;

- Ilinx: jogos que promovem a busca por vertigem e o abalo da estabilidade de percepção por parte dos órgãos sensoriais do corpo para atingir um estado de espasmo, transe e/ou afastamento súbito da realidade espaço-temporal sentida. Ocorre, mesmo que de forma limitada, nos parques de diversão e em jogos que exijam giros, volteios e trocas de direção.

Nota-se que, na generalização da classificação de Caillois, existe uma aplicação direta de seu conceito de interfaces lúdicas para o contexto dos games. Vários são os jogos de habilidades em que a competição entre jogadores e até entre jogador e máquina são o foco da jogabilidade. Desde jogos de corrida, lutas,

${ }^{9}$ Ibidem, p. 38. 
esportes e tiro, existe um repertório muito extenso de jogos que demandam a performance individual do jogador, caracterizando-se como jogos de agôn.

Sobre os jogos de azar e sorte, ou seja, dentro do contexto da alea, existem algumas adaptações diretas de jogos de cassino, cartas e apostas, mas não são quantitativamente significativos. O que existe mais efetivamente é uma aplicação randômica, onde a computação adota parâmetros aleatórios para nunca repetir uma situação. A "sorte" está embutida em cálculos matemáticos e em valores adotados randomicamente. Dessa forma, a possibilidade de que uma magia tire o máximo de energia do inimigo em um jogo de RPG, por exemplo, passa por um cálculo de "sorte e azar", ou melhor, cálculo randômico que determinará o dano causado.

Em quase todos os games existe o elemento de mimicry, pois em quase todos os casos, os participantes assumem o comando de um avatar, protagonista de um enredo e/ou ação, ou seja, assumem o papel de outro ser em uma abordagem de uma realidade não própria. Essa personificação alheia fica mais evidente em jogos de primeira pessoa, onde o jogador tem na tela o que seria a visão do personagem podendo até enxergar partes do seu próprio corpo como mãos e pernas. Mas quase na totalidade dos games existe a adoção de um papel fictício, mesmo que ele seja construído segundo parâmetros determinados pelo próprio jogador (como no caso dos RPGs). As poucas exceções ocorrem, por exemplo, em alguns jogos do Eye Toy, periférico do Playstation 2 da Sony que, com uma câmera, coloca os jogadores diretamente na tela da televisão para interagirem entre eles e com elementos virtuais. Nesse caso, por exemplo, os participantes podem ver os próprios corpos projetados na televisão enquanto lutam para não ficar com a batata quente que explodirá nas mãos do jogador menos atento.

Sobre as plataformas lúdicas que promovem o ilinx, as alterações sensoriais dos participantes sempre existiram através de efeitos visuais e sonoros para causar vertigens através de slow motion (efeito de câmera lenta), imagem embaçada e duplicada (para simular um atordoamento ou embriaguez), sobreposição muito rápida de imagens (desconcertando a percepção visual do jogador), entre outros. Mas para uma exploração mais integral dos elementos do ilinx, alguns fliperamas e máquinas de simulação movimentam o jogador, ativando suas percepções táteis e de equilíbrio e movimento. A aproximação de imersão total em ambientes virtuais (cavernas digitais) com os games também promovem uma alteração das percepções do usuário. 
Dessa forma, essa classificação de Caillois colabora na compreensão dos games como plataformas lúdicas que requisitam do jogador participações em diferentes níveis e qualidades de interação e interface enfocando na jogabilidade e nos aspectos lúdicos de prazer e diversão. Tal classificação, no entanto, não trata das questões das diferentes narrativas e dos aspectos educativos ou informativos dos jogos. Uma abordagem mais específica sobre os games contribui para compreendê-los nas suas propostas e possibilidades de formação.

\subsection{2 - Abordagem específica dos games}

Compreender os diferentes gêneros de games colabora na análise de seus potenciais de formação (seja através da apuração de sentidos, reflexos e respostas, seja na construção de conteúdo, isto é, no repasse de informações). Para isso, a lista do quadro abaixo padroniza as várias classificações encontradas em sites e revistas especializadas em games, na tentativa de expor uma breve descrição dos diversos gêneros, especificando a mecânica de funcionamento e listando as aplicações qualitativas em relação à formação do homem digital.

\begin{tabular}{|c|c|c|c|c|}
\hline Gênero & Descrição & $\begin{array}{c}\text { Mecânica de } \\
\text { funcionamento }\end{array}$ & $\begin{array}{l}\text { Aplicações } \\
\text { qualitativas }\end{array}$ & Exemplos \\
\hline Adventure & $\begin{array}{c}\text { Jogos baseados } \\
\text { em histórias, } \\
\text { geralmente } \\
\text { voltados em } \\
\text { solucionar } \\
\text { enigmas para } \\
\text { seguir com seu } \\
\text { curso }\end{array}$ & $\begin{array}{l}\text { Nem sempre são } \\
\text { em tempo-real } \\
\text { (híbrido com } \\
\text { ação); usam mais } \\
\text { o cérebro e } \\
\text { menos a destreza } \\
\text { e seus reflexos e } \\
\text { geralmente é } \\
\text { individual }\end{array}$ & $\begin{array}{c}\text { Incentivam } \\
\text { soluções de } \\
\text { puzzles e } \\
\text { promoção da } \\
\text { capacidade } \\
\text { criativa do jogador }\end{array}$ & $\begin{array}{l}\text { Wario: Master of } \\
\text { Disguise }\end{array}$ \\
\hline Ação & $\begin{array}{c}\text { Jogos em tempo } \\
\text { real onde o } \\
\text { jogador deve } \\
\text { responder com } \\
\text { velocidade ao que } \\
\text { está ocorrendo na } \\
\text { tela }\end{array}$ & $\begin{array}{l}\text { Dominado pelos } \\
\text { FPS (first } \\
\text { personal shooter } \\
\text { - jogo de tiro), é } \\
\text { menos intelectual } \\
\text { do que outros } \\
\text { gêneros, mas } \\
\text { ocorre geralmente } \\
\text { em grupo }\end{array}$ & $\begin{array}{c}\text { Promove a } \\
\text { destreza sensorial } \\
\text { e de reflexo, além } \\
\text { de incentivar a } \\
\text { competitividade } \\
\text { do jogador }\end{array}$ & Counter Strike Source \\
\hline RPG & $\begin{array}{l}\text { Geralmente o } \\
\text { jogador dirige um } \\
\text { grupo de } \\
\text { personagens em } \\
\text { alguma missão, } \\
\text { em diversas } \\
\text { tramas e cenários }\end{array}$ & $\begin{array}{l}\text { Grande universo } \\
\text { de jogo com } \\
\text { história linear; } \\
\text { sistemas de } \\
\text { evolução dos } \\
\text { poderes e forças } \\
\text { das personagens; } \\
\text { geralmente é } \\
\text { individual }\end{array}$ & $\begin{array}{l}\text { Exige o micro- } \\
\text { gerenciamento de } \\
\text { personagens: } \\
\text { escolha de } \\
\text { equipamentos e } \\
\text { armas; sistema de } \\
\text { magias amplo e } \\
\text { complexo }\end{array}$ & $\begin{array}{l}2{ }^{2} \\
\text { Final Fantasy } \mathrm{X}\end{array}$ \\
\hline
\end{tabular}




\begin{tabular}{|c|c|c|c|c|}
\hline Estratégia & $\begin{array}{c}\text { Gerenciamento } \\
\text { de recursos para } \\
\text { atingir } \\
\text { determinado } \\
\text { objetivo; } \\
\text { geralmente é a } \\
\text { construção de } \\
\text { unidades de } \\
\text { defesa e combate } \\
\text { em um contexto } \\
\text { de guerra }\end{array}$ & $\begin{array}{l}\text { Dois estilos: turn- } \\
\text { based (onde o } \\
\text { adversário espera } \\
\text { suas ações para } \\
\text { reagir, sendo } \\
\text { totalmente } \\
\text { mental) e RTS, ou } \\
\text { real time strategy, } \\
\text { exigindo reflexos } \\
\text { e agilidade e } \\
\text { estratégia no } \\
\text { controle de } \\
\text { tropas; o mais } \\
\text { usual é em } \\
\text { grupos e online }\end{array}$ & $\begin{array}{l}\text { Exige que os } \\
\text { jogadores } \\
\text { considerem o } \\
\text { balanceamento } \\
\text { das "variáveis"- } \\
\text { os recursos: como } \\
\text { obtê-los, como } \\
\text { adquirir unidades } \\
\text { e qual o custo- } \\
\text { benefício de cada } \\
\text { uma delas }\end{array}$ & 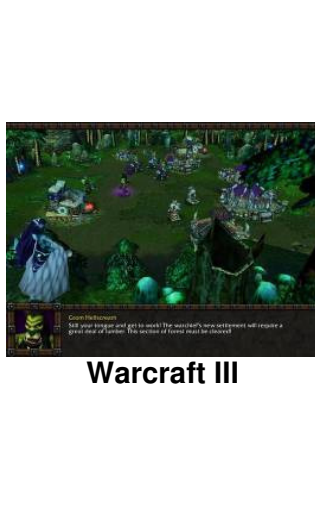 \\
\hline Simuladores & $\begin{array}{l}\text { Jogos que } \\
\text { simulam } \\
\text { condições do } \\
\text { mundo real, } \\
\text { principalmente } \\
\text { operação de } \\
\text { máquinas } \\
\text { complexas, como } \\
\text { aviões e carros }\end{array}$ & $\begin{array}{c}\text { Controles } \\
\text { direcionais e de } \\
\text { componentes } \\
\text { para competições } \\
\text { e práticas livres; } \\
\text { pode ser } \\
\text { individual ou em } \\
\text { grupo }\end{array}$ & $\begin{array}{l}\text { O realismo e a } \\
\text { precisão dos } \\
\text { controles das } \\
\text { máquinas e de } \\
\text { sua operação são } \\
\text { os principais } \\
\text { fatores }\end{array}$ & $\begin{array}{l}\text { Need for Speed } \\
\text { Carbon }\end{array}$ \\
\hline Esportes & $\begin{array}{l}\text { Jogos que } \\
\text { representam os } \\
\text { esportes "reais", } \\
\text { coletivos ou } \\
\text { individuais }\end{array}$ & $\begin{array}{c}\text { Simulam o } \\
\text { esporte tanto pelo } \\
\text { lado dos atletas } \\
\text { praticando o } \\
\text { esporte, quanto } \\
\text { pelo técnico, } \\
\text { gerenciando sua } \\
\text { equipe; pode ser } \\
\text { individual ou em } \\
\text { grupo }\end{array}$ & $\begin{array}{c}\text { Promove } \\
\text { principalmente a } \\
\text { destreza sensorial } \\
\text { e de resposta/ } \\
\text { reflexo }\end{array}$ & $\begin{array}{c}2009 \\
\text { Pro Evolution So }\end{array}$ \\
\hline Luta & $\begin{array}{l}\text { Controle de } \\
\text { personagens } \\
\text { através da } \\
\text { combinação de } \\
\text { movimentos e } \\
\text { manobras para } \\
\text { ataque e defesa } \\
\text { contra um } \\
\text { oponente }\end{array}$ & $\begin{array}{c}\text { Jogos geralmente } \\
\text { de vista lateral e } \\
\text { de curta duração, } \\
\text { com ampla } \\
\text { variedade de } \\
\text { personagens e } \\
\text { manobras; pode } \\
\text { ser individual ou } \\
\text { em dupla (um } \\
\text { contra o outro) }\end{array}$ & $\begin{array}{c}\text { Comandos } \\
\text { básicos de } \\
\text { ataques, defesas } \\
\text { e contra-ataques } \\
\text { de rápida } \\
\text { aprendizagem e } \\
\text { combinações } \\
\text { mais complexas } \\
\text { que exigem mais } \\
\text { prática e } \\
\text { velocidade }\end{array}$ & St \\
\hline Tabuleiro & $\begin{array}{l}\text { Adaptações dos } \\
\text { jogos tradicionais } \\
\text { como xadrez, } \\
\text { gamão e } \\
\text { paciência; inclui } \\
\text { também jogos dos } \\
\text { shows de TV }\end{array}$ & $\begin{array}{l}\text { Jogos de interface } \\
\text { simples auto- } \\
\text { explicativa, } \\
\text { geralmente } \\
\text { baseados em } \\
\text { interfaces de } \\
\text { jogos tradicionais }\end{array}$ & $\begin{array}{c}\text { Mesmas regras } \\
\text { dos jogos } \\
\text { tradicionais, mas } \\
\text { contra os cálculos } \\
\text { de um } \\
\text { computador }\end{array}$ & $\begin{array}{c}\text { Chessmaster: } \\
\text { Grandmaster Edition }\end{array}$ \\
\hline "God" games & $\begin{array}{l}\text { Chamados de } \\
\text { software toys, em } \\
\text { que não existe um } \\
\text { real objetivo além } \\
\text { do passatempo } \\
\text { de controlar } \\
\text { personagens e }\end{array}$ & $\begin{array}{l}\text { Através de uma } \\
\text { computação } \\
\text { baseada em } \\
\text { inteligência } \\
\text { artificial, alguns } \\
\text { comandos do } \\
\text { jogador } \\
\text { determinam }\end{array}$ & $\begin{array}{l}\text { Compreensão de } \\
\text { comportamentos } \\
\text { e situações } \\
\text { sociais }\end{array}$ & The Sims 2 \\
\hline
\end{tabular}




\begin{tabular}{|c|c|c|c|c|}
\hline & situações & $\begin{array}{c}\text { comportamentos } \\
\text { e respostas dos } \\
\text { personagens }\end{array}$ & & \\
\hline Educacionais & $\begin{array}{c}\text { Jogos cujo } \\
\text { objetivo é ensinar } \\
\text { enquanto se } \\
\text { diverte jogando }\end{array}$ & $\begin{array}{l}\text { Geralmente } \\
\text { voltados para o } \\
\text { público infantil, } \\
\text { utilizam uma } \\
\text { linguagem } \\
\text { semelhante à de } \\
\text { desenhos } \\
\text { animados }\end{array}$ & $\begin{array}{c}\text { O conteúdo } \\
\text { elaborado em } \\
\text { conjunto com } \\
\text { especialistas, } \\
\text { para que } \\
\text { realmente atinja o } \\
\text { objetivo de } \\
\text { ensinar brincando }\end{array}$ & Tabuada \\
\hline Puzzle & $\begin{array}{l}\text { Jogos puramente } \\
\text { voltados para o } \\
\text { desafio intelectual } \\
\text { na solução de } \\
\text { problemas }\end{array}$ & $\begin{array}{l}\text { Esse gênero é de } \\
\text { jogos de enigmas } \\
\text { e problemas } \\
\text { propriamente } \\
\text { ditos, sem } \\
\text { nenhum contexto } \\
\text { de história, } \\
\text { cenário ou outro } \\
\text { objetivo além da } \\
\text { solução dos } \\
\text { problemas }\end{array}$ & $\begin{array}{l}\text { Problema de } \\
\text { lógica, de } \\
\text { matemática ou } \\
\text { mesmo enigmas } \\
\text { filosóficos são } \\
\text { apreciados }\end{array}$ & $\begin{array}{l}\text { Return of the } \\
\text { Incredible Machine } \\
\text { Contraptions }\end{array}$ \\
\hline $\begin{array}{c}\text { Online/ } \\
\text { Massive } \\
\text { Multiplayer }\end{array}$ & $\begin{array}{c}\text { Jogado na } \\
\text { Internet; com } \\
\text { várias } \\
\text { participações; } \\
\text { geralmente se } \\
\text { aplica a RPGs } \\
\text { (MMORPG - } \\
\text { Massive } \\
\text { Multiplayer Online } \\
\text { RPG) }\end{array}$ & $\begin{array}{c}\text { Mecânicas } \\
\text { inerentes aos } \\
\text { diversos gêneros } \\
\text { aplicados para os } \\
\text { jogos em redes } \\
\text { para múltiplos } \\
\text { usuários }\end{array}$ & $\begin{array}{c}\text { Promove o } \\
\text { trabalho em grupo }\end{array}$ & $\sum_{\text {Ragnarok Online }}$ \\
\hline
\end{tabular}

llustração 64 - Tabela de classificação dos games por gênero

Fonte: Apostila de curso on-line da Unidev (www.unidev.com.br); imagens do site www.gamefaqs.com

(Acesso em: 06 jan.2009)

A classificação específica dos games nunca será suficiente para descrever detalhadamente as implicações de cada jogo, a não ser superficialmente. As classificações aqui apresentadas procuram colaborar na compreensão geral dos jogos digitais sem ter a pretensão de ter alcançado a descrição complexa existente nos jogos. Mesmo porque, nenhum jogo pode ser classificado em uma categoria apenas, mas contém aspectos de diversos gêneros. No entanto, a classificação dos games contribuem como base para as análises propostas na pesquisa.

A evolução histórica, o comportamento de consumo, os gêneros de games.. parece que tudo contribuiu para me apaixonar mais ainda por esse universo que faz parte da formação e existência do homem digital. E isso ocorre em mim, alguém que viveu a transição para o digital, ou seja sou um imigrante no mundo digital... imagine o que acontece com os nativos digitais?! 


\section{CAPÍTULO 4 - Análise prática: estudo de games}

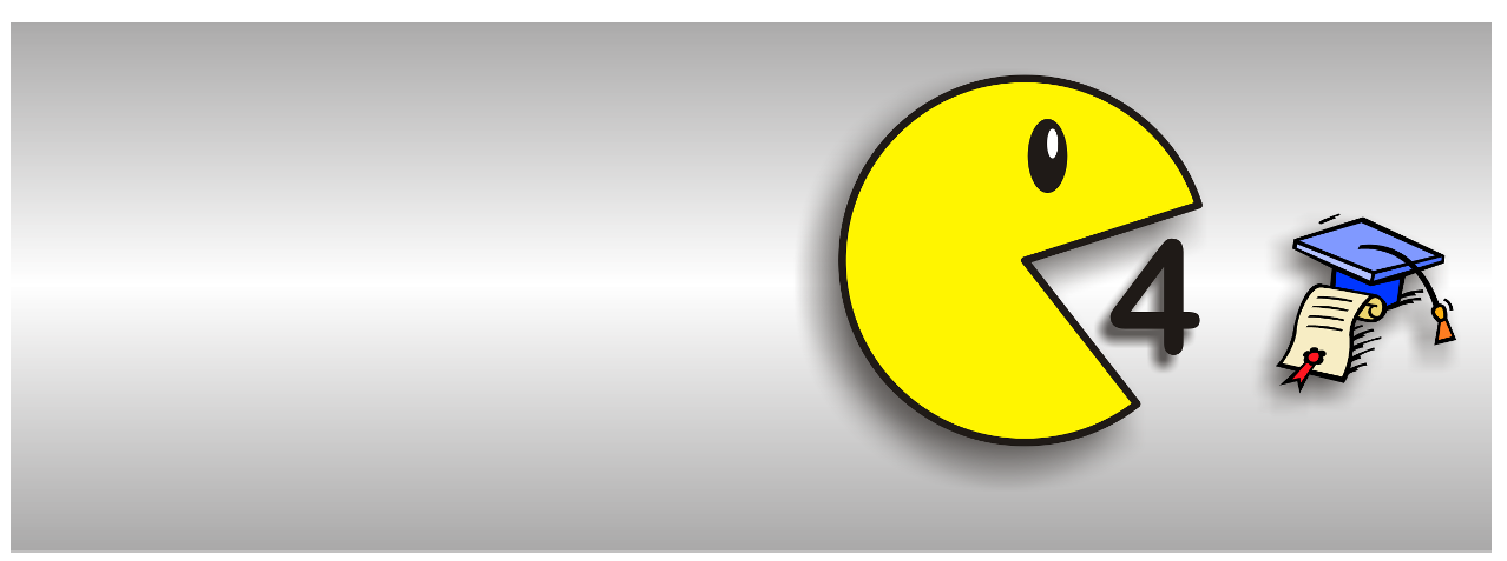




\section{CAPÍTULO 4 - Análise prática: estudo de games}

\section{Introdução ao capítulo}

Após um percurso teórico e analítico para compreender a relação inexorável e não instrumental entre homem e tecnologia, os aspectos lúdicos atrelados à educação e formação desse homem tecnológico, e um panorama geral da manifestação lúdica digital mais evidente - o game, chega o momento de analisar com mais profundidade a relação entre o homem e a sua formação lúdica pelos games, através do estudo em profundidade de alguns exemplos de jogos.

Para a análise dos games eleitos, existe a questão da opção metodológica para o desenvolvimento analítico mais objetivo e, portanto, mais científico e acadêmico. No entanto, a subjetividade da presença do pesquisador imerso (insider) compromete em parte a objetividade desejada e promove uma análise mais próxima à experimentação.

Os jogos selecionados buscam compreender os produtos lúdicos mais visados e/ou populares na comunidade dos gamers ou que tratem de questões específicas relevantes na presente pesquisa, tais como a interface homem e máquina, aspectos pedagógicos, interface entre jogador e jogo. A idéia é se afastar dos jogos voltados exclusivamente para a educação infantil e analisar jogos de sucesso e conteúdo, para extrair os aspectos educacionais, informativos e interfaciais que promovem a formação e a vivência experiencial do homem tecnológico.

\section{1 - Metodologia de pesquisa}

Os games passaram a ser foco de pesquisa muito recentemente e, portanto, não contam com modelos metodológicos de análise consolidados como é o caso da análise de filmes ou obras literárias. No entanto, a metodologia deve servir como roteiro de auxílio na busca de respostas para certas perguntas. No caso dos games, um sociólogo tende a observar os jogadores, enquanto um pesquisador de filmes tende a fazer uma análise de conteúdo e um pesquisador de comunicação foca as 
interações entre os jogadores entre si e com o game. O livro Understanding video games: the essential introduction ${ }^{1}$ apresenta algumas pesquisas e seus aspectos metodológicos e, portanto, auxilia na formulação de um método mais completo e estruturado para analisar os jogos aqui propostos.

Segundo os autores, em 2003 Dimitri Willianms publicou um estudo que buscava compreender a função do videogame no discurso das pessoas e a sua representação na maior parte das tendências culturais da época. Para tanto, pesquisou 119 artigos de jornais e revistas, não tomando como objeto de sua pesquisa os jogos ou jogadores, mas textos sobre o tema. Sua pesquisa demonstra como a opinião sobre os games, assim como sobre todas as novas tecnologias de comunicação, passa por uma fase de vilania para uma certa redenção, ou seja, como a percepção social sobre a cultura dos games é admitida pela sociedade.

Outro estudo - de Nicolas Ducheneaut, Robert J. Moore e Eric Nickell analisa o jogo multiplayer online Star Wars Galaxies: An Empire Divided buscando compreender como o jogo estimula a sociabilidade nos encontros dos jogadores e as relações desenvolvidas nas lan houses (cantinas). Para isso, ao pesquisadores utilizaram diversas metodologias:

- Etnografia virtual (gastando tempo no campo - observando sistematicamente a interação social nas cantinas);

- Gravação em vídeo das sessões de game inteiras (com uma câmera plugada no monitores);

- Registro (através de gravação) de todas as interações que ocorreram entre jogadores ao longo do jogo, e sua análise através de um software especialmente projetado para tal.

A conclusão do grupo de pesquisadores foi que os espaços públicos e presenciais das lan houses promoviam menos interação entre os jogadores do que o próprio jogo. Ou seja, a própria plataforma do game promovia mais conversas (por chat) e interações do que o ambiente presencial.

O livro relata ainda que Susana Tosca fez uma pesquisa detalhada sobre o jogo de terror Resident Evil X - Code: Verônica, um jogo onde os jogadores lutam contra zumbis e monstros e resolvem quebra-cabeças para tentar escapar de uma

\footnotetext{
${ }^{1}$ EGENFELDT-NIELSEN, Simon \& SMITH, Jonas H. \& TOSCA, Susana P. Understanding video games: the essential introduction. New York: Routledge, 2008.
} 
ilha amaldiçoada. Para tanto, a pesquisadora adotou uma abordagem de análise textual do jogo ressaltando pontos de relevância de sua construção e estrutura para compreender a sua narrativa implícita.

Os autores propõem, com base nessas diversas experiências de análise e ampliando a metodologia apresentada por Salen e Zimmerman ${ }^{2}$, uma aproximação aos jogos que considere os seguintes aspectos:

- JOGO: foco nos próprios jogos, analisando suas estruturas e como empregam algumas técnicas - recompensa do jogador, representação do jogador no mundo do game - com o intuito de incentivar a experiência do jogo através da sua jogabilidade.

- JOGADORES: em muitos casos, a atividade proporcionada pelo game é mais importante que o próprio game. Foca-se como os jogadores utilizam os games: como um tipo de mídia ou um espaço social (sociólogos e etnógrafos tendem a favorecer esse tipo de análise);

- CULTURA: ao invés dos próprios games, é possível optar focar mais amplamente a cultura da qual faz parte, buscando compreender como o jogo e o ato de jogar interagem com o padrão/modelo cultural mais amplo;

- ONTOLOGIA: alguns estudos analisam os fundamentos filosóficos dos games, buscando apresentar pontos gerais que se aplicam a todos os games, e permitem que se compreenda, por exemplo, a relação entre regras dos games, a ficção e o jogador.

A partir desses conceitos metodológicos apresentados, essa pesquisa propõe uma análise em profundidade que descreve os vários aspectos de cada jogo em sua estrutura técnica, jogabilidade, interfaces entre homem e computador e os aspectos pedagógicos que contribuem para a formação do homem digital. Para tanto, compilou-se o seguinte roteiro que pretende contemplar uma visão holística de cada jogo, inclusive extraindo os aspectos de formação:

\footnotetext{
${ }^{2}$ SALEN, K. \& ZIMMERMAN, E. Rules of Play: game design fundamentals. Londres: The MIT Press, 2004.
} 


\begin{tabular}{|c|c|c|}
\hline & Roteiro & Descrição \\
\hline \multirow{7}{*}{$\begin{array}{l}\frac{\infty}{\pi} \\
\frac{\pi}{0} \\
0 \\
0 \\
0 \\
0 \\
0 \\
0 \\
0\end{array}$} & Nome & O nome oficial do game \\
\hline & Plataforma/ console & $\begin{array}{l}\text { Plataforma do jogo: se é para computador, } \\
\text { dispositivos móveis, ou console, especificando } \\
\text { o modelo }\end{array}$ \\
\hline & Desenvolvimento & desenvolvedora do jogo \\
\hline & Distribuição & \begin{tabular}{|lll} 
Condições de distribuição & (preço \\
disponibilidade) &
\end{tabular} \\
\hline & Classificação etária & Faixa etária mínima recomendada \\
\hline & Data de lançamento & Desde quando o jogo está disponível \\
\hline & Site oficial & $\begin{array}{l}\text { Site ou hotsite oficial do jogo para mais } \\
\text { informações }\end{array}$ \\
\hline \multirow{4}{*}{ 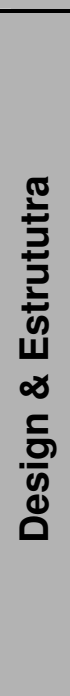 } & Gênero & $\begin{array}{l}\text { Utiliza-se a classificação elaborada sobre os } \\
\text { games do Capítulo } 3 \text { desta pesquisa com } \\
\text { breve descrição }\end{array}$ \\
\hline & $\begin{array}{l}\text { Interfaces } \\
\text { Jogabilidade }\end{array}$ & $\begin{array}{l}\text { Descrição das formas de interação entre } \\
\text { hardware, software e jogador relatando sobre } \\
\text { os elementos que promovem a jogabilidade }\end{array}$ \\
\hline & Objetivos & $\begin{array}{l}\text { Os objetivos referentes aos desafios } \\
\text { propostos no jogo }\end{array}$ \\
\hline & Narrativa & $\begin{array}{l}\text { A história e/ou narrativa que amarra todos os } \\
\text { desafios do jogo }\end{array}$ \\
\hline \multirow{3}{*}{ 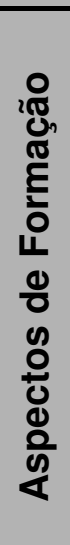 } & Ativação sensorial & $\begin{array}{l}\text { Todos os aspectos referentes aos estímulos } \\
\text { visuais, sonoros, sensitivos e intelectuais } \\
\text { promovidos pelo jogo ao jogador }\end{array}$ \\
\hline & Reflexo e resposta & $\begin{array}{l}\text { Todas as ações e reações de resposta e } \\
\text { reflexo do jogador exigidas pelo jogo }\end{array}$ \\
\hline & $\begin{array}{l}\text { Conteúdo } \\
\text { informacional }\end{array}$ & $\begin{array}{l}\text { As principais temáticas desenvolvidas no jogo } \\
\text { que exijam ou acrescentem informações } \\
\text { relevantes para a formação do ser digital }\end{array}$ \\
\hline
\end{tabular}




\begin{tabular}{|c|c|c|}
\hline 20 & Peculiaridades & $\begin{array}{l}\text { Descrição de pontos de curiosidade e } \\
\text { características próprias do jogo }\end{array}$ \\
\hline $\begin{array}{l}\frac{2}{0} \\
\frac{2}{0} \\
0\end{array}$ & Percepções do jogo & $\begin{array}{l}\text { Apontamento geral e conclusivo da percepção } \\
\text { geral do contato direto com a plataforma } \\
\text { lúdica }\end{array}$ \\
\hline
\end{tabular}

\section{2 - A escolha dos jogos}

Como já colocado anteriormente, os jogos escolhidos para análise não focam exclusivamente a função pedagógica, o que seria adotar um partido instrumental da tecnologia, onde o jogo ajuda no processo pedagógico. Pelo contrário, essa dissertação se baseia no conceito de que o homem se forma pela e com a tecnologia em um processo dialógico independentemente de qualquer foco educacional. Dessa forma, é muito mais importante analisar as principais manifestações lúdicas na era digital que apresentem boa repercussão e aceitação no mercado e/ou que tenham aspectos importantes para essa pesquisa. Como existem milhares de títulos, fez-se necessário escolher os mais significativos e inovadores reduzindo o universo em poucos exemplos analisados profundamente.

Dessa forma, as plataformas lúdicas escolhidas para análise, com breve justificativa da sua escolha, são:

- Brain Age: jogo que analisa, segundo critérios neurológicos, a idade cerebral do jogador e propõe exercícios diários para alcançar o ideal de 20 anos; seu sucesso no mercado foi tremendo pois, ao mesmo tempo que é divertido, explora aspectos de saúde neurológica ao trabalhar com a memória, capacidade de cálculo, lógica, etc;

- Spore: um jogo recém lançado (segundo semestre de 2008) onde o jogador experimenta controlar o desenvolvimento da vida, desde uma ameba até um conquistador espacial, passando pelo desenvolvimento físico, mental e social de acordo com as características de agressividade empregadas; é a integração mais completa entre jogador e jogo no desenvolvimento de um ser virtual vivente; 
- Ragnarök Online: um jogo MMORPG (Massive Multiplayer Online $\mathrm{RPG}$ ) onde vários jogadores interagem e formam alianças na busca de evoluir seus atributos e suas habilidades de combate contra monstros; não existem objetivos fixos além daqueles que cada jogador individualmente ou coletivamente adota como suas metas;

- Cozinheiro das Almas: jogo-arte totalmente brasileiro que, revisitando o livro "O Perfeito Cozinheiro das Almas deste Mundo", diário da garçonnière mantida por Oswald de Andrade entre 1918 e 1919, leva o jogador para uma viagem temporal complexa em um trama que tem a São Paulo de 1918 fundida com outros tempos como cenário; o mundo virtualmente construído apresenta uma pesquisa profunda sobre a cidade no começo do século XX;

- Blender: não é um jogo em si, mas um programa open source (código aberto) e gratuito para a modelagem e animação tridimensional de ambientes, personagens e objetos; seu diferencial está na engine (lógica de games) embutida em sua programação, ou seja, além de modelar a animar através de configurações simples, é possível montar um game inteiro; o processo de montar um game, por mais simples que seja, já é extremamente lúdico e pedagógico. 


\section{3 - Análise sobre o Brain Age}

\subsection{1 - Dados gerais}

\begin{tabular}{|c|c|}
\hline Nome & $\begin{array}{l}\text { Kawashima Ryuuta Kyouju Kanshuu Nou wo Kitaeru } \\
\text { Otona no DS Training (original - Japão); } \\
\text { Brain Age: Train Your Brain in Minutes a Day (EUA) }\end{array}$ \\
\hline Plataforma/ console & Game para o portátil Nintendo DS \\
\hline Desenvolvimento & Nintendo (Japão) \\
\hline Distribuição & $\begin{array}{l}\text { Preço médio de US\$19,99 (EUA), disponível nas } \\
\text { principais lojas de eletrônicos }\end{array}$ \\
\hline Classificação etária & Todas as idades \\
\hline Data de lançamento & 19/05/2005 (original - Japão); 17/04/2006 (EUA) \\
\hline Site oficial & http://www.brainage.com \\
\hline
\end{tabular}

Fonte: http://www.gametab.com/ds/brain.age.train.your.brain.in.minutes.a.day/5245/ (Acesso em: 08 jan.2009) 


\subsection{2 - Design e Estrutura}

\begin{tabular}{|c|c|}
\hline Gênero & $\begin{array}{l}\text { Educacional e puzzle: o jogo se caracteriza pelos desafios } \\
\text { intelectuais que promove e pelo enredo educativo que se } \\
\text { traduz na narrativa voltada para o desempenho cerebral do } \\
\text { jogador. }\end{array}$ \\
\hline $\begin{array}{l}\text { Interfaces e } \\
\text { Jogabilidade }\end{array}$ & $\begin{array}{l}\text { O jogo explora os vários recursos do Nintendo DS (portátil de } \\
\text { última geração da Nintendo), fazendo o jogador interagir com } \\
\text { os diversos desafios através da tela touch screen (seja } \\
\text { através de toques em partes específicas, seja através de } \\
\text { escrita e reconhecimento de caracteres), microfone } \\
\text { (reconhecimento de voz e fala) e botões. O game é jogado } \\
\text { com o console na vertical (com possibilidade de configuração } \\
\text { para destros e canhotos), diferentemente do modo usual de } \\
\text { utilizar o Nintendo DS, onde a grande maioria dos games são } \\
\text { jogados com as duas telas na horizontal. Os gráficos são } \\
\text { compostos por elementos bidimensionais (exceto pelo } \\
\text { narrador principal que é composto por uma construção } \\
\text { tridimensional) }\end{array}$ \\
\hline Obj & $\begin{array}{l}\text { O objetivo principal do jogo é promover o melhoramento para } \\
\text { o bom desempenho cerebral no que tange à memória, } \\
\text { capacidade de raciocínio lógico-matemático, assimilação } \\
\text { cognitiva e aprimoramento de reflexo. Com exercícios diários } \\
\text { e acompanhamento do desenvolvimento de performance, o } \\
\text { objetivo final é alcançar uma idade cerebral de } 20 \text { anos, } \\
\text { quando o cérebro está em seu ápice de desempenho. }\end{array}$ \\
\hline Narrativa & $\begin{array}{l}\text { Sempre acompanhado pelo Dr. Ryuta Kawashima, o narrador } \\
\text { do jogo, o jogador é convidado a aprimorar o desempenho de } \\
\text { seu cérebro com diversas atividades e desafios. É recheado } \\
\text { com informações sobre o funcionamento cerebral e a } \\
\text { importância de ativá-lo e estimulá-lo a fim de garantir a sua } \\
\text { longevidade e saúde. O jogo é dividido em três grandes } \\
\text { modalidades: a primeira, chamada "Quick Play" é o modo } \\
\text { casual (sem identificação ou acompanhamento programado), }\end{array}$ \\
\hline
\end{tabular}


onde qualquer jogador pode optar por checar a sua idade cerebral ou exercitar o cérebro com alguns puzzles; a segunda modalidade, chamada "Daily Training", exige uma identificação do jogador para um apropriado acompanhamento programado de performance e existe a abertura de mais puzzles e níveis de dificuldade conforme a evolução do jogador; a terceira modalidade envolve 120 puzzles de sudoku (jogo japonês de lógica numérica), divididos em 40 básicos, 40 intermediários e 40 avançados.

\subsection{3 - Aspectos de formação}

Considerando a estrutura do game, composto por diversos puzzles, e a metodologia de análise dos aspectos de formação (dividida em Ativação Sensorial, Reflexo e Resposta e Conteúdo Informacional), as descrições dos vários desafios intelectuais propostas no jogo serão distribuídas conforme o seu enfoque de formação, contendo uma justificativa da sua classificação no respectivo aspecto tecno-pedagógico.

Dessa forma, busca-se analisar o jogo de forma completa focando a sua mediação tecnológica na formação do ser digital, conforme o desenvolvimento teórico proposto nos primeiros capítulos dessa dissertação

\section{Ativação sensorial}

Aqui se encontram os puzzles que promovem a ativação e desenvolvimento de aspectos sensoriais, sensitivos e cognitivos com foco no aprimoramento das compreensões lingüísticas e lógicas matemáticas.

- WORD MEMORY (Memória de Palavras): Em dois minutos, o jogador tem uma lista de 30 palavras de 4 caracteres cada para memorizar; depois, tem três minutos para escrever todas as que lembrar (o puzzle existe somente no modo "Brain Age Check", checagem da idade cerebral). Nesse caso, o jogador ativa e desenvolve a sua capacidade de memorizar palavras através de associações livres e lingüísticas e, também, a lembrança recente. 


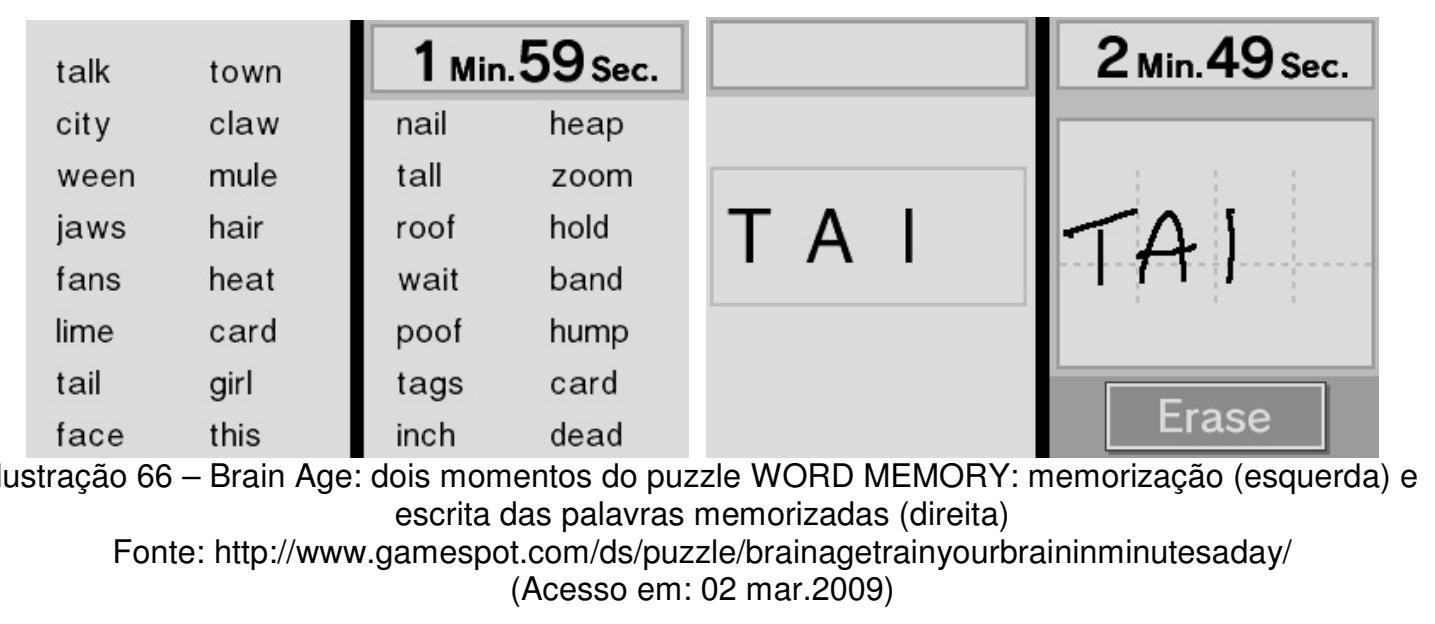

- SPEED COUNTING (Contagem Veloz): Contagem de 1 a 120 na maior velocidade possível; não há reconhecimento de fala, portanto o jogador deve ser honesto consigo mesmo (o puzzle existe somente no modo "Brain Age Check", checagem da idade cerebral). Neste puzzle, o jogador exercita e estimula a velocidade da sua lógica numérica ativando, ao mesmo tempo, a sua capacidade de concentração.

- READING ALOUD (Leitura em Voz Alta): O jogador deve ler o trecho de clássicos literários dados, da forma mais rápida possível; não há reconhecimento de fala, portanto o jogador deve ser honesto consigo mesmo (o puzzle existe somente no modo "Brain Training", treinamento cerebral). O jogador ativa a sua capacidade de leitura e de fala, ao mesmo tempo em que trabalha as conexões semânticas e literárias.

\begin{tabular}{l|l|}
$\begin{array}{l}\text { Ralph Waldo } \\
\text { Emerson: }\end{array}$ & $\begin{array}{l}\text { Next } \\
\text { Essays: First Series adored by } \\
\text { little statesmen } \\
\text { and philosophers } \\
\text { and divines. With } \\
\text { consistency a great } \\
\text { soul has simply } \\
\text { A foolish } \\
\text { consistency is the } \\
\text { hobgoblin of little }\end{array}$
\end{tabular}

Ilustração 67 - Brain Age: exemplo de texto do puzzle READING ALOUD Fonte: http://www.gamespot.com/ds/puzzle/brainagetrainyourbraininminutesaday/ (Acesso em: 02 mar.2009) 
- LOW TO HIGH (Do Menor Para o Maior): Números aparecem momentaneamente na tela para memorização e são ocultados em quadrados; o jogador deve tocar com a caneta nos quadrados revelando os números em ordem crescente; se conseguir tocar nos círculos na ordem correta, um novo conjunto aparece com mais números e assim vai até conjuntos de 10 números (o puzzle existe somente no modo "Brain Training", treinamento cerebral). O jogador é estimulado a desenvolver a ativar a sua capacidade de memorização (ao decorar os números) e de lógica numérica (ao organizá-los em ordem crescente).
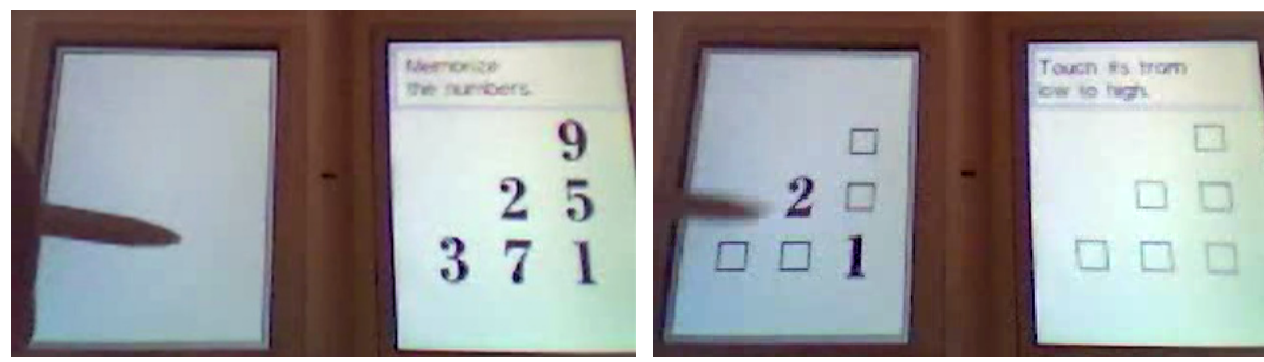

llustração 68 - Brain Age: dois momentos do puzzle LOW TO HIGH: memorização (esquerda) e escolha crescente dos números ocultos em quadrados (direita)

Fonte: http://www.youtube.com/watch?v=Bjro-alWelg (Acesso em: 02 mar.2009)

- SYLLABLE COUNT (Contagem de Sílabas): O jogador deverá contar as sílabas de 10 sentenças, no menor tempo possível (o puzzle existe somente no modo "Brain Training", treinamento cerebral). O puzzle estimula a capacidade de leitura do jogador, ao mesmo tempo em que exige o seu controle fonético-oral sobre frases escritas.

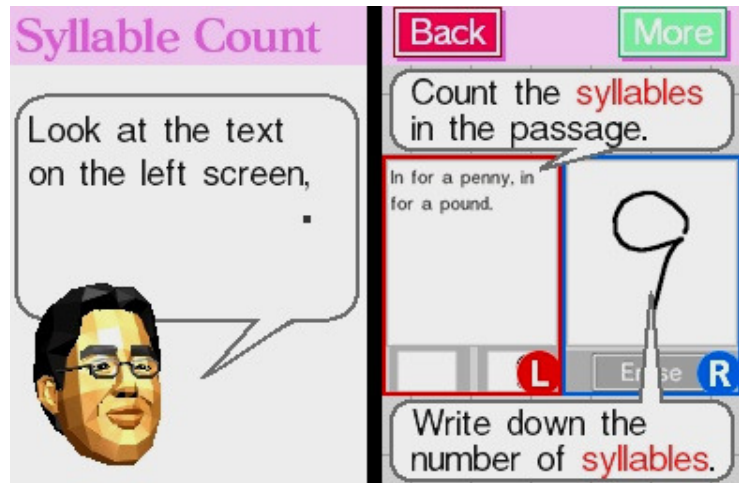

llustração 69 - Brain Age: exemplo de texto do puzzle SYLLABE COUNT Fonte: http://www.gamespot.com/ds/puzzle/brainagetrainyourbraininminutesaday/ (Acesso em: 02 mar.2009) 
- TRIANGLE MATH (Triângulo Matemático): O triângulo contém a primeira linha com três números e operações matemáticas de adição e subtração entre eles; a segunda linha contém dois espaços vazios de números resultantes das operações da primeira linha e mais uma operação entre eles; finalmente, a última linha contém o espaço para se colocar o resultado final, a resultante da operação da segunda linha; no modo difícil, são quatro números na primeira linha e, portanto, mais uma linha de operações (o puzzle existe somente no modo "Brain Training", treinamento cerebral). Nesse caso, o jogador ativa a sua capacidade lógico-matemática ao promover operações matemáticas simultâneas em duplas e/ou trios, além de estimular a visão periférica.

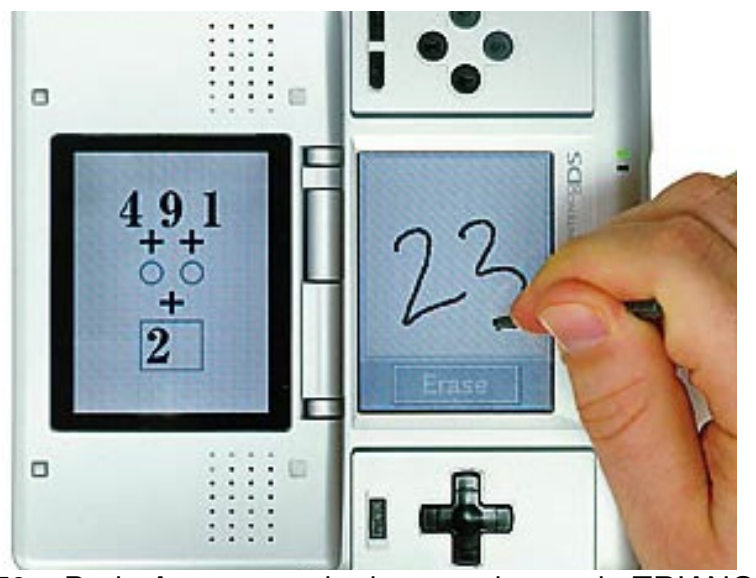

Ilustração 70 - Brain Age: exemplo de texto do puzzle TRIANGLE MATH

Fonte: http://veja.abril.com.br/100506/imagens/divertimento1.jpg (Acesso em: 02 mar.2009)

- TIME LAPSE (Lapso de Tempo): O jogador deverá dizer a diferença de horas e minutos entre dois relógios; o segundo relógio da operação se torna o relógio de referência, ou seja, o primeiro na próxima operação, quando aparece um novo relógio para uma nova medição de diferença (o puzzle existe somente no modo "Brain Training", treinamento cerebral). O jogador ativa e desenvolve a sua capacidade de transformar gráficos (desenho dos relógios) em informação (horário), ao mesmo tempo em que faz as contas de diferença das horas. 


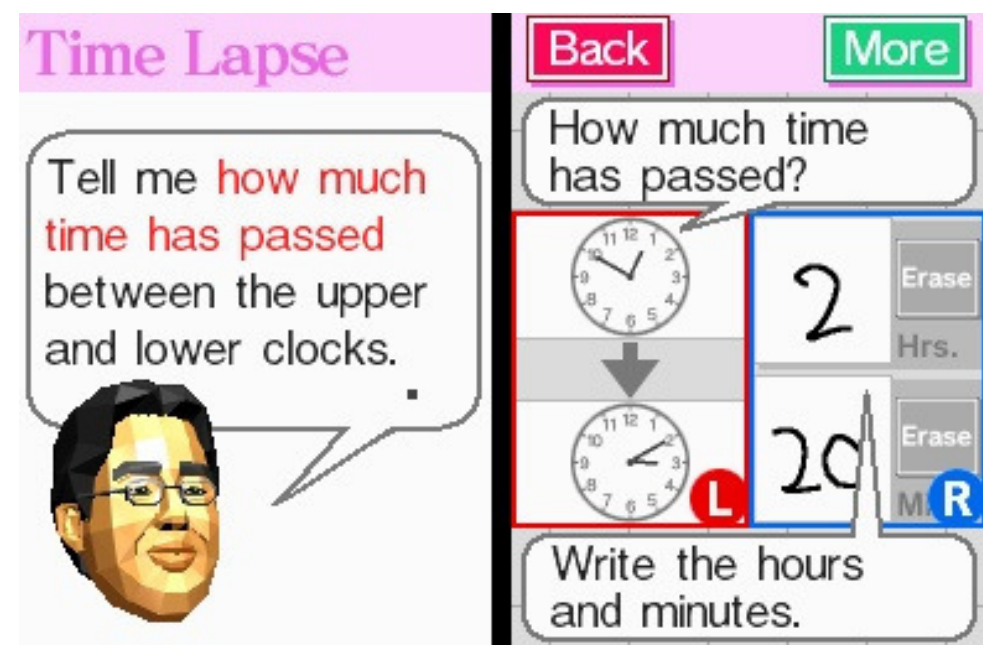

Ilustração 71 - Brain Age: exemplo de texto do puzzle TIME LAPSE

Fonte: http://www.gamespot.com/ds/puzzle/brainagetrainyourbraininminutesaday/

(Acesso em: 02 mar.2009)

\section{Reflexo e resposta}

Aqui se encontram os puzzles que promovem o reflexo e o tempo de resposta do jogador, enfocando no desenvolvimento da velocidade de reação do cérebro frente a desafios e estímulos específicos.

- STROOP TEST (Teste Stroop ${ }^{3}$ ): O jogador tem 50 palavras, nomes de cores (no caso, em inglês, "black", "blue", "red" e "yellow") impressas na tela com cores não correspondentes ao significado; o jogador deve dizer em menor tempo possível as cores da impressão e não o que está escrito e o mecanismo de microfone e reconhecimento de fala do console verifica o acerto (o puzzle existe somente no modo "Brain Age Check", checagem da idade cerebral). O jogador deve responder rapidamente ao estímulo de cor, desassociando-o do seu sentido literal, ou seja, condiciona o seu reflexo a receber a cor e não a ler o seu nome.

${ }^{3}$ O Teste Stroop, Desenvolvido por John Ridley Stroop, em 1935, baseia-se em evidências de que se leva mais tempo para nomear cores do que para ler nomes de cores. Assim, também se leva mais tempo para nomear a cor de impressão e/ou ler nomes de cores, quando esses se acham impressos em uma cor de tinta diferente da cor que nomeiam. Fonte: Stroop JR. Studies of interference in serial verbal reactions. Journal of Experimental Psychology, 18: 643-62, 1935. 


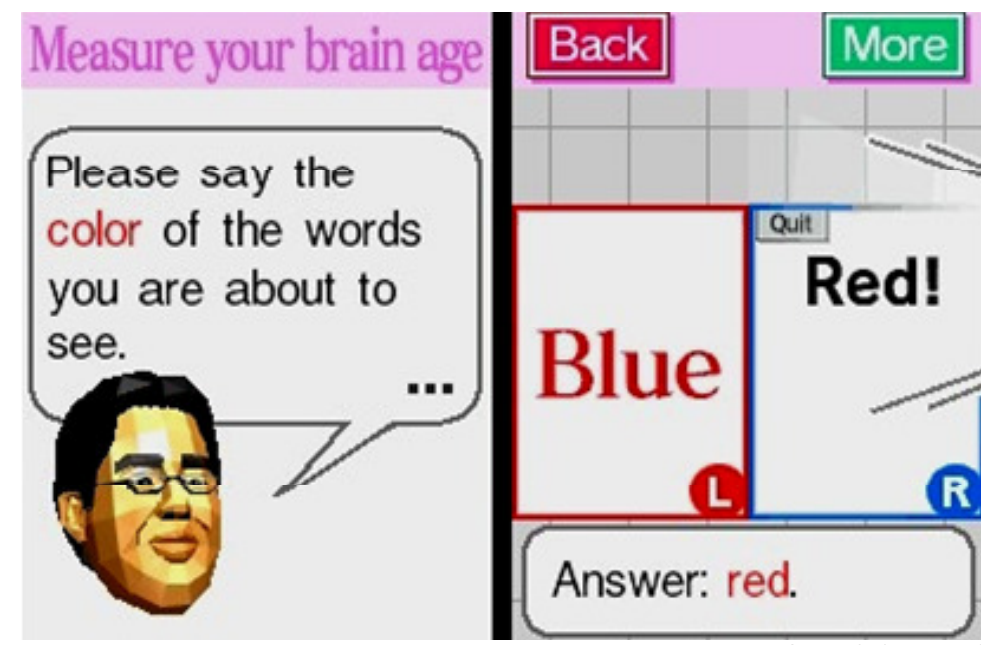

llustração 72 - Brain Age: exemplo de texto do puzzle STROOP TEST

Fonte: http://www.gamespot.com/ds/puzzle/brainagetrainyourbraininminutesaday/ (Acesso em: 02 mar.2009)

- CONNECT MAZE (Labirinto de Conexões): O puzzle consiste em uma tela com letras e números embaralhados onde o jogador deve conectar cada caractere em ordem crescente e intercalando abecedário e numeral, ou seja, conforme a seguinte ordem A-1-B-2-C-3-D-4-E-5-F-6G-7-H-8-I-9-J-10-K-11-L-12-M-13 (o puzzle existe somente no modo "Brain Age Check", checagem da idade cerebral). O jogador deve responder rapidamente a uma situação randômica e aparentemente caótica, organizando-a em uma associação crescente de letras e números.

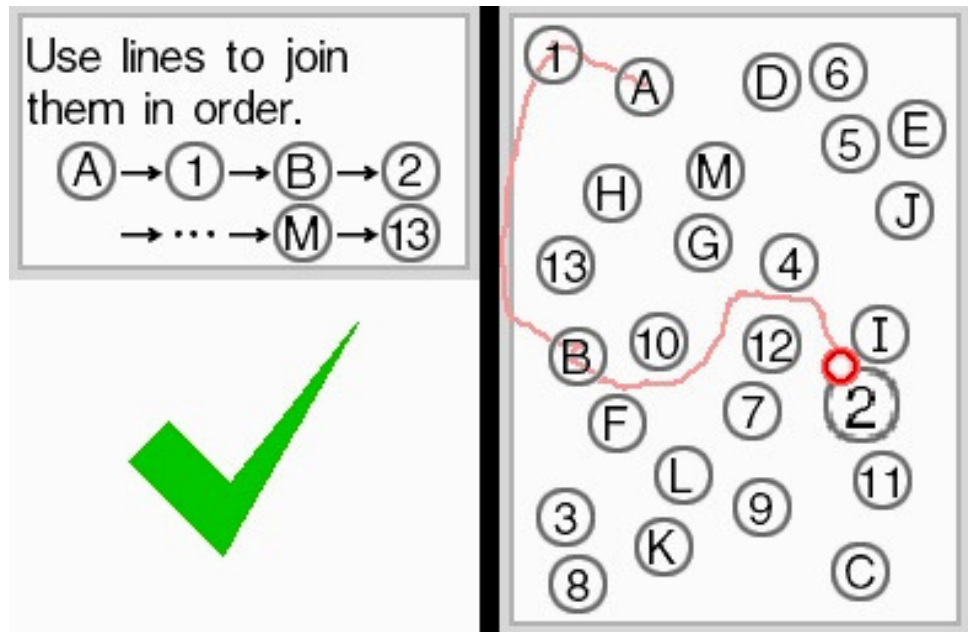

llustração 73 - Brain Age: exemplo de texto do puzzle CONNECT MAZE Fonte: http://www.gamespot.com/ds/puzzle/brainagetrainyourbraininminutesaday/ (Acesso em: 02 mar.2009) 
- NUMBER CRUNCHER (Depurando os Números): Vários números de diferentes valores, cores e movimentação estarão na tela e o jogador deve contar e responder a quantidade de números que existem com certas condições requisitadas no puzzle; por exemplo, deve-se responder quantos números "4" tem na tela, ou quantos "azuis", ou quantos estão em rotação, e assim por diante (o puzzle existe somente no modo "Brain Age Check", checagem da idade cerebral).

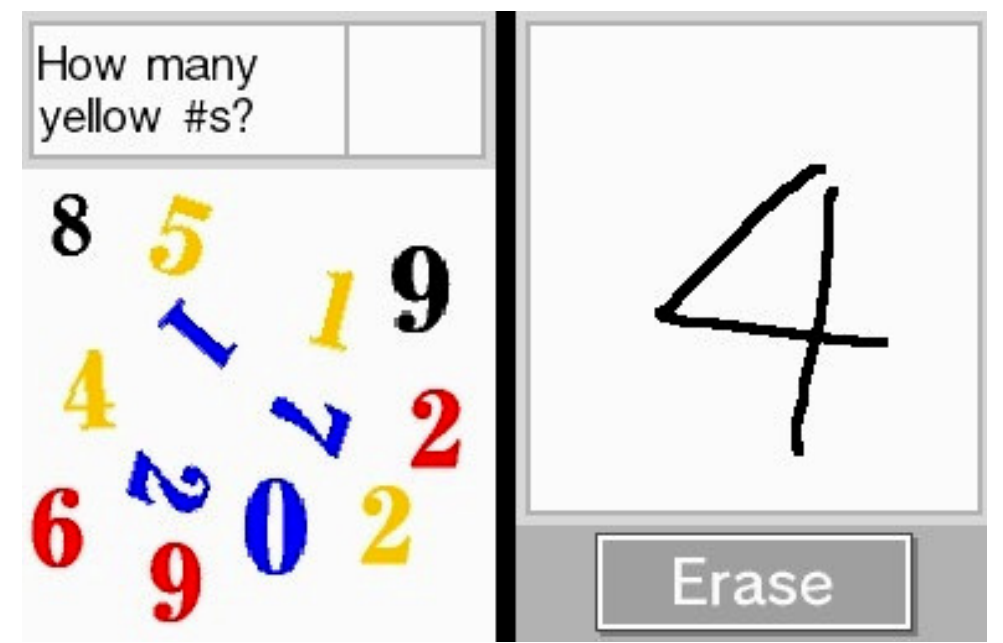

Ilustração 74 - Brain Age: exemplo de texto do puzzle NUMBER CRUNCHER Fonte: http://www.gamespot.com/ds/puzzle/brainagetrainyourbraininminutesaday/ (Acesso em: 02 mar.2009)

- CALCULATIONS X20 (20 Cálculos) e CALCULATIONS X100 (100 Cálculos): O jogador terá 20 e 100 cálculos de adição, subtração e multiplicação para resolver no menor tempo possível; no modo mais difícil, o jogador resolve também cálculos de divisão (o CALCULATIONS X20 existe no modo "Brain Age Check", checagem da idade cerebral e no modo "Brain Training", treinamento cerebral; 0 CALCULATIONS X100 só existe no modo "Brain Training"). O jogador deve responder rapidamente a desafios matemáticos, sendo exigido, ainda, que desenvolva a visão periférica (enquanto responde um cálculo, já deve observar o próximo cálculo) e a lógica matemática dupla (deve resolver vários cálculos simultaneamente). 


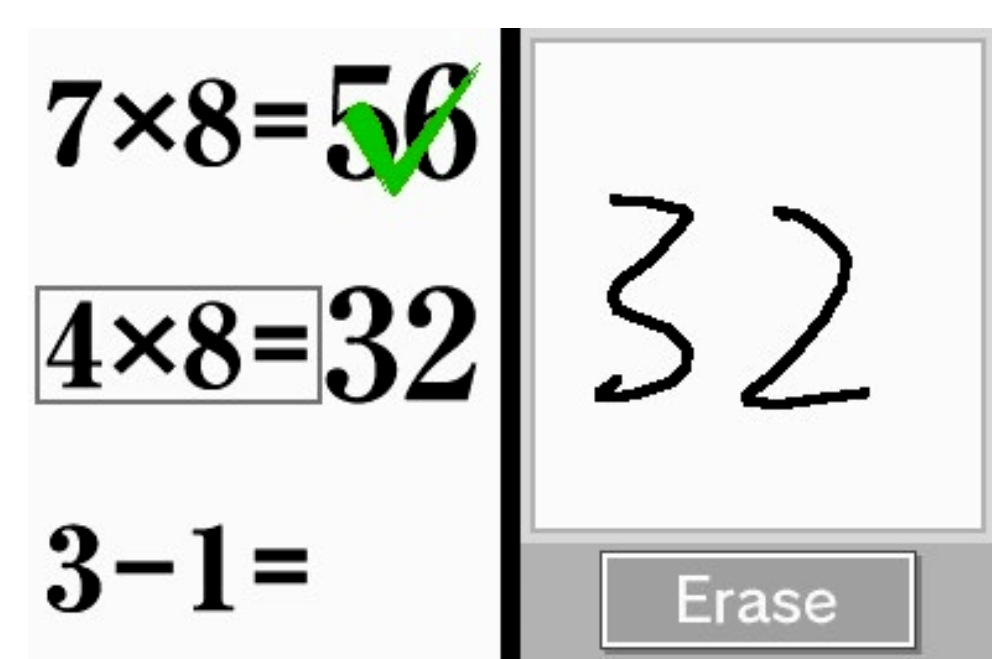

Ilustração 75 - Brain Age: exemplo de texto do puzzle CALCULATIONS X20 Fonte: http://www.gamespot.com/ds/puzzle/brainagetrainyourbraininminutesaday/ (Acesso em: 02 mar.2009)

- HEAD COUNT (Contagem de pessoas): O jogador deve dizer o número total de pessoas dentro da casa, considerando o número inicial e os entra e sai de pessoas; no começo as pessoas entram e saem pelas portas do fundo e da frente, mas no modo mais difícil, as pessoas também utilizam a chaminé (o puzzle existe somente no modo "Brain Training", treinamento cerebral). O jogador faz várias contas simultâneas ao mesmo tempo que o seu reflexo de contagem (bonecos que entram e que saem da casa) é requisitado a todo momento.

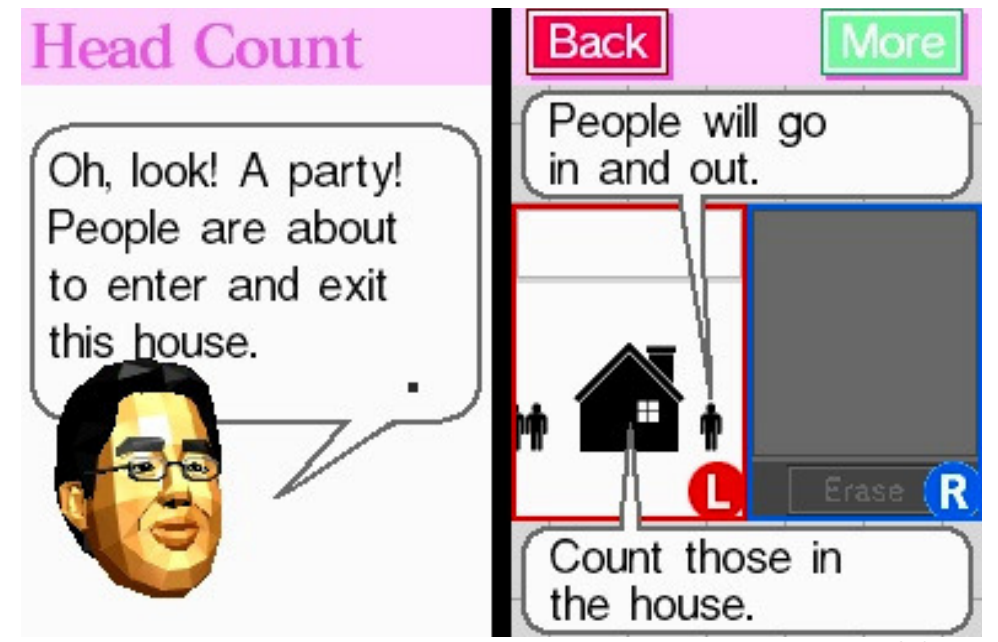

Ilustração 76 - Brain Age: exemplo de texto do puzzle HEAD COUNT

Fonte: http://www.gamespot.com/ds/puzzle/brainagetrainyourbraininminutesaday/ (Acesso em: 02 mar.2009) 
- VOICE CALCULATION (Cálculo por voz): O jogador tem 50 cálculos de adição, subtração, multiplicação e divisão para resolver, dando a resposta pela fala e, então, utilizando o mecanismo de reconhecimento de fala do console (o puzzle existe somente no modo "Brain Training", treinamento cerebral). Da mesma forma que os puzzles CALCULATION X20 e CALCULATION X100, o jogador deve responder rapidamente a desafios matemáticos, sendo exigido que, enquanto se responde um cálculo, já deve observar o próximo cálculo.

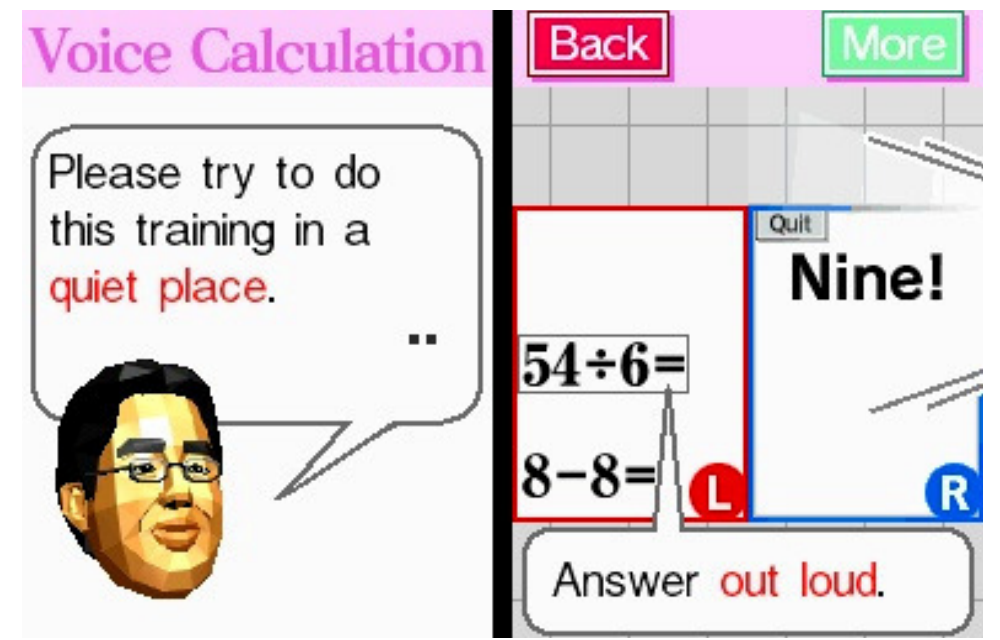

Ilustração 77 - Brain Age: exemplo de texto do puzzle VOICE CALCULATION Fonte: http://www.gamespot.com/ds/puzzle/brainagetrainyourbraininminutesaday/ (Acesso em: 02 mar.2009)

\section{Conteúdo informacional}

As principais contribuições em termos de conteúdo e informação encontradas no game estão na narração do Dr. Ryuta Kawashima que, durante as várias atividades e puzzles, sempre apresenta dados científicos e informações detalhadas de áreas cerebrais estimuladas por determinadas atividades e mostra os benefícios da prática diária dos desafios intelectuais. Com isso, o jogador tem a possibilidade de conhecer mais sobre o funcionamento do cérebro e se estimula a realizar as atividades propostas e a fazer o treinamento diário.

A seguir, uma seqüência de telas explicativas que passam informações sobre os estímulos cerebrais propostos pelo próprio game e que fazem parte da narrativa apresentada ao jogador. 


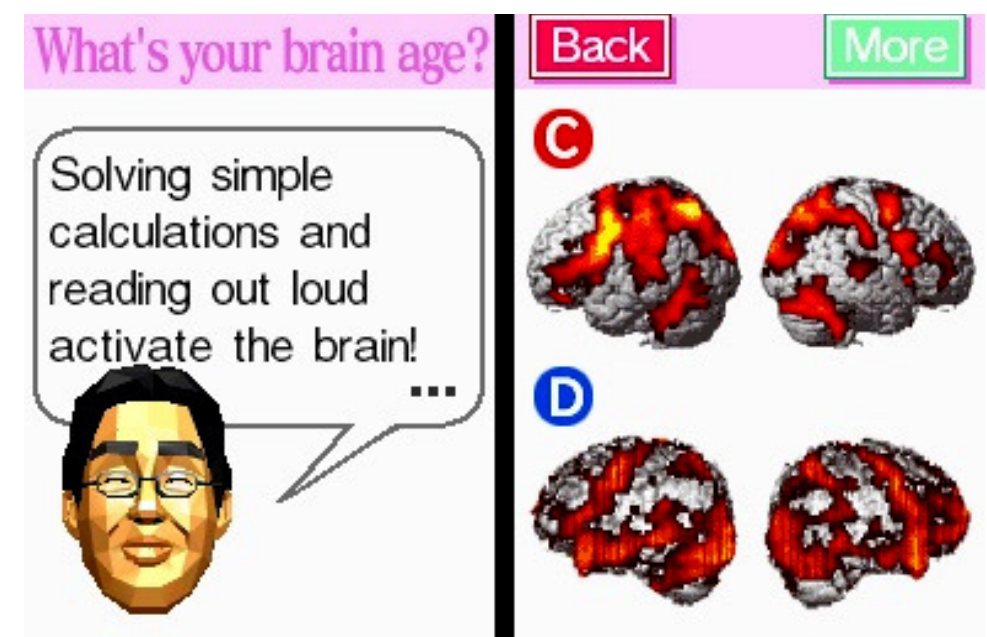

Tradução livre: "Resolver simples cálculos e fazer leituras em voz alta ativa o cérebro!..."

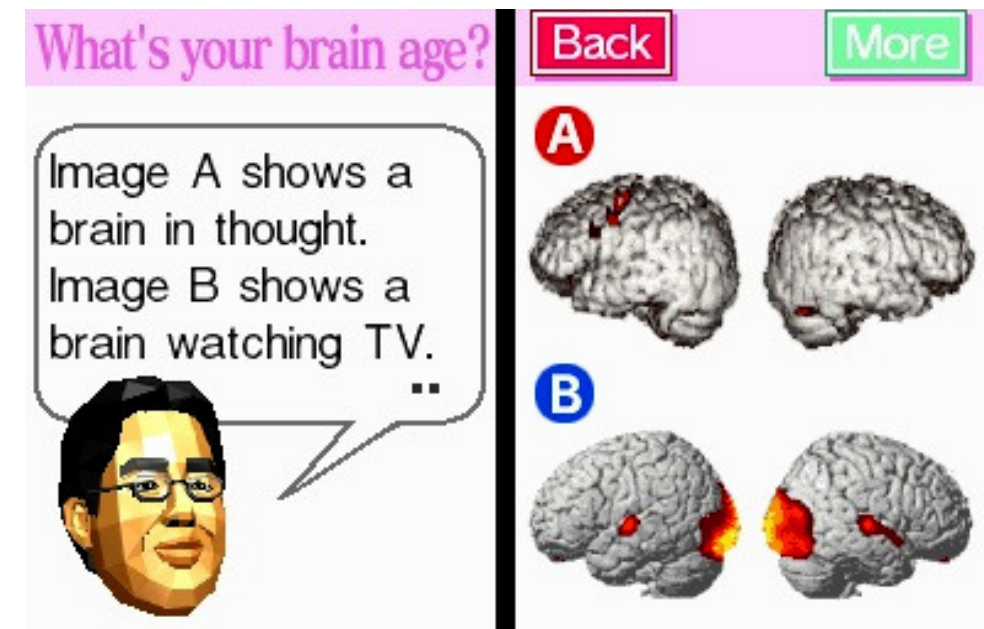

Tradução livre: "A imagem A mostra um cérebro de alguém pensando. A imagem B mostra um cérebro de alguém assistindo à TV..."

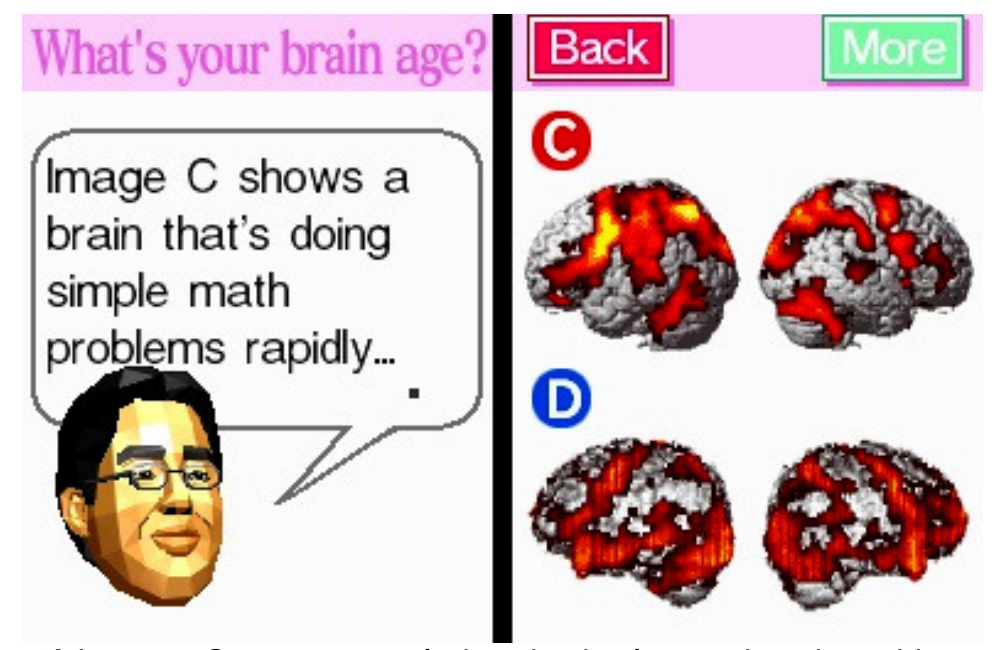

Tradução livre: "A imagem $\mathrm{C}$ mostra um cérebro de alguém resolvendo rapidamente problemas simples de matemática..." 


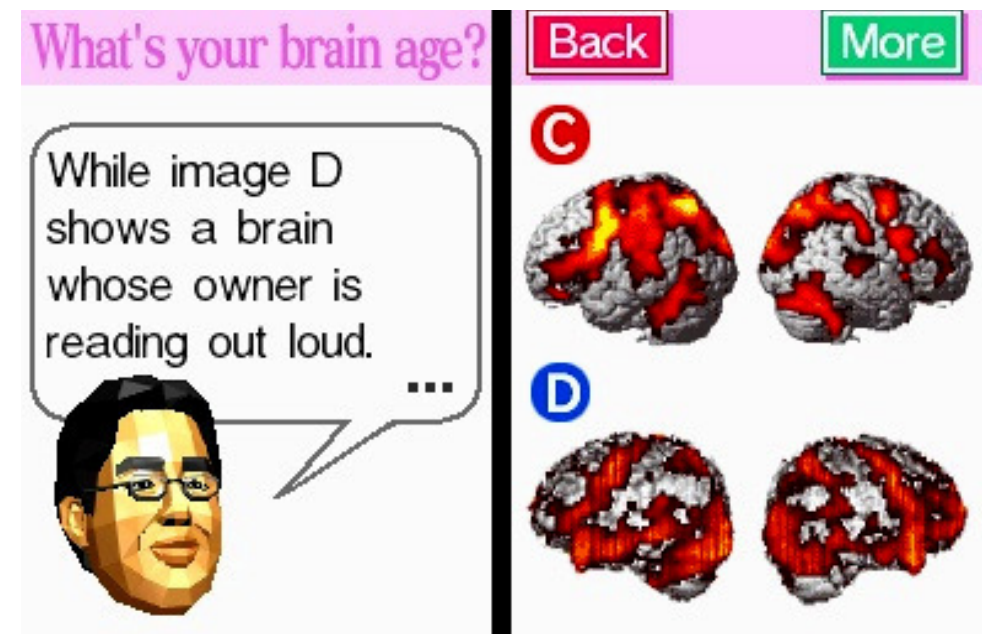

Tradução livre: "Enquanto a imagem D mostra um cérebro de alguém que está lendo em voz alta."

Ilustração 78 - Brain Age: seqüência de telas explicativas do BRAIN AGE Fonte: http://www.gamespot.com/ds/puzzle/brainagetrainyourbraininminutesaday/

(Acesso em: 02 mar.2009)

$\mathrm{Na}$ descrição do game encontrado na sua embalagem e também no site existe a observação de que todos os dados científicos apresentados são baseados em pesquisas reais e confiáveis de institutos específicos de estudo da atividade cerebral e que todas as atividades e puzzles, elaborados com o mesmo rigor científico, têm eficiência comprovada. Desse modo, o jogador é estimulado a sempre exercitar o cérebro a partir dos puzzles propostos, com o reforço das informações sobre a saúde cerebral e a importância de seu constante exercício.

Só uma pequena e insignificante observação: qualquer semelhança entre o Dr. Ryuta Kawashima e o autor dessa dissertação é mera coincidência!

\subsection{4 - Conclusão}

\section{Peculiaridades}

O jogo apresenta uma exploração completa sobre as interfaces do console portátil Nintendo DS, exigindo que o jogador interaja com os desafios intelectuais através da tela touch screen por meio do toque direcionado e da tecnologia de escrita e reconhecimento de caracteres e através do microfone e da tecnologia de reconhecimento de fala.

O público-alvo são os adultos, mas o jogo diverte e é eficiente para todas as idades e o seu sucesso ocorre em várias faixas etárias. Tanto é que o jogo já 
ganhou uma segunda versão ("Brain Age2: More Training in Minutes a Day!"), lançado em agosto de 2007, com novos desafios e puzzles.

O puzzle CALCULATION X20 pode ser jogado em um desafio multiplayer onde até 16 jogadores, que tenham o jogo, podem competir entre si na solução mais rápida dos cálculos. Além disso, existe espaço para vários jogadores se inscreverem no modo "Daily Training", ou "Treinamento Diário", tendo desenvolvimento e acompanhamento programado de forma independente. Dessa forma, uma cópia do game pode ser jogada por vários jogadores e eles podem jogar entre si.

No final de cada atividade é dada uma pontuação com uma animação que faz analogia ao desempenho apresentado: se foi um desempenho insuficiente, aparece a animação de uma pessoa andando; se o desempenho foi excelente, aparece a animação de uma nave espacial. Dessa forma o jogador é "premiado".

\section{Percepções do jogo}

Apesar de utilizar um console de videogame, o jogo tem apelo educativo claro, sendo que o enfoque é sempre é no condicionamento cerebral. Por outro lado, mesmo não tratando diretamente sobre questões lúdicas, o game apresenta puzzles e desafios que instigam o jogador a melhorar a sua performance e, conforme o seu desenvolvimento, a ser premiado com melhores colocações de desempenho (lembrando que, no jogo, a idade cerebral ideal é de 20 anos). Tais elementos de desafio, premiação e competição fazem emergir os aspecto lúdicos do jogo e demonstram como ludicidade e pedagogia se integram ao ponto de não existir uma diferenciação possível. 


\section{4 - Análise sobre o Spore}

\subsection{1 - Dados gerais}

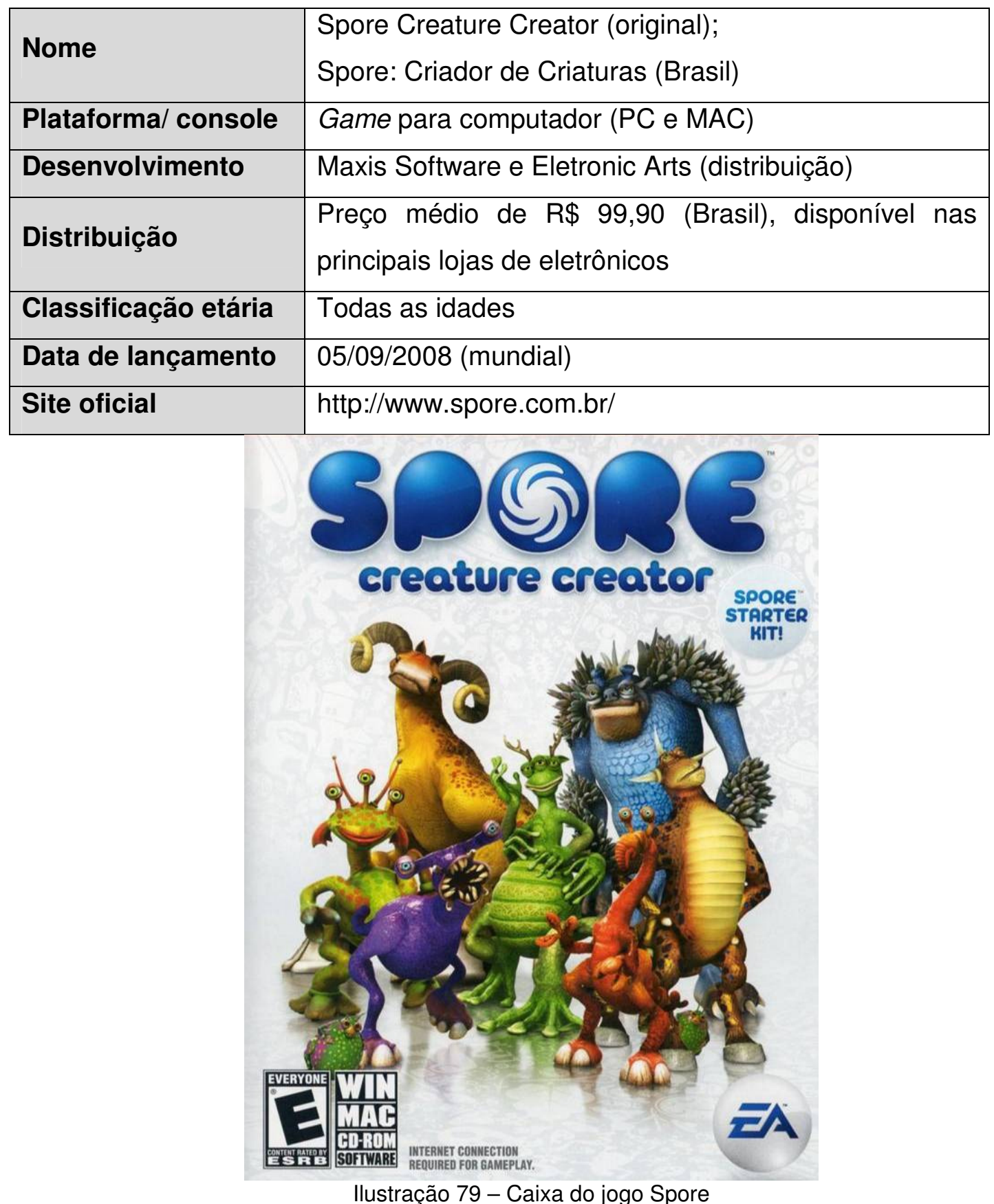

Fonte: http://www.gamefaqs.com/computer/doswin/image/949627.html (Acesso em: 08 jan.2009) 


\subsection{2 - Design e Estrutura}

\begin{tabular}{|c|c|}
\hline Gênero & $\begin{array}{l}\text { RPG, Estratégia e "God" game: o jogo reúne várias ações e } \\
\text { interfaces que vão desde o desenvolvimento de criaturas com } \\
\text { sistema de evolução típico dos role playing game, } \\
\text { gerenciamento de recursos para comandar batalhões e } \\
\text { sociedades organizadas em estratégia de tempo real e } \\
\text { interação despretensiosa com a inteligência artificial da } \\
\text { plataforma como acontece nos "god" games. }\end{array}$ \\
\hline $\begin{array}{l}\text { Interfaces e } \\
\text { Jogabilidade }\end{array}$ & $\begin{array}{l}\text { O jogo é controlado pela interação entre mouse e teclado, já } \\
\text { que a interface tridimensional exige uma visualização com } \\
\text { variação de zoom, rotação e translação que podem ser } \\
\text { alterados com a movimentação do mouse e botões de } \\
\text { comando acionados (Control, Alt, Shift, etc.). Os gráficos } \\
\text { tridimensionais são sofisticados e permitem três níveis de } \\
\text { detalhamento, dependendo do desempenho de } \\
\text { processamento da placa de vídeo do computador onde o jogo } \\
\text { foi instalado. Existem várias telas de ajuda e as informações } \\
\text { de status do personagem (vida e saúde, energia e nível } \\
\text { evolutivo) e dos recursos (dinheiro, alimento, missões, } \\
\text { avisos) estão permanentemente na tela de interface em uma } \\
\text { composição visual intuitiva e bem organizada. É possível } \\
\text { compartilhar criaturas e objetos criados (automóveis, } \\
\text { construções) pela internet através da Sporepedia, espécie de } \\
\text { enciclopédia do Spore, onde todos os jogadores cadastrados } \\
\text { podem enviar e compartilhar as suas criações. O próprio jogo } \\
\text { utiliza dessa biblioteca para montar e personalizar em } \\
\text { infinitas possibilidades os jogos. }\end{array}$ \\
\hline Objetiv & $\begin{array}{l}\text { O grande desafio que existe do jogo é vivenciar e influenciar } \\
\text { na evolução de uma espécie desde a sua forma de ameba } \\
\text { até o seu completo amadurecimento quando alcança a } \\
\text { tecnologia que possibilita a exploração espacial e a interação } \\
\text { com outros impérios galácticos. Tal evolução acontece } \\
\text { através do seu comportamento em relação ao ambiente e às }\end{array}$ \\
\hline
\end{tabular}




\begin{tabular}{|l|l|}
\hline outras criaturas que vai determinando as possibilidades de \\
membros especializados (garras para predadores e patas \\
com habilidade de dança para espécies com vocação \\
socializante) e desenvolvimento tecnológico (armas para as \\
culturas guerreiras e publicidade para as nações que optam \\
pela influência pacífica). \\
\hline $\begin{array}{l}\text { O jogo é dividido em cinco principais fases que, de forma } \\
\text { histórica e linear, vão se influenciando e promovendo } \\
\text { aspectos e formatos específicos e personalizados para cada } \\
\text { jogador, sendo que para cada vez que for jogar, encontrará } \\
\text { diferentes desafios e características. As fases são: estágio de } \\
\text { célula, estágio de criatura, estágio tribal, estágio de } \\
\text { civilização e estágio espacial. Nos estágios de célula e de } \\
\text { criatura o jogador junta pontos de DNA (espécie de moeda } \\
\text { genética adquirível indefinidamente) e traços genéticos } \\
\text { específico (que vão abrir novas possibilidades de membros } \\
\text { especializados na janela de evolução) para desenvolver a } \\
\text { criatura com membros que podem ser colocados em } \\
\text { qualquer posição e atribuindo cores e texturas em uma } \\
\text { personalização completa. Já nos estágios tribal, de } \\
\text { civilização e espacial, o jogador cria automóveis e } \\
\text { construções (casas, fábricas, etc.) para a sua expansão no } \\
\text { mundo e no universo. }\end{array}$ \\
\hline
\end{tabular}

\subsection{3 - Aspectos de formação}

O Spore pode ser analisado, em termos da formação que promove, pela ativação sensorial que existe na interface de criação de criaturas e construções e nas missões propostas, pelo reflexo e resposta exigido na interação com outras criaturas e civilizações e pelo conteúdo informacional que depende da integração do desenvolvimento personalizado do jogo e as questões do evolucionismo de Darwin. 


\section{Ativação sensorial}

Realiza-se aqui uma breve descrição de cada fase do jogo, com a observação de que a ativação sensorial visual e intelectual ocorre principalmente na composição das criaturas e construções, além da elaboração de estratégias.

No estágio de célula, a primeira tarefa a se realizar é a escolha e nominação do planeta onde vai começar a surgir a sua criatura. Um meteoro cai no seu novo planeta e, na sua explosão no oceano, libera elementos celulares orgânicos que encontram as condições ideais para se desenvolver.

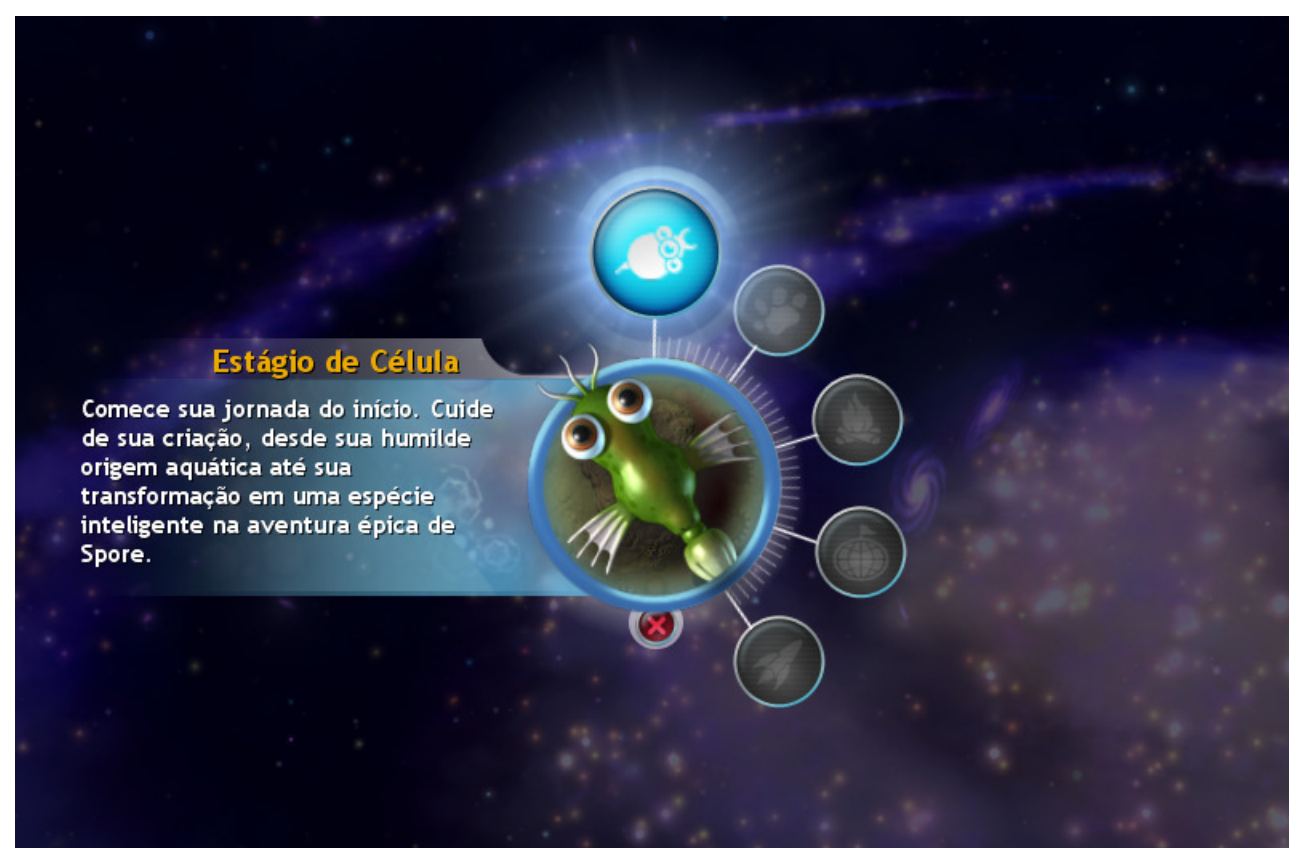

Ilustração 80 - Spore: abertura do Estágio de Célula

Fonte: Produção própria (durante pesquisa exploratória do jogo)

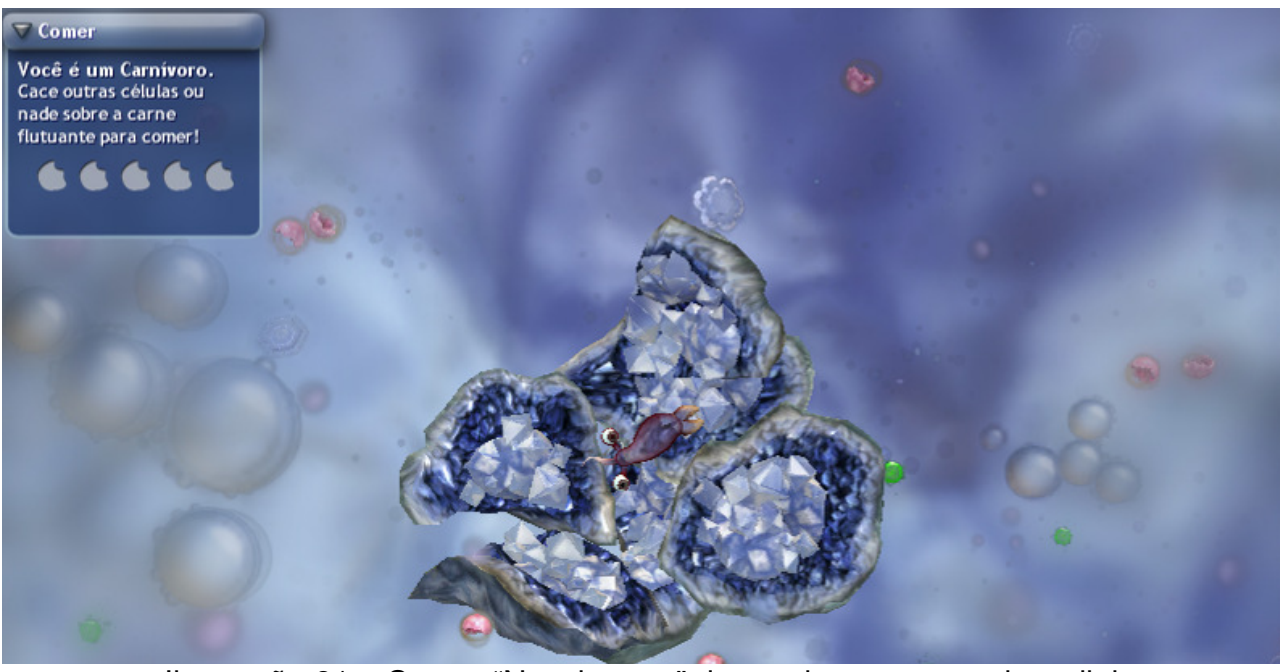

llustração 81 - Spore: "Nascimento" da ameba na poça primordial

Fonte: Produção própria (durante pesquisa exploratória do jogo) 
Nessa fase amebóide já é possível atribuir a principal característica alimentar da criatura que deverá ser definida como herbívora, carnívora ou onívora. Dependendo da escolha, o jogador terá à disposição membros especializados em caça a outras amebas ou na nutrição vegetal.

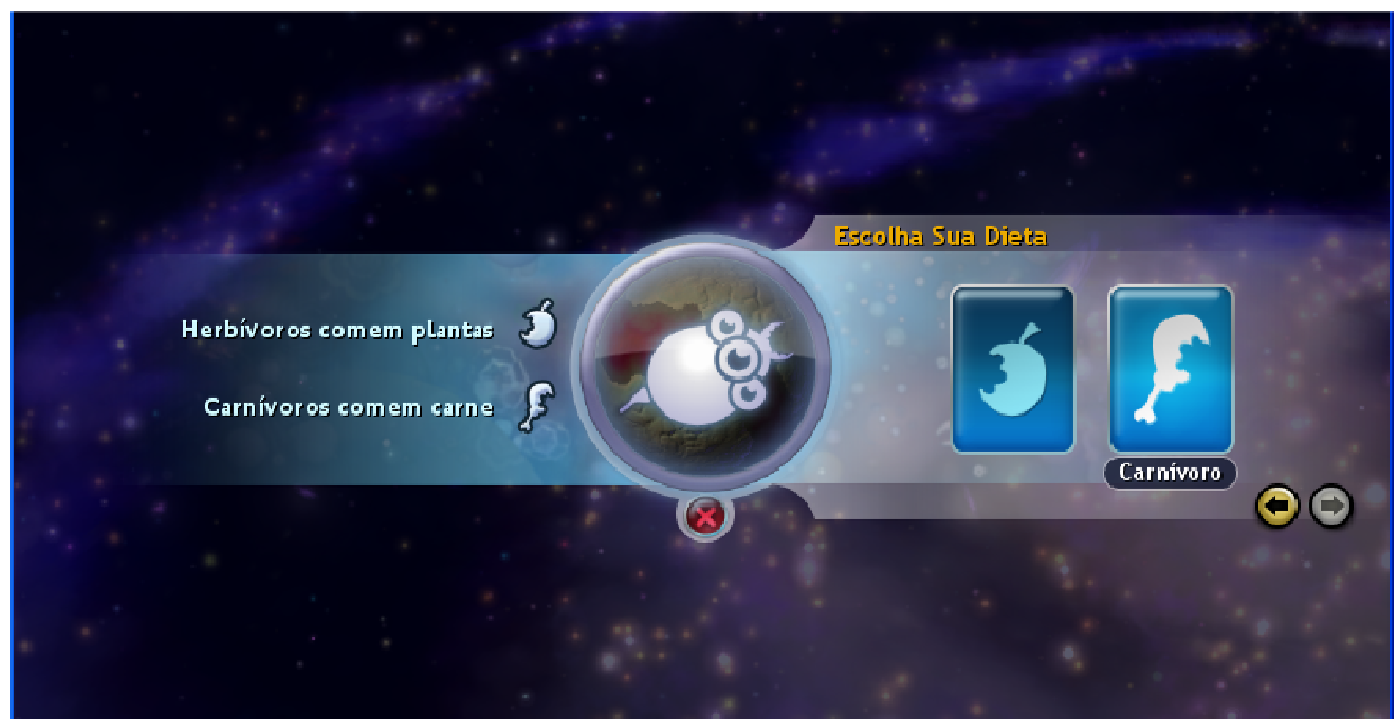

Ilustração 82 - Spore: caracterização da dieta alimentar da ameba no Estágio de Célula Fonte: Produção própria (durante pesquisa exploratória do jogo)

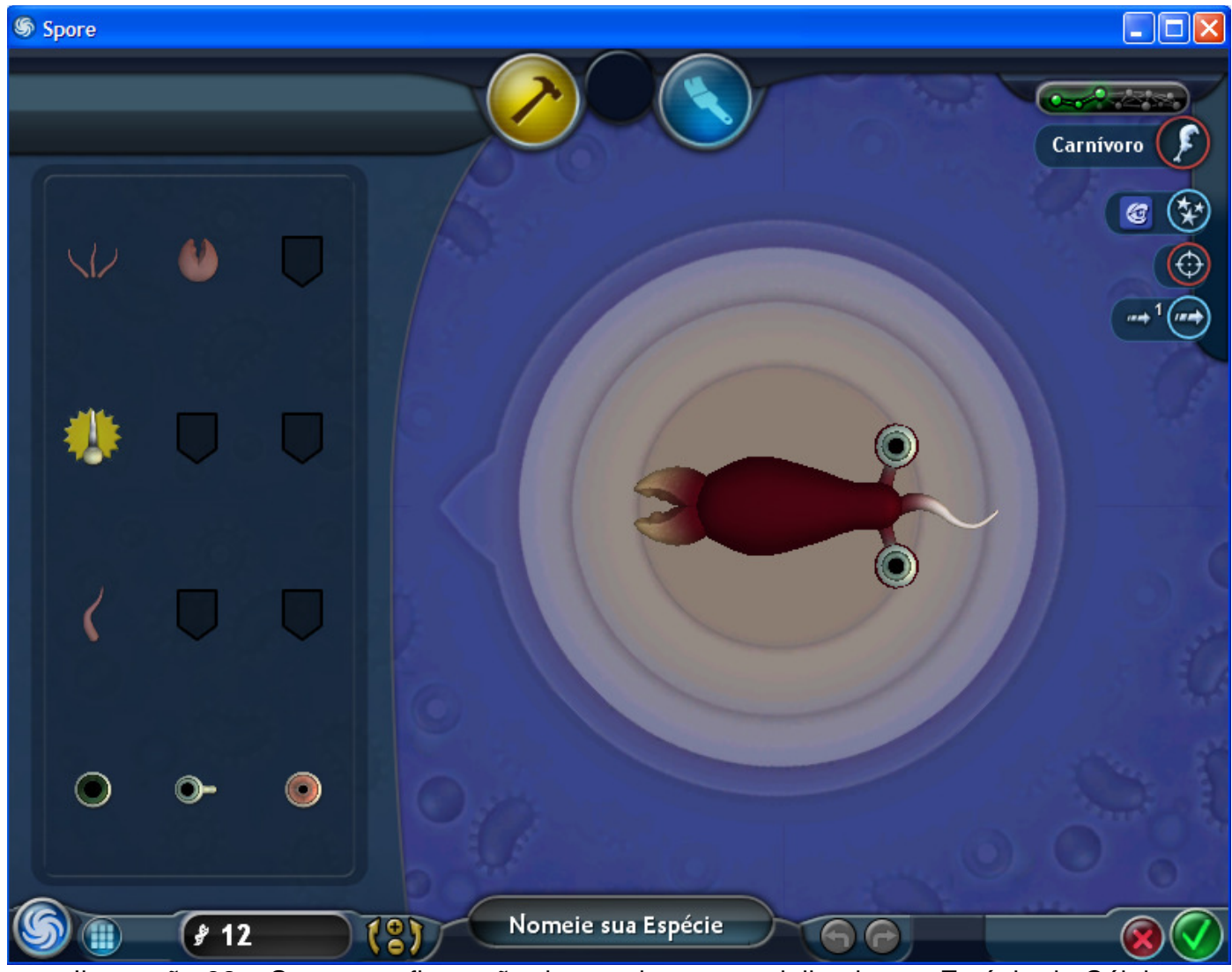

Ilustração 83 - Spore: configuração de membros especializados no Estágio de Célula Fonte: Produção própria (durante pesquisa exploratória do jogo) 
Para poder evoluir, a ameba deve coletar pontos de DNA (espécie de moeda genética adquirível indefinidamente) e traços genéticos específicos (que vão abrir novas possibilidades de membros especializados na janela de evolução), presentes nos seus alimentos. Existe uma barra de progresso que indica a fase evolutiva da ameba caracterizado principalmente pelos traços genéticos já encontrados. A ameba encontra concorrência e ameaças sendo obrigada a caçar ou fugir de outros seres.

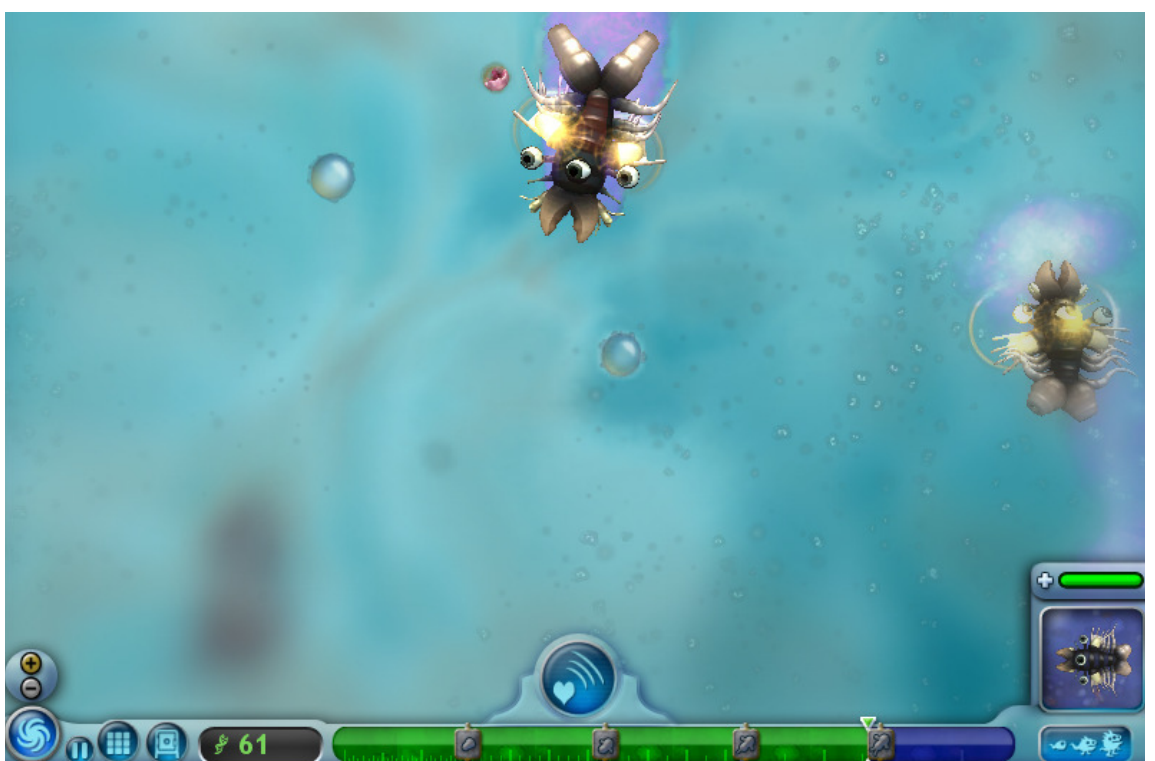

Ilustração 84 - Spore: interação com o meio controlando a ameba pelo mouse Fonte: Produção própria (durante pesquisa exploratória do jogo)

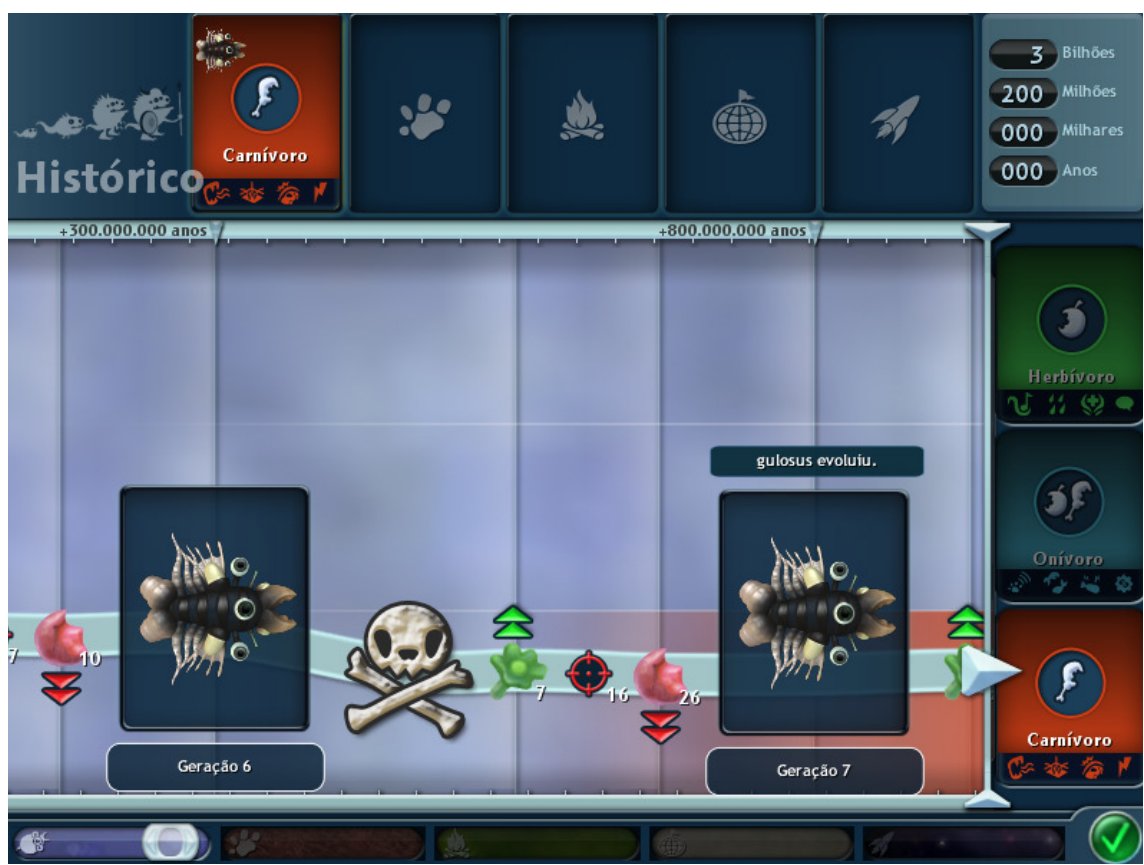

llustração 85 - Spore: tela do histórico evolutivo da ameba Fonte: Produção própria (durante pesquisa exploratória do jogo) 
Quando estiver evoluída, a ameba ganha pernas e novos membros para se adaptar à vida terrestre e, já no estágio de criatura vive em bando e interage com outras criaturas (caçando ou formando alianças simbióticas, dependendo das características já adotadas) com o objetivo de aumentar a sua capacidade cerebral. De fato, nessa fase, o progresso é medido pelo aumento do cérebro conforme a criatura vai adquirindo pontos de DNA e traços genéticos que vão conferindo maior capacidade intelectual para a formação de uma criatura seja com características predadoras ou seja com características sociais.

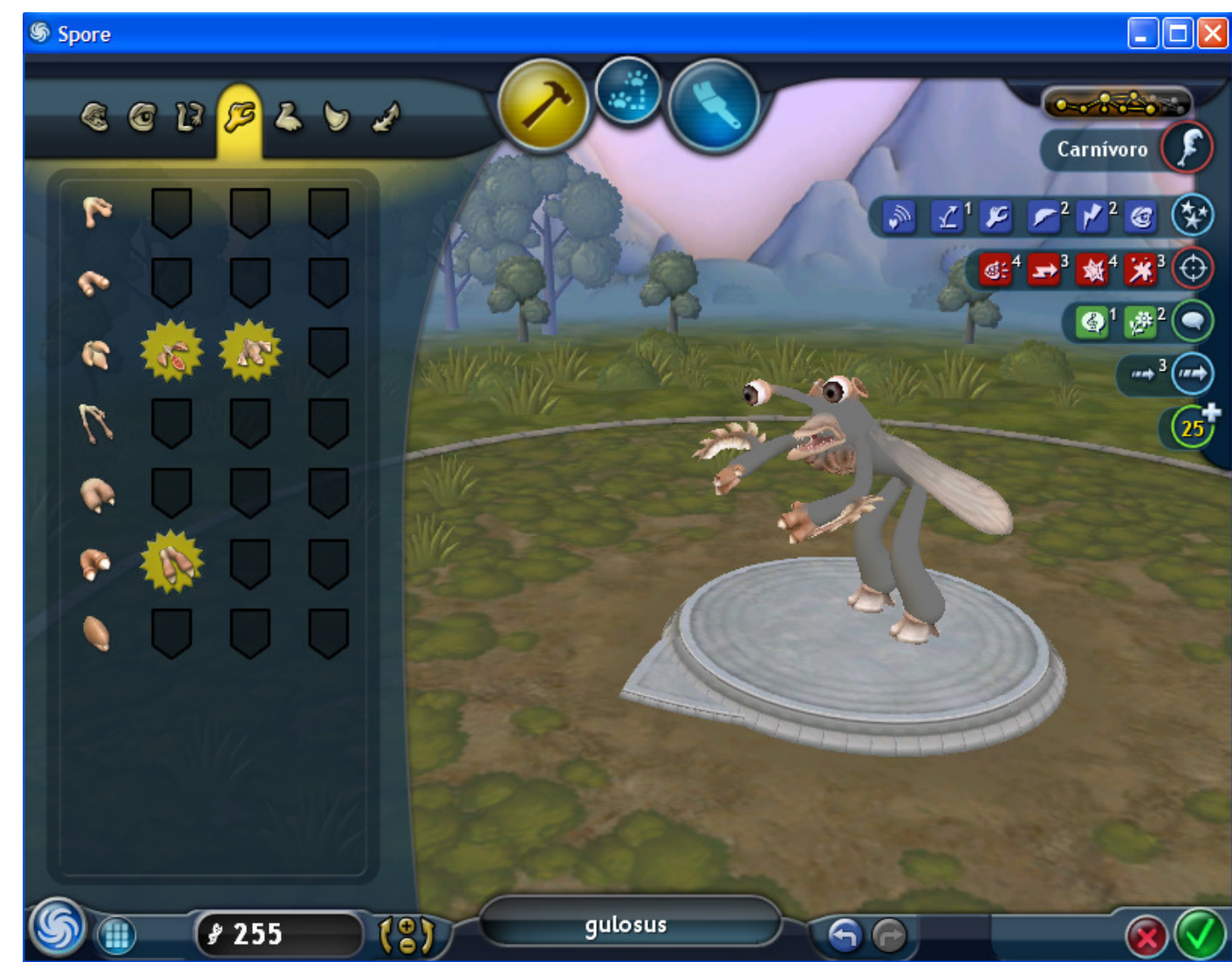

Ilustração 86 - Spore: tela de evolução da ameba/ criatura Fonte: Produção própria (durante pesquisa exploratória do jogo)

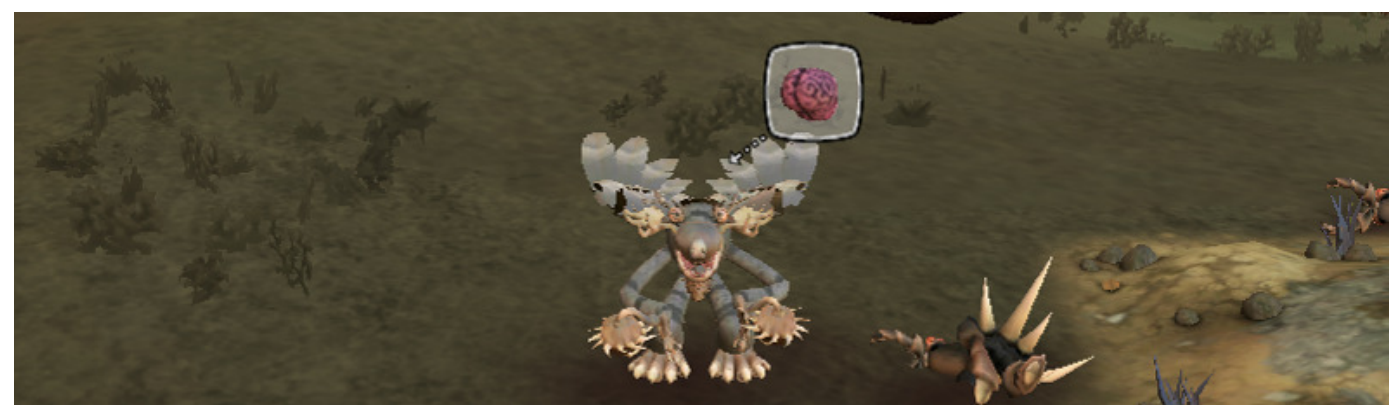

Ilustração 87 - Spore: desenvolvimento cerebral conforme o progresso da criatura Fonte: Produção própria (durante pesquisa exploratória do jogo) 
A interação social com outras criaturas ocorre através da caça eficiente (conforme os membros especializados conquistados) ou de aproximações sociais de aliança que podem ser firmadas através da boa impressão causada por danças, canção e poses em correspondência aos atos das demais criaturas (ações também possibilitadas por membros especializados).

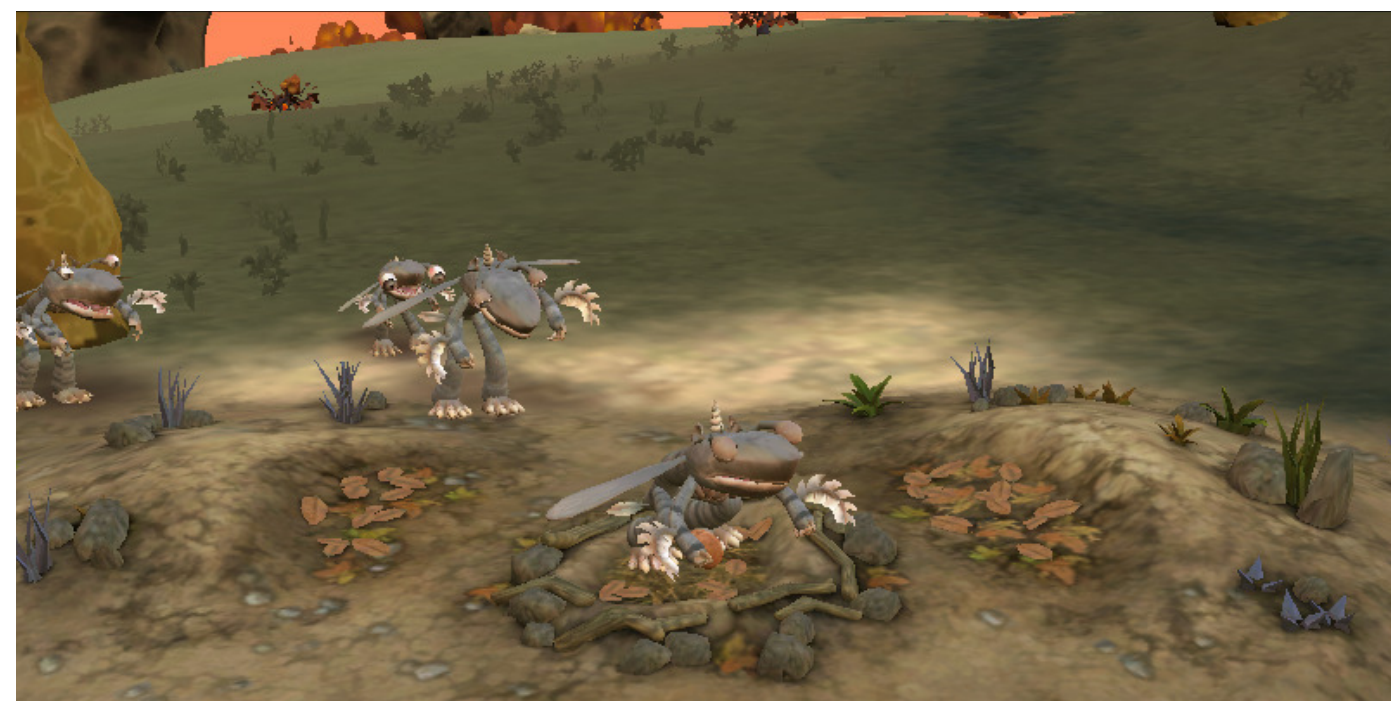

Ilustração 88 - Spore: interação com outras criaturas do bando Fonte: Produção própria (durante pesquisa exploratória do jogo)

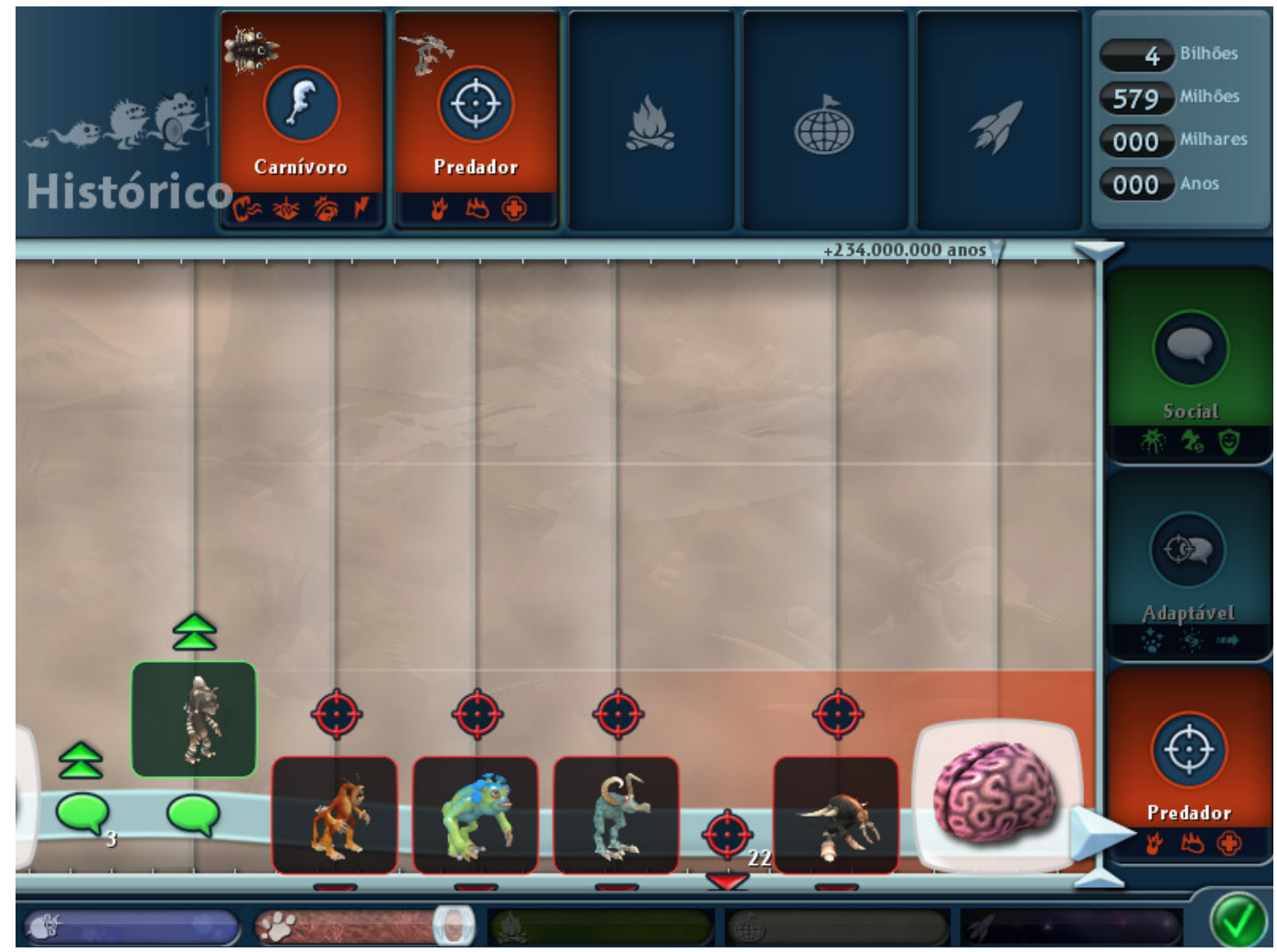

Ilustração 89 - Spore: tela de evolução da criatura

Fonte: Produção própria (durante pesquisa exploratória do jogo) 


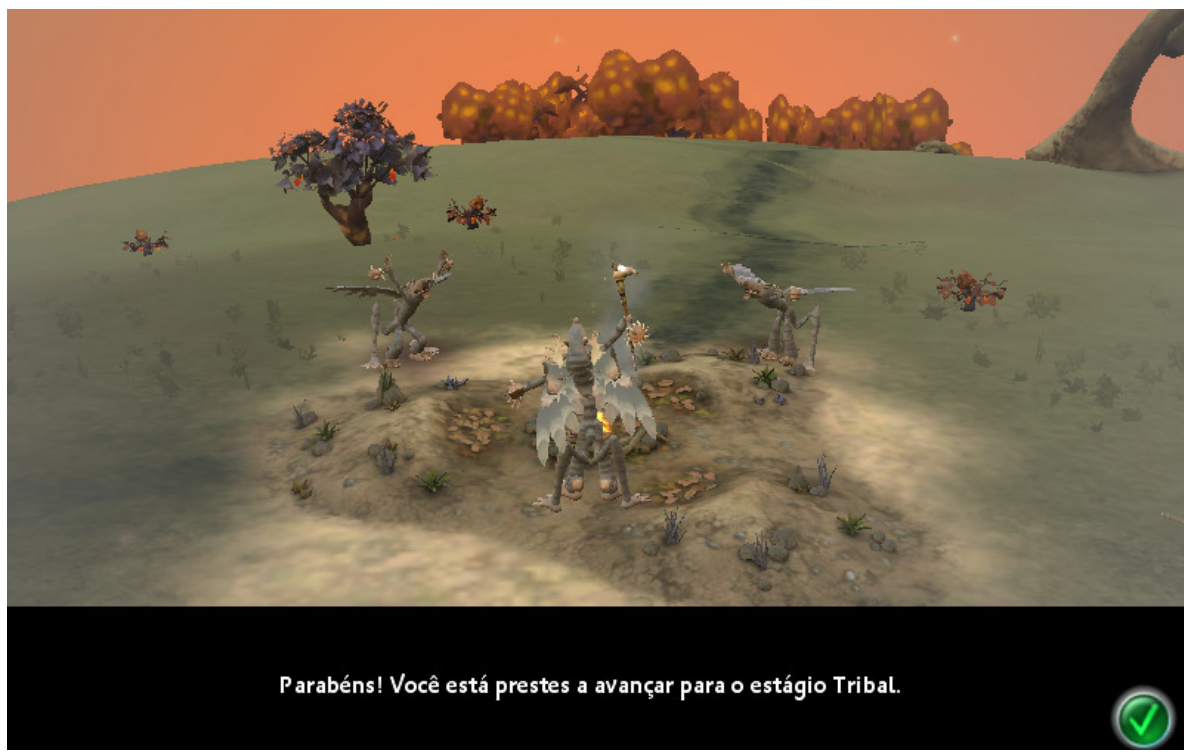

Ilustração 90 - Spore: tela de evolução da criatura

Fonte: Produção própria (durante pesquisa exploratória do jogo)

Com o cérebro desenvolvido e com o bando amadurecido nesse meio competitivo, as criaturas percebem que a melhor organização do bando em tribo vai garantir melhores condições de sobrevivência e inaugura o estágio tribal do jogo, onde não existe mais o desenvolvimento físico e genético da criatura, mas do seu comportamento social e cultural.

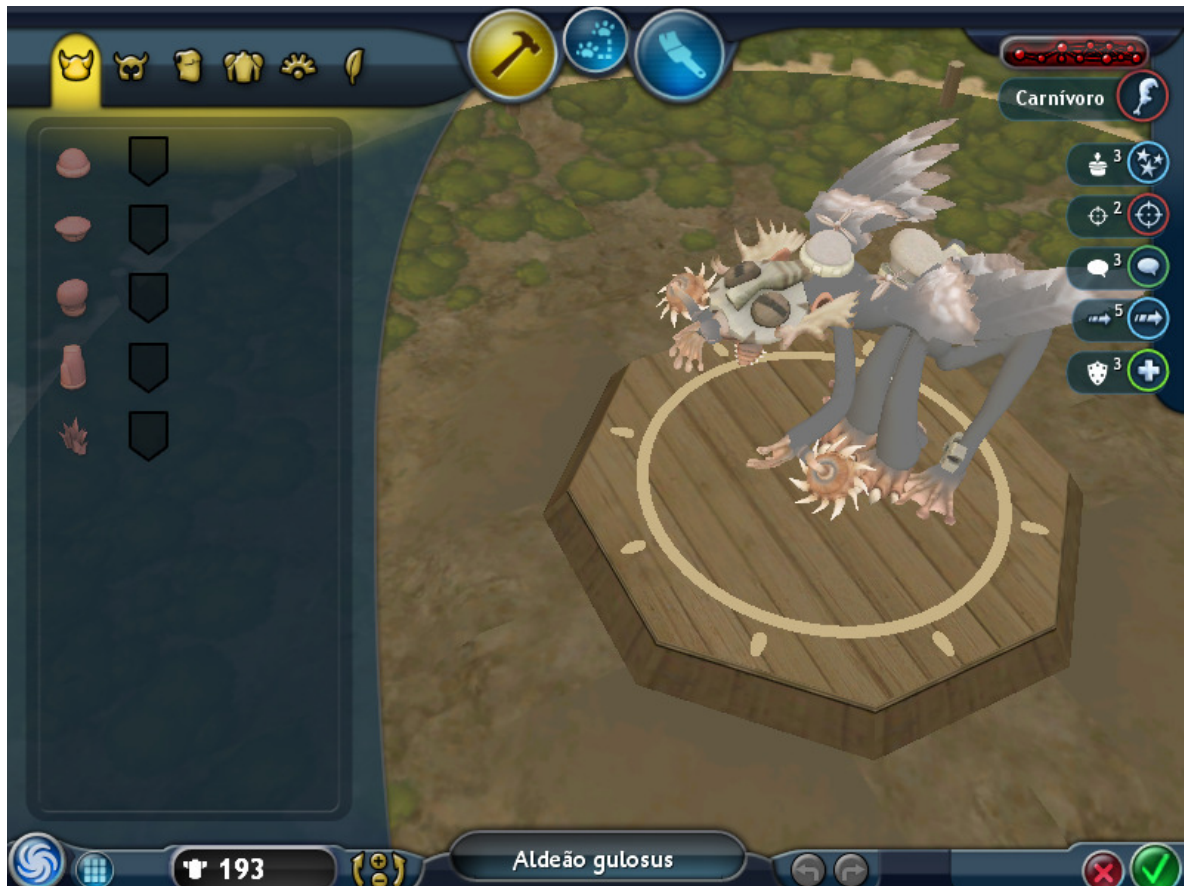

llustração 91 - Spore: tela de edição dos adornos dos aldeões no Estágio Tribal Fonte: Produção própria (durante pesquisa exploratória do jogo) 
Uma criatura do bando é eleita como o grande chefe que vai comandar a principal oca da tribo onde o jogador pode "encomendar" o nascimento de mais aldeões para a tribo crescer e ter, então, maior poder de coleta de alimentos, defesa e ataque a outras tribos.

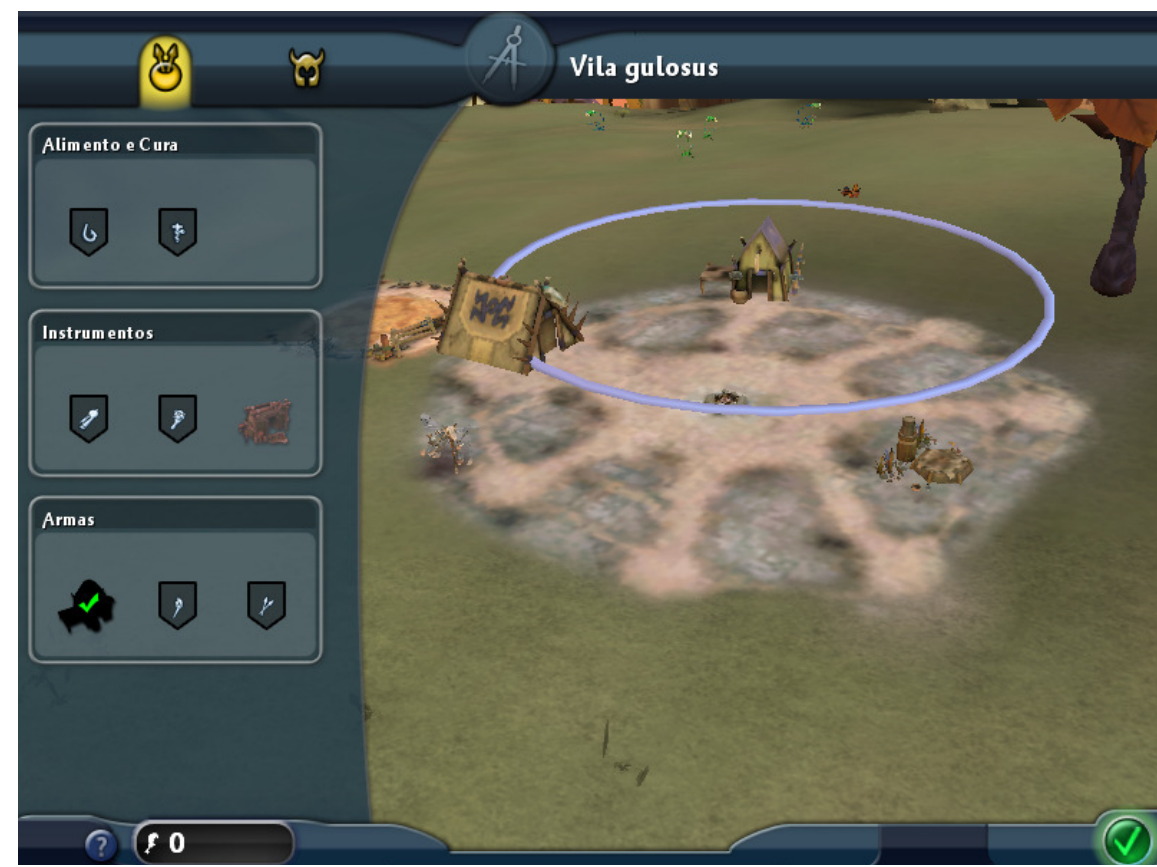

llustração 92 - Spore: tela de composição da aldeia no Estágio Tribal Fonte: Produção própria (durante pesquisa exploratória do jogo)

O grande chefe também é responsável por fazer contatos sociais com outras tribos caso exista o interesse em formar alianças e tratados de paz. A cada tribo conquistada (exterminada ou aliada) traz prosperidade para a tribo do jogador que pode, então, se expandir em números de membros e desenvolver novas tecnologias (pesca, construção de armas, etc.) e que vai determinando o progresso da fase.
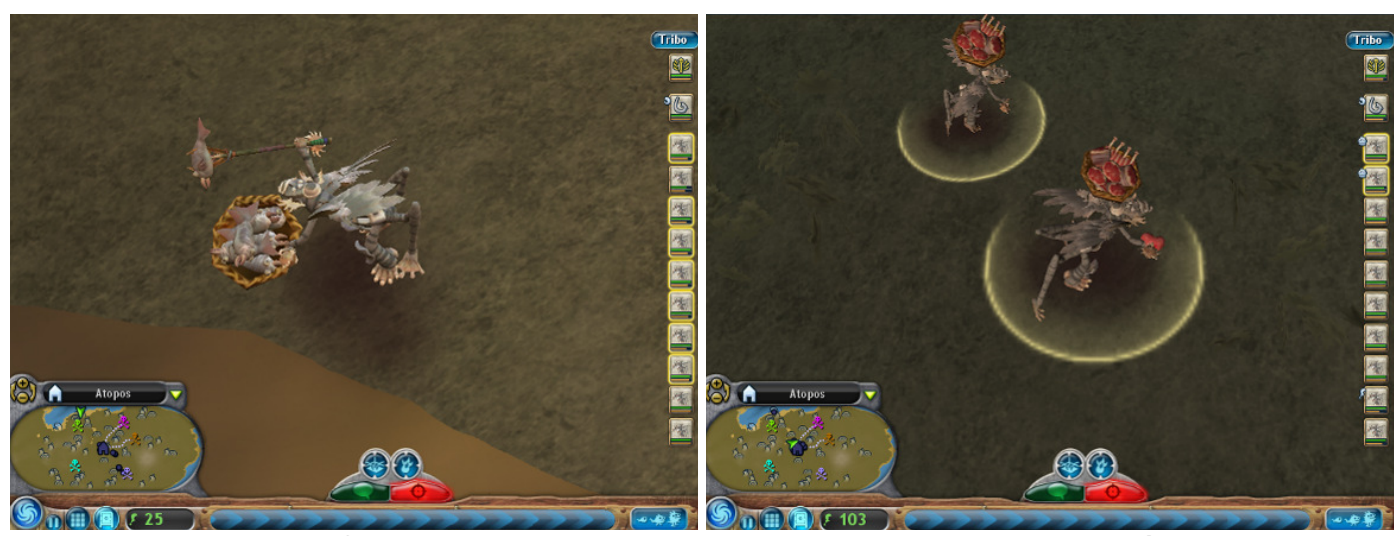

Ilustração 93 - Spore: aldeões especializados em pesca e caça no Estágio Tribal Fonte: Produção própria (durante pesquisa exploratória do jogo) 


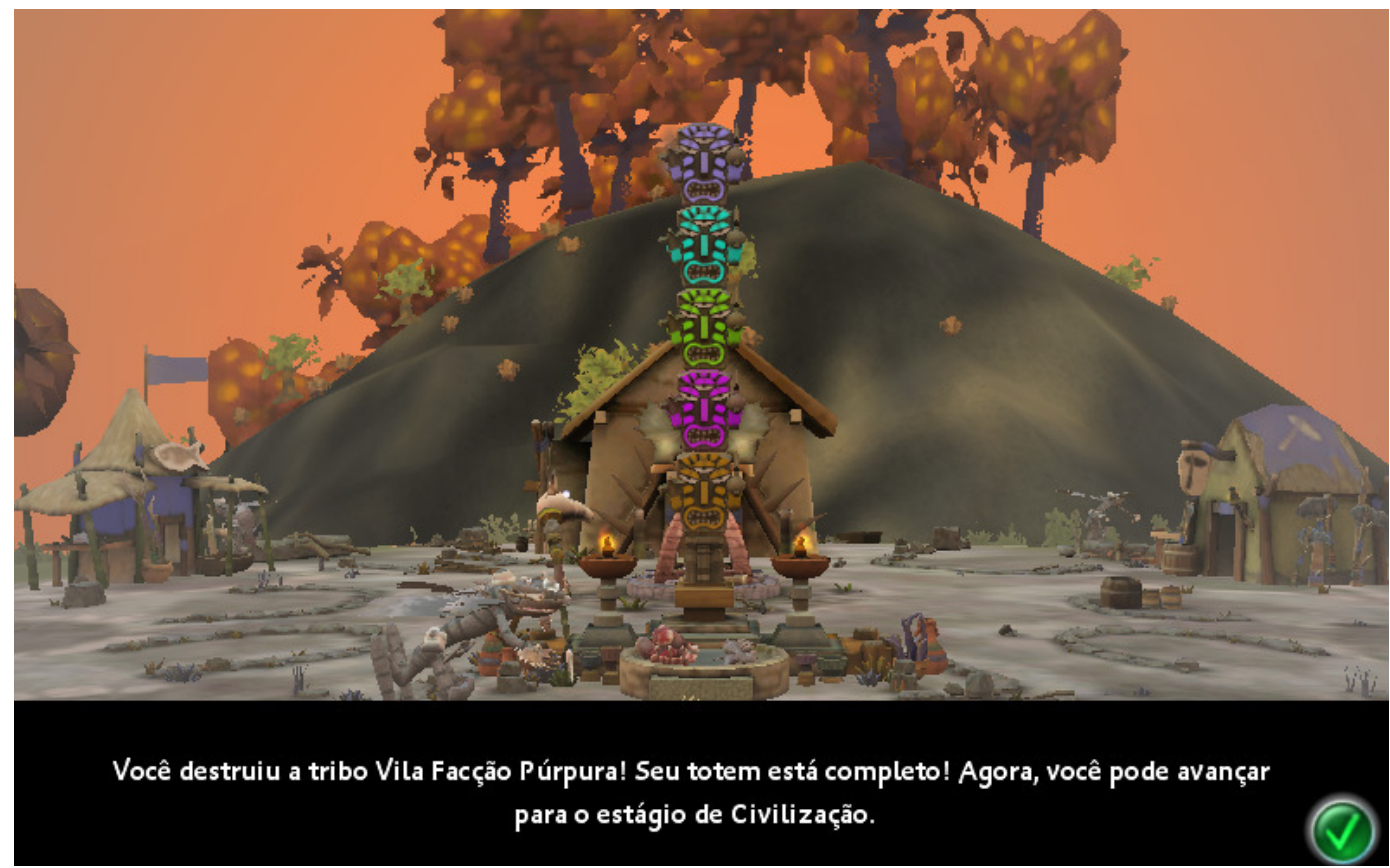

Ilustração 94 - Spore: tela de conquista de todas as tribos e fim do Estágio Tribal Fonte: Produção própria (durante pesquisa exploratória do jogo)

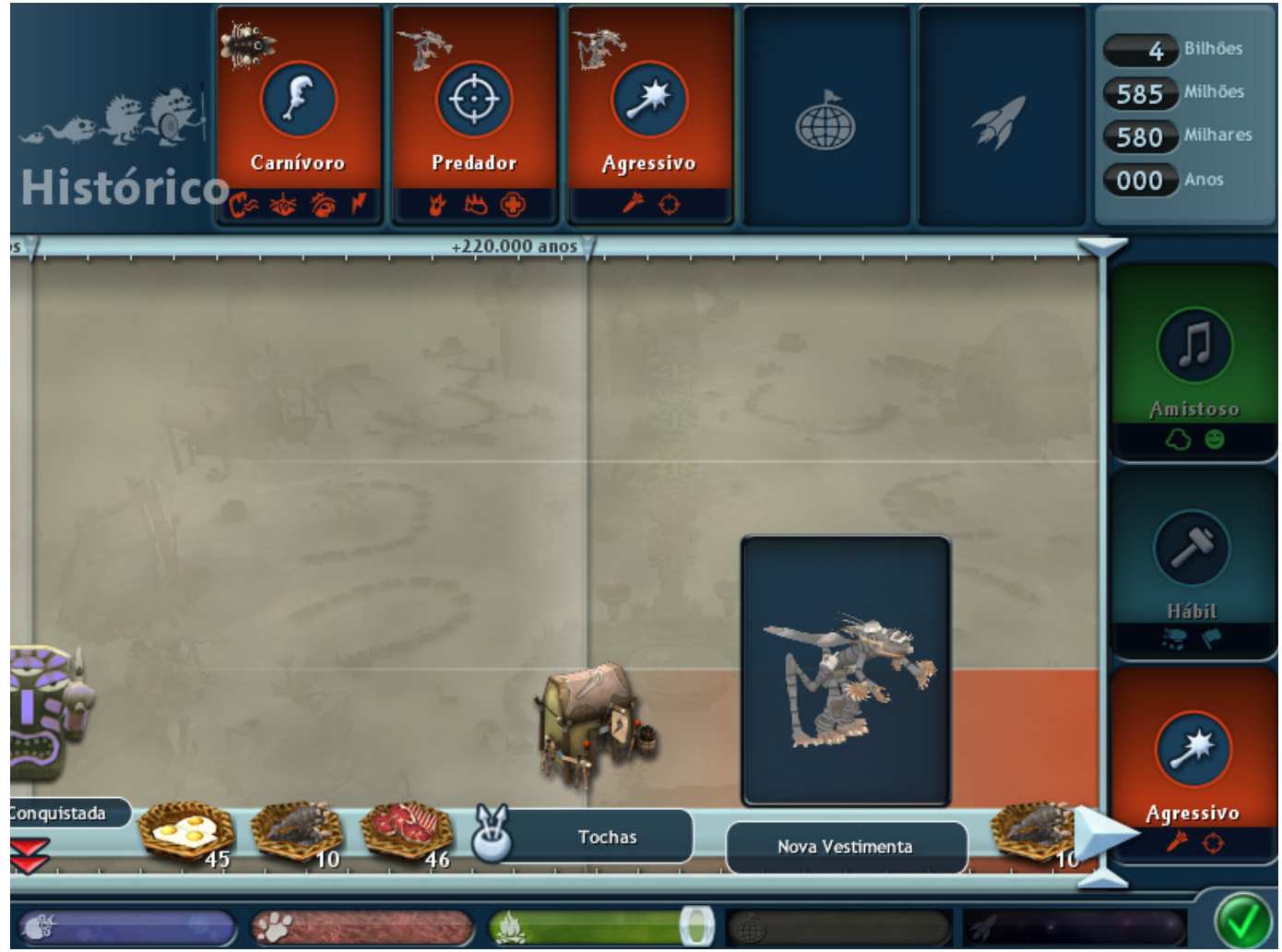

llustração 95 - Spore: tela de evolução da tribo

Fonte: Produção própria (durante pesquisa exploratória do jogo)

Após conquistar várias tribos, os seus membros exigem melhor organização social e melhores condições tecnológicas para a sobrevivência e o jogador passa a 
desenvolver cidades tendo, inclusive que desenvolver meios de transporte e construções como fábricas, casas e edifícios de entretenimento para aumentar o seu poder e conquistar outras civilizações do planeta, seja pela guerra, pelos tratados econômicos ou pela influência religiosa.

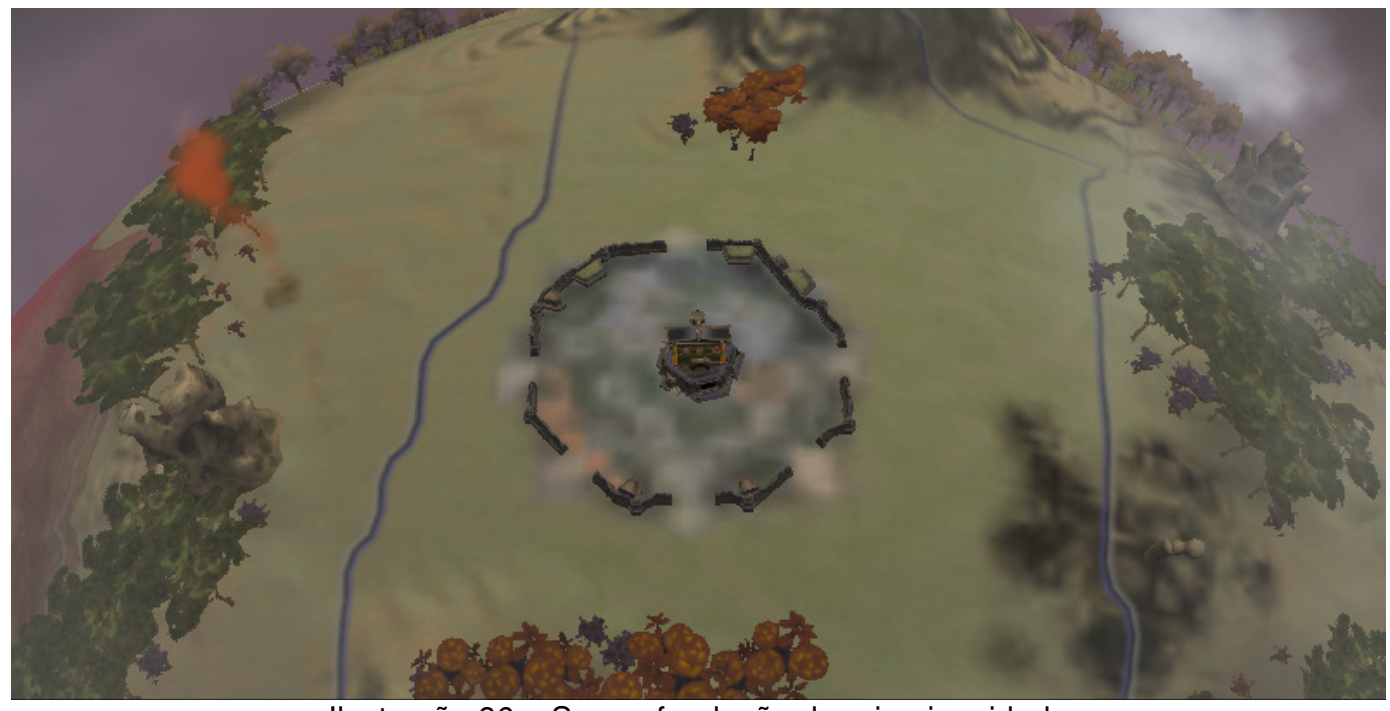

Ilustração 96 - Spore: fundação da primeira cidade

Fonte: Produção própria (durante pesquisa exploratória do jogo)

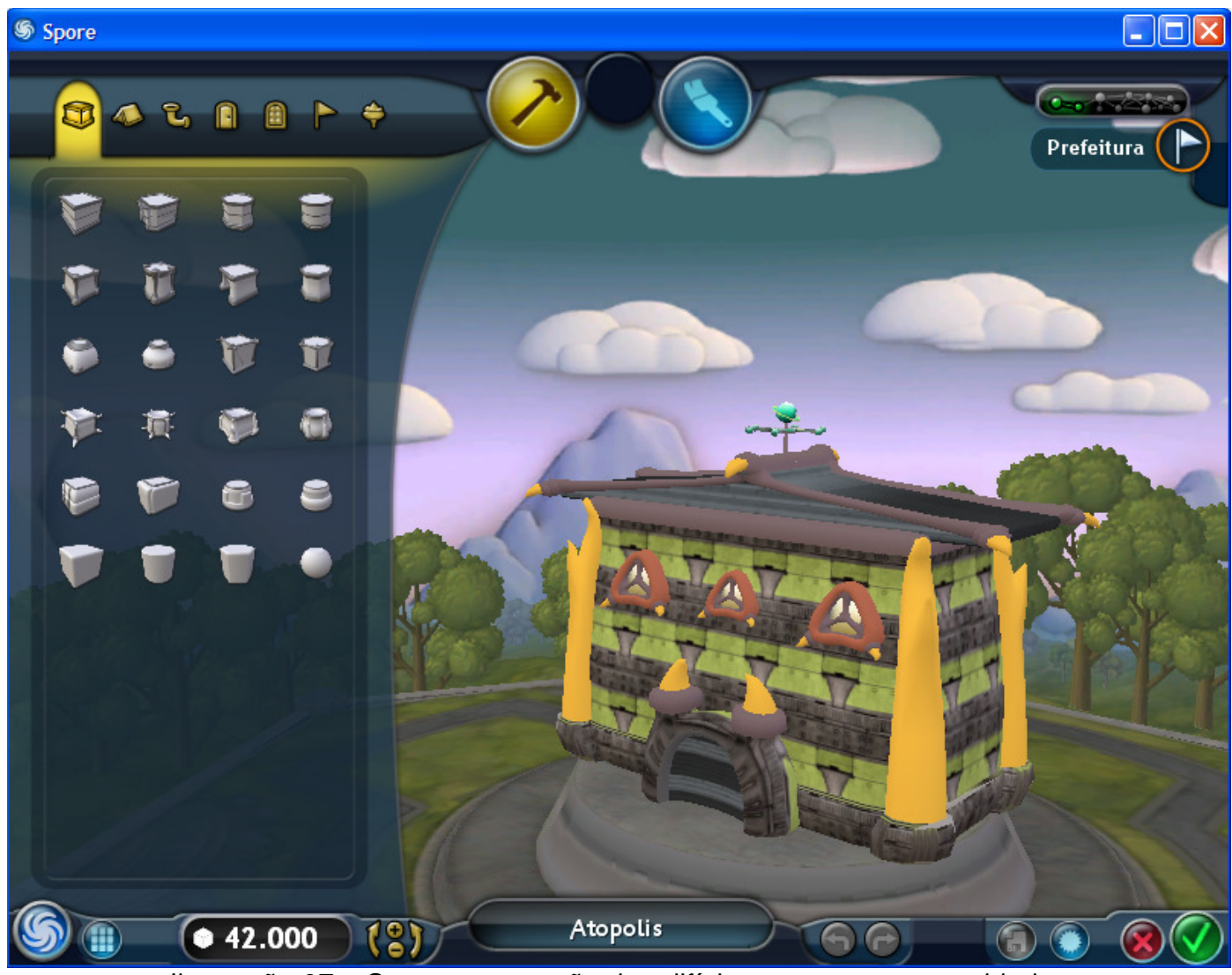

Ilustração 97 - Spore: construção de edifícios para compor as cidades

Fonte: Produção própria (durante pesquisa exploratória do jogo) 

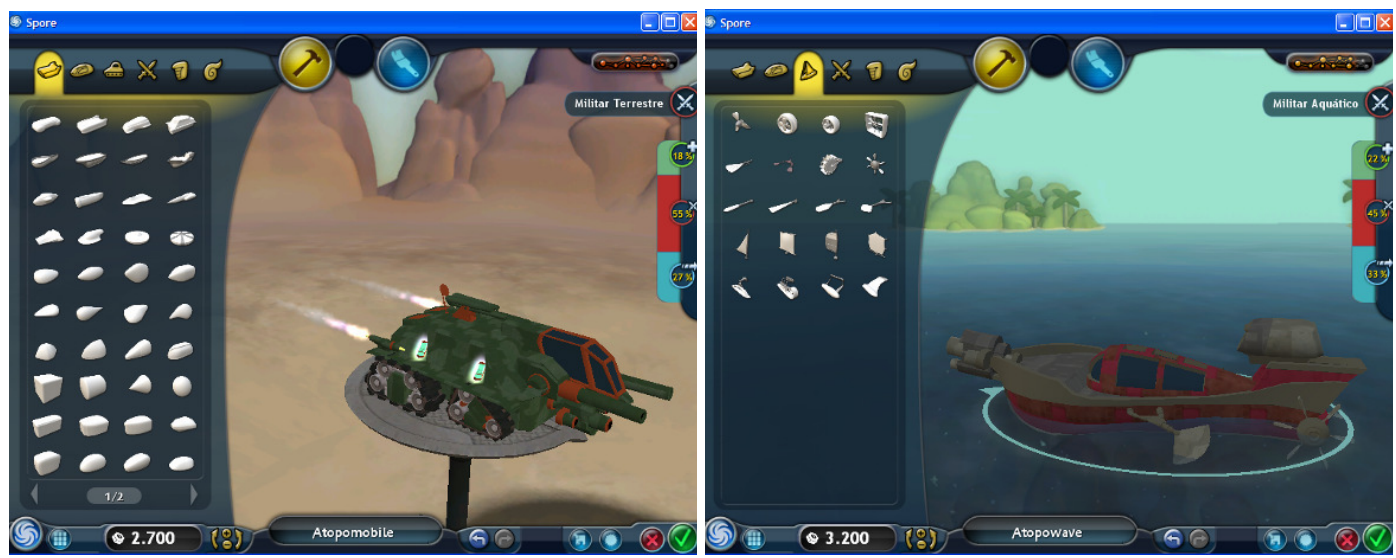

llustração 98 - Spore: construção de meios de transporte para conquistar o planeta

Fonte: Produção própria (durante pesquisa exploratória do jogo)

O jogador deve encontrar fontes de especiarias para ter poder aquisitivo, dinheiro e influência e assim poder construir. $O$ crescimento das cidades desenvolvidas e conquistadas se dá pela construção de defesa, casas, fábricas e entretenimento e determinará o número máximo de automóveis, navios e aviões que o império pode sustentar.

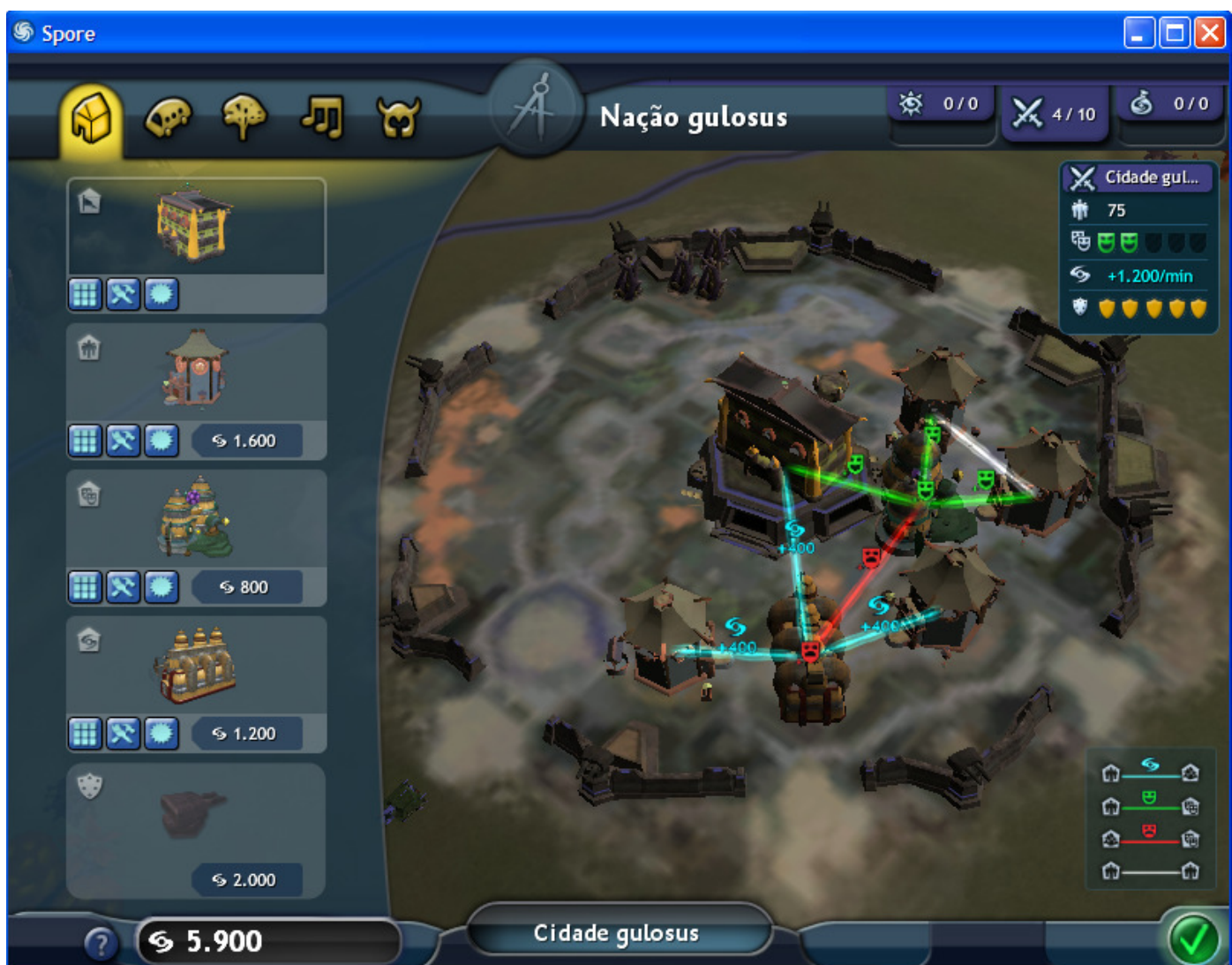

llustração 99 - Spore: composição das cidades com prefeitura, sistema de defesa, casas, fábricas e edifícios de entretenimento

Fonte: Produção própria (durante pesquisa exploratória do jogo) 


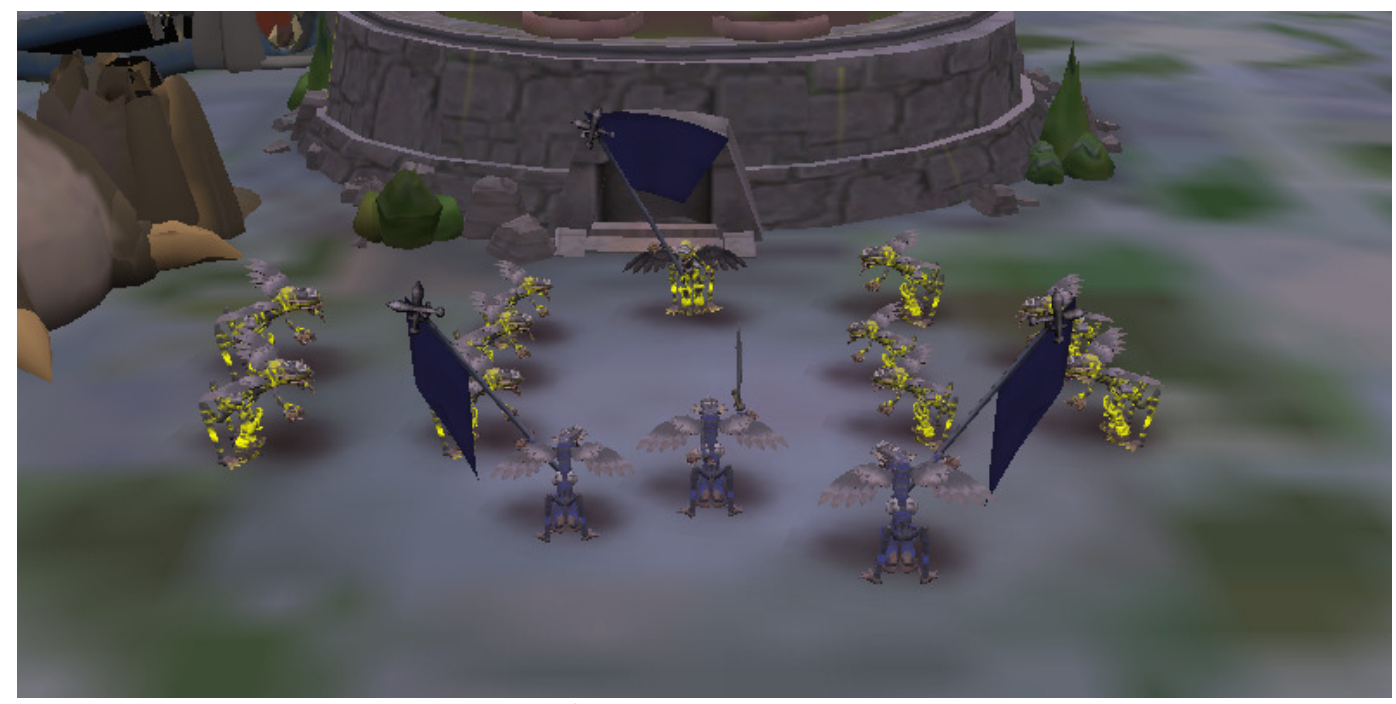

Ilustração 100 - Spore: conquista de uma civilização

Fonte: Produção própria (durante pesquisa exploratória do jogo)

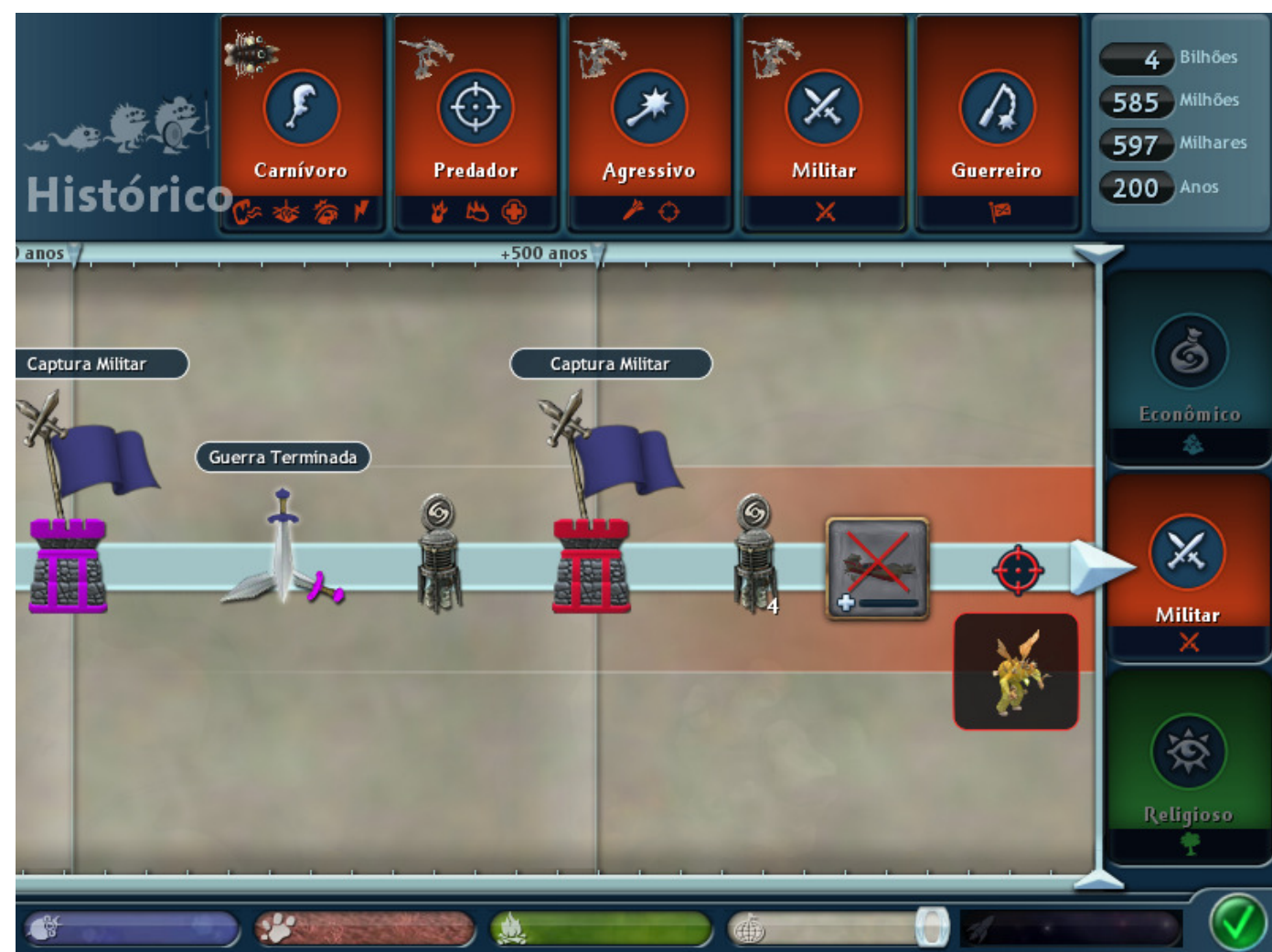

Ilustração 101 - Spore: tela de evolução da civilização

Fonte: Produção própria (durante pesquisa exploratória do jogo)

Com a conquista de todas as civilizações e, portanto, domínio sobre o planeta, o jogador alcança a tecnologia espacial e ruma para outros planetas, sistemas e galáxias buscando instalar colônias em diversos planetas com diferentes especiarias e firmar alianças e guerras com outros impérios galácticos para se expandir. 


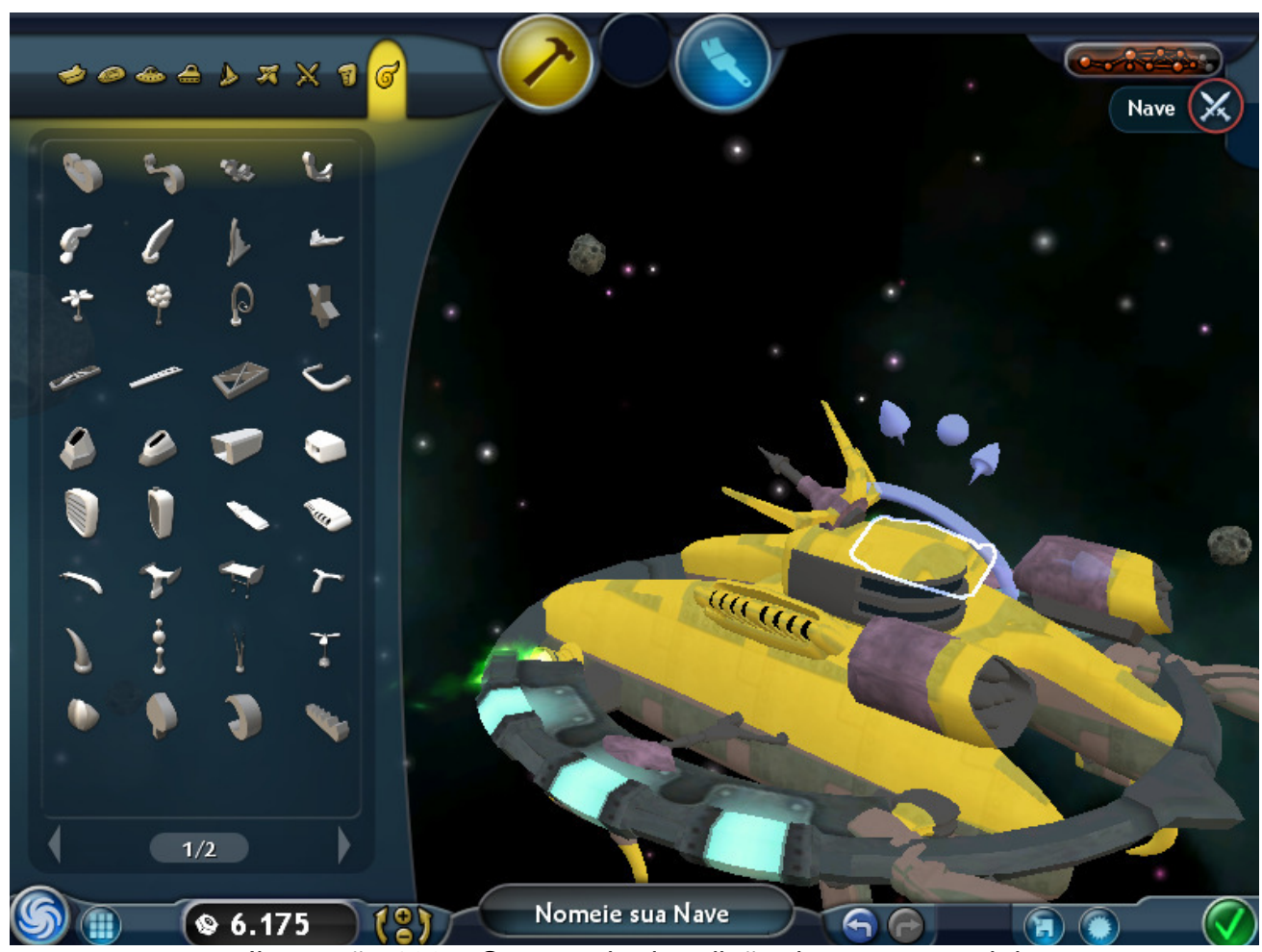

Ilustração 102 - Spore: tela de edição da nave espacial

Fonte: Produção própria (durante pesquisa exploratória do jogo)

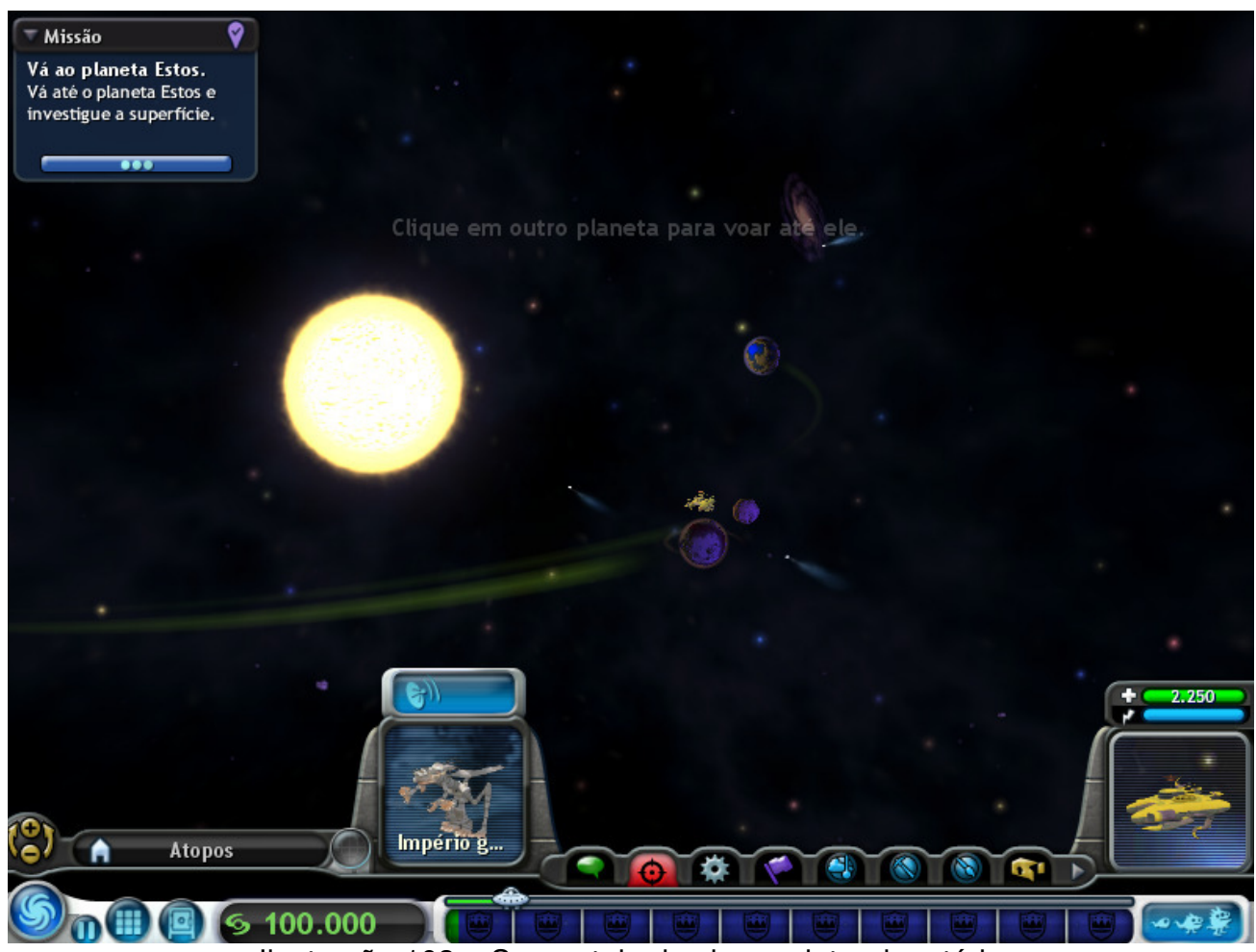

llustração 103 - Spore: tela de viagem interplanetária

Fonte: Produção própria (durante pesquisa exploratória do jogo) 
Várias missões são adicionadas e são cumpridas em conjunto ao longo dessa última fase que, apesar de ter uma linha de progresso, pode ser jogada infinitamente, se o jogador assim quiser, na interação com infinitos planetas desenvolvidos por outros jogadores e disponibilizados para o compartilhamento na biblioteca do Spore, a Sporepedia.

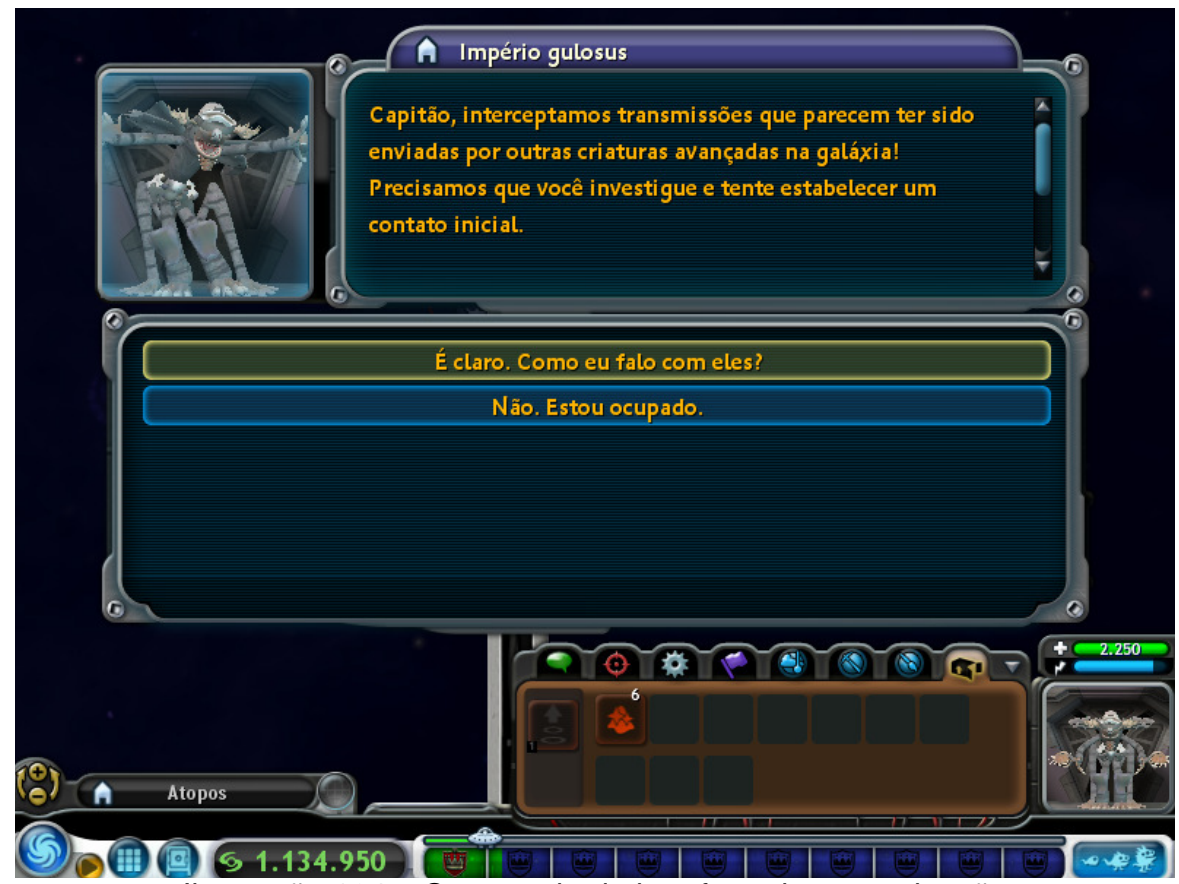

Ilustração 104 - Spore: tela de interface de comunicação

Fonte: Produção própria (durante pesquisa exploratória do jogo)

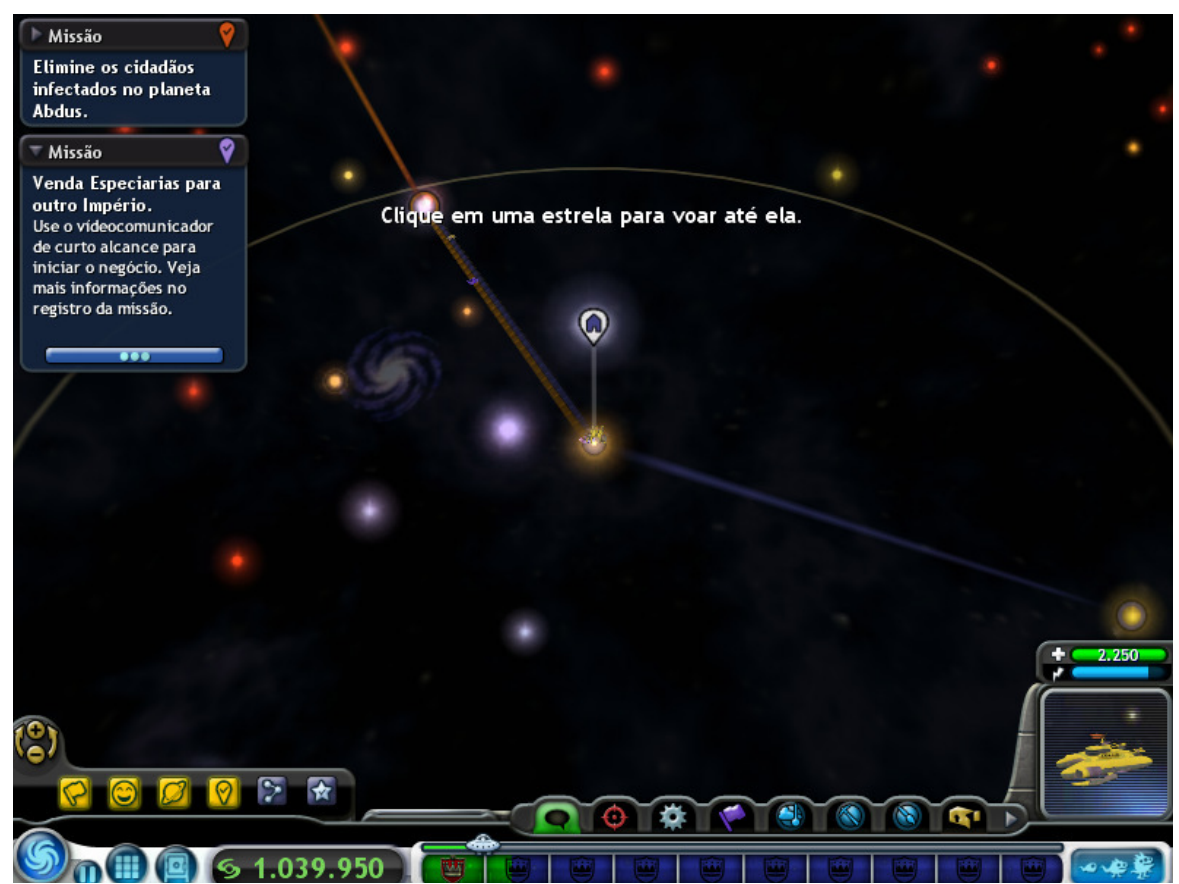

llustração 105 - Spore: viagens espaciais e admissão de missões

Fonte: Produção própria (durante pesquisa exploratória do jogo) 

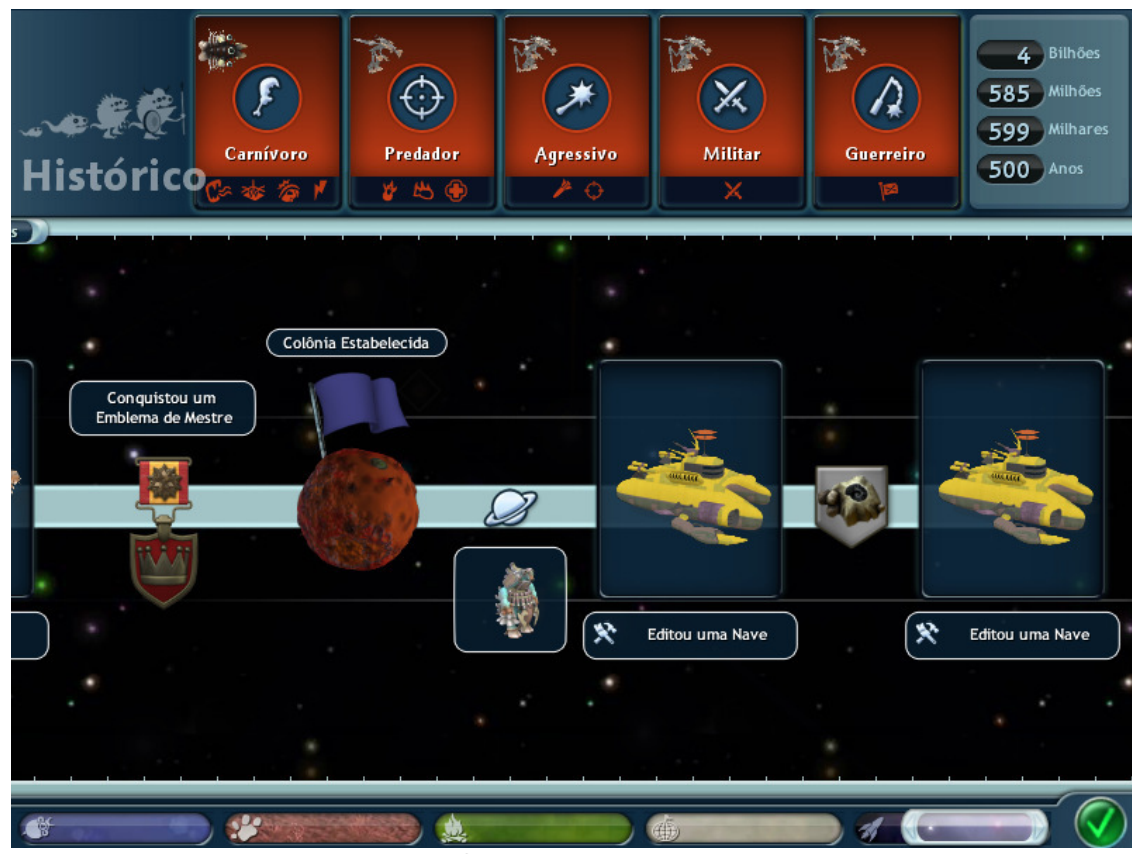

Ilustração 106 - Spore: tela da evolução espacial

Fonte: Produção própria (durante pesquisa exploratória do jogo)

\section{Reflexo e resposta}

Todos os estágios contam com a resposta e reflexo do jogador, sobretudo na interação com outras criaturas e civilizações, seja no tempo-resposta com o mouse e teclado para realizar atos de socialização, seja para fugir ou caçar. Por exemplo, o jogador deve sempre estar atento em relação à alimentação e em caso de perigo (como o surgimento de predadores).

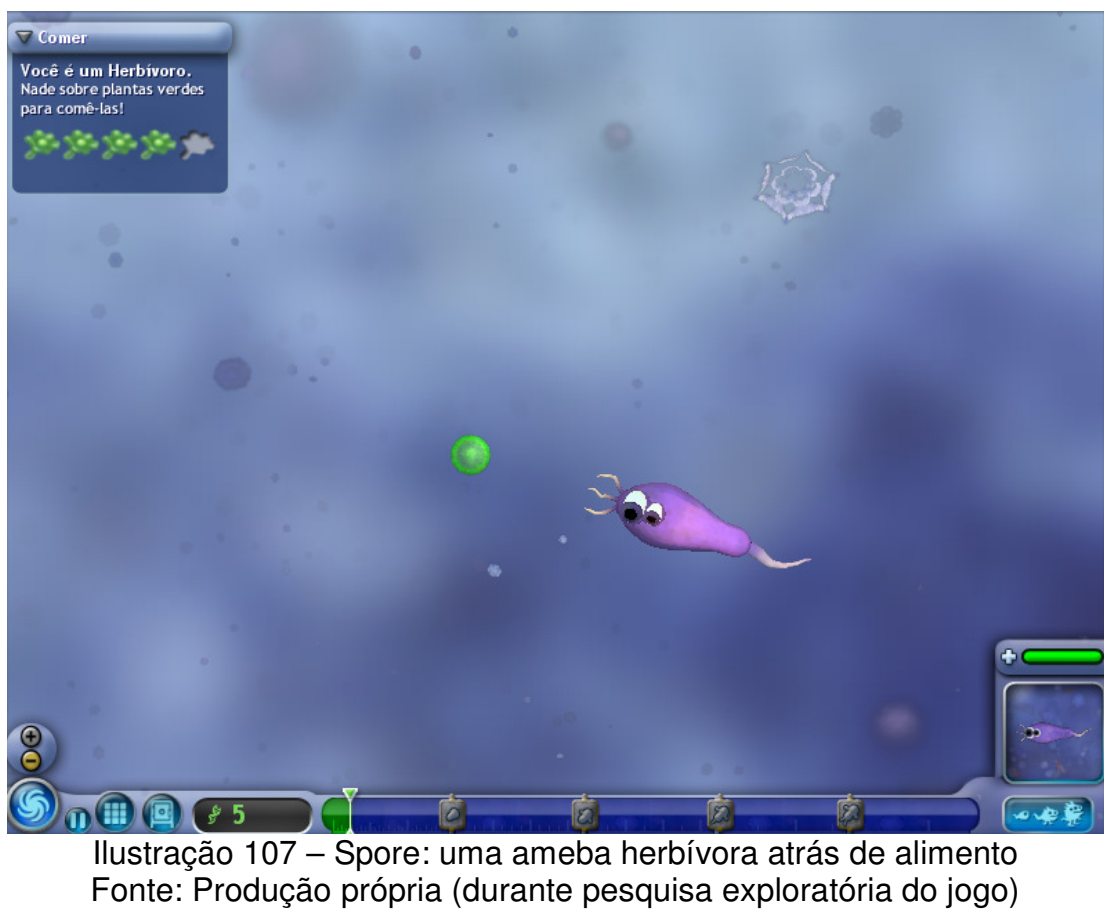




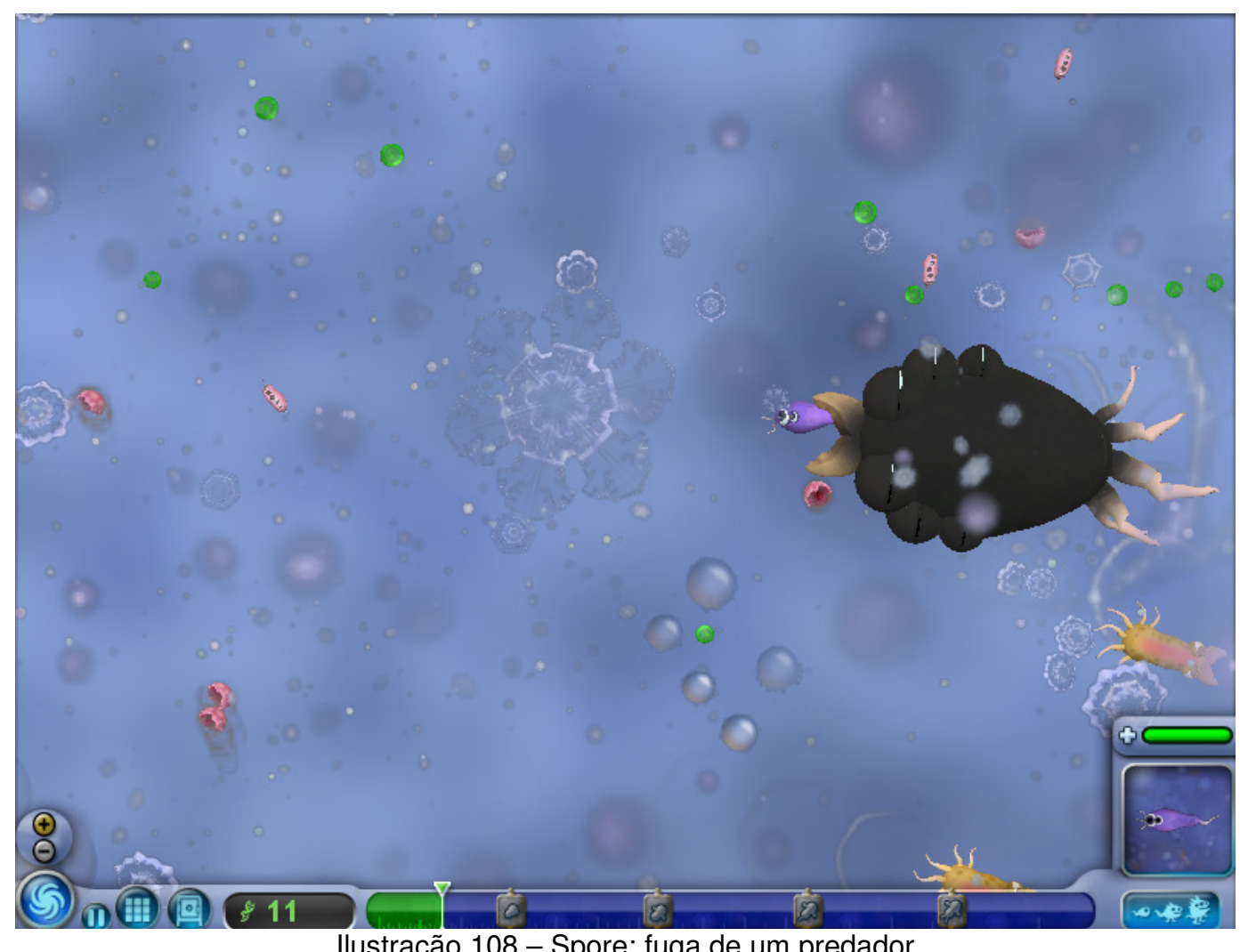

Fonte: Produção própria (durante pesquisa exploratória do jogo)

No estágio de criatura, o jogador deve continuamente fazer o ritual de corte para poder implementar os membros adquiridos durante o processo de evolução. Para tanto, deve retornar ao seu ninho e chamar o parceiro, estando atento para achar o parceiro correto. Assim, ocorre o encontro e o jogador entra na tela de criação da criatura.

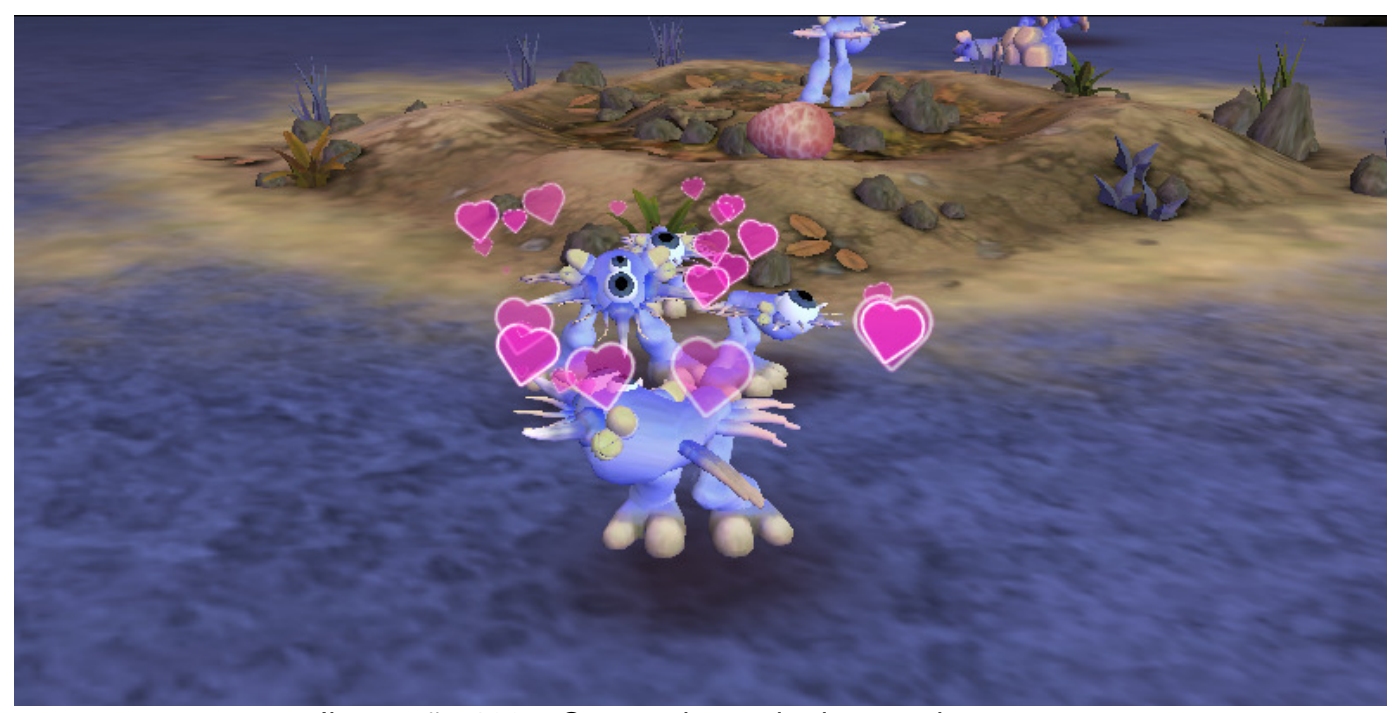

Ilustração 109 - Spore: chamado do parceiro e corte Fonte: Produção própria (durante pesquisa exploratória do jogo) 
Ainda no estágio de criatura, o jogador deve estabelecer alianças com outras raças e, se for o caso, se defender e atacar raças hostis. O controle por mouse e teclado (para definir o comando) se torna vital na resposta rápida exigida para a eficiência da ação.
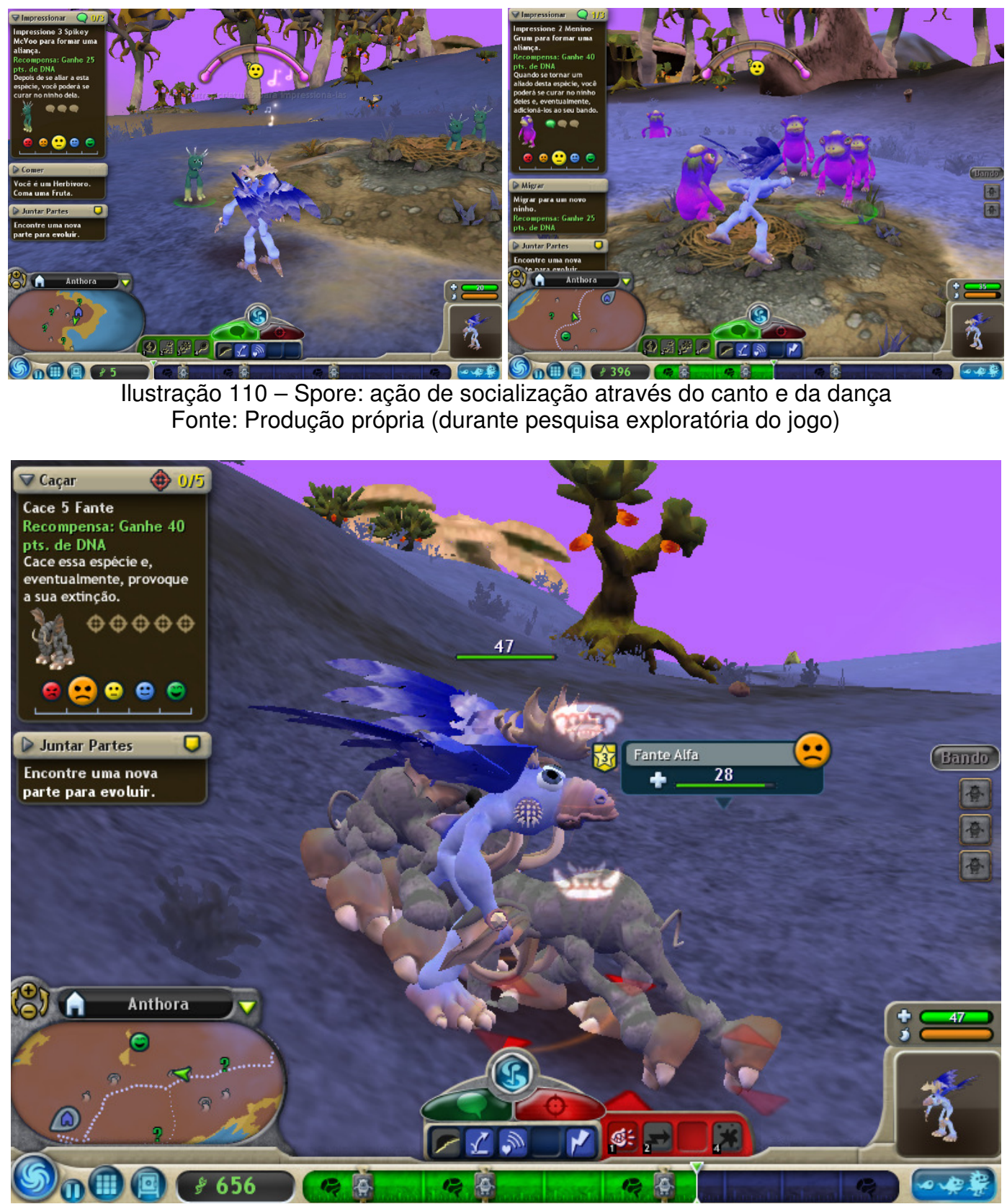

Ilustração 111 - Spore: ação de combate de defesa e ataque Fonte: Produção própria (durante pesquisa exploratória do jogo)

$\mathrm{Na}$ fase tribal o jogador tem o desafio de comandar os vários aldeões para diversas ações e atividades necessárias para a sobrevivência e expansão da tribo. A rápida escolha de aldeões se dá pela seleção múltipla pelo mouse e, também, pela 
lateral direita onde estão todos listados. A escolha de comando para os aldeões selecionados ocorre por clique de botão ou por comando de teclas. Para maior eficiência, seleção e comando devem ser operados rapidamente.

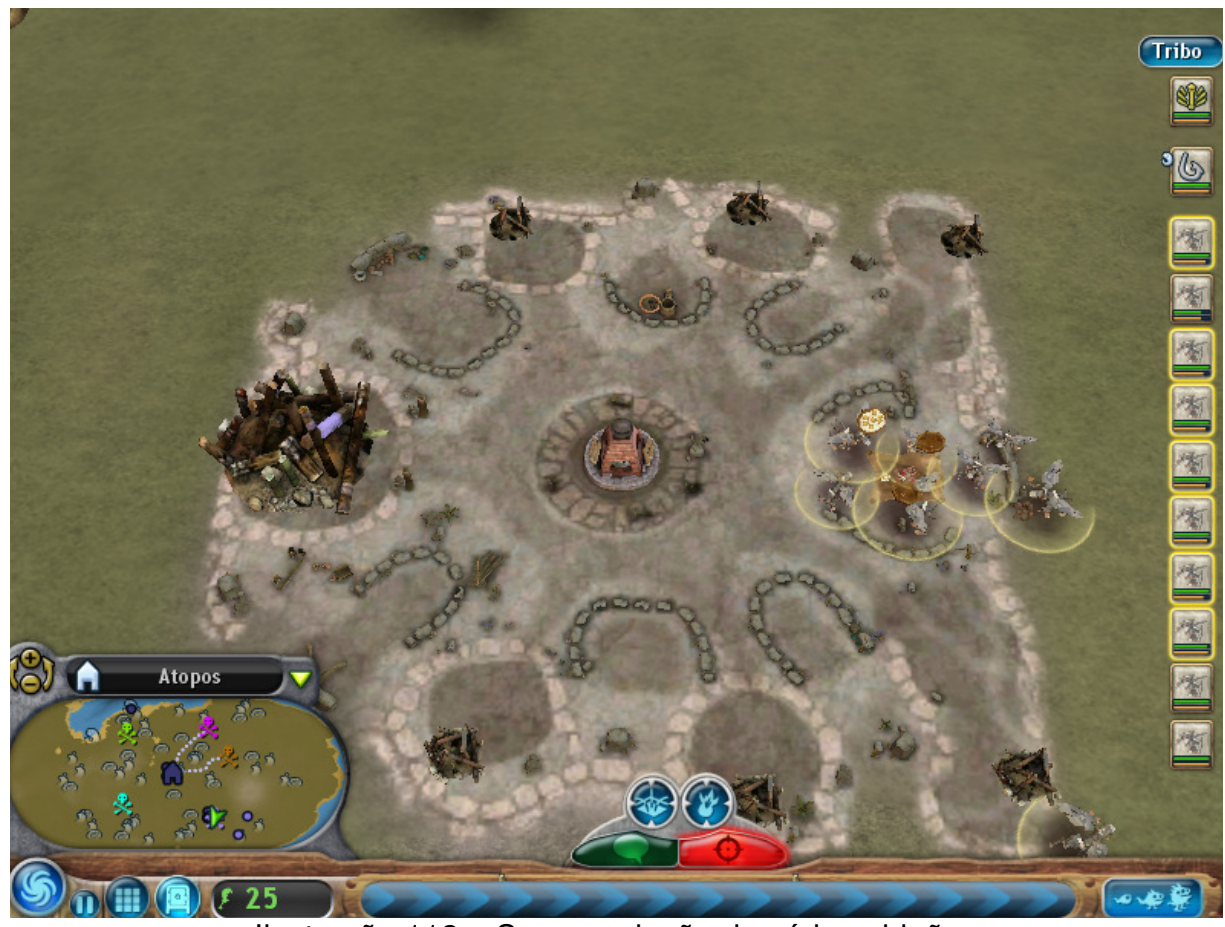

Ilustração 112 - Spore: seleção de vários aldeões

Fonte: Produção própria (durante pesquisa exploratória do jogo)

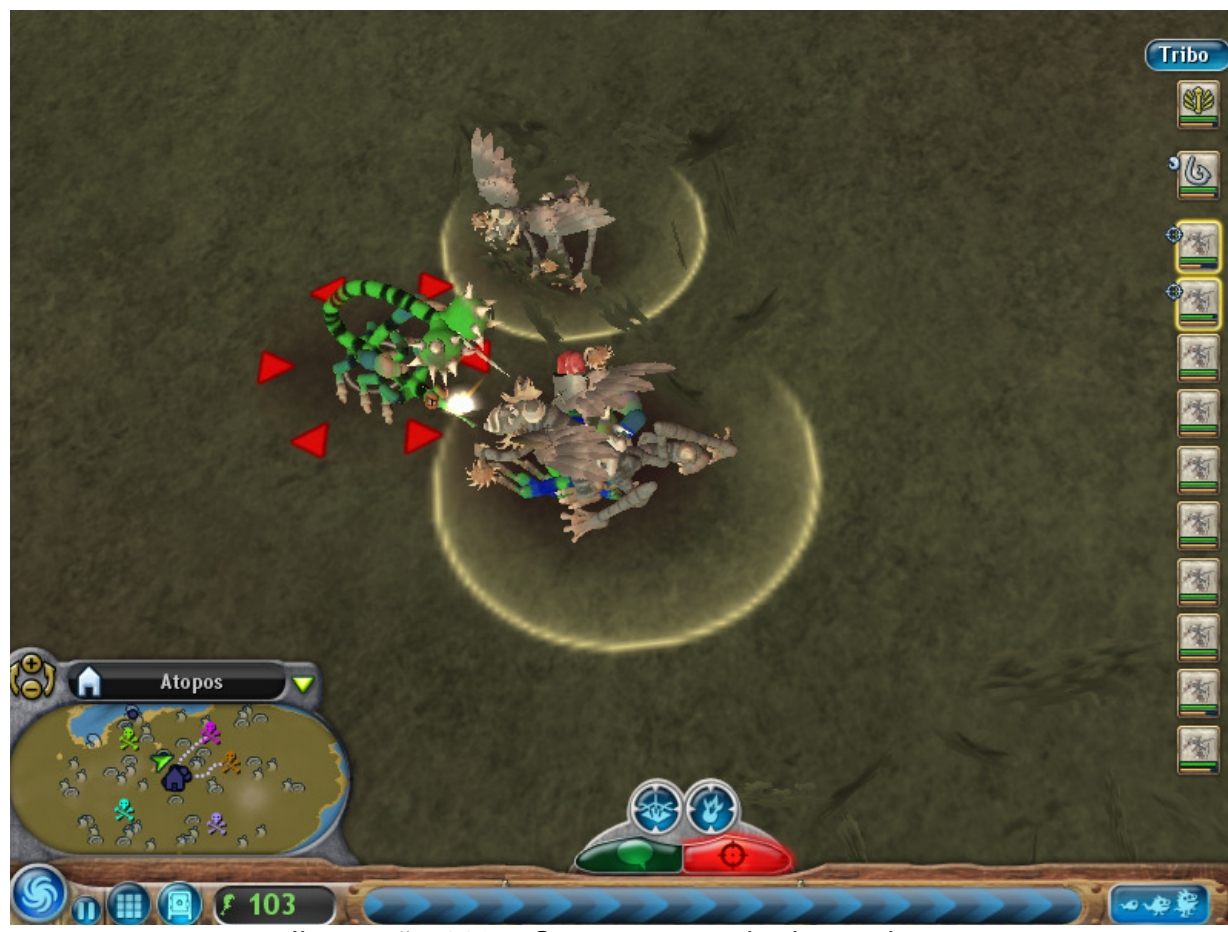

llustração 113 - Spore: comando de combate

Fonte: Produção própria (durante pesquisa exploratória do jogo) 
No estágio de civilização, o jogador não comanda mais pessoas, mas as cidades, prefeituras e os meios de transporte. Assim, deve comandar um tanque para guerra ou para extração de minérios, podendo fazer uma seleção múltipla pelo mouse ou pela lateral direita onde estão listados todos os meios de transporte. Aqui também existe a necessidade de se comandar com extrema velocidade para maior eficiência da ação.

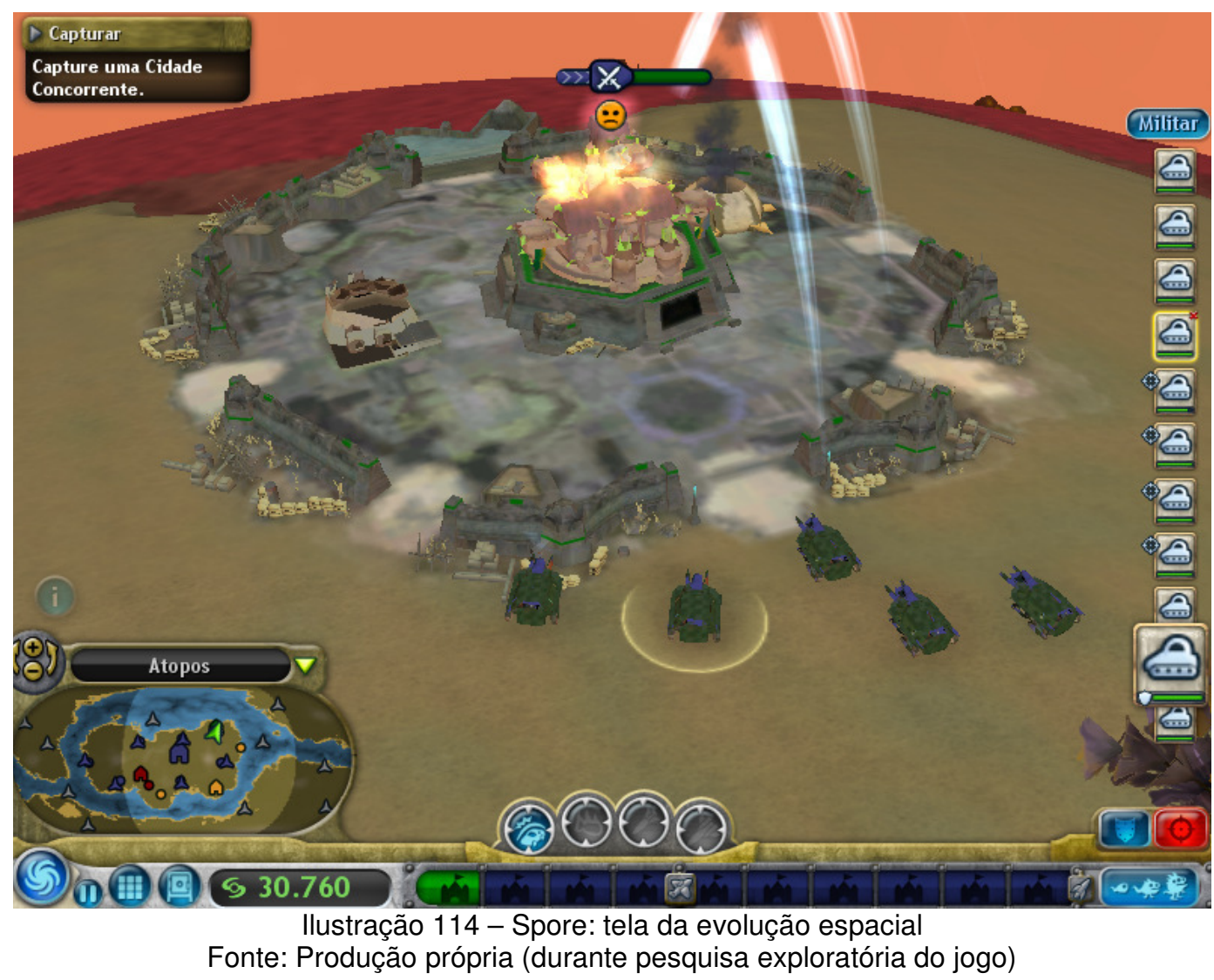

No estágio espacial existe maior atribuição estratégica que exige mais o raciocínio do que a resposta imediata às condições e acontecimentos. Portanto o jogador interage de forma menos veloz e com mais enfoque no desempenho do planejamento.

\section{Conteúdo informacional}

No Spore alguns predicados da ciência são ludicamente apresentados a fim de conduzir a narrativa da evolução de um ser vivo desde um planeta desabitado até a conquista espacial. Nos estágios de célula e de criatura, o jogo se baseia essencialmente no predicado contemporâneo do evolucionismo de Darwin, onde as 
espécies, passando por vários processos de mutação genética e seleção natural em resposta ao ecossistema, vão se especializando e apresentando membros específicos que melhoram o seu desempenho no meio. Assim, a evolução das espécies só acontece conforme o jogador vai definindo a linha de especialização da criatura criada. É claro que não existe um rigor científico absoluto sobre a narrativa, mesmo porque a evolução carrega as decisões, desejos e inteligência estratégica do jogador e não está ao acaso de milhões de anos, cross-over no DNA e mutações genéticas. De qualquer forma, existe a abertura para a curiosidade sobre a visão científica da evolução.

Outro fator didático ocorre sobre a formação de comunidades e sociedades durante os estágios de tribo e civilização quando o comportamento social do ser humano é explorado de forma literal nas atribuições de características que definem a sua forma de se relacionar com outros povos e nações. Dessa forma, é trabalhado o caráter de agressividade, amigabilidade e habilidade social em paralelo com a formação de nações militares, econômicas ou religiosas, explorando como a organização social influencia nas possibilidades de ação socializante.

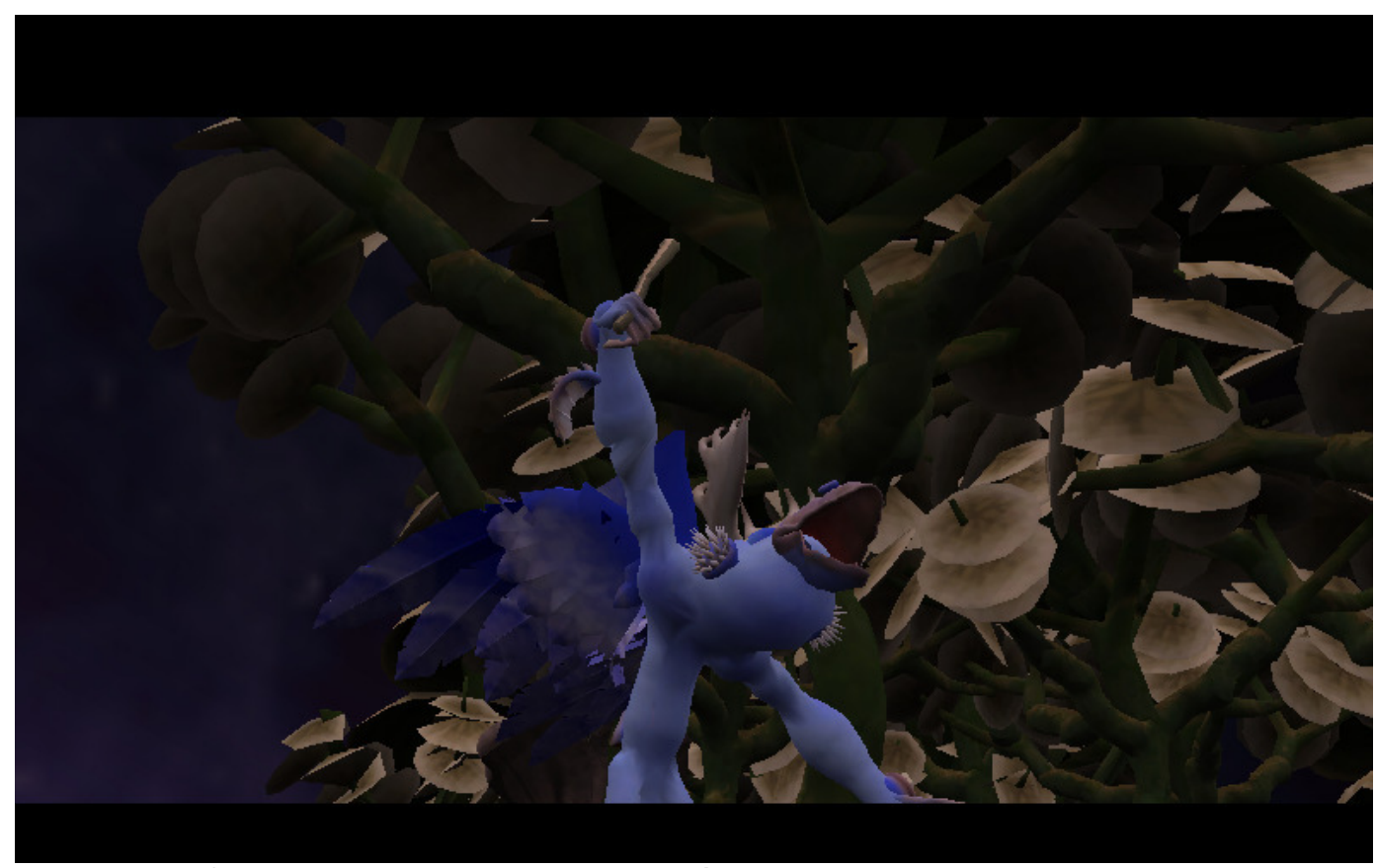

Ilustração 115 - Spore: tela da evolução para o estágio tribal com animação em alusão ao filme 2001: uma odisséia no espaço (1968, por Stanley Kubrick)

Fonte: Produção própria (durante pesquisa exploratória do jogo)

E, por fim, existe a troca de criaturas e criações possibilitada pela enciclopédia do jogo, o Sporepedia, onde os jogadores podem interagir e 
compartilhar suas experiências de jogo. Essa troca, além da interação social por interesse, promove a curiosidade sobre as ações e reações que possibilitam os resultados alcançados que são infinitos e personalizados.

\subsection{4 - Conclusão}

\section{Peculiaridades}

O Spore, desenvolvido pelos mesmos criadores de outras franquias clássicas de jogos para computador como o SimCity (simulador de criação e gerenciamento de cidades) e The Sims ("god" game de observação, influência e controle sobre o comportamento humano), apresenta características únicas por, exatamente, convergir a inteligência artificial contida em diversos jogos de desenvolvimento de personagens, gerenciamento de recursos em estratégia de tempo real e a subjetividade dos "god" games.

O interessante é a promoção geral de interatividade, onde o jogador, apesar de cumprir missões pré-definidas, tem total liberdade para criar seres, edifícios e automóveis personalizando-os conforme algumas formas básicas. Mas o jogador pode decidir sobre a localização, tamanho, cor e textura, montando seres e construções de forma muito aberta. Vale notar a possibilidade de interação com outros jogadores através da biblioteca de criações, o Sporepedia, onde pode-se compartilhar todas as experiências. O Sporepedia é acionado via o jogo e pode fazer parte de qualquer jogo, através da importação de criação.

Apesar de não ser estritamente rigoroso nos princípios científicos, o jogo apresenta temáticas importantes para a compreensão da evolução das espécies, segundo o predicado evolucionista de Darwin. Se torna, então, referência de partida para a estreita relação entre informação e ludicidade.

\section{Percepções do jogo}

O jogo foi analisado porque atribuía o predicado científico de evolucionismo de Darwin e para compreender e experimentar os desafios lúdicos dos jogos 
eletrônicos na linha de franquias de sucesso de mercado. De fato a análise demonstra que os fatores de conhecimento, estratégia e criatividade, ou seja, de formação, estão atrelados a aspectos de diversão, prazer, conquista, dificuldades e desenvolvimento próprios do meio lúdico.

Outra possível abordagem do Spore é que o jogo pode promover cenas e ações de violência, como é o caso das caças e guerras, ao mesmo tempo em que propõe soluções pacíficas de alianças, trocas comerciais, influências culturais, etc. $O$ jogador experimenta as vantagens e desvantagens de culturas mais violentas ou mais pacíficas, tendo um ponto de partida para discutir aspectos da história, cultura e geografia da humanidade, além de todas as questões da evolução das espécies e aspectos biológicos, já citados.

Sabe aquela vontade se ter poderes sobrenaturais para dominar os outros só para descobrir no que é que pode dar? Ou ainda, brincar de Deus e fazer o seu próprio Gênesis só pela vontade de ver uma criação sua evoluir? Pois é... o Spore promove tudo isso e um pouco mais...

Além de satisfazer em parte alguns desses desejos, o Spore mostra que o poder de criação pode levar a conseqüências inimagináveis, tanto para uma surpreendente satisfação, quanto para sustos imprevisíveis. E assim é a vida na qual fomos criados e jogados (tanto no sentido de ser colocados à força, quanto no sentido de estar à mercê de outras forças como um avatar). 


\section{5 - Análise sobre o Ragnarök Online}

\subsection{1 - Dados gerais}

\begin{tabular}{|l|l|}
\hline Nome & Ragnarök Online - Brasil \\
\hline Plataforma/ console & Computador (PC - sistema operacional Windows) \\
\hline Desenvolvimento & $\begin{array}{l}\text { Gravity (empresa sul-coreana); } \\
\text { Level Up! (distribuição no Brasil) }\end{array}$ \\
\hline Distribuição & $\begin{array}{l}\text { Software é gratuito para puxar e instalar; } \\
\text { Associação Premium (servidor Odin): a partir de } \\
\text { R\$ 9,90 (para 15 horas) } \\
\text { Associação Gratuita (servidor Thor) }\end{array}$ \\
\hline Classificação etária & $\begin{array}{l}\text { Não recomendado para menores de 12 anos } \\
19 / 05 / 2005 \text { (original - Coréia do Sul); } \\
17 / 04 / 2006 \text { (Brasil) }\end{array}$ \\
\hline Data de lançamento & $\begin{array}{l}\text { http://www.ragnarok.com (original) } \\
\text { http://www.levelupgames.com.br/ragnarok (Brasil) }\end{array}$ \\
\hline Site oficial
\end{tabular}

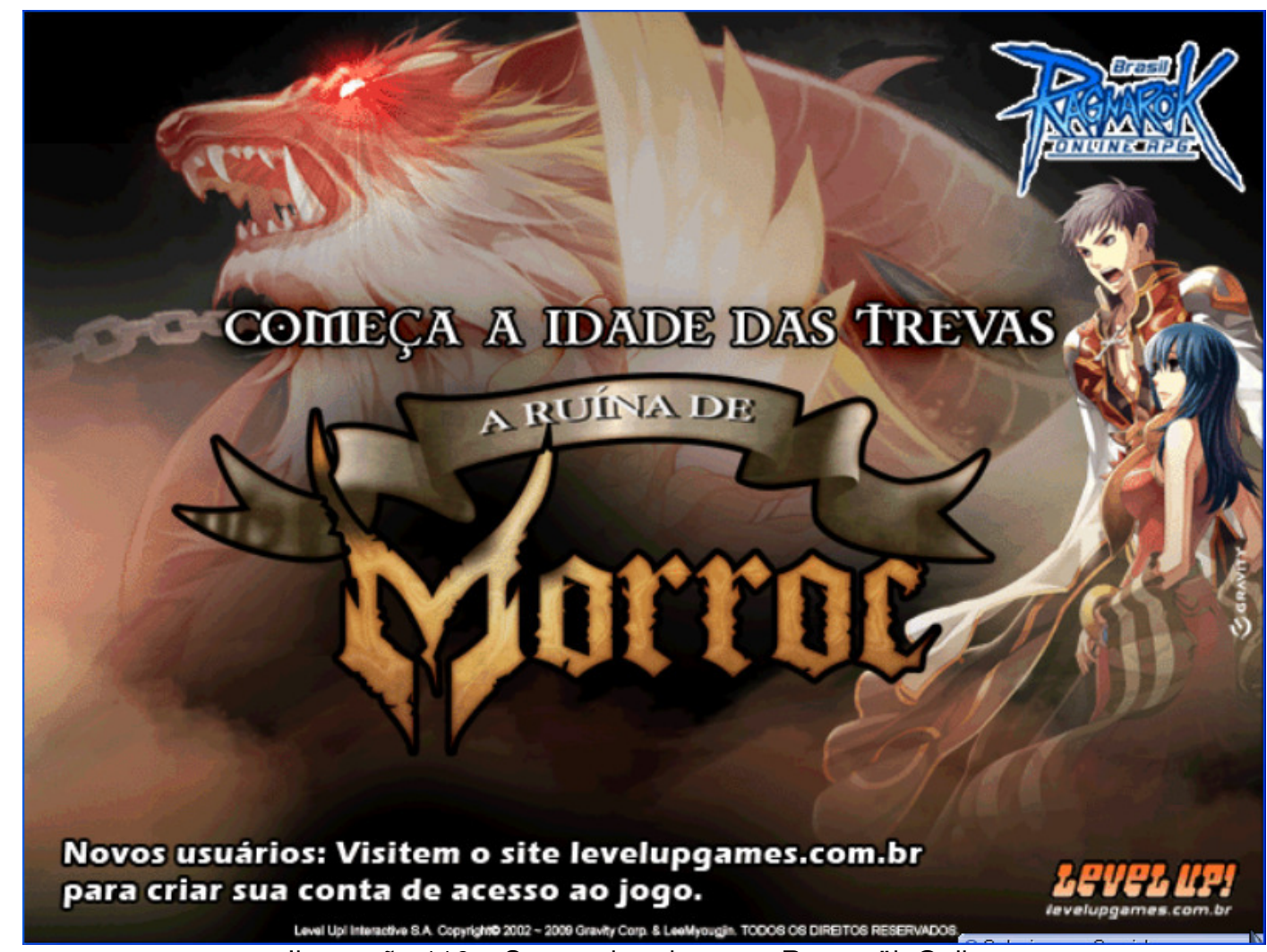

Ilustração 116 - Screenshot do game Ragnarök Online

Fonte: Produção própria (durante pesquisa exploratória do jogo) 


\subsection{2 - Design e Estrutura}

\begin{tabular}{|c|c|}
\hline Gênero & $\begin{array}{l}\text { MMORPG - Massive Multiplayer Online RPG: o jogo é um } \\
\text { RPG (Role Playing Game, jogo de atuação de papeis) online } \\
\text { e multiusuário, onde o jogador incorpora um personagem e } \\
\text { deve decidir o que fazer com ele (lutar, fugir, fazer compras, } \\
\text { evoluir, se curar, etc.), tendo outros jogadores para interagir e } \\
\text { acompanhar (formando alianças, determinando objetivos em } \\
\text { coletividade, lutando juntos, etc.) }\end{array}$ \\
\hline $\begin{array}{l}\text { Interfaces e } \\
\text { Jogabilidade }\end{array}$ & $\begin{array}{l}\text { O jogador dispõe de elementos visuais e sonoros } \\
\text { apresentados na tela do computador e utiliza teclado e } \\
\text { mouse para acionar comandos. O elementos visuais são } \\
\text { tridimensionais com renderização em cell shading, que } \\
\text { resulta em um tipo de imagem com sombreamento menos } \\
\text { realista, na linguagem dos desenhos animados 2D e das } \\
\text { revistas em quadrinhos. O jogador tem à disposição várias } \\
\text { janelas com vários botões e menus para visualizar e controlar } \\
\text { o estado do personagem e do mundo e pode acionar os } \\
\text { vários comandos através de janelas e abas específicas além } \\
\text { da possibilidade de utilizar várias teclas de atalhos. Um } \\
\text { jogador interage em tempo real com milhares de outros } \\
\text { jogadores que estiverem conectados, podendo conversar } \\
\text { através de balões tipo quadrinho (para falas públicas) e chat } \\
\text { (para conversas particulares). }\end{array}$ \\
\hline Objetivos & $\begin{array}{l}\text { O jogo não tem objetivos específicos a não ser o desafio para } \\
\text { que o jogador assuma o papel de um personagem criado por } \\
\text { ele mesmo e desenvolva a própria história a partir das suas } \\
\text { próprias escolhas. Existe o objetivo de fundo de extermínio } \\
\text { dos monstros (que são as forças malignas do enredo), mas a } \\
\text { sua existência é infinita e, portanto, servem mais para o } \\
\text { desenvolvimento dos personagens do que como objetivo } \\
\text { final. O grande desafio dessa categoria de jogos é } \\
\text { desenvolver o personagem, tornando-o mais forte e }\end{array}$ \\
\hline
\end{tabular}




\begin{tabular}{|c|c|}
\hline & $\begin{array}{l}\text { adquirindo habilidades e acessórios mediante o cumprimento } \\
\text { de certas tarefas e negociação com dinheiro virtual } \\
\text { (recebidodo após vitórias sobre monstros, vendas de itens e } \\
\text { execução de tarefas específicas). Outro grande desafio é a } \\
\text { formação de clãs e grupos com outros } \\
\text { personagens/jogadores a fim de realizar tarefas que exijam o } \\
\text { trabalho coletivo (matar monstros mais poderosos, por } \\
\text { exemplo). }\end{array}$ \\
\hline Narrativa & $\begin{array}{l}\text { Ragnarök é o conhecido "Crepúsculo dos deuses" da } \\
\text { mitologia nórdica, que descreve o momento apocalíptico das } \\
\text { batalhas entre os deuses guerreiros, liderados por Odin, o } \\
\text { grande deus, contra os gigantes, liderados por Loki, deus das } \\
\text { traições e mentiras. Rune-Midgar, o mundo do homens e } \\
\text { cenário do jogo, é contaminada pelas mentiras de Loki e } \\
\text { passa a sofrer um forte e interminável inferno para cenografar } \\
\text { a batalha entre os homens e a aparição de monstros. Para } \\
\text { começar, o jogador deve criar o seu personagem, definindo o } \\
\text { sexo, atributos físicos (cabelo, por exemplo), e atributos } \\
\text { específicos como força, agilidade, destreza, inteligência, } \\
\text { sorte e vitalidade. Conforme o desenvolvimento do } \\
\text { personagem, o jogador ganha pontos para distribuir entre } \\
\text { esses atributos. O jogador escolhe, ainda, a classe do } \\
\text { personagem, o que determinará a aquisição de determinadas } \\
\text { habilidades e acessórios específicos (para exemplos de } \\
\text { classes, é possível citar a primeira classe de Aprendiz e as } \\
\text { grandes vertentes iniciais de Espadachim, Mercador, Gatuno, } \\
\text { Arqueiro, Noviço, Mago e Taekwon que depois se } \\
\text { destrincham em várias outras classes dependendo do } \\
\text { desenvolvimento do personagem e das escolhas do jogador). } \\
\text { A formação de grupos e clãs promovem a interação e } \\
\text { fidelização do jogador ao jogo, com vínculos que vão além de } \\
\text { objetivos de um "terminar o jogo" para uma relação } \\
\text { duradoura com outros jogadores. }\end{array}$ \\
\hline
\end{tabular}




\subsection{3 - Aspectos de formação}

Tendo como base um universo amplo e complexo e a própria complexidade que compõe a formação e desenvolvimento único de cada personagem , o jogador de Ragnarök Online precisa interagir com o espaço se preocupando em encontrar e combater com monstros de forma ágil e eficiente, sempre atento com as condições do seu próprio avatar. Além disso, o Ragnarök Online se destaca por promover a interação entre vários jogadores e, assim, possibilitar uma experiência de jogo peculiar e sem pré-definições de desenvolvimento e trocas.

\section{Ativação sensorial}

O jogador tem um universo para explorar, com diversas paisagens (cidades, desertos, pântanos, cavernas, etc.) na sua procura por combates com monstros que aumentarão o nível de experiência do seu avatar. Para encontrar os monstros, o jogador deve aprimorar o seu olhar sobre as diversas paisagens caçando os monstros que pode combater e fugindo dos monstros mais fortes para evitar ser morto.

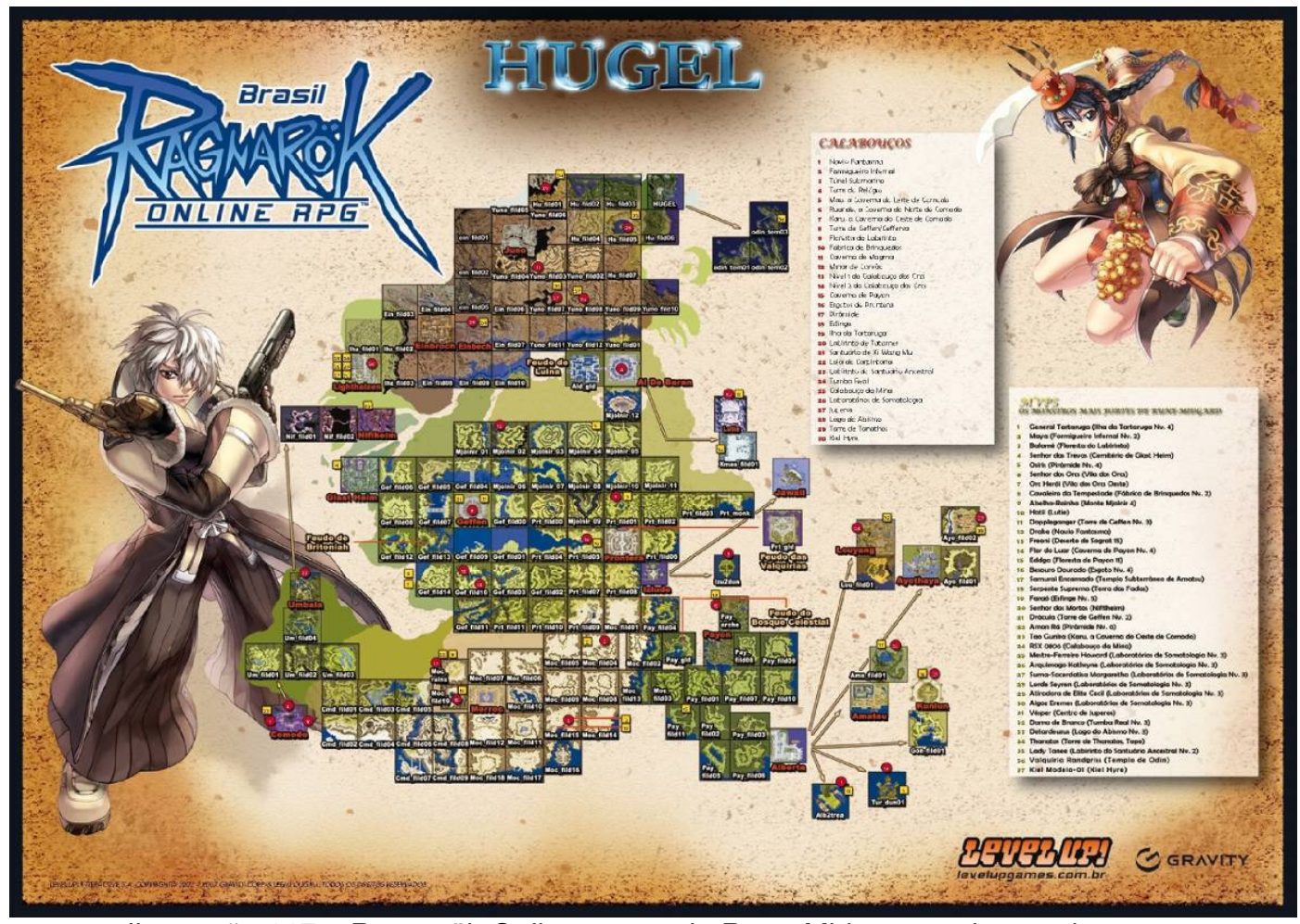

Ilustração 117 - Ragnarök Online: mapa de Rune-Midgar, o universo do game Fonte: http://games.levelupgames.uol.com.br/ragnarok/ (Acesso em: 25 abr.2009) 


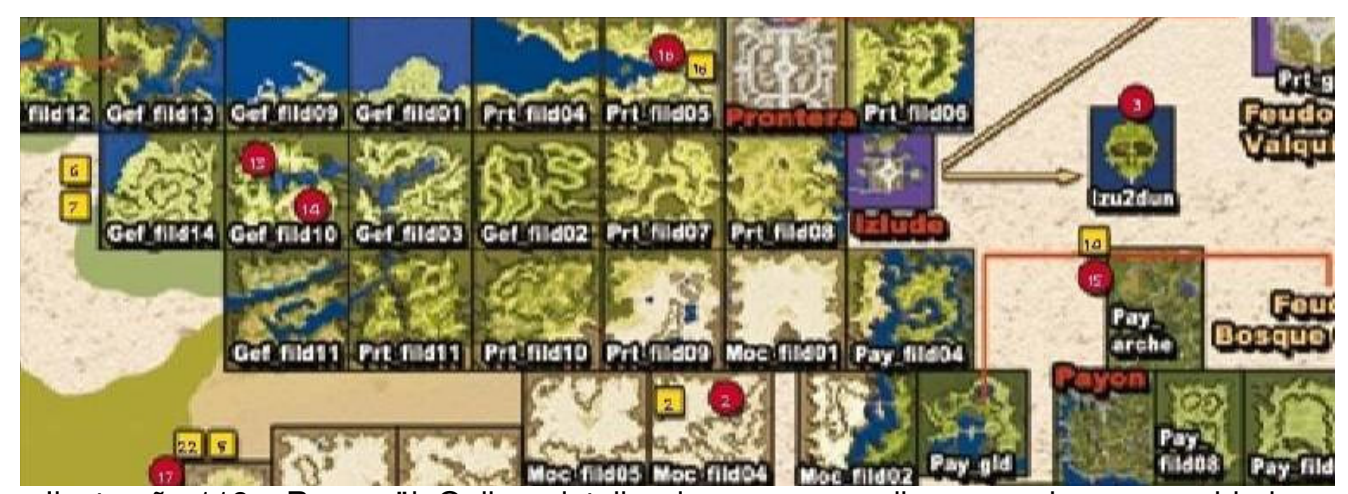

Ilustração 118 - Ragnarök Online: detalhe do mapa, com diversas paisagens e cidades Fonte: http://games.levelupgames.uol.com.br/ragnarok/ (Acesso em: 25 abr.2009)
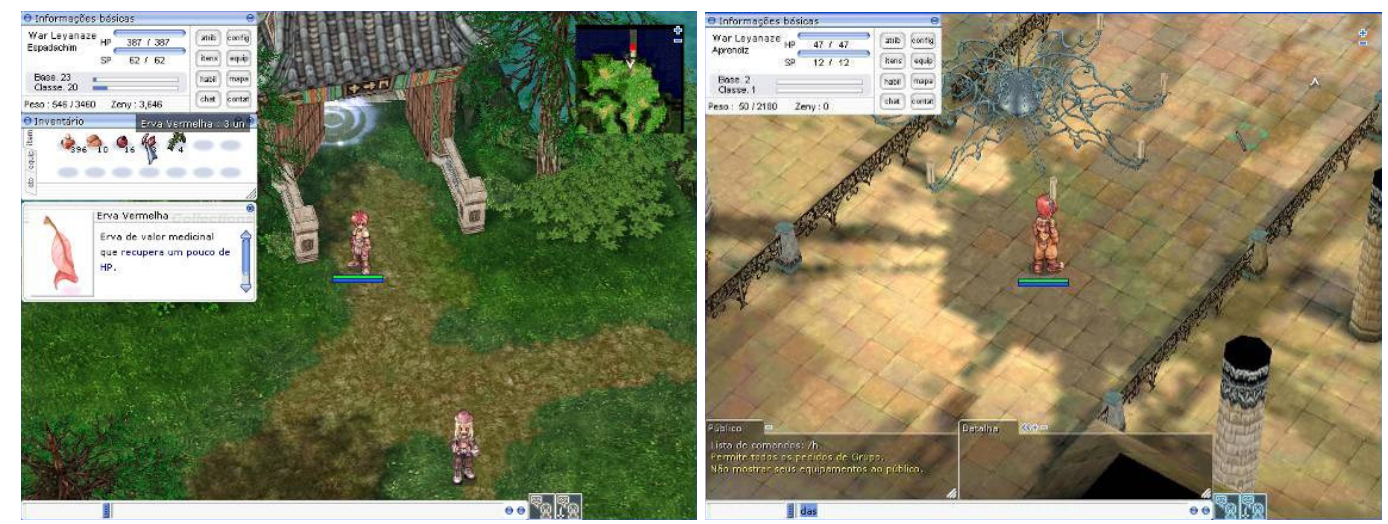

Ilustração 119 - Ragnarök Online: explorando os ambientes do jogo

Fonte: Produção própria (durante pesquisa exploratória do jogo)

Conforme for aumentando o seu nível, o personagem pode aprimorar os seus atributos de força, agilidade, destreza, inteligência, sorte e vitalidade aumentando além de otimizar as suas habilidades de combate, cura, criação, etc. A decisão de como aumentar os atributos e potencializar as habilidades fica a cargo do jogador que, normalmente, procura otimizar as suas condições de combate.
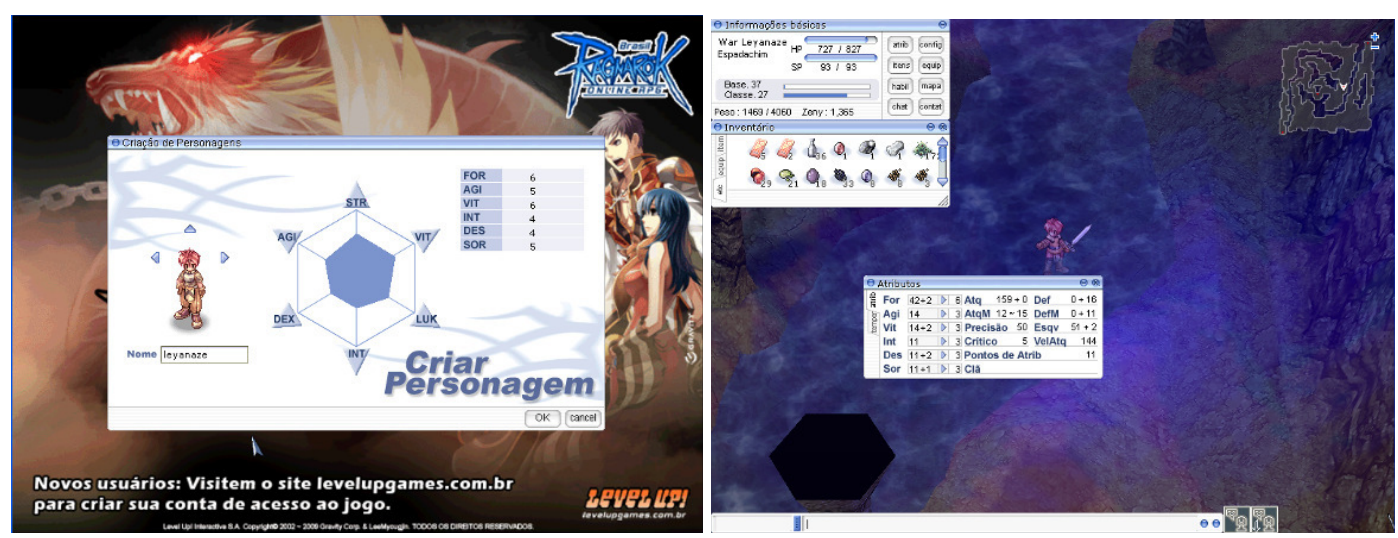

llustração 120 - Ragnarök Online: telas de atributos e evolução do personagem Fonte: Produção própria (durante pesquisa exploratória do jogo)

Reflexo e resposta 
A principal exigência ao jogador em termos de reflexo acontece nos momentos de batalha onde se deve acionar agilmente os comandos mais eficientes para o combate. Com as várias habilidades de combate e cura, o jogador deve decidir e acionar comandos por teclas de atalhos e botões nas diversas janelas do jogo que promovam o ataque, o lançamento de veneno e magias, uso de itens de cura, entre outras possíveis ações.

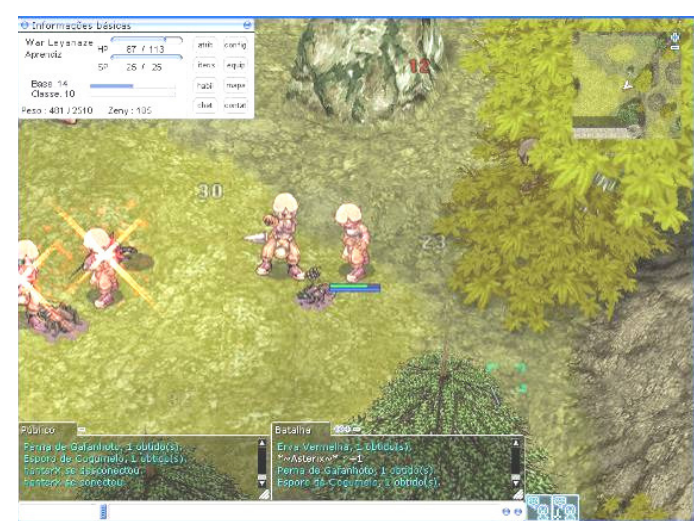

Ilustração 121 - Ragnarök Online: combates com os monstros Fonte: Produção própria (durante pesquisa exploratória do jogo)

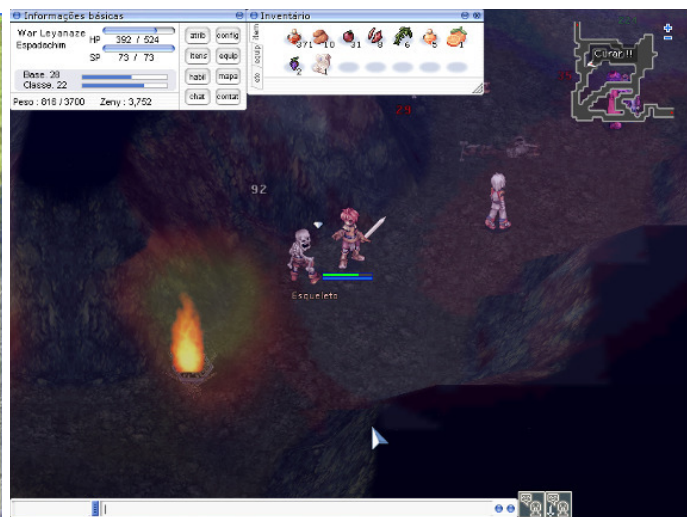


Numa possível forma de evitar a morte, no momento em que estiver com o nível de vida baixo, o jogador pode descansar para recuperar a energia do personagem.

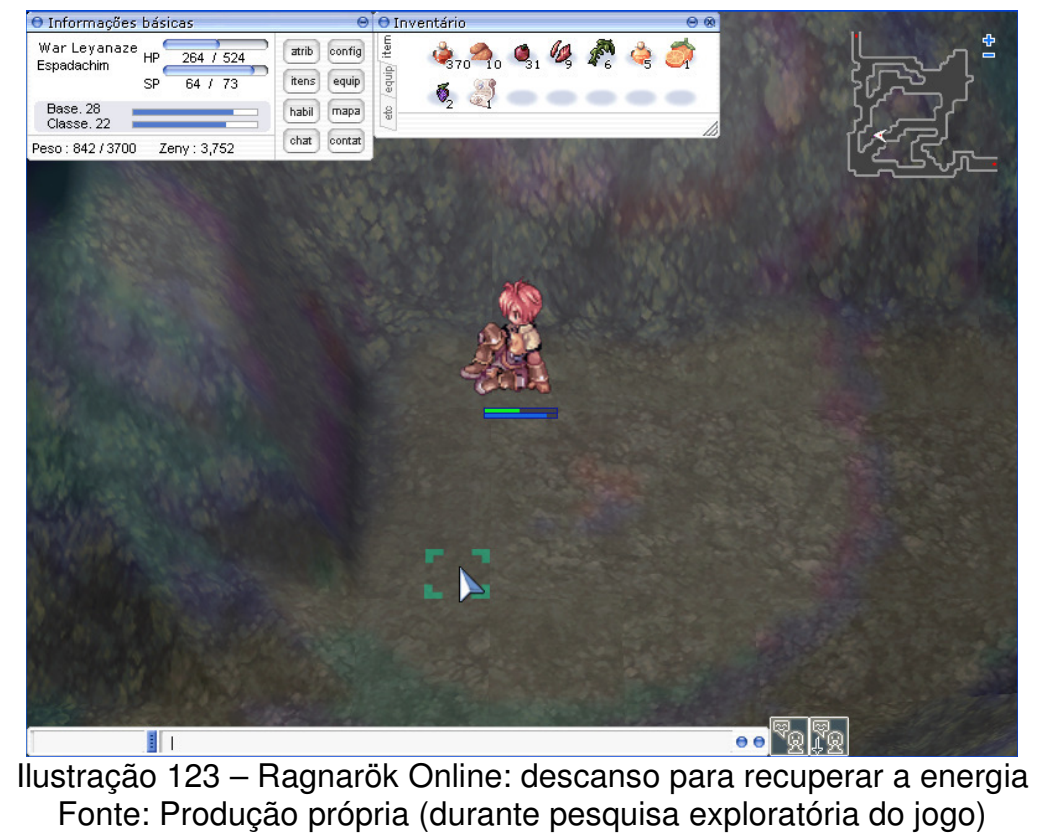

Ao morrer, monstros podem deixar "cair" objetos e itens que o jogador pode obter a fim de usar em combate ou vender e negociar em lojas ou com outros jogadores para ter dinheiro para comprar equipamentos, armas, acessórios, etc.

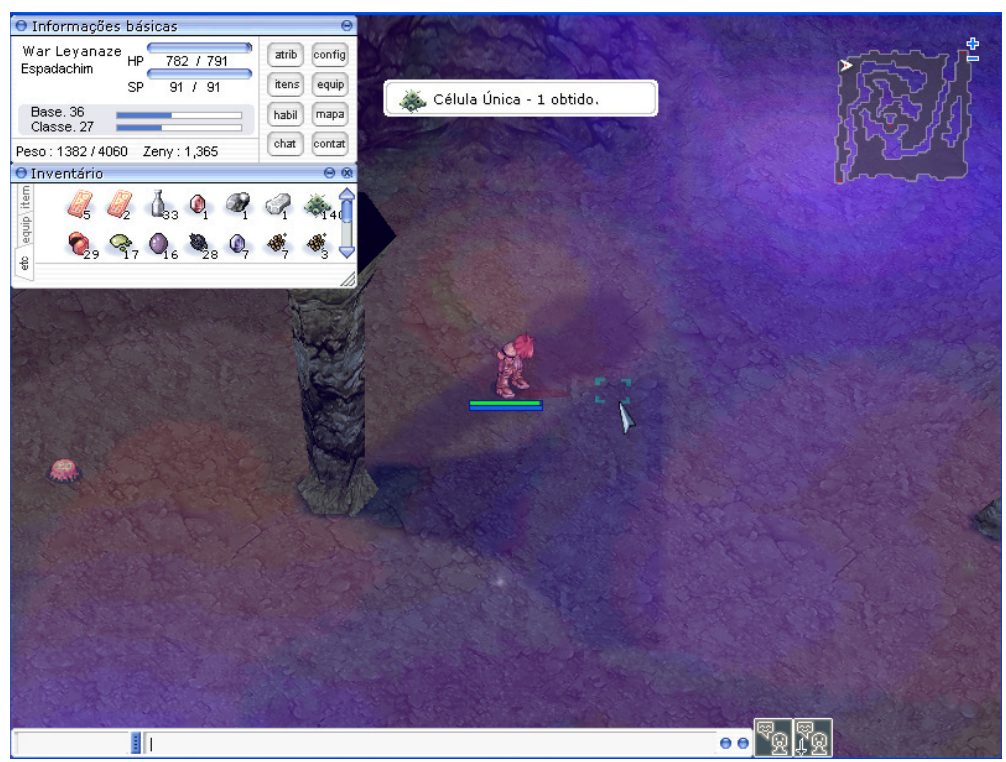

Ilustração 124 - Ragnarök Online: obtendo itens após combate com monstro Fonte: Produção própria (durante pesquisa exploratória do jogo) 


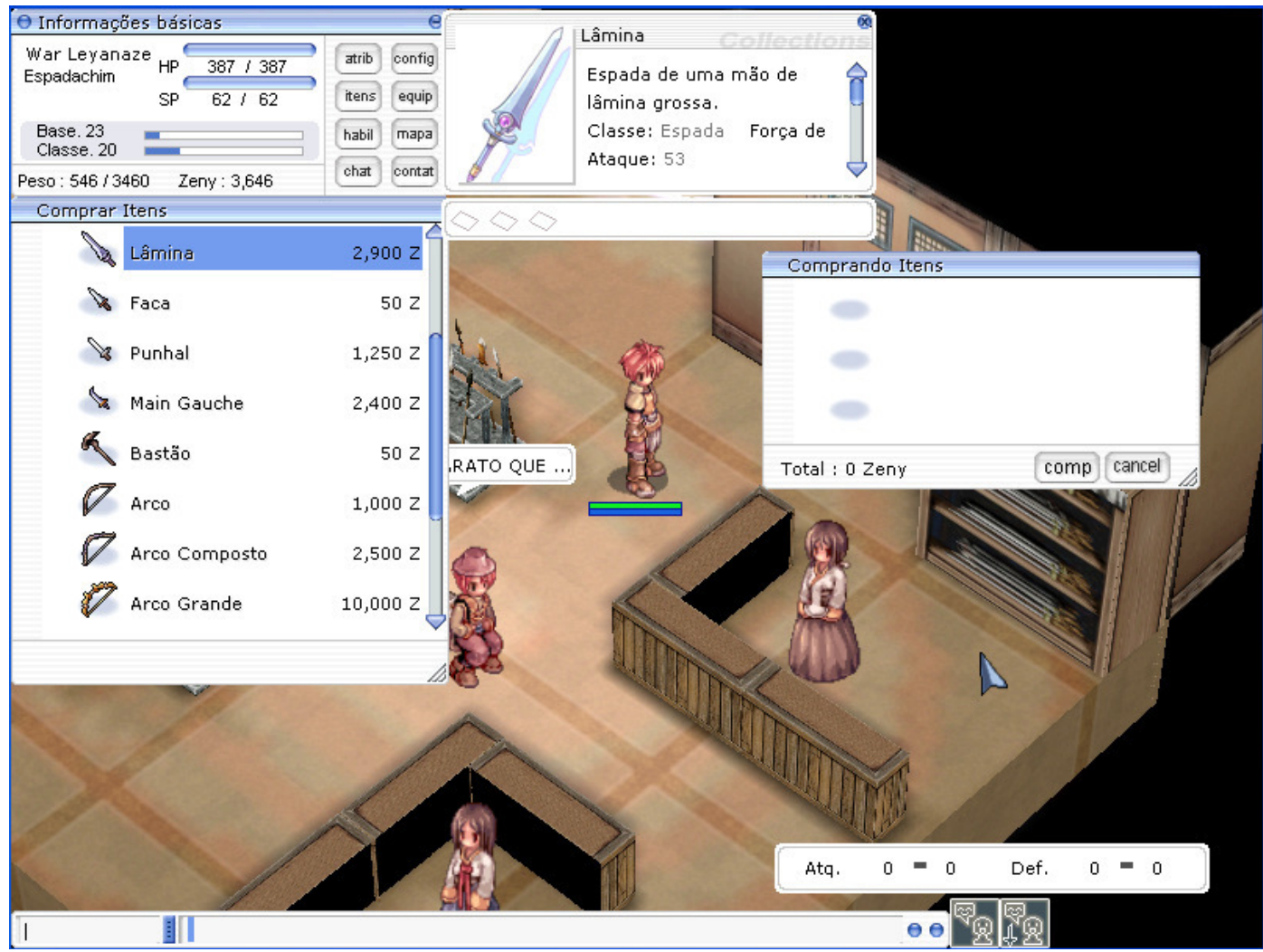

Ilustração 125 - Ragnarök Online: negociando equipamento em loja Fonte: Produção própria (durante pesquisa exploratória do jogo)
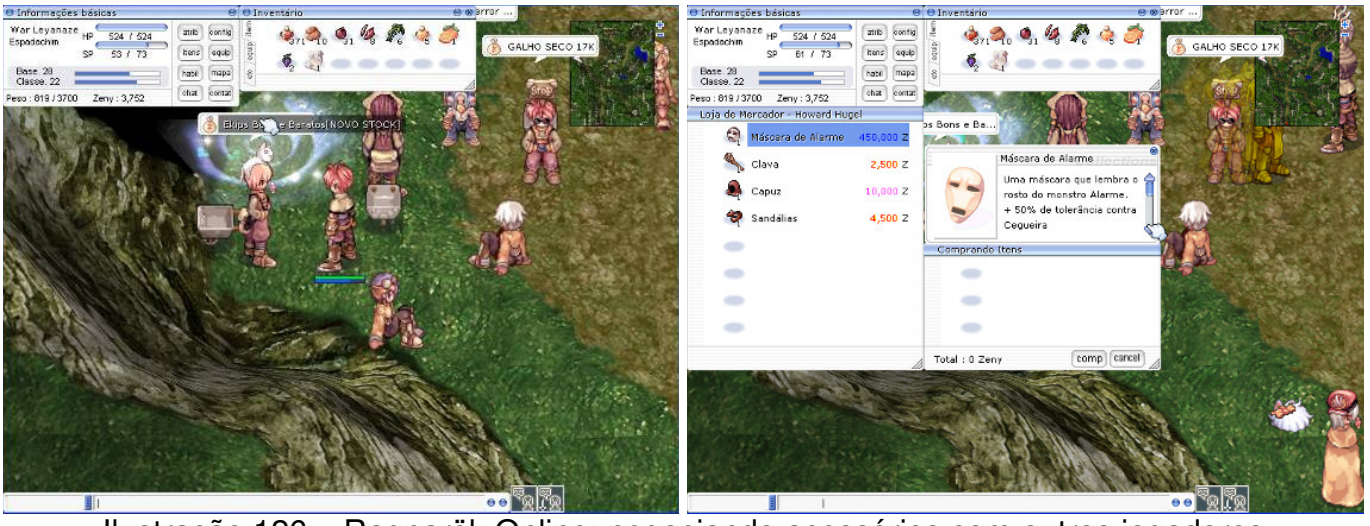

llustração 126 - Ragnarök Online: negociando acessórios com outros jogadores

Fonte: Produção própria (durante pesquisa exploratória do jogo)

\section{Conteúdo informacional}

O destaque dos MMORPG e, especificamente do Ragnarök Online, é a interação promovida com outros jogadores,incentivando as relações sociais através das trocas necessárias para sobreviver e se desenvolver principalmente pela formação de clãs e grupos, ação e decisão coletivas e trocas de experiência, informação e mercadorias. 
Em praticamente qualquer lugar do jogo existem outros jogadores para poder interagir, seja para negociar itens ou para formar alianças. É possível, ainda, encontrar alguns jogadores que dividem informação sobre o jogo, em termos de como conseguir evoluir mais rapidamente e quais equipamentos são mais eficientes.

Nas cidades, com a concentração de pessoas à procura de equipamentos, armas, itens de recuperação e acessórios, existem vários jogadores com interesse em comercializar produtos. É possível, também, adquirir bichos de estimação, que auxiliam nas batalhas, e animais para transporte, que aumentam a agilidade do personagem.

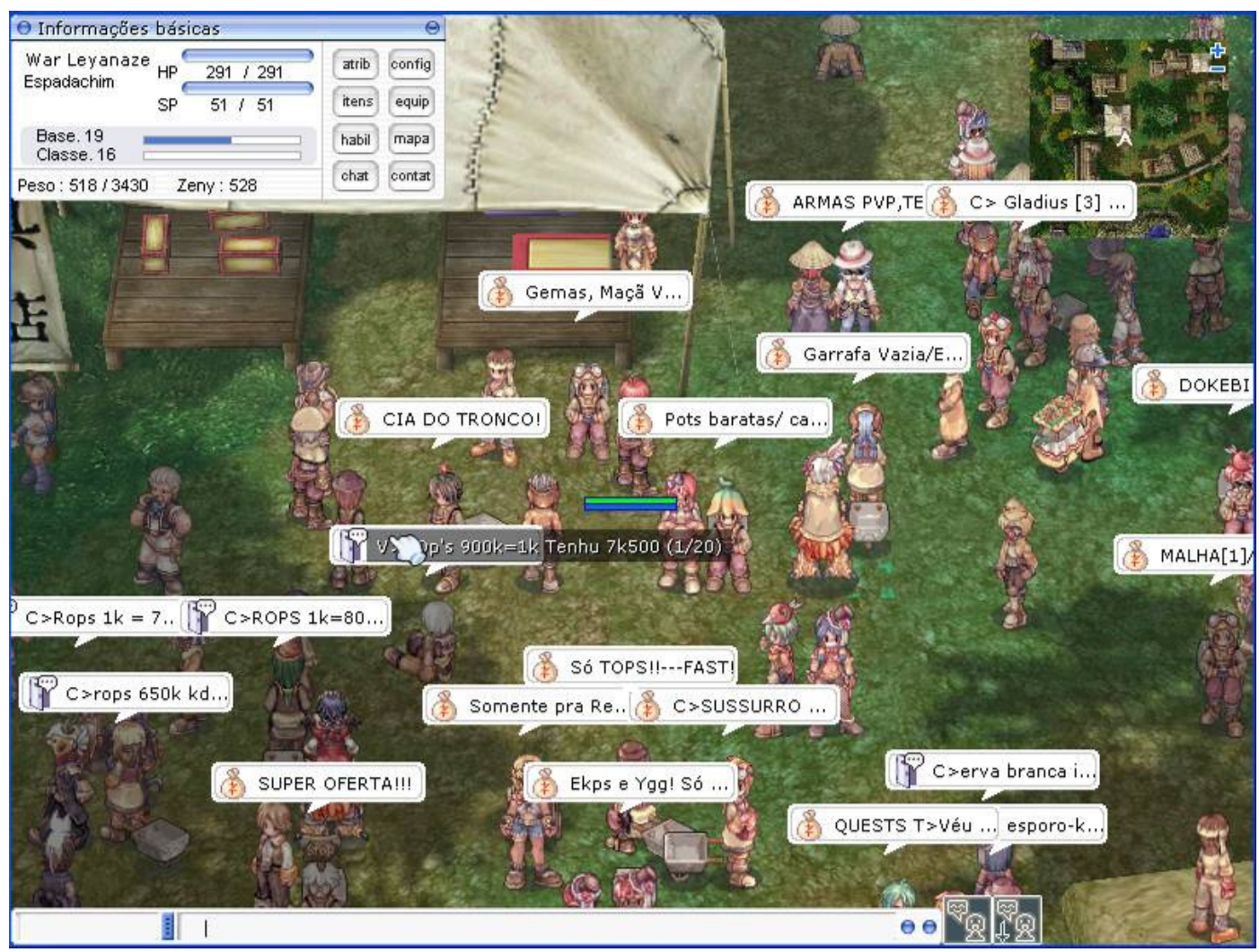

Ilustração 127 - Ragnarök Online: concentração de jogadores nos "centros urbanos" Fonte: Produção própria (durante pesquisa exploratória do jogo)

Já nos campos de batalha, é possível encontrar jogadores com o objetivo comum de combater monstros para ganhar experiência, estando mais propícios para formar alianças temporárias para batalhar com monstros mais fortes. Freqüentemente um grupo anda por várias horas juntos, decidindo através de chats e conversas particulares os destinos e alvos, dividindo os pontos de experiência e os itens deixados pelos monstros. 


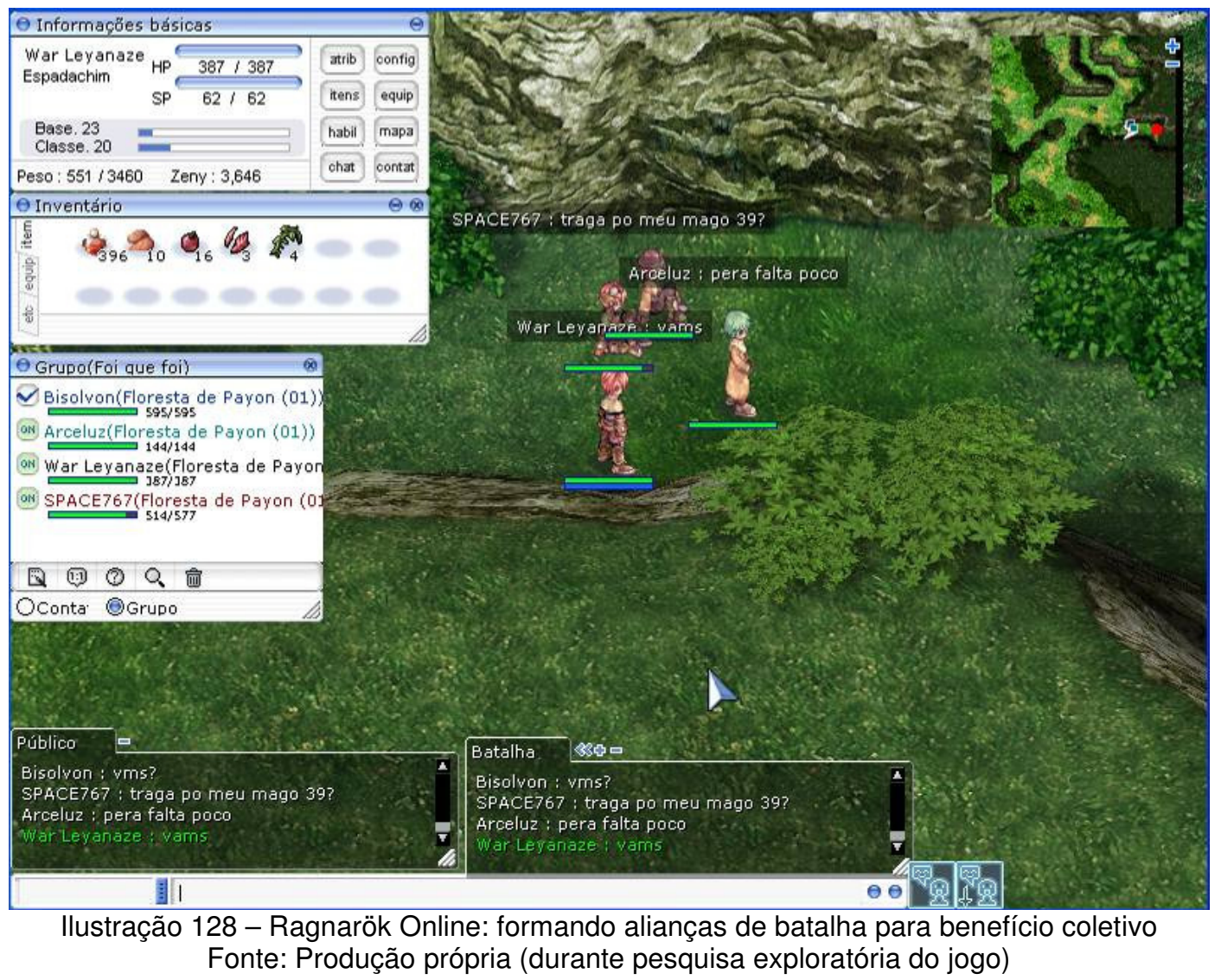

Além da interação através da negociação de itens e das alianças de combate, os jogadores ainda podem formar clãs que vão muito além da convivência temporária. Sendo membro de um clã, o jogador tem responsabilidades para com os demais membros, respondendo a requisições em tarefas especiais e, quando for o caso, auxiliando com dinheiro e serviços requisitados pelo líder. Além disso, por duas vezes em uma semana os clãs têm a oportunidade de batalhar entre si para conquistar castelos espalhados pelo universo de Ragnarök Online. Tendo posse de um castelo, o clã tem várias regalias de proteção e abastecimento.

Algumas alianças podem se caracterizar pela identificação afetiva dos jogadores que podem, então, "casar" dentro do universo de Ragnarök Online. O casamento também permite novas habilidades e até a possibilidade de adotar personagens de outros jogadores como filhos. O jogo em "família" permite novas habilidades que facilitam a recuperação de energia e permitem novas experiências de interação dentro do jogo. 


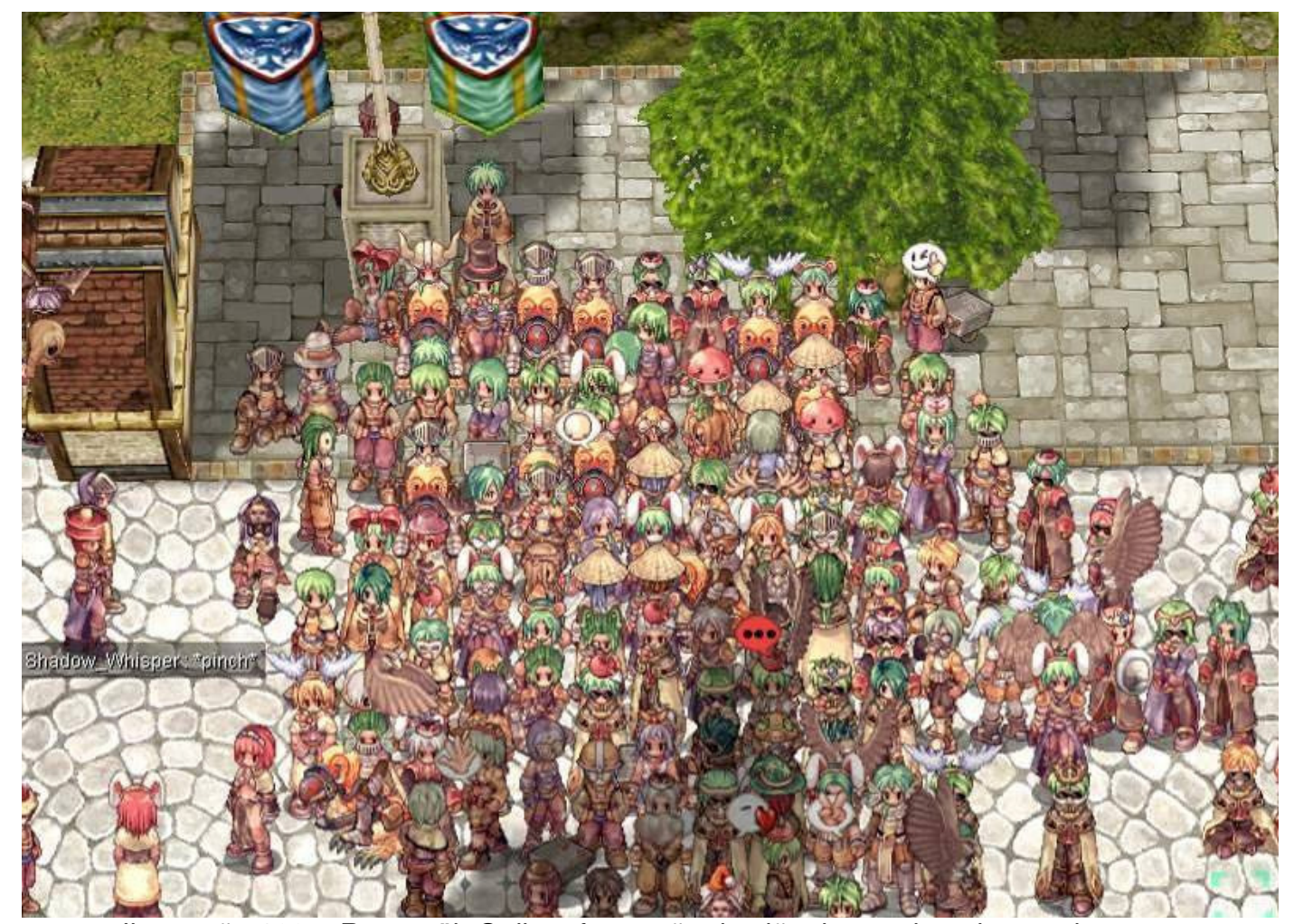

Ilustração 129 - Ragnarök Online: formação de clãs dentro do universo do game Fonte: http://games.levelupgames.uol.com.br/ragnarok/ (Acesso em: 25 abr.2009)

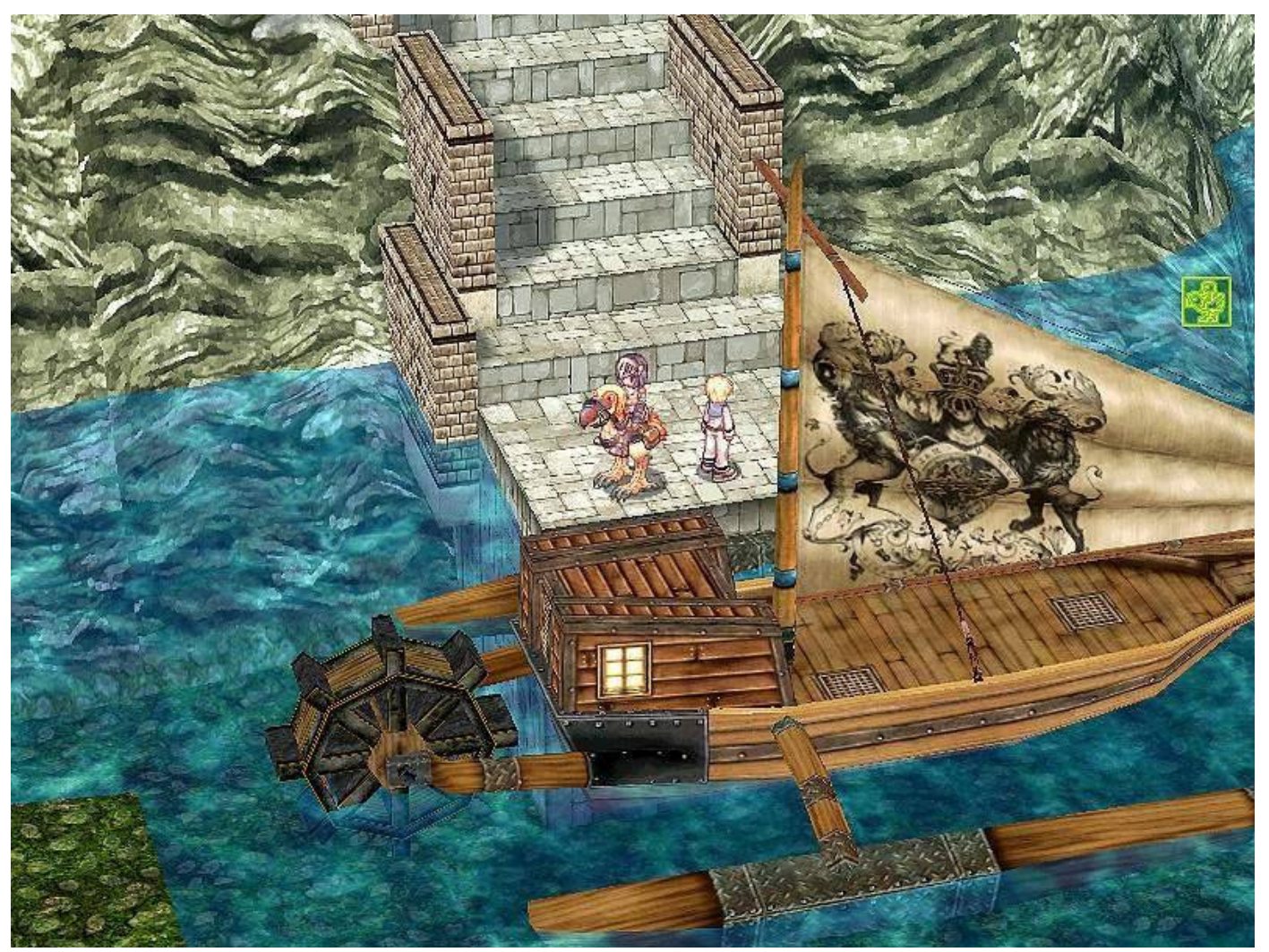

Ilustração 130 - Ragnarök Online: encontros íntimos em um outro nível de interação Fonte: http://games.levelupgames.uol.com.br/ragnarok/ (Acesso em: 25 abr.2009) 


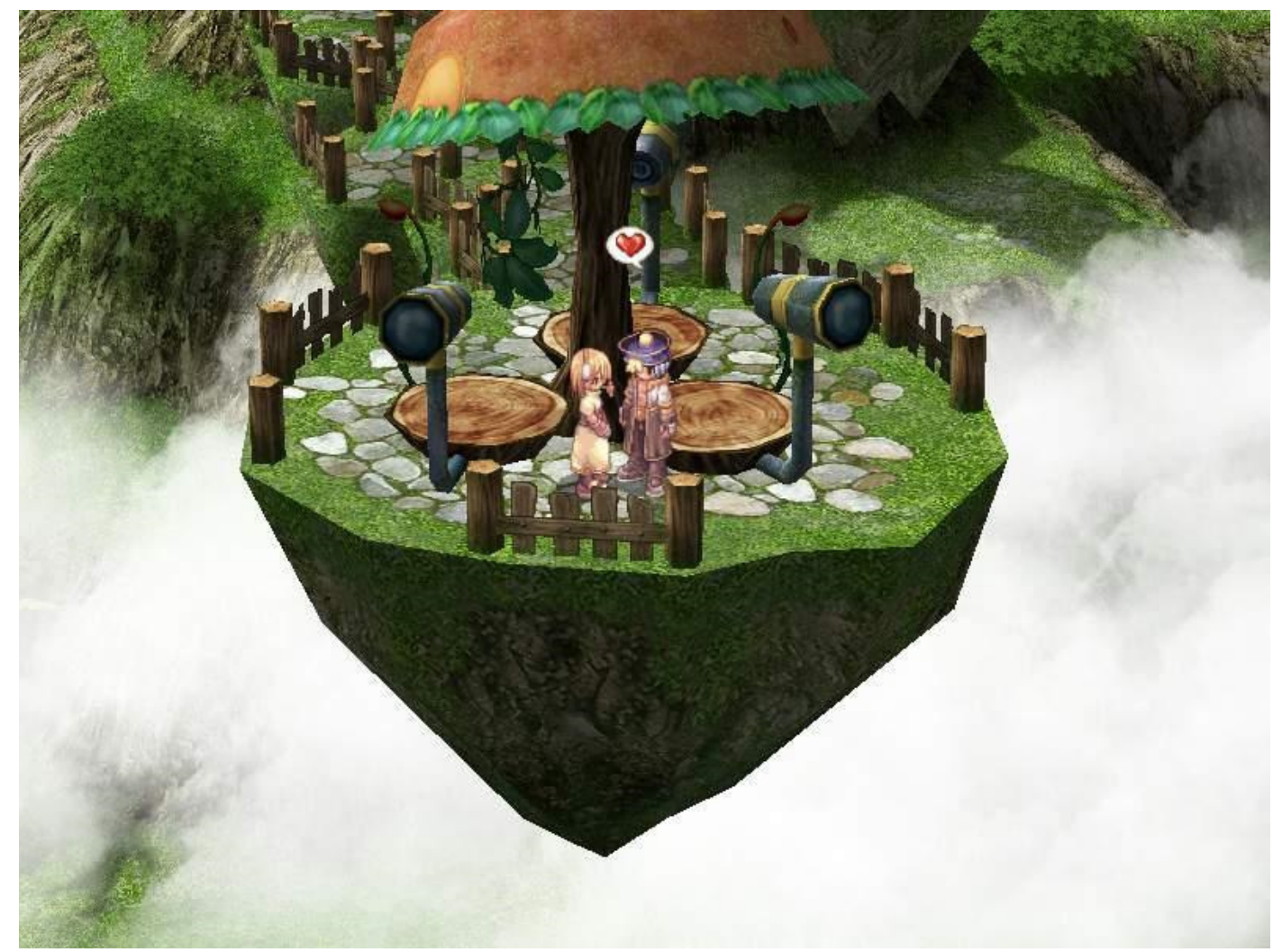

llustração 131 - Ragnarök Online: formação de famílias dentro do universo do game Fonte: http://games.levelupgames.uol.com.br/ragnarok/ (Acesso em: 25 abr.2009)

\subsection{4 - Conclusão}

\section{Peculiaridades}

Destaca-se de Ragnarök Online a interação entre os jogadores promovida pela interface de game, onde o jogador não segue pré-determinações elaboradas em um código, mas responde e intervém em ações conjuntas e coletivas com outros indivíduos. É interessante notar que a alteridade faz parte do contexto desse jogo e que os objetivos e motivações, ou seja, o aspecto lúdico está justamente no encontro com outros jogadores e não somente no simples realizar de desafios que são colocados de forma arbitrária.

É importante destacar o sucesso de Ragnarök Online no Brasil que, a exemplo do que aconteceu com o Second Life, também encontrou forte aceitação entre os brasileiros a ponto de contar com distribuição nacional própria, fato que ocorreu em poucos países. A popularização do jogo reforça os aspectos de socialização e interação que tanto caracteriza os brasileiros digitais. 
E essa proposta de Ragnarök Online de promover interação entre vários jogadores é adotada nos diversos jogos massive multiplayer online, os jogos em rede com multiusuários, comprovando a importância da categoria envolvendo, inclusive, famosas franquias do cinema como, por exemplo, Star Wars Galaxies, The Matrix Online e The Lord Of The Rings Online, que levam os jogadores aos universos interativos e multiusuários de Guerra das Estrelas, Matrix e O Senhor dos Anéis, respectivamente.

\section{Percepções do jogo}

Alguns artigos e reportagens atentam para os perigos de isolamento e dessocialização que os games podem provocar. Contrariando tal pensamento, Ragnarök Online e todos os jogos em rede com multiusuários mostram o potencial de socialização dos games, já que o maior objetivo de tais jogos é justamente o fortalecimento dos personagens através das alianças e negociações.

A disseminação de informações sobre o game ultrapassa a própria interface do jogo e acontece também em fóruns, blogs e outras plataformas de comunidades virtuais, ressaltando a percepção da função social do jogo. Várias informações que promovem a melhor experiência do jogo se encontram em sites e em outros pontos de encontro e disseminação digital. 


\section{6 - Análise sobre o Cozinheiro das Almas}

\subsection{1 - Dados gerais}

\begin{tabular}{|l|l|}
\hline Nome & Cozinheiro das Almas \\
\hline Plataforma/ console & Game para computador (PC - Windows) \\
\hline Desenvolvimento & Grupo de Pesquisa Poéticas Digitais (ECA-USP) \\
\hline Distribuição & Sem preço, distribuição fechada \\
\hline Classificação etária & Não se aplica \\
\hline Data de lançamento & $2005-2006$ \\
\hline Site oficial & http://www.cap.eca.usp.br/poeticas/?page_id=28 \\
\hline
\end{tabular}

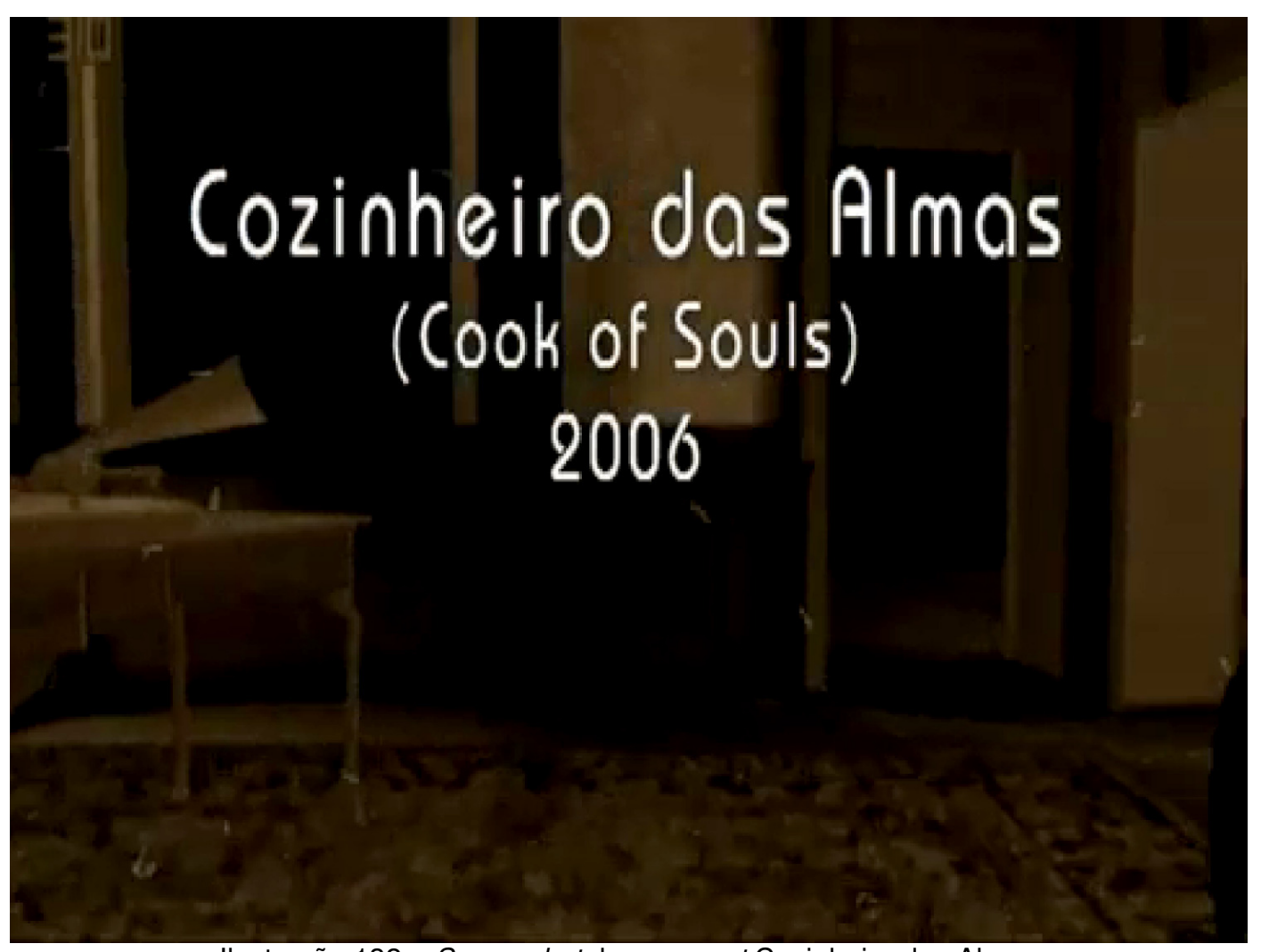

Ilustração 132 - Screenshot do game-art Cozinheiro das Almas

Fonte: http://www.cap.eca.usp.br/poeticas/?page_id=28 (Acesso em: 08 jan.2009) 


\subsection{2 - Design e Estrutura}

\begin{tabular}{|c|c|}
\hline Gênero & $\begin{array}{l}\text { Adventure e ação: o jogador busca a solução de desafios e } \\
\text { enigmas que são construídos na narrativa do jogo para } \\
\text { prosseguir pelas fases e estágios, respondendo em tempo } \\
\text { real. }\end{array}$ \\
\hline $\begin{array}{l}\text { Interfaces e } \\
\text { Jogabilidade }\end{array}$ & $\begin{array}{l}\text { O jogador conta com uma câmera em primeira pessoa (o que } \\
\text { está na tela simula a visão do personagem), sendo que os } \\
\text { botões direcionais do teclado simulam o seu movimento no } \\
\text { espaço, enquanto a movimentação do mouse rotaciona o } \\
\text { ângulo de visão. Os ambientes são tridimensionalmente } \\
\text { construídos com qualidade de textura e mapas de sombras } \\
\text { sofisticadas. Nota-se um uso espacial de elementos sonoros } \\
\text { em estéreo onde o jogador, ao aproximar o personagem de } \\
\text { determinadas regiões e situações, captura maior volume de } \\
\text { som. O jogo é construído com base na engenharia de game } \\
\text { (game engine) 3D Game Studio, que tem interface apropriada } \\
\text { para a elaboração de jogos tridimensionais de ação e } \\
\text { aventura, sendo intuitivo e alcançando resultados bastante } \\
\text { satisfatórios em termos de gráfico e desempenho. }\end{array}$ \\
\hline Objetivos & $\begin{array}{l}\text { Como projeto experimental do Grupo de Pesquisa Poéticas } \\
\text { Digitais (ECA-USP), coordenado pelo professor Dr. Gilbertto } \\
\text { Prado, o jogo Cozinheiro das Almas tem a proposta de criar } \\
\text { uma plataforma de game que resulte de pesquisas e análises } \\
\text { históricas da estética literária, plástica e arquitetônica do } \\
\text { Brasil e, especificamente, de São Paulo do começo do século } \\
\text { XX, através da elaboração de ambientes, móveis e } \\
\text { vestuários. Analisando o jogo em si, a princípio, não são } \\
\text { apresentados objetivos claros sobre o que procurar e sobre } \\
\text { os desafios e enigmas da narrativa. O jogador parece estar } \\
\text { imerso em ambientes onde, intuitivamente e gradativamente, } \\
\text { descobre o enredo fragmentado que compõe a sua } \\
\text { experiência pelo simples contato com espaços e objetos. }\end{array}$ \\
\hline
\end{tabular}




\begin{tabular}{|l|l|}
\hline Os documentos-base do jogo elaborado pelo Grupo de \\
Pesquisa Poéticas Digitais (ECA-USP) ${ }^{4}$ apresentam os \\
conceitos empregados no desenvolvimento do jogo O \\
Cozinheiro das Almas. O game é baseado na obra literária "O \\
Perfeito Cozinheiro das Almas deste Mundo" de Oswald de \\
Andrade que é, de fato, a composição do diário do autor em \\
que relata o seu relacionamento amoroso com a normalista \\
Maria de Lourdes Castro de Andrade, também chamada de \\
Deisy e Ciclone que era guardado em sua garçonnière, na \\
rua Líbero Badaró, 67, 3o andar. Sob pseudônimos, o diário \\
era escrito continuamente por Oswald, Deisy, Monteiro \\
Lobato, Guilherme de Almeida, entre outros. Na vida real \\
Deisy contrai tuberculose e morre aos 19 anos, após uma \\
semana depois de se casar com Oswald em estado já \\
terminal. O jogo em si não apresenta uma narrativa linear \\
com definições explícitas sobre objetivos, missões e fases. O \\
desafio do jogo é justamente vivenciar e compreender a \\
lógica caótica do labirinto temporal e espacial que constitui a \\
mecânica narrativa do game. Os saltos temporais e espaciais \\
começam basicamente em 2005 no espaço abandonado do \\
que teria sido a garçonnière de Oswald de Andrade. De \\
repente o jogador é transportado para a garçonnière em 1918 \\
em um ambiente fielmente cenografado. Daí, ao encontrar \\
uma poção verde e tocá-la, o jogador de repente é \\
transportado para a Escola Normal, edif́cio que atualmente \\
abriga a Secretaria da Educação, na Praça da República, \\
onde vive, ao longo das horas do dia, entardecer e noite, a \\
experiência de visitar espaços e momentos, encontrando \\
vultos e vozes de pessoas presas no tempo. A narrativa se \\
constitui exatamente da não linearidade temporal e do \\
labirinto do tempo e do espaço.
\end{tabular}

${ }^{4}$ Textos disponibilizados no site http://www.cap.eca.usp.br/poeticas/?page_id=28 (Acesso em: 23 mar.2009) 


\subsection{3 - Aspectos de formação}

\section{Ativação sensorial}

Em termos de ativação sensorial, ou seja, os estímulos que o jogo promove no jogador, é possível destacar a experiência da visão e audição como principais elementos de interface na qual o jogador interage com o game.

O Cozinheiro das Almas é construído com base na engenharia de game (game engine) do 3D Game Studio, uma plataforma comercial de bom desempenho que promove, principalmente, o desenvolvimento de jogos tridimensionais de aventura e ação (incluindo os famosos jogos de tiro em primeira pessoa). A qualidade gráfica permitida por tal plataforma se assemelha a muitos jogos de sucesso da sexta geração de videogames e, portanto, condicionou que o Cozinheiro das Almas apresentasse uma excelente qualidade gráfica com elaborada construção de ambientes e elementos de época para reforçar a sua narrativa de viagem no tempo e espaço de diversos momentos da São Paulo do início do século XX.
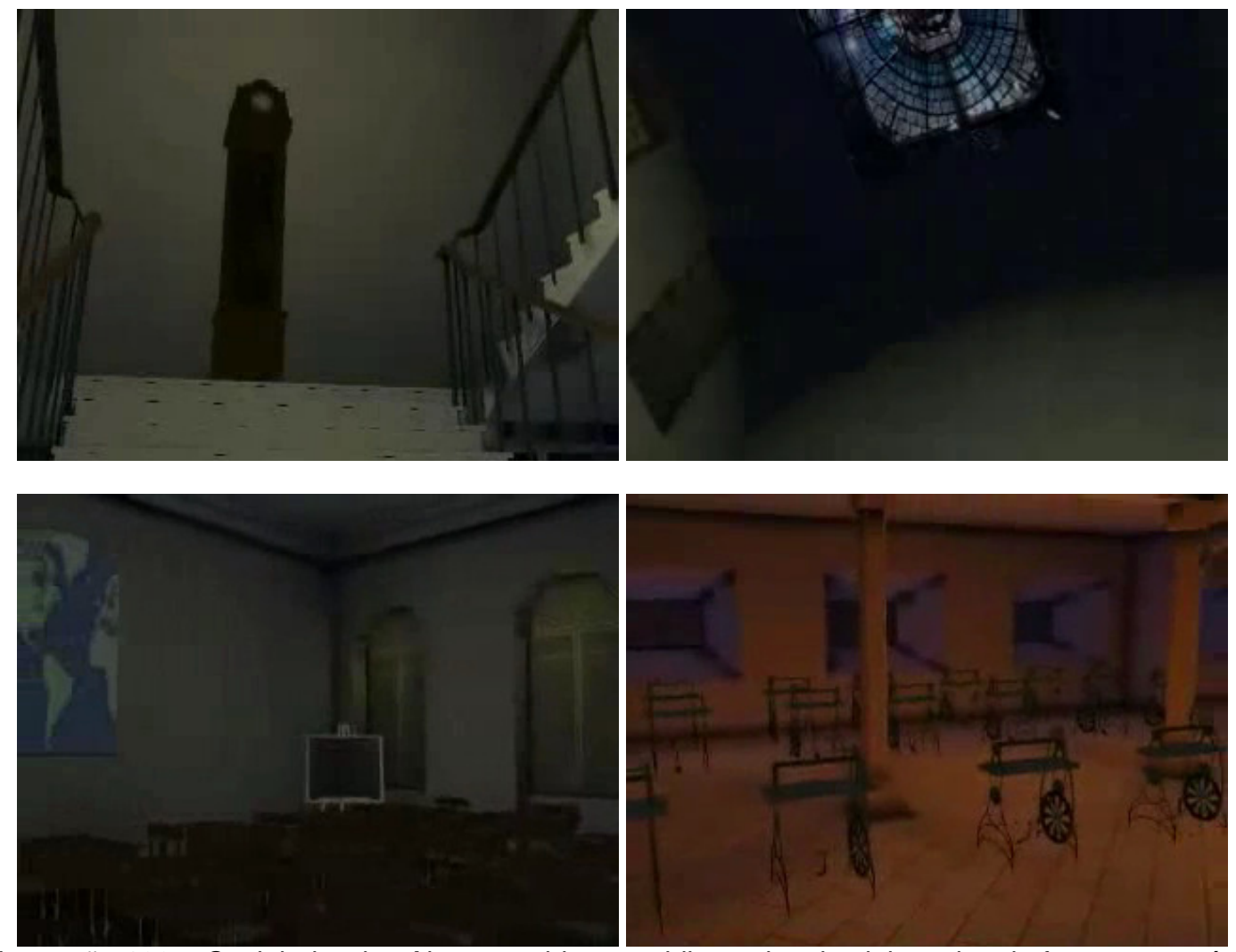

Ilustração 133 - Cozinheiro das Almas: ambientes tridimensionais elaborados de forma verossímil para caracterizar época

Fonte: http://www.youtube.com/watch?v=fh4kDjTuLbY (Acesso em: 25 mar.2009) 

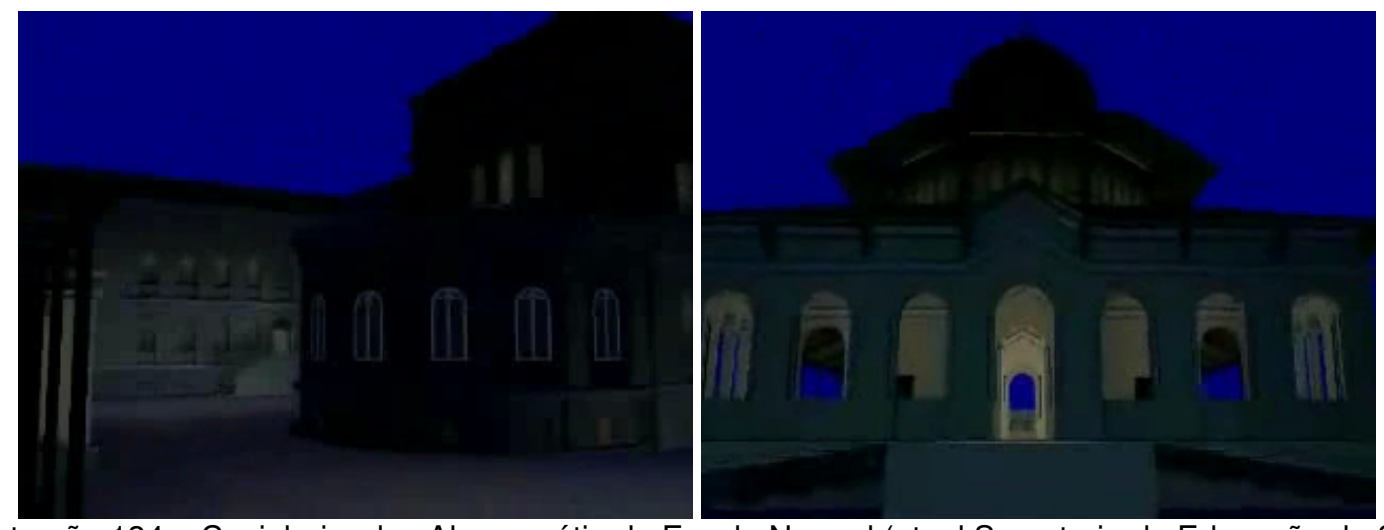

Ilustração 134 - Cozinheiro das Almas: pátio da Escola Normal (atual Secretaria da Educação de São Paulo), à noite

Fonte: http://www.youtube.com/watch?v=fh4kDjTuLbY (Acesso em: 25 mar.2009)

Junto com o desempenho gráfico, o Cozinheiro das Almas apresenta uma boa qualidade de som que é explorada também de forma tridimensional. Ao se aproximar das fontes emissoras de som, principalmente caracterizadas por aglomerados de pessoas, o volume do som se intensifica, tornando a experiência do jogo mais verossimilhante e, portanto, mais crível.
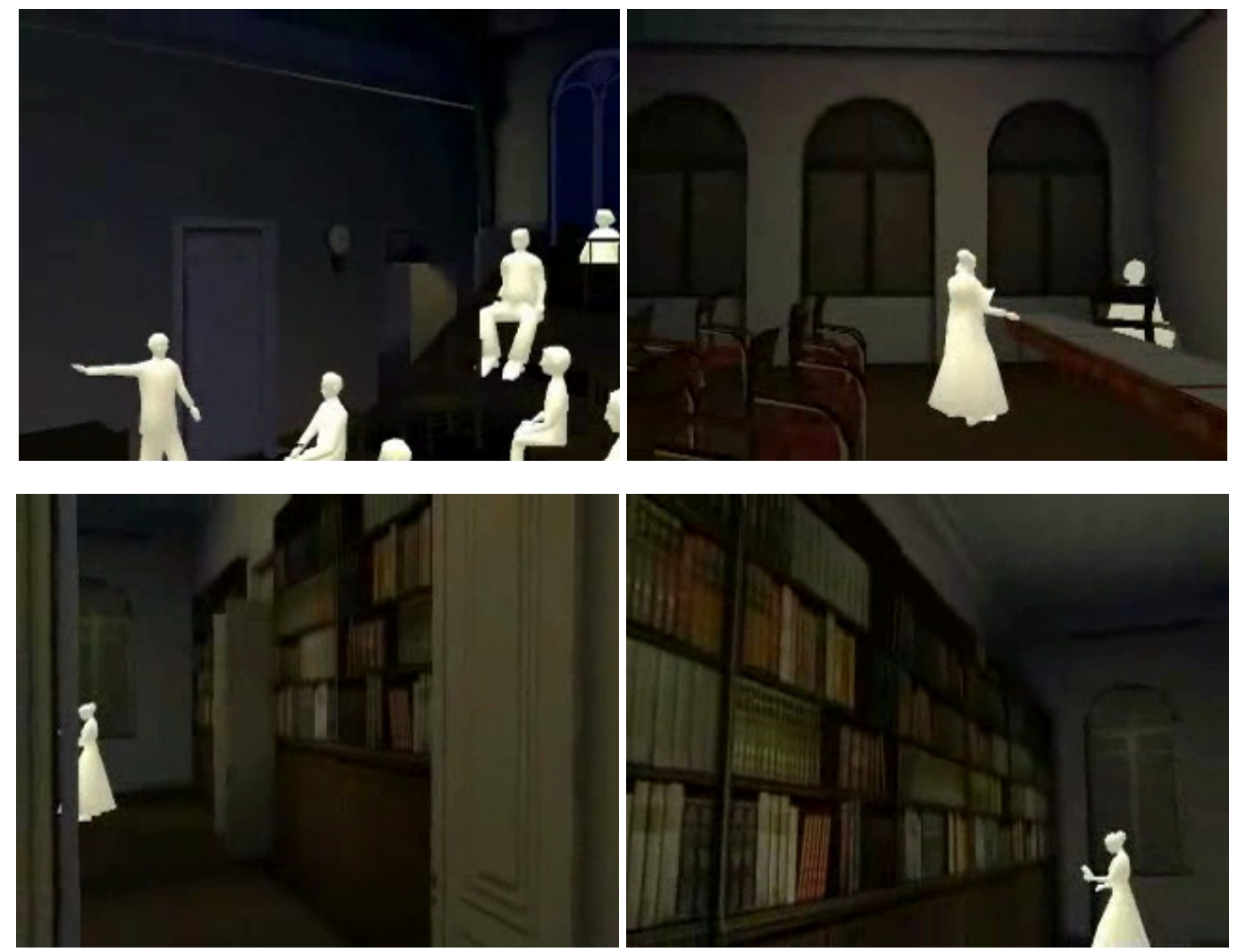

Ilustração 135 - Cozinheiro das Almas: ambientes sonorizados tridimensionalmente de acordo com o contexto e com personagens do cenário

Fonte: http://www.youtube.com/watch?v=fh4kDjTuLbY (Acesso em: 25 mar.2009) 
Vale ressaltar que a narrativa do jogo prevê uma aventura no tempo e no espaço e que, por uma questão estética e poética, a equipe de produção do jogo optou por apresentar todo o elenco de personagens coadjuvantes, presos no tempo e na lembrança, sem movimento ou cor. Além disso, ao se aproximar de tais personagens, o jogador ouve ruídos de conversa sem uma identificação clara de falas e conversas. Com isso, é criado um clima fantasmagórico, surreal e incômodo dentro de ambientes realistas.

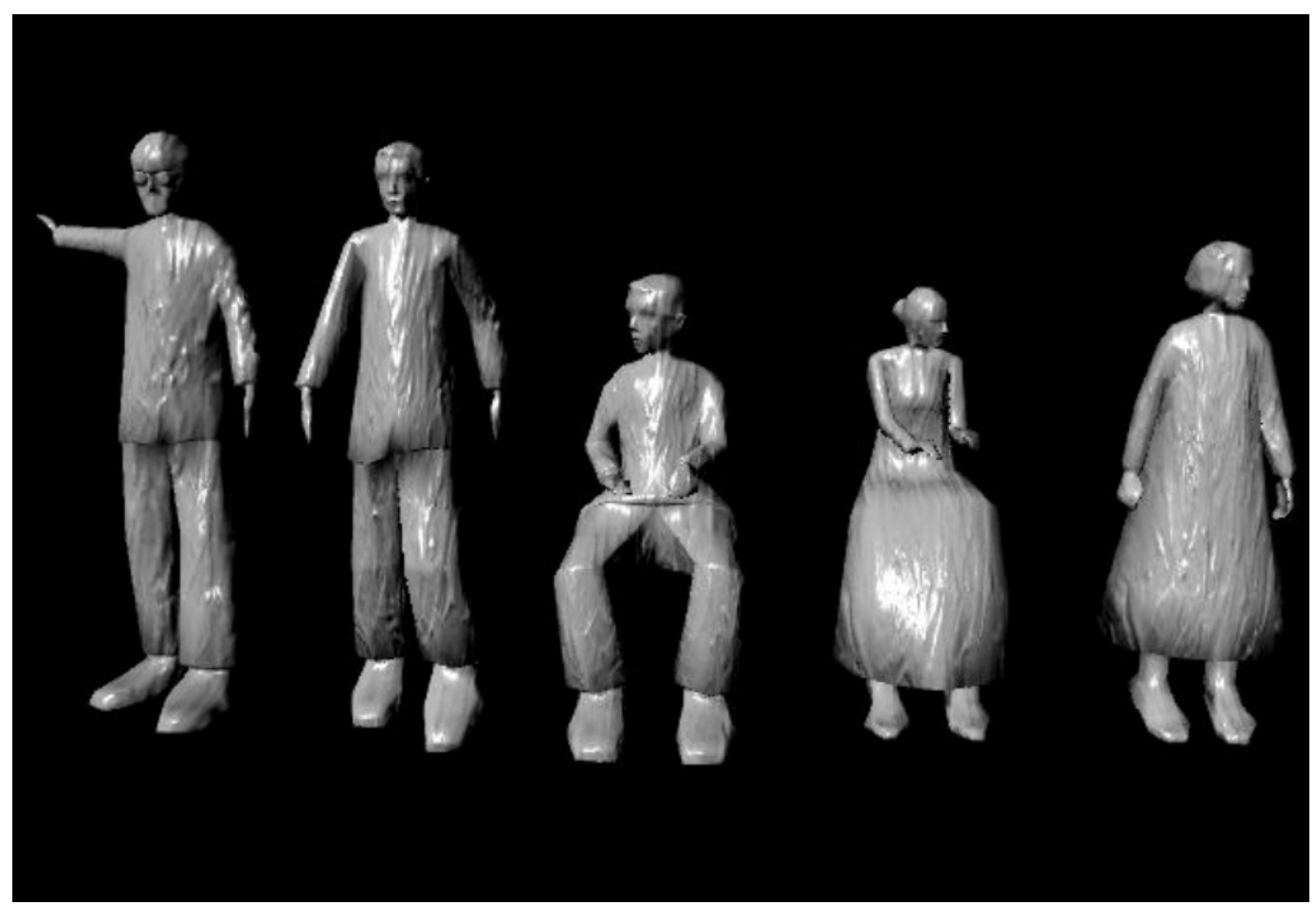

Ilustração 136 - Cozinheiro das Almas: personagens não controláveis

Fonte: http://www.cap.eca.usp.br/poeticas/?page_id=28 (Acesso em: 08 jan.2009)

\section{Reflexo e resposta}

Apesar de não ser um jogo de ação que exige respostas rápidas por parte do jogador, o Cozinheiro das Almas promove a interação entre teclado e mouse como forma de controle. As teclas direcionais do teclado movimentam o personagem principal enquanto o mouse controla o ângulo de visão desejado. Sem o controle integrado de ambos dispositivos, o jogador não consegue desenvolver a narrativa de explorar locais e momentos em interação com os ambientes. 


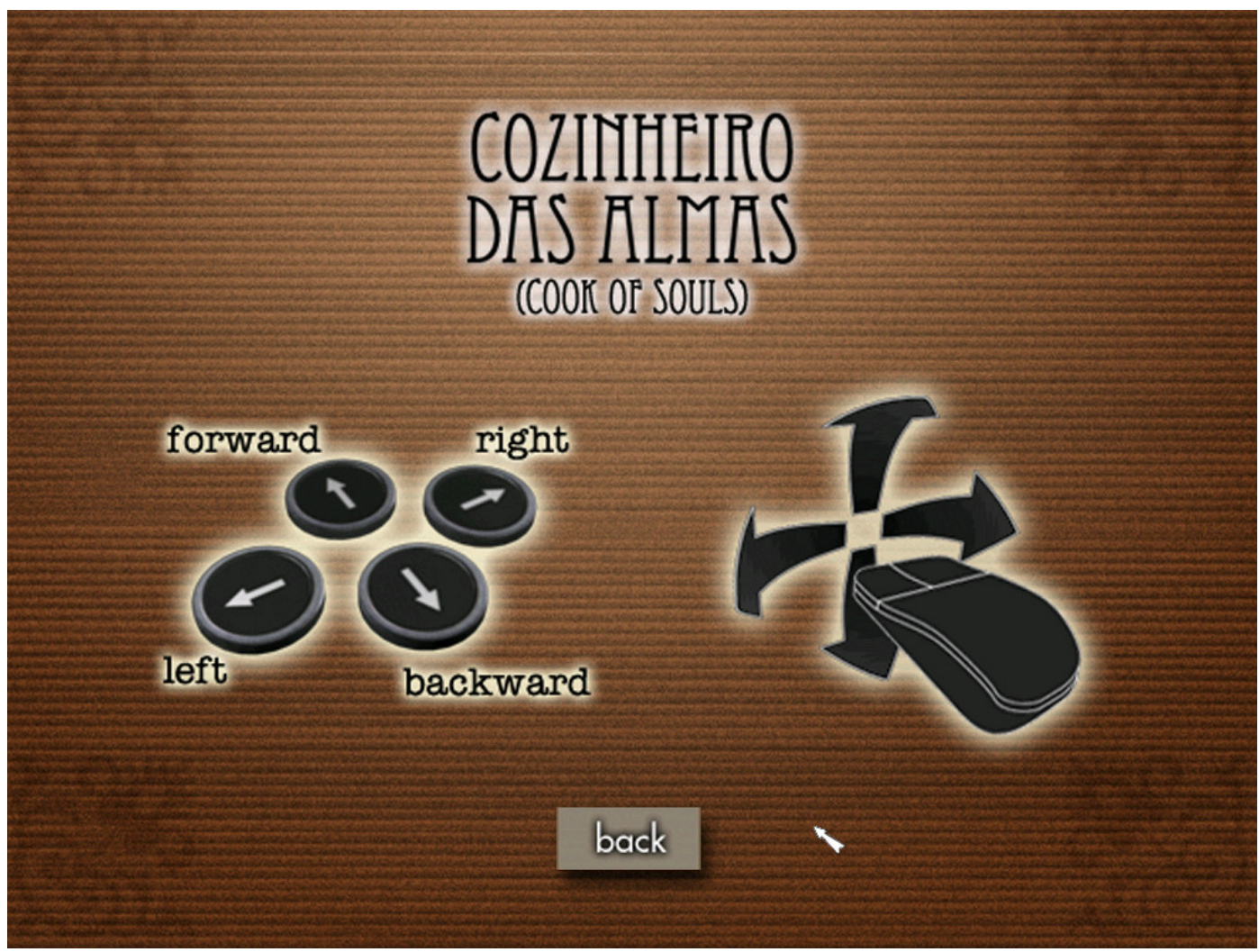

llustração 137 - Cozinheiro das Almas: tela de instrução da interface de controle Fonte: Produção própria (durante pesquisa exploratória do jogo)

Exatamente em interação com os diversos ambientes, o jogador encontra situações e elementos que compõem a narrativa do jogo para transportar o personagem principal ao longo dos espaços e do tempo. Dessa forma, coletâneas de objetos e texturas que auxiliam na criação verossímil dos ambientes e tempos para permitir a identificação visual imediata da tal narrativa baseada no labirinto temporal e espacial proposto.
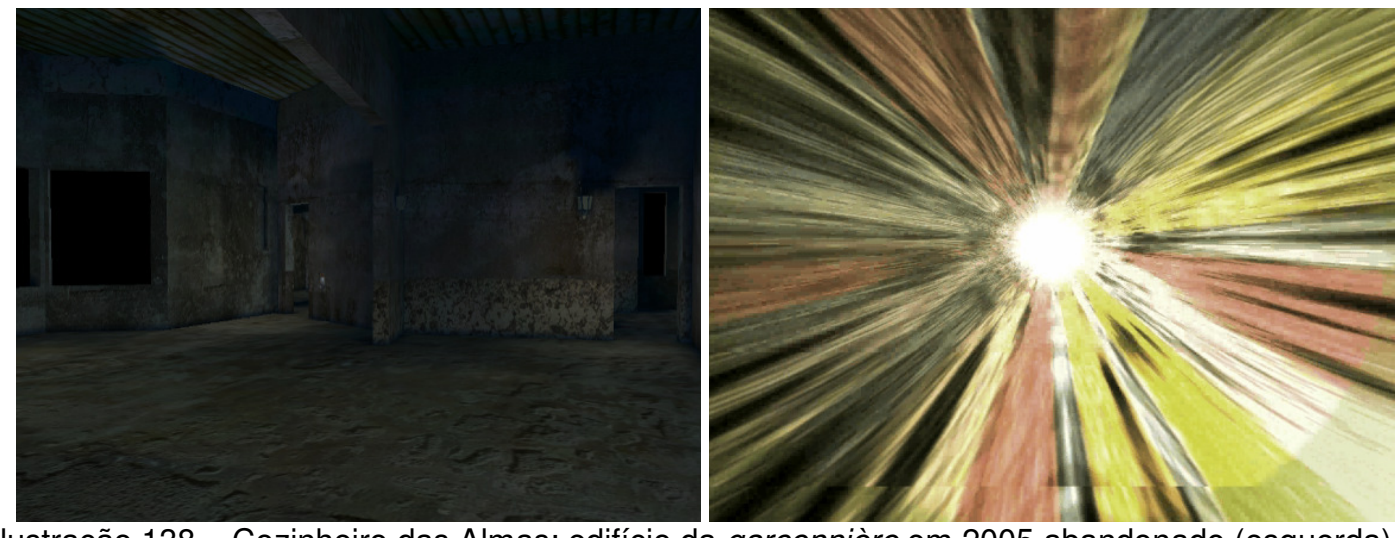

Ilustração 138 - Cozinheiro das Almas: edifício da garçonnière em 2005 abandonado (esquerda) e "túnel do tempo" (direita)

Fonte: Produção própria (durante pesquisa exploratória do jogo) 


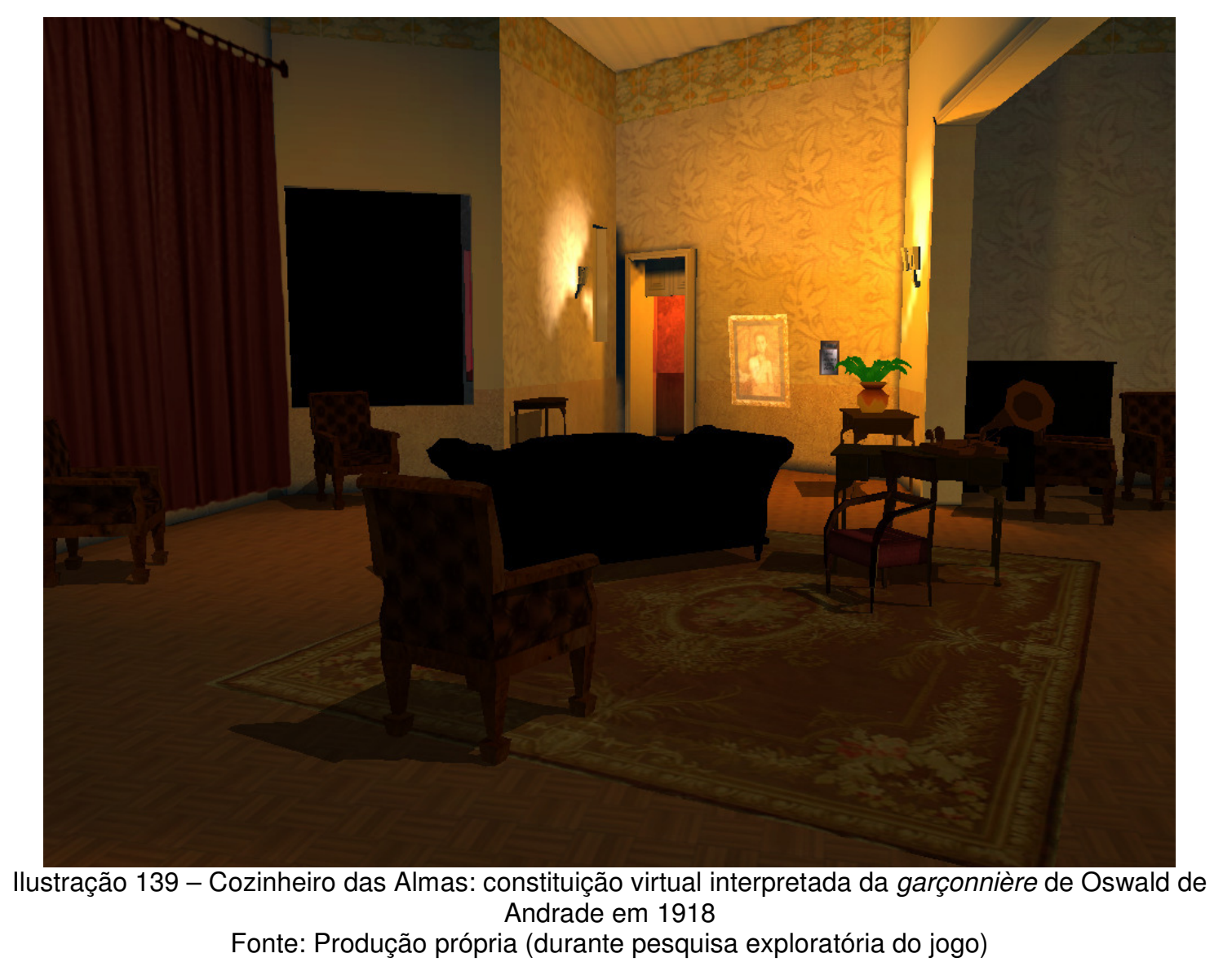

\section{Conteúdo informacional}

Como plataforma de repasse de conteúdo e informação, o Cozinheiro das Almas parte do pressuposto da obra de Oswald incentivando que o jogador procure saber mais da obra referenciada, "O Perfeito Cozinheiro das Almas deste Mundo", das demais obras do autor e de sua biografia. Além disso, o jogo explora esteticamente as referências do diário

Para criar a atmosfera caótica de um labirinto que explora espaços e tempos de São Paulo, conduzindo o jogador em ambientações que, pelos elementos visuais, apresentam o esforço da equipe em relação às pesquisas históricas e fidelidade com aspectos das diversas épocas. E assim, criando uma ambientação de época, o jogo promove a assimilação da composição arquitetônica e, portanto, cotidiana de momentos passados, inclusive vivenciando um contato estético com diversas culturas. 


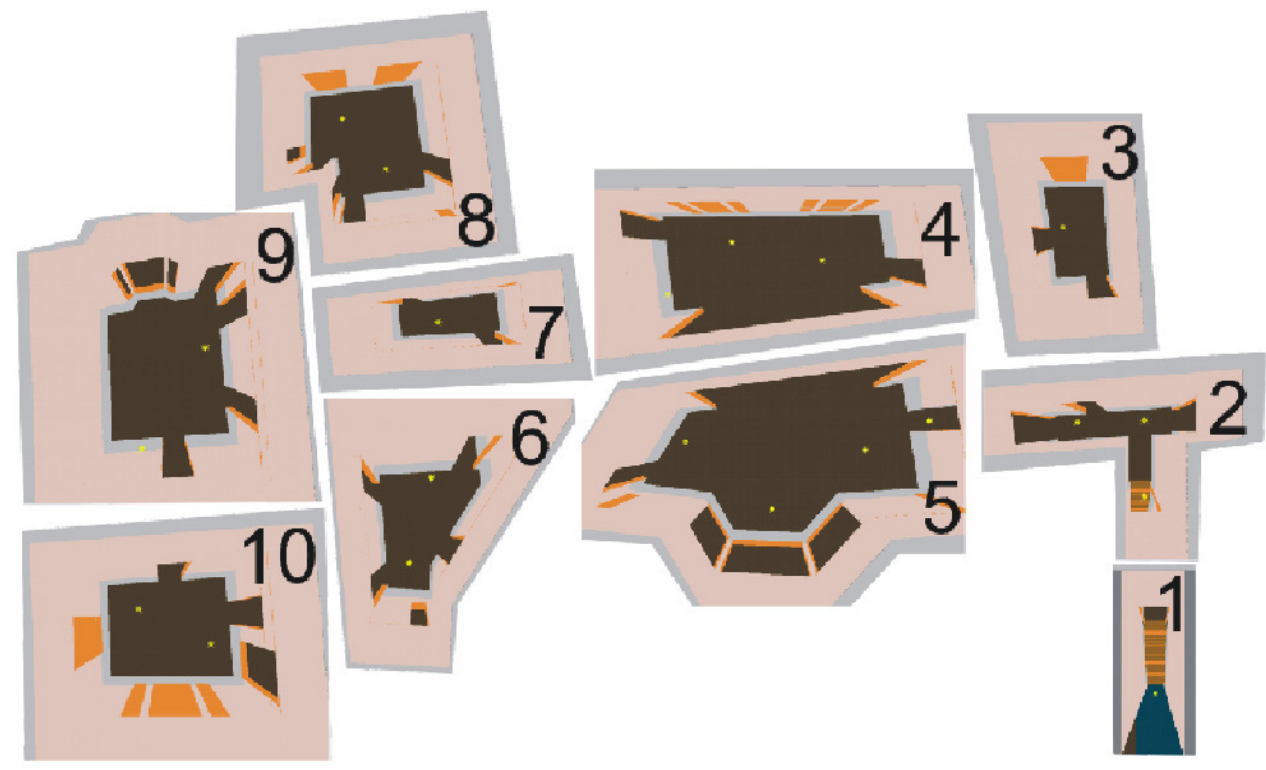

Ilustração 140 - Cozinheiro das Almas: esquema da planta da garçonnière Fonte: http://www.cap.eca.usp.br/poeticas/?page_id=28 (Acesso em: 08 jan.2009)

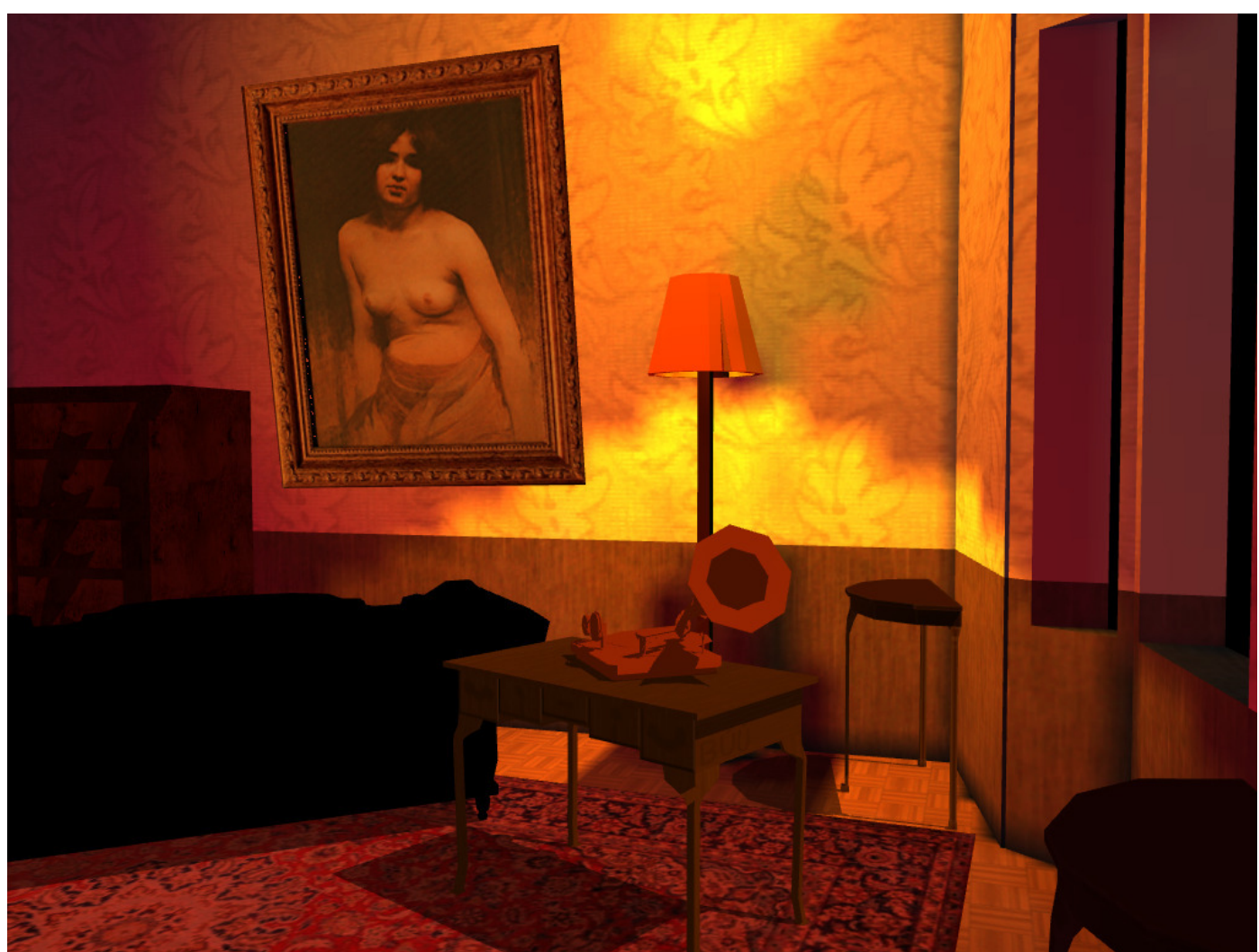

Ilustração 141 - Cozinheiro das Almas: detalhe da garçonnière de 1918 Fonte: Produção própria (durante pesquisa exploratória do jogo) 


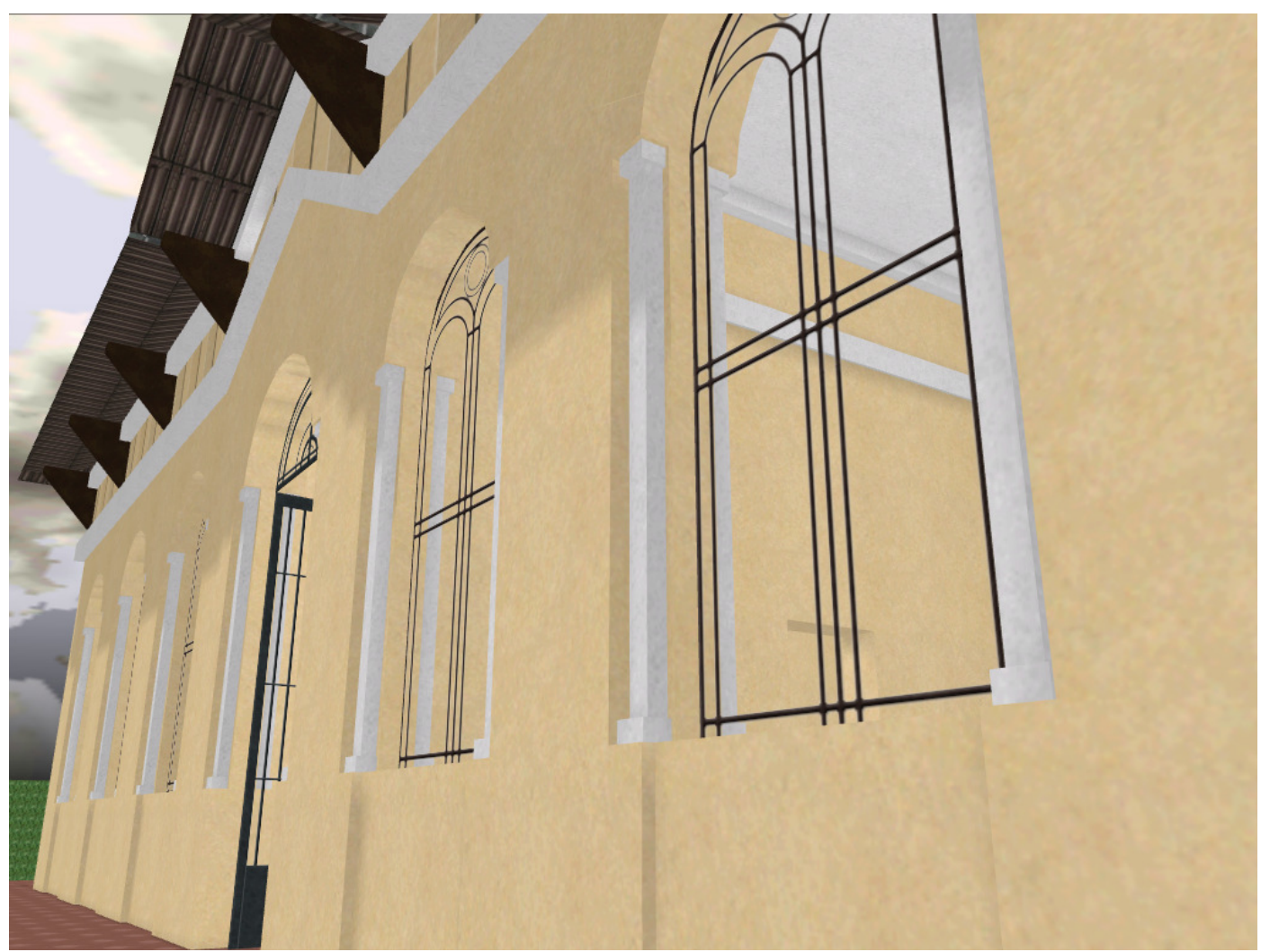

Ilustração 142 - Cozinheiro das Almas: entrada de um dos edifícios da Escola Normal Fonte: Produção própria (durante pesquisa exploratória do jogo)

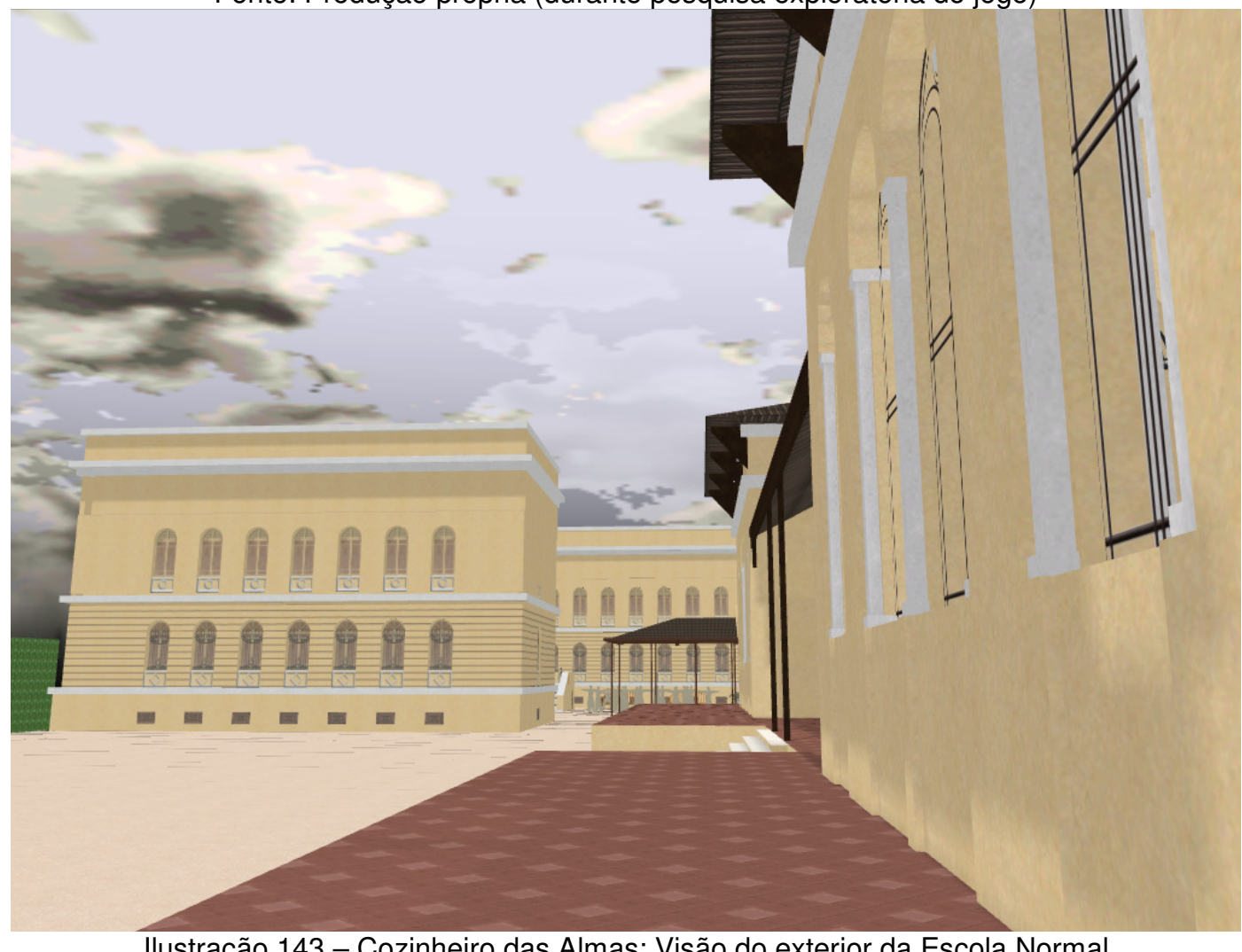

Ilustração 143 - Cozinheiro das Almas: Visão do exterior da Escola Normal Fonte: Produção própria (durante pesquisa exploratória do jogo) 


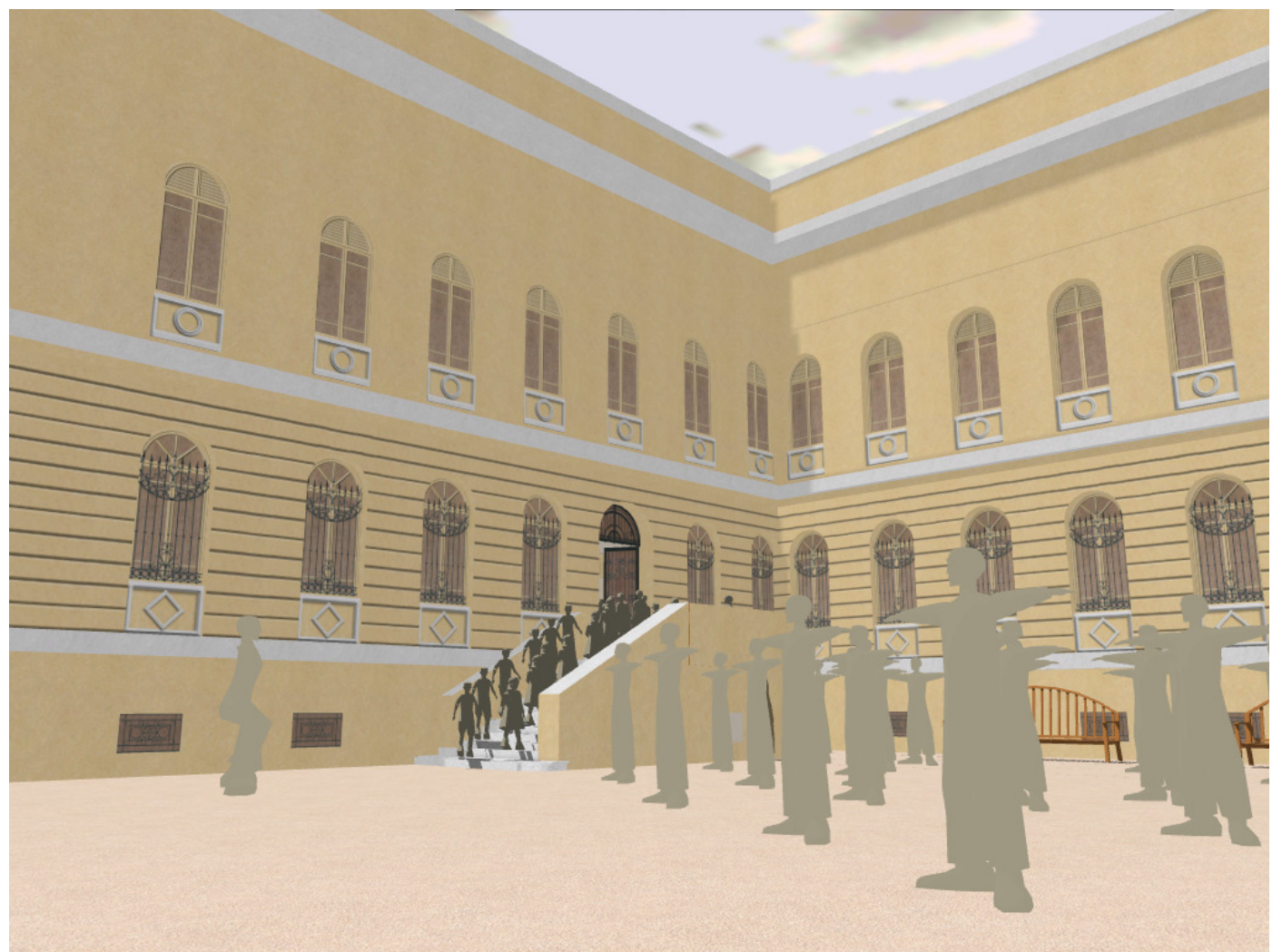

Ilustração 144 - Cozinheiro das Almas: pátio da Escola Normal com personagens Fonte: Produção própria (durante pesquisa exploratória do jogo)

\subsection{4 - Conclusão}

\section{Peculiaridades}

O jogo é único não só por ser fundamentalmente um projeto experimental acadêmico, mas pela própria linguagem de não-jogo onde a vivência do jogador é explorada e incentivada superando as propostas comuns de um game, onde existem objetivos e desafios claros, premiações e castigos imediatos e intuitivos. O Cozinheiro das Almas desloca o jogador no espaço e no tempo sem que ele tenha qualquer informação artificial do software sobre seus objetivos, desafios, possíveis inimigos ou limite de tempo. Simplesmente o jogador se apresenta em espaços e tempos que se alternam mediante ações que involuntariamente transportam o jogador para outro lugar e/ou espaço.

Da mesma forma, a tela apresenta a visão do jogador sem qualquer interferência do HUD (Head-Up Display) ou GUI (Graphical User Interface), que são os ícones e gráficos fixos da tela que informam o nível de vida, energia, missões a 
realizar, mapa do ambiente, etc. O jogador está completamente à mercê dos seus movimentos, sem qualquer tipo de guia, ajuda ou inteligência artificial para conduzilo em uma narrativa linear. Assim como o desenvolvimento do jogo partiu de um pressuposto de projeto experimental, o jogador tem a oportunidade de experimentar uma vivência de imersão virtual digital de forma livre e caótica ao mesmo tempo.

Reforçando essa idéia, o jogo não permite que se salve o progresso como é comum em qualquer game comercial. Cada jogo promove uma experimentação diversa e única dentro de uma programação pré-determinada como cada dia é único dentro do cotidiano.

\section{Percepções do jogo}

$O$ jogo parte do desenvolvimento de uma linguagem digital interativa e imersiva em diversos cenários temporais de São Paulo. Assim, o "Cozinheiro das Almas" conjuga a linguagem digital com o processo educativo no elemento lúdico do jogo em duas vertentes: primeiramente através do processo de desenvolvimento de um jogo, onde são exigidas a elaboração criativa e artística de modelos, cenários e texturas além da composição de linhas de códigos e programação; segundo, pelo impacto que o jogador tem com diversos ambientes de época de São Paulo, ao longo do século $\mathrm{XX}$, que o faz assimilar os aspectos estéticos de diferentes espaços em diferentes momentos, além do desvendamento do quebra-cabeça temporal e espacial proposto pelo jogo.

Ainda por se tratar de uma produção realizada por um grupo acadêmico de pesquisa, o jogo se torna uma experiência evidente do potencial educativo de um produto digital lúdico no processo de sua composição que, no caso, ainda ressalta o trabalho coletivo e multidisciplinar, com trocas e compartilhamentos de competências individuais para alcançar um resultado benéfico para todos os envolvidos. 


\section{7 - Análise sobre o Blender}

\subsection{1 - Dados gerais}

\begin{tabular}{|l|l|}
\hline Nome & Blender 2.48a \\
\hline Plataforma/ console & Software para computador (Linux/Windows/ MAC) \\
\hline Desenvolvimento & $\begin{array}{l}\text { Blender Foundation (org), desenvolvimento coletivo } \\
\text { pela lógica open source }\end{array}$ \\
\hline Distribuição & Gratuito para download \\
\hline Classificação etária & Todas as idades \\
\hline Data de lançamento & Outubro de 2008 (mundial) \\
\hline Site oficial & http://www.blender.org/ \\
\hline
\end{tabular}

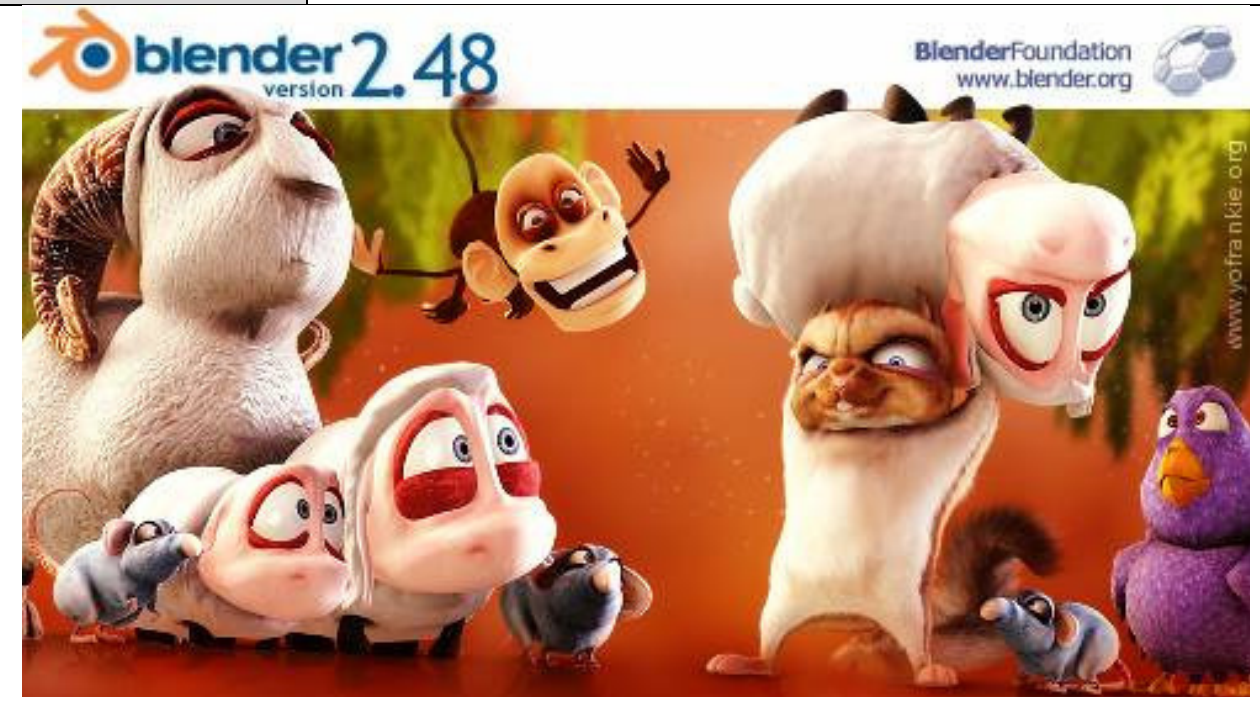

Ilustração 145 - Tela de entrada do Blender

Fonte: http://www.blender.org/ (Acesso em: 08 jan.2009)

\subsection{2 - Design e Estrutura}

\begin{tabular}{|l|l|}
\hline \multirow{2}{*}{ Gênero } & $\begin{array}{l}\text { A lógica de game implícita no Blender permite a } \\
\text { elaboração de todos os gêneros de game. No entanto, } \\
\text { o mais usual é desenvolver jogos de Ação e } \\
\text { Adventure, ou seja, jogos em tempo real que exigem } \\
\text { velocidade e solução de enigmas. }\end{array}$ \\
\hline $\begin{array}{l}\text { Interfaces } \\
\text { Jogabilidade }\end{array}$ & $\begin{array}{l}\text { No processo de elaboração de um jogo (etapa de } \\
\text { modelagem, texturização, programação e compilação), } \\
\text { é possível utilizar teclado (através de comandos e e }\end{array}$ \\
\hline
\end{tabular}




\begin{tabular}{|l|l|}
\hline teclas de atalho) e mouse (através da movimentação \\
precisa e por ativação de botões) e até mesa \\
digitalizadora (tablet que substitui o mouse) em \\
interface com o monitor que pode ser dividido em \\
várias telas de visualização e edição de malha, \\
textura, animação, controladores, etc. O jogo \\
elaborado pode ser controlado por meio do teclado e \\
mouse, utilizando o monitor e as caixas de som para \\
saída de vídeo e áudio. \\
\hline Objetivos
\end{tabular}


base no software. Propriamente sobre a lógica de game embutida no software, várias implementações e aprimoramentos aumentaram o potencial do software na produção de jogos, a maioria gratuitos e voltados para os sistemas operacionais baseados em Linux.

\subsection{3 - Aspectos de formação}

Para fazer uma análise do Blender ressaltando os aspectos de interesse a essa dissertação, optou-se pelo desenvolvimento de um game simples, que explorasse algumas potencialidades do software, tentando aliar ludicidade e processo de aprendizagem. Essa experiência de criação e desenvolvimento serve de base para a descrição dos aspectos de formação possíveis no envolvimento do usuário com o software.

O jogo elaborado tem o nome fantasia de "PacMim" e se encontra no CD, que acompanha a dissertação. É composto pelo personagem principal, o PacMim (Acesso em: referência ao clássico Pacman, adicionando o termo "mim" do português, por se tratar de uma auto-referência), um cenário fechado, picolés a serem colecionados e um fantasma inimigo que deve ser evitado. No jogo só existe uma fase e foi elaborado para fins exclusivamente acadêmicos.

\section{Ativação sensorial}

A tela de modelagem do Blender ativa a nossa percepção de profundidade, mesmo que impressa no monitor do computador, ou seja, simula a tridimensionalidade em um plano bidimensional. Interagindo com o mouse nas funções de movimentação rotacional, translacional e de aproximação, o usuário tem total uma completa sensação de espacialidade e pode, então, interagir com as malhas e modelos em 3D. Exige, portanto a completa interação entre visualização e interação de movimentação no espaço. 


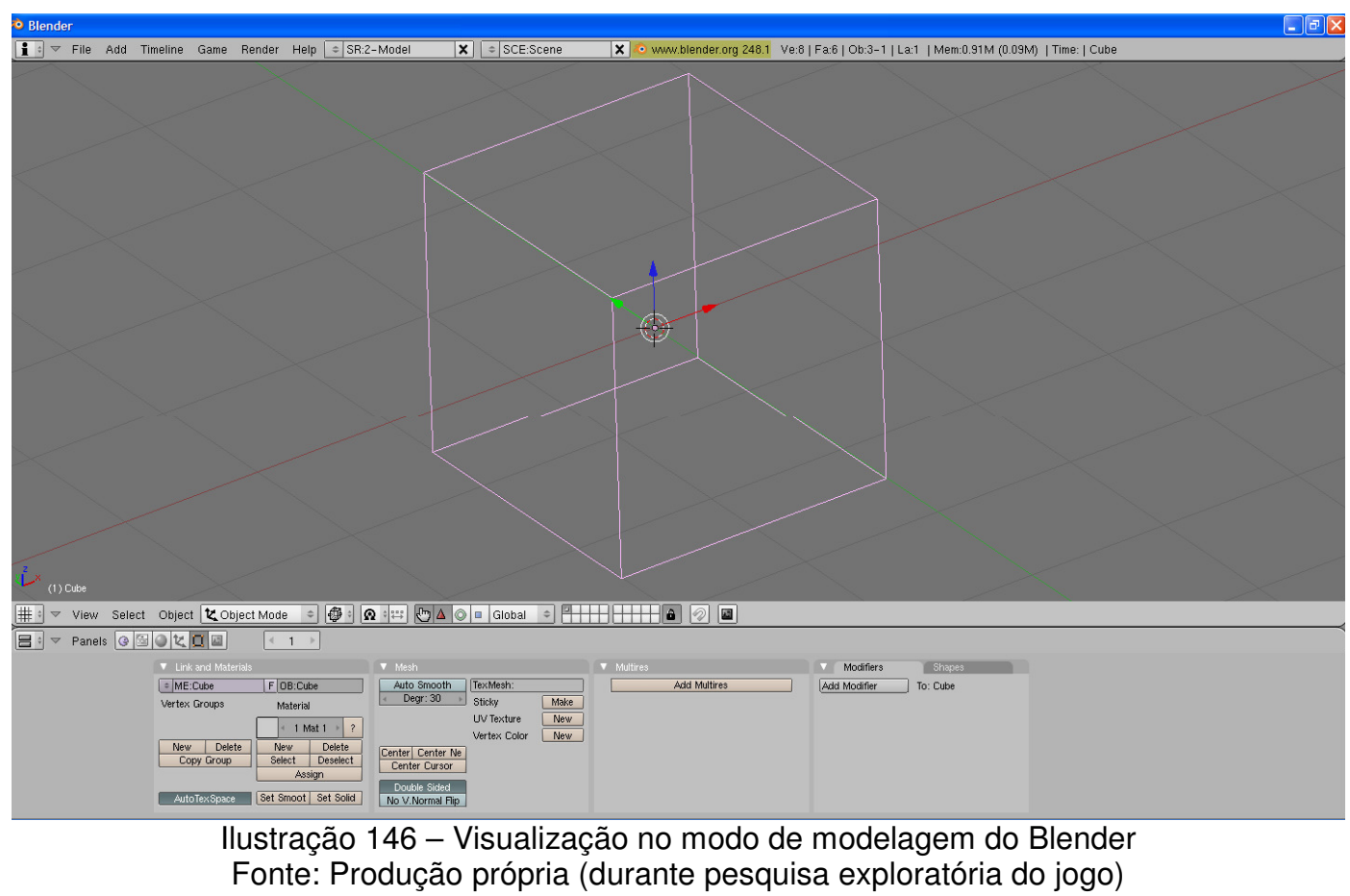

No processo de modelagem, é exatamente a noção espacial e tridimensional que é mais exigido do usuário para a compreensão dos passos da composição e modelagem. No caso, além de utilizar espelhos e fotos, são utilizados desenhos em poses fechadas (frontal e lateral) para auxiliar no processo de modelagem do personagem principal.

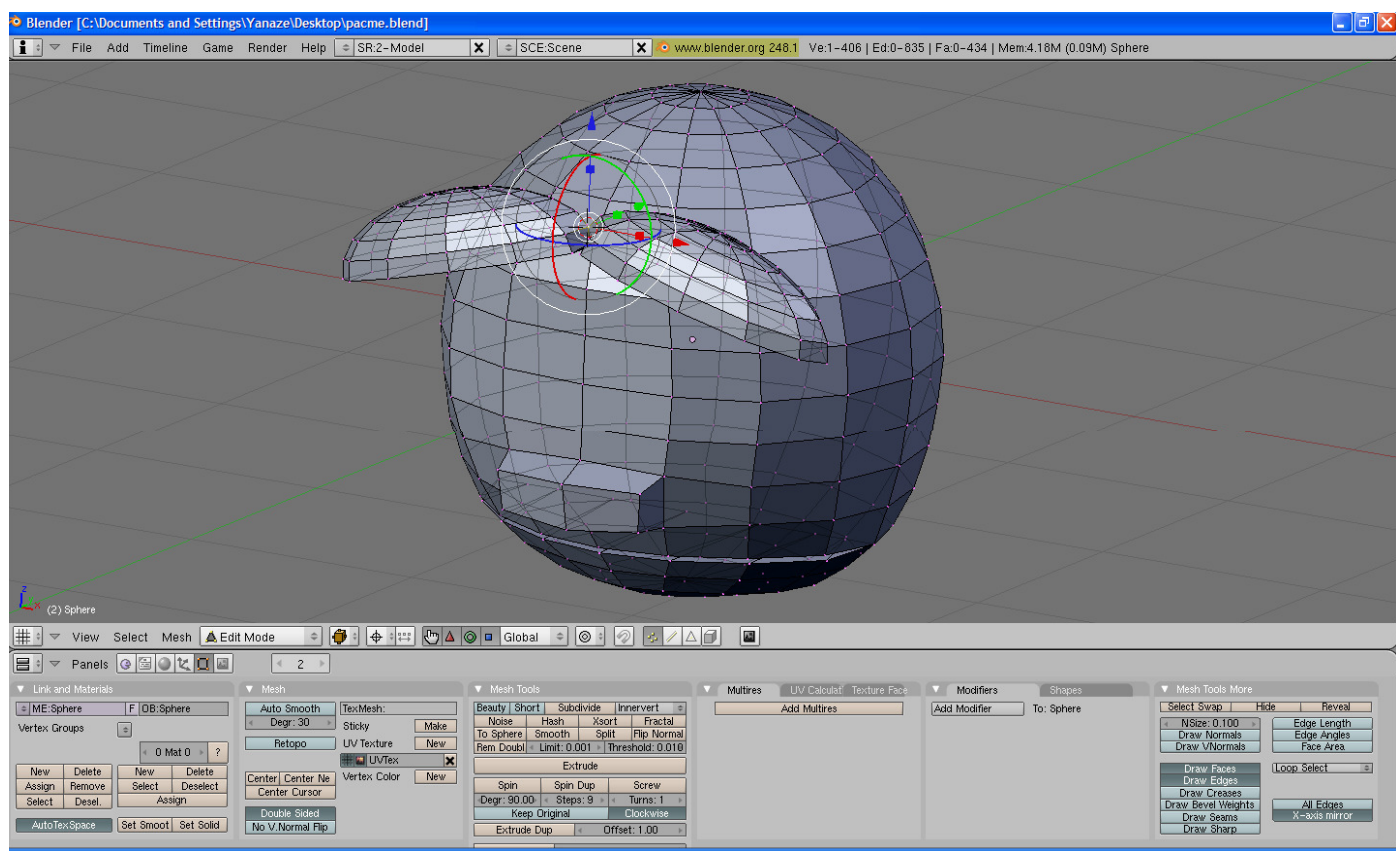



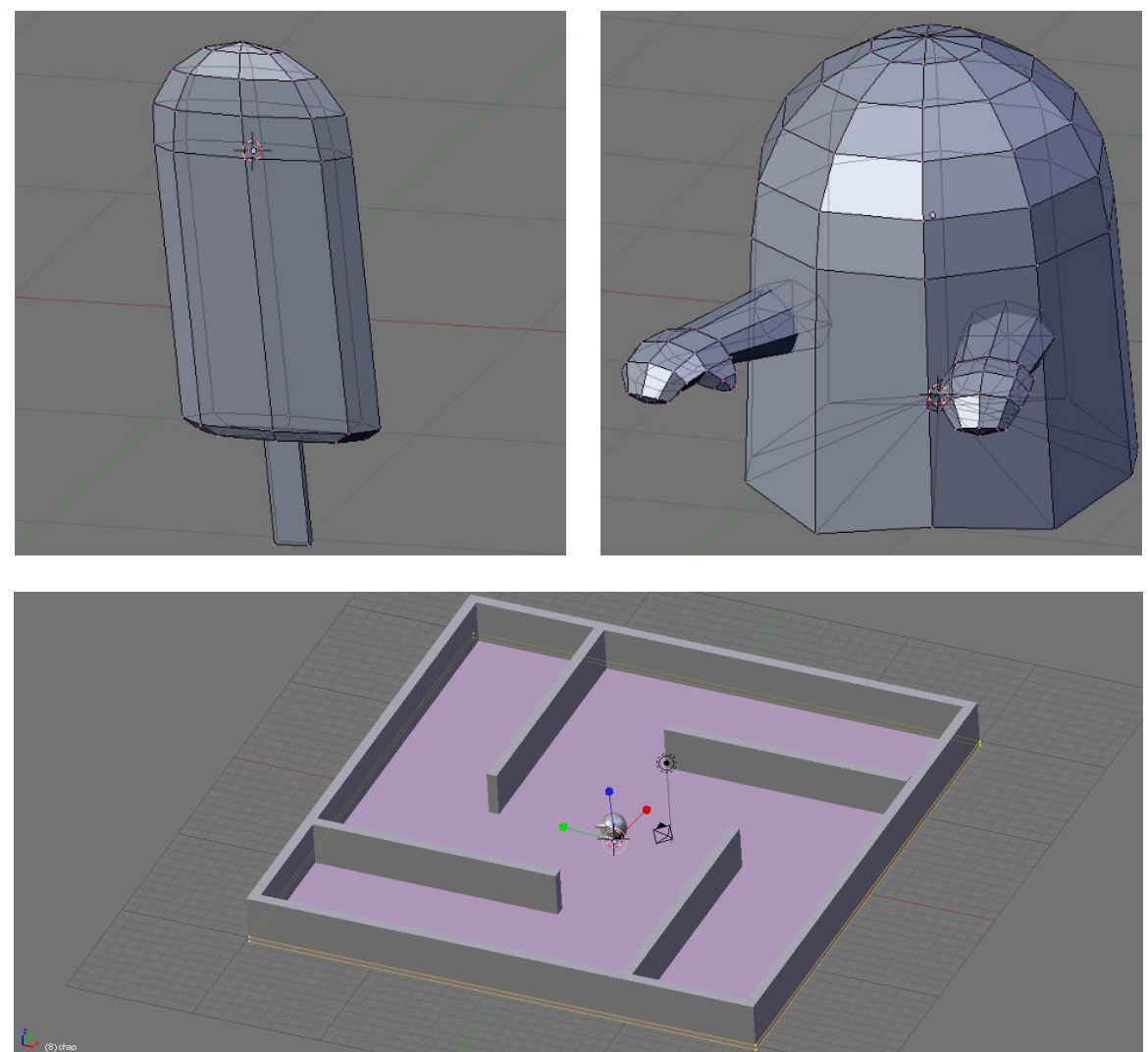

llustração 147 - Processo de modelagem do personagem principal "PacMim", da comida (picolé), do inimigo (fantasma) e do cenário

Fonte: Produção própria (durante pesquisa exploratória do jogo)

No processo de texturização, a ativação da memória visual no processo artístico de compor as imagens que fazem parte de modelos, personagens e cenários se torna essencial para criar a sensação de verossimilhança e, então, de empatia e aceitação do contexto geral do game. 


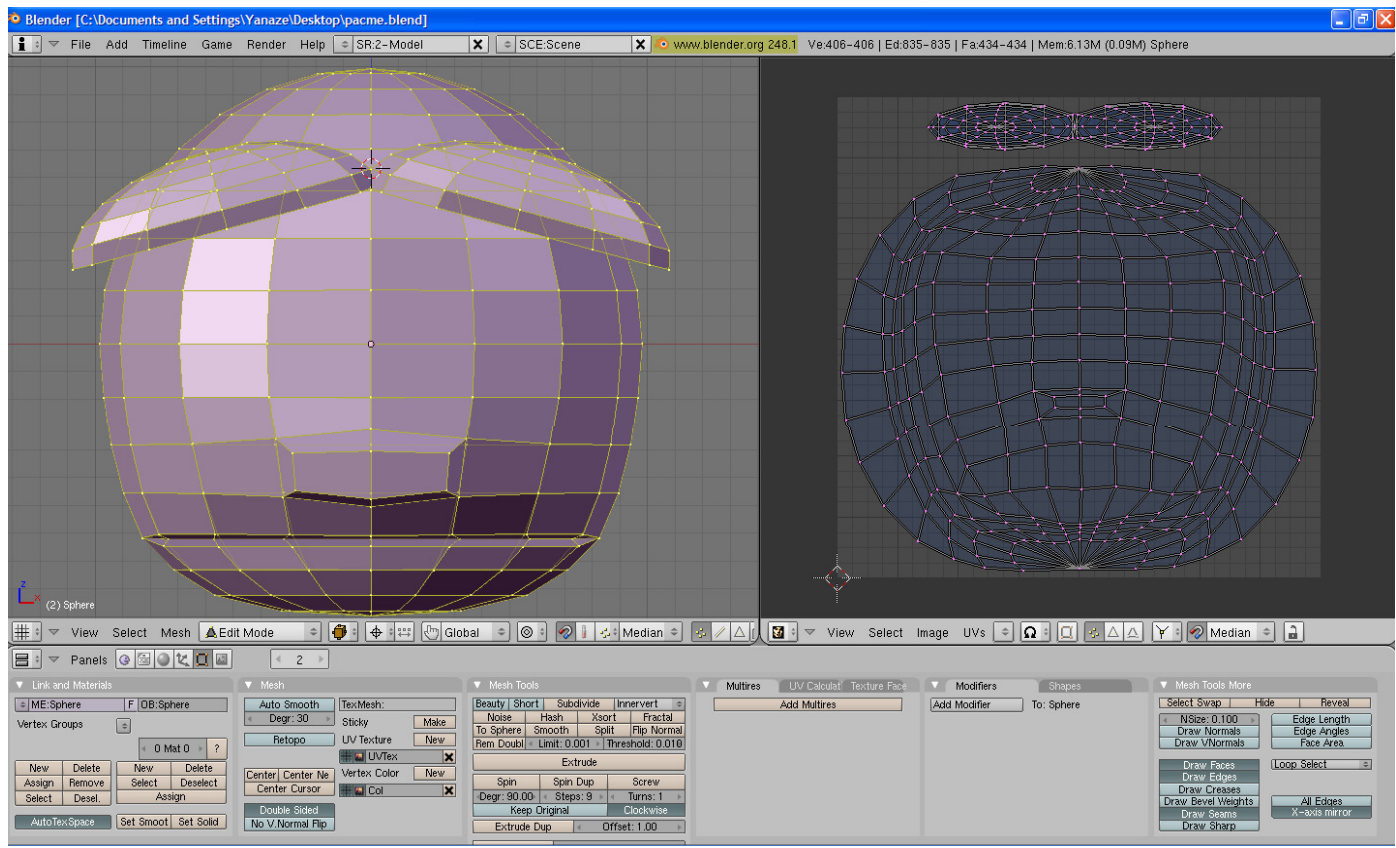

llustração 148 - Processo de abrir a malha para a texturização do personagem principal do "PacMim" Fonte: Produção própria (durante pesquisa exploratória do jogo)

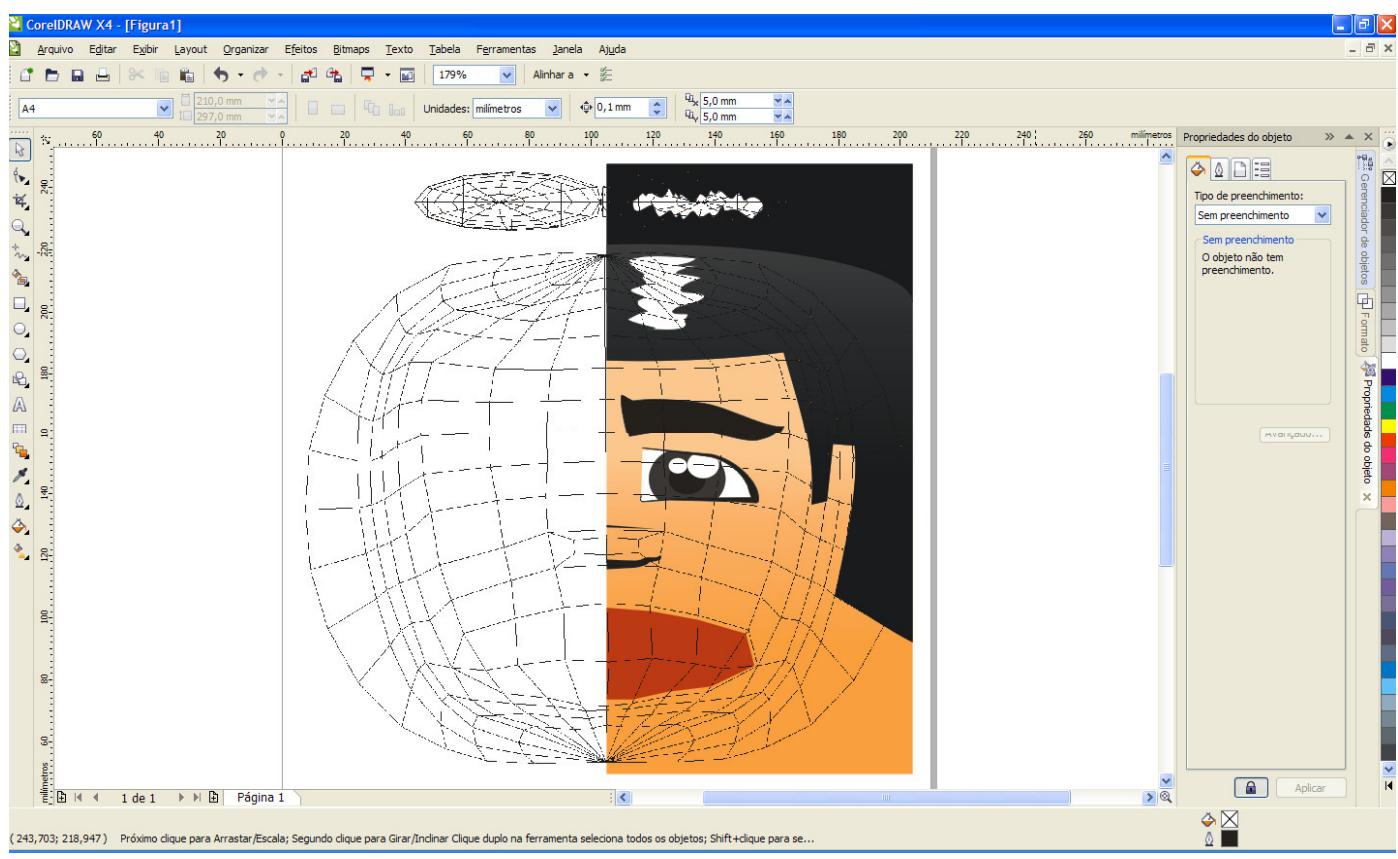

Ilustração 149 - Texturização do personagem principal do "PacMim" sobre a malha aberta Fonte: Produção própria (durante pesquisa exploratória do jogo) 

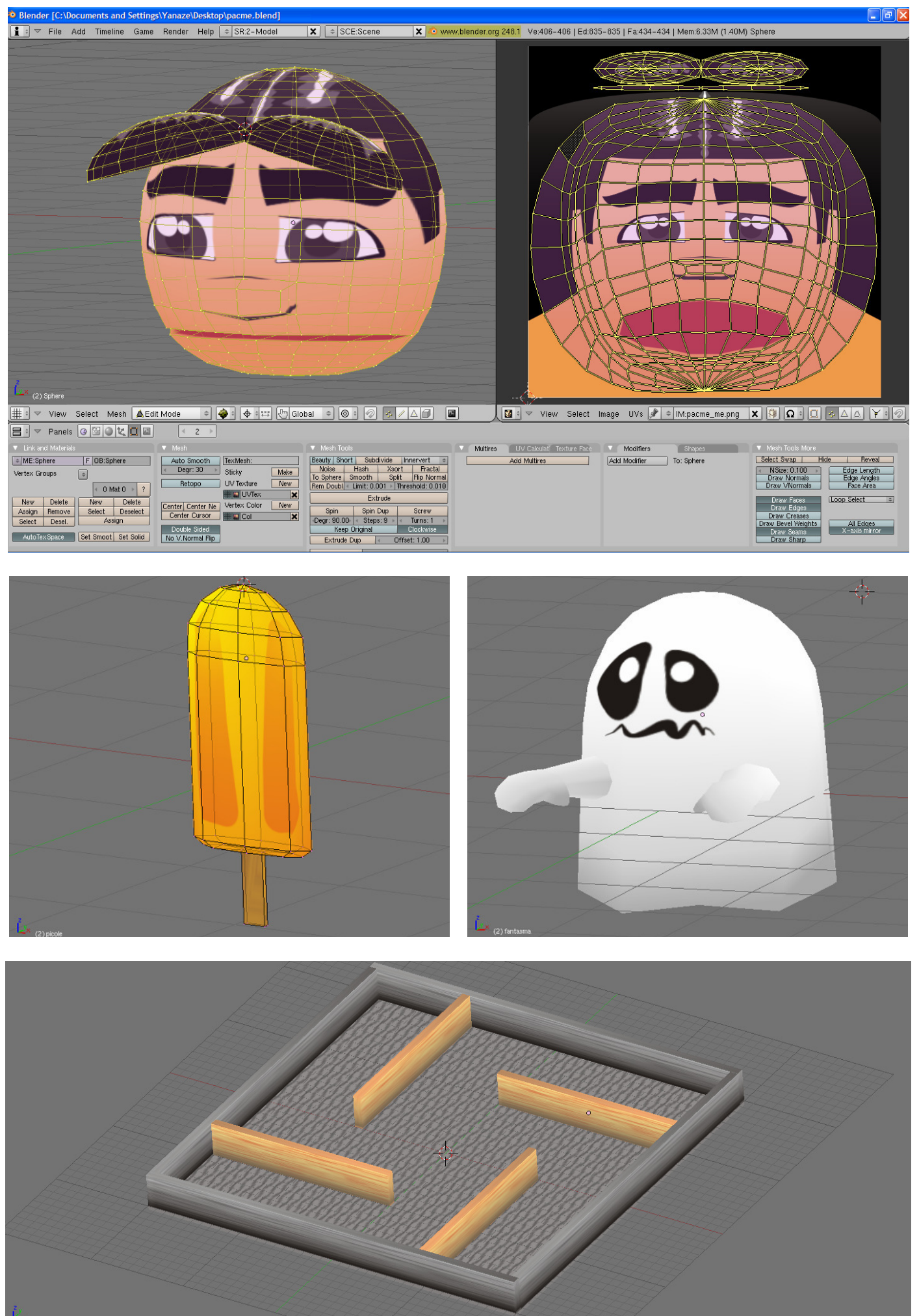

Ilustração 150 - Aplicando a textura no personagem principal “PacMim”, na comida (picolé), no inimigo (fantasma) e no cenário

Fonte: Produção própria (durante pesquisa exploratória do jogo) 
No processo de animação é importante ativar a memória cinética de movimentação, sobretudo dos personagens, para, mais uma vez, garantir a sensação de verossimilhança, empatia e aceitação dos avatares por parte do jogador.
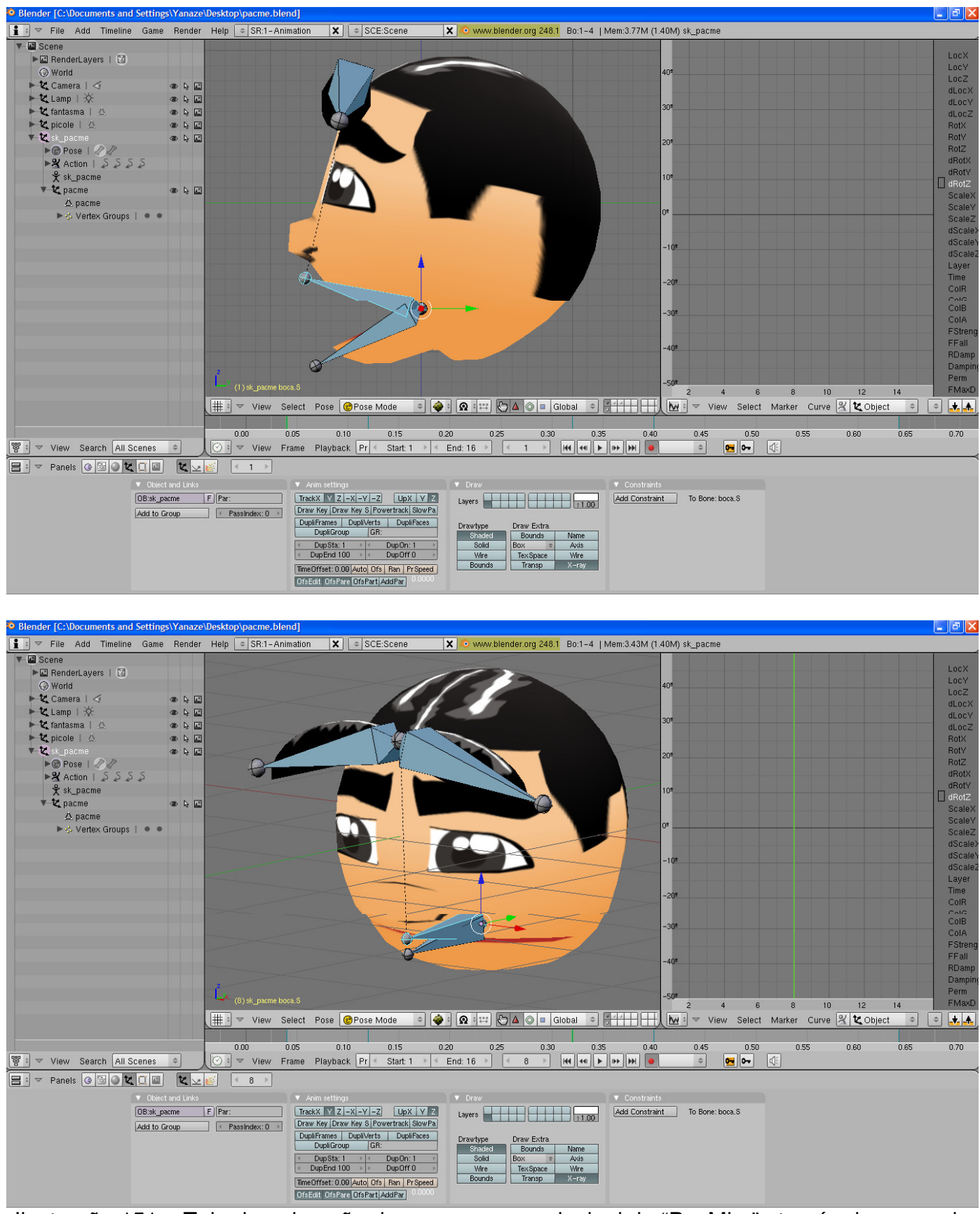

llustração 151 - Tela de animação do personagem principal do "PacMim" através de ossos de controle pela timeline

Fonte: Produção própria (durante pesquisa exploratória do jogo) 
No processo de programação, como o Blender conta com um sistema visual para compor, controlar e integrar trechos de comandos, o usuário ativa muito da lógica visual e intuitiva para desenvolver a inteligência artificial responsável pelo funcionamento do game. Para tanto, o usuário interage através de conectores de blocos lógicos.

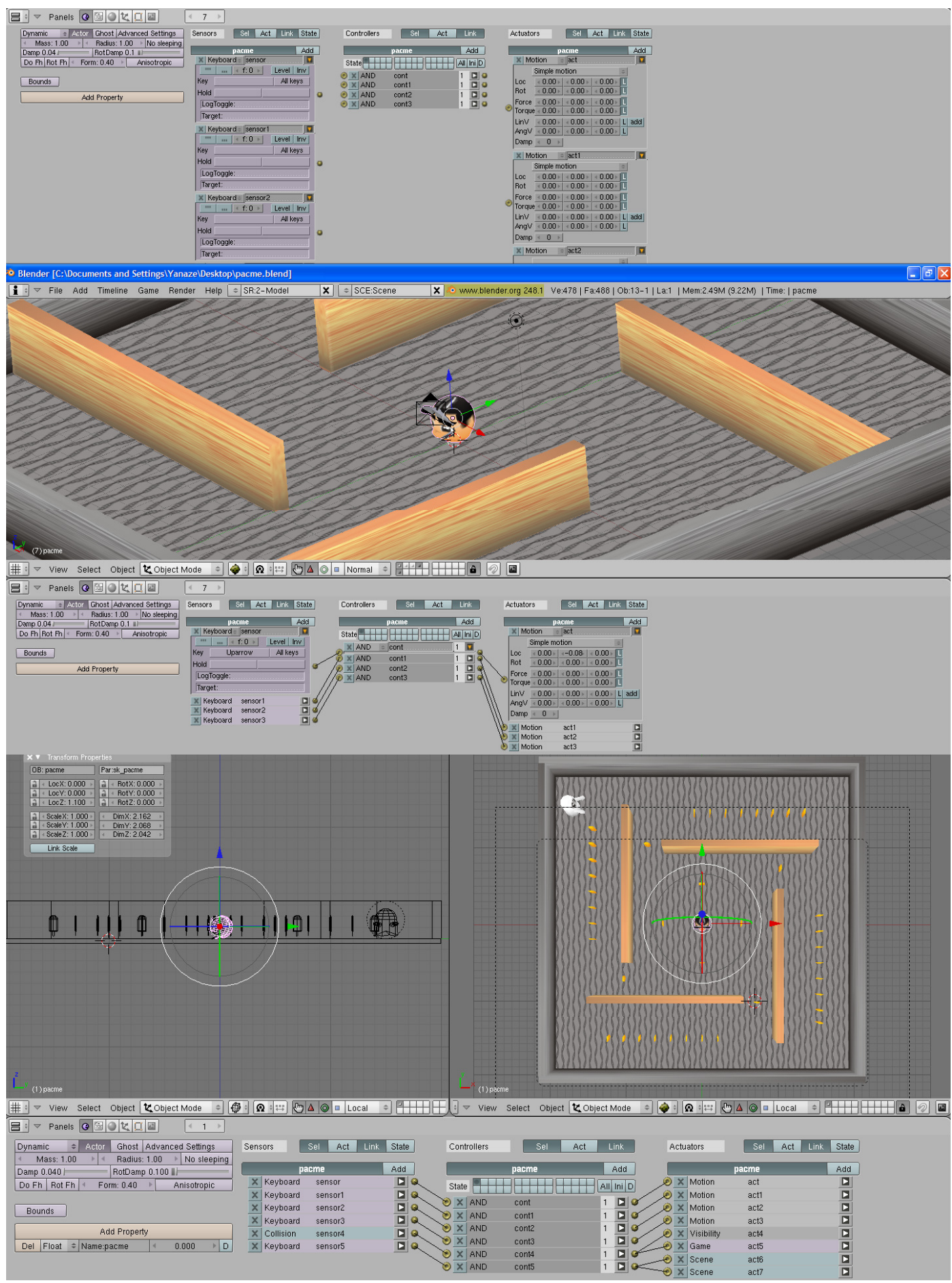

Ilustração 152 - Tela visual de programação do "PacMim" com blocos lógicos Fonte: Produção própria (durante pesquisa exploratória do jogo) 


\section{Reflexo e resposta}

No processo de modelagem, constantemente é necessário olhar a malha (personagem, objeto ou cenário) por vários ângulos, inclusive, "girando" a visualização para verificar a existência de erros e problemas do modelo. Portanto, ao mesmo tempo em que o modelador se atenta e ativa a sua noção de espacialidade $e$ tridimensionalidade, deve também responder aos possíveis erros e problemas da malha.

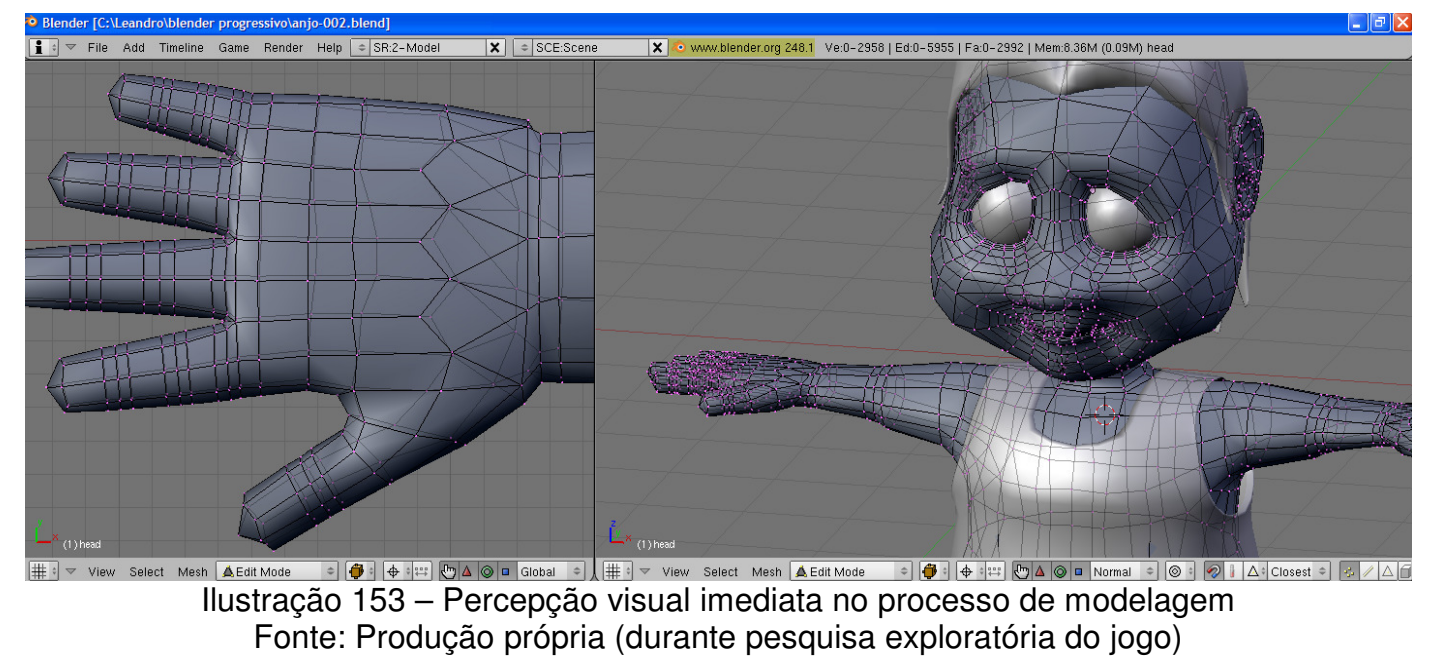

No processo de animação, também ocorrem diversos testes para a verificação de erros. Dessa forma, pode se contar com o reflexo do usuário para detectar problemas e modificar a animação.

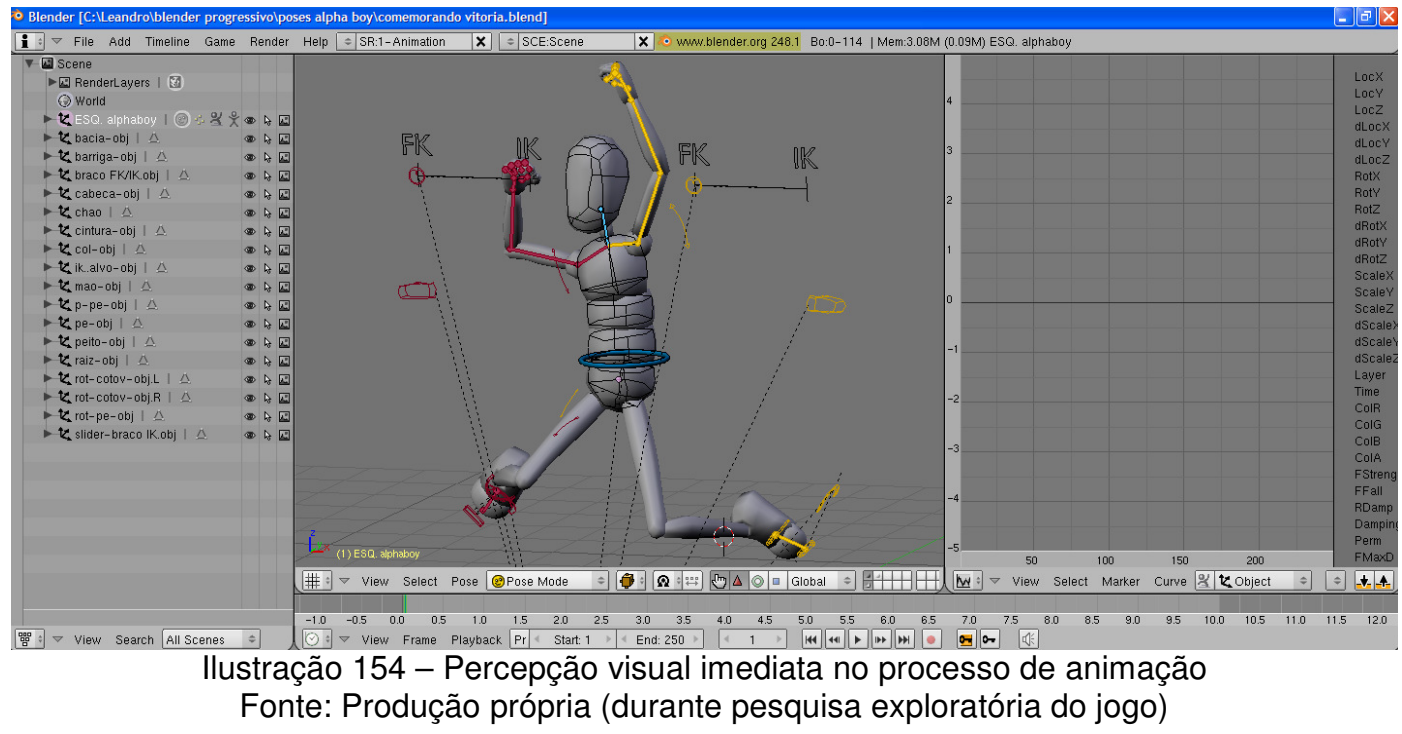




\section{Conteúdo informacional}

O principal ganho em termos de conteúdo e informação acontece no processo de auto-aprendizagem (a heutagogia já discutida no capítulo 2 da dissertação) valendo-se, principalmente da conexão de inteligência existente nos fóruns de discussão, plataforma wiki, artigos, tutoriais, manuais e aulas existentes sobre o Blender. As fontes são incontáveis e muitas produções são disponibilizadas livre e gratuitamente para a compreensão de conceitos e aplicações que são aproveitados nos projetos de outras pessoas.

Os usuários de Blender, seguindo o exemplo dos desenvolvedores, também são extremamente solidários em relação à sua produção. Existem exemplos de estúdios que estão utilizando o Blender para produzir longas e curta-metragens de animação que disponibilizam os arquivos originais utilizados na produção para que os demais usuários possam estudar as técnicas e conceitos empregados profissionalmente. A lógica do poder da informação é alterada na realidade dos softwares e produções digitais abertas: quem abre mão da exclusividade da informação e que, portanto, na lógica capitalista, está perdendo poder, na lógica hacker (já discutida no capítulo 2) tem o ganho de estar envolvido com outros usuários que também compartilham seus conhecimentos, sendo beneficiado por essa relação.

Nada é de graça, pois na lógica do software livre e também na do Blender, programadores e usuários contribuem com um pouco do seu tempo e experiência (esse é o preço) e recebem de volta um programa funcional inteiro (esse é o produto). O Blender é exemplo claro da eficiência dessa lógica que, ao mesmo tempo que é extremamente educativa e incentiva a inteligência coletiva e conectiva, promove a sensação lúdica de superar desafios e conquistar alvos em um prazer produtivo.

\subsection{4 - Conclusão}

\section{Peculiaridades}

A peculiaridade do Blender reside no fato de que, no mesmo software, existem poderosos recursos de modelagem, animação, renderização e engenharia de game. Normalmente os softwares de produção tridimensional estão segmentados nessas diferentes categorias e enfocam a plataforma em um processo, ou dois. Por 
exemplo, o 3D Studio Max, um dos softwares mais populares no mercado da produção tridimensional, é extremamente amigável para modelar objetos inorgânicos e renderizar, enquanto o Maya, também extremamente popular, evidencia a modelagem orgânica e a animação. Ao mesmo tempo, engenharias de game (game engine) não têm recursos refinados de modelagem, sendo necessário importar malhas e modelos de outros softwares.

A característica mais notável do Blender, portanto, é a integração entre modelagem, animação e engenharia de game que, de forma praticamente exclusiva, permite ao usuário desenvolver rapidamente um jogo simples, como foi o caso do game "PacMim", desenvolvido experimentalmente para essa dissertação.

\section{Percepções do software}

No caso da experimentação do Blender para produzir o jogo "PacMim", foram necessárias algumas horas de preparação em termos de incorporar técnicas, conceitos e soluções durante o planejamento do jogo. Além disso, vários tutoriais, manuais, vídeo-aulas e artigos foram consultados e, de forma notável, foram encontradas inúmeras publicações on-line que auxiliaram na produção do game. Além disso, houve a consulta em diversos fóruns e blogs de usuários de Blender que se mostraram bastante solícitos e prontos em ajudar resolvendo dúvidas e auxiliando em questões específicas. Vários arquivos .blend, o formato específico para Blender, estão disponibilizados na internet e com a liberdade de abri-los, alterá-los e testá-los, auxiliam para resolver questões e incorporar soluções.

Além disso, a experiência de poder montar um jogo do início até o fim, por mais simples que seja, surpreende pela satisfação alcançada e por todo o conhecimento assimilado durante o processo. É a clara noção de tecno-pedagogia acontecendo no momento em que ludicidade e assimilação informativa no emprego tecnológico se unem para a formação do ser digital. 


\section{CONSIDERAÇÕES FINAIS}

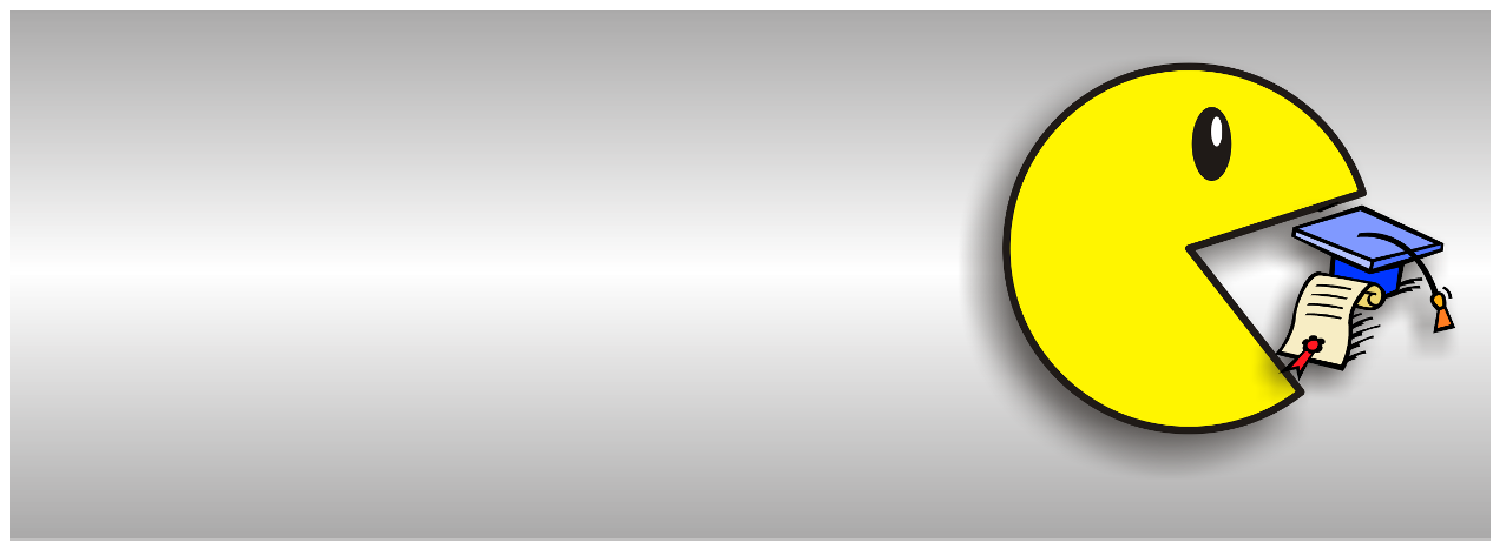




\section{Considerações finais}

Esta dissertação apresenta vários pontos que, não tão conclusivos, são argumentos de partida para novas investigações e aprofundamento. Tais considerações finais podem ser divididas em pelo menos três partes que se conectam em "hiperlink" e, por isso mesmo, são colocadas aqui em ordem diferente da apresentada na formatação dos capítulos.

Primeiramente discorre da percepção dos videogames como expoente da ludicidade digital onde os elementos de interação entre homem e tecnologia se evidenciam a partir do próprio desenvolvimento desse universo. Apontam-se, também, as potencialidades dos games na participação da formação pedagógica e informativa dos usuários, ressaltando os argumentos verificados na análise a partir dos games.

É possível compreender a inevitabilidade da influência dos games e, mais genericamente, das tecnologias digitais de comunicação estudando, no campo filosófico, a ontologia do homem em sua relação intrínseca com a tecnologia. Contextualizando o diálogo homem-tecnologia para a contemporaneidade digital, faz-se referência aos nativos digitais.

Por fim, apresenta-se o conceito que nasce e se desenvolve nesta dissertação e que, de certa forma e, ao mesmo tempo, a conduz e formata. Isso porque, agora nas considerações finais, se constata que a tecno-pedagogia se conforma como o conceito que permite a interação com os demais e que se propõe como inovação dentro do discurso interdisciplinar da comunicação digital.

\section{A partir dos games}

No capítulo 3 foi possível contextualizar o desenvolvimento do universo dos games na sua importância econômica e, sobretudo, na perspectiva da interação entre homem e tecnologia a partir do elemento lúdico. É interessante notar o ciclo histórico que parte das demandas militares por tecnologia computacional e que permitiu o surgimento das primeiras máquinas capazes de calcular os primeiros códigos voltados para o entretenimento eletrônico. Iniciou-se, então, a corrida mercadológica dos videogames que impulsionou o desenvolvimento da computação 
gráfica e lógica a fim de oferecer produtos lúdicos mais atrativos. Tal desenvolvimento, atualmente, implica em simulações extremamente realistas que são utilizadas nos centros de treinamento militar. Esse ciclo também é evidente na computação de lógicas físicas e de inteligência artificial onde os produtos lúdicos e pesquisas científicas acabam se auxiliando no seu desenvolvimento.

É notável, também, como as diferentes gerações dos videogames estabeleceram novas formas de interação e participação ativa dos jogadores. Se nos primórdios dos jogos a interação se baseava em imagens e sons do aparelho televisivo e de um controle por alavanca, hoje se detecta o uso integral do corpo para comandar ações de avatares e uso de óculos tridimensionais.

Outro ponto a ser considerado são as comunidades que se formam por conta do interesse em comum por algum título ou gênero de jogo. Mais do que isso, é importante salientar o quanto os próprios jogos possibilitam a formação de comunidades dentro das suas plataformas de multiusuários online promovendo a socialização em uma verdadeira "brincadeira de (info-)rua".

Além da contextualização histórica dessa relação lúdica entre homem e tecnologia, a dissertação apresentou, no capítulo 4, a experiência analítica de casos de games, ponderando sobre os pontos de intersecção que ressaltam a formação do homem pela tecnologia lúdica que ele mesmo desenvolve. Para tanto, foram selecionados jogos que não têm necessariamente a classificação de "educacional", mas que, até mesmo pelo sucesso comercial, surpreenderam pelas várias abordagens educativas que apresentam.

O jogo Brain Age, por exemplo, traz a proposta de aprimorar o funcionamento cerebral do jogador por meio de exercícios diários e avaliação de desempenho. Ao final, o jogo, acaba incentivando a otimização da capacidade de cálculos matemáticos, leitura, associação cognitiva e reflexo.

Em uma proposta menos educacional, o jogo Spore explora o conceito da evolução natural de espécies e criaturas trazendo a discussão do desenvolvimento social de tribos e impérios até a exploração espacial e as relações interculturais. $O$ ponto principal do jogo está na questão das possibilidades evolutivas que se abrem por uma decisão tomada.

O jogo Ragnarök Online traz a clara prova da socialização que ocorre por meio dos jogos multiplayer online onde vários jogadores se congregam através de seus avatares em uma plataforma que exige a atuação coletiva. Cada jogador tem à 
frente um vasto campo de jogo pois, sem estar preso a objetivos pré-definidos, pode decidir o seu rumo potencializando-o através de ações em conjunto com outros jogadores.

O jogo Cozinheiro das Almas é exemplo evidente da natureza interdisciplinar da comunicação digital que, no caso, desenvolvido em plataforma de game, congrega o ambiente acadêmico e os saberes profissionais de várias áreas de conhecimento (design, arte, história, computação, programação, engenharia, etc.). É notável como a história das belas artes pode ser contextualizada na narrativa e interface dos videogames.

E, por fim, o Blender, como software aberto e polivalente (voltado para modelagem, animação, texturização, renderização, física real e engenharia de game) instiga o usuário a se aprofundar em sua utilização. Na realização de um jogo completo, o Blender possibilita uma experiência lúdica de aprimoramento em termos de modelagem e construção de blocos de códigos lógicos, dentro do contexto da cultura hacker de buscar as soluções com outros usuários mais experientes através de comunidades digitais.

Tais experiências de jogo, tendo como pressuposto metodológico a participação do insider na pesquisa, ou seja, o envolvimento total do pesquisador com o seu objeto de pesquisa, permitiram compreender as novas gerações de nativos digitais.

\section{Nativos digitais}

O capítulo 1 dá os indícios teóricos, filosóficos e ontológicos de quem seriam os nativos digitais, pois trata da relação dialógica entre homem e tecnologia e, depois, do contexto contemporâneo digital abordando os principais aspectos que tangem a sociedade digital.

Para tanto, a partir de Heidegger, a dissertação adota o partido onde a existência do ser só pode ser compreendida como o constante devir e fazer dentro de um contexto ecossistêmico do sujeito homem com o ambiente físico, tecnológico e informativo.

A concepção de Galimberti sobre a inerência da técnica na existência do homem, desde a sua sobrevivência até a sua formação intelectual, cultural e social, reforça o olhar não instrumental da relação entre o homem e a tecnologia. O homem 
só existe enquanto envolvido por um contexto técnico, ou seja, aquilo (tecnologia) que cria e desenvolve é, também, o que permite a sua existência e formação. Da mesma forma, McLuhan apresenta a base de uma concepção dialógica onde o homem só o é quando potencializado pelas tecnologias comunicativas.

Essa afirmação conceitual fica evidente no contexto digital da existência, permanência, atualização e atuação no ciberespaço, termo introduzido por Lévy e ressaltado por Santaella. A análise do ciberespaço, seus impactos e a formação do ser digital, ou nativo digital, é desenvolvida a partir dos discursos teóricos de De Kerckhove, Castells, Prado e Di Felice, entre outros.

Dessa forma, os nativos digitais denotam aqueles que existem enquanto, conectados através das tecnologias digitais, trocam informações e estabelecem pontes sociais, ressignificando o seu habitar através das interfaces digitais. As novas gerações de conectados, os de fato "nativos digitais", são aqueles que geralmente perguntam às outras gerações anteriores (os imigrantes digitais"): "como vocês viviam sem o Google?"

A compreensão da formação do nativo digital se dá através do conceito da tecno-pedagogia.

\section{Tecno-pedagogia}

No capítulo 2 ressaltam-se os aspectos lúdicos na formação do homem. Partindo do teatro grego, onde o elemento lúdico dava bases para o repasse dos valores cívicos da polis. O capítulo desenvolve um diálogo entre as colocações de Huizinga e McLuhan sobre o elemento lúdico na essência humana. A partir de então, vários autores contribuem para fazer a relação entre ensino e aprendizagem através do aspecto lúdico, com bases pedagógicas consolidadas.

Todo o desenvolvimento teórico da dissertação, com o aporte da análise de casos, parece sustentar a afirmativa de que o elemento lúdico e o ambiente tecnológico estão inexoravelmente ligados à formação e a existência do homem.

E todos esses conceitos culminam no termo "tecno-pedagogia" elaborado a partir do encontro presencial com De Kerckhove, que introduziu o termo-chave "tecno-psicologia", e da própria "brincadeira" que a pesquisa propôs ao explorar ludicamente as raízes e despontamentos etimológicos de várias palavras, começando pela pedagogia. 
A tecno-pedagogia pode ser observada nas várias iniciativas escolares de digitalização de conteúdo e nas didáticas digitais que, como bem aponta Negroponte, potencializam o aprendizado e a assimilação de conteúdos informativos através do elemento lúdico. A tecno-pedagogia também é evidenciada pela cultura hacker, onde o lúdico faz parte natural das ações e do processo de formação dessa "tribo" de nativos digitais.

Tecno-pedagogia abarca, portanto, a idéia de que a formação do homem é inerentemente tecnológica e lúdica e que a resultante da relação dialógica entre homem e tecnologia tem naturalmente o elemento lúdico. 


\section{BIBLIOGRAFIA}

ABRUZZESE, Alberto. O esplendor da TV: origem e destino da linguagem audiovisual. São Paulo: Studio Nobel, 2006.

AMARAL, Maria Nazaré de Camargo Pacheco. Dewey: jogo e filosofia da experiência democrática. In KISHIMOTO, Tizuko Morchida (org.). $\mathbf{O}$ brincar e suas teorias. São Paulo: Thomson Learning, 2002, pp. 79 -107.

BARROS, Laan Mendes de. Comunicação e Educação numa Perspectiva Plural e Dialética. In Nexos - Revista de Estudos de Comunicação e Educação. São Paulo, Ano I, no. I, 2ํㅗsemestre 1997.

BENJAMIN, Walter. A Modernidade e os modernos. Rio de Janeiro: Tempo Brasileiro, 1975.

34, 2002 .

Reflexões sobre a criança, o brinquedo e a educação. São Paulo: Ed.

BORGMAN, Christine L. From Gutenberg to the global information infrastructure: acess to information in the networked world. Cambrigde: MIT Press, 2000.

BRANDÃO, Junito de Souza. Teatro grego: origem e evolução. São Paulo: Ars Poética, 1992.

BRIGGS, Asa; BURKE, Peter. Uma história social da mídia: de Gutenberg à internet. Rio de Janeiro: Jorge Zahar Ed., 2004.

CAMBI, Franco. História da Pedagogia. São Paulo: Fundação Editora da UNESP (FEU), 1999.

CASTELLS, Manuel. Globalización, tecnologia, trabajo, empleo y empresa. In http://www.Ifactoriaweb.com/articulos/castells7.htm, 1998. Consultado em 06/10/2005.

A Sociedade em rede. São Paulo: Paz e Terra, 1999.

A galáxia da internet: reflexões sobre a internet, os negócios e a sociedade. Rio de Janeiro: Jorge Zahar, 2003.

CAILLOIS, Roger. Os jogos e os homens. Lisboa: Cotovia, 1990.

CASTORINA, José Antonio et alii. Piaget, Vygotsky: novas contribuições para o debate. 5ª.ed., São Paulo: Ática, 1998.

CHATEAU, J. O jogo e a criança. São Paulo: Summus, 1987.

CITELLI, Adilson Odair. Comunicação e educação: a linguagem em movimento. São Paulo:SENAC São Paulo, 2000. 
CRANDALL, R. \& SIDAK, G.. Video games: Serious Business for America's Economy. EUA: ESA - Entertainment Software Association, 2006.

COUTINHO DE LIMA, Marcelo Oliveira. A sociedade da informação e a world wide web: uma análise comparativa de nove países. 2002. 170p. Tese de Doutorado - FFLCH da USP, São Paulo.

CUNHA, Antônio Geraldo da. Dicionário etimológico da língua portuguesa. Rio de Janeiro: Lexikon, 2007.

DE KERCHKHOVE, Derrick De. A pele da cultura. Lisboa, Portugal: Relógio D’Água, 1997. House, 1997.

Connected intelligence: The Arrival of the Web Society. EUA: Somerville

DI FELICE, Massimo. "Das tecnologias da democracia para as tecnologias da colaboração" in DI FELICE, Massimo (org.). Do público para as redes: a comunicação digital e as novas formas de participação social. São Caetano do Sul, SP: Difusão Editora, 2008.

DIAS, Marina Célia Moraes. "Metáfora e pensamento: considerações sobre a importância do jogo na aquisição do conhecimento e implicações para a educação pré-escolar" in: KISHIMOTO, Tizuko M. (org.). Jogo, brinquedo, brincadeira e a educação. São Paulo: Cortez, 2001.

ECO, Umberto. Apocalípticos e integrados. São Paulo: Perspectiva, 2006.

EGENFELDT-NIELSEN, Simon \& SMITH, Jonas H. \& TOSCA, Susana P. Understanding video games: the essential introduction. New York: Routledge, 2008.

ENTERTAINMENT SOFTWARE ASSOCIATION. Essential facts about the computer and video game industry. 2008

ENTERTAINMENT SOFTWARE ASSOCIATION. Video games: serious business for America's economy. 2006.

FERRÉS, Joan. Televisão e educação. Porto Alegre: Artes Médicas, 1996.

GALIMBERTI, Umberto. Psiche e techne: o homem na idade da técnica.São Paulo: Paulus, 2006.

HEIDEGGER, Martin. Ensaios e conferências. Petrópolis, RJ: Vozes, 2001.

HIMANEN, Pekka. A ética dos hackers e o espírito da era da informação: a importância dos exploradores da era digital. Rio de Janeiro, Campus, 2001.

HUIZINGA, Johan. Homo ludens. São Paulo: Perspectiva, 2007. 5ª Ed.

IDSA - Interactive Digital Software Association. Economic impact of the demand for playing interactive entertainment software. EUA: IDSA, 2001. 
State of the industry report 2000-2001. EUA: IDSA, 2001.

KISHIMOTO, Tizuko M. "O jogo e a educação" in: KISHIMOTO, Tizuko M. (org.). Jogo, brinquedo, brincadeira e a educação. São Paulo: Cortez, 2001.

. "Froebel e a concepção de jogo infantil" in: KISHIMOTO, Tizuko M. (org.).

O brincar e suas teorias. São Paulo: Thomson Learning, 2002.

LANNES, Osmar Perazzo. Teatro grego. São Paulo: Ed. Paumape, 1993.

LAUREL, Brenda. The art of human-computer interface design. New York: Addison-Wesley, 1990.

LEÃO, Lúcia. O chip e o caleidoscópio: reflexões sobre as novas mídias. São Paulo: Ed. Senac, 2005.

LEMOS, André. Cibercultura: tecnologia e vida social na cultura contemporânea. Porto Alegre: Sulinas, 2002.

realismo

O imaginário da cibercultura: entre o neo-ludismo, tecno-utopia, tecno(www.facom.ufba.br/ciberpesquisa/andrelemos/imaginario.htm) tecno-surelaismo.

LÉVY, Pierre. As tecnologias da inteligência: o futuro do pensamento na era da informática.Tradução Carlos Irineu da Costa. Rio de Janeiro: Ed. 34, 1993.

. Cibercultura. São Paulo: Ed. 34, 1999.

LITTO, Frederick M. Um modelo para prioridades educacionais numa sociedade de informação. Revista Patio: Revista Pedagógica, Porto Alegre, v. 1, n. 3, p. 14-21, 1998.

- Campus Computing Report.Br 2004: Computação e Tecnologia da Informação nas Instituições de Ensino Superior no Brasil. São Paulo: Altana, 2005. v. 1.

A nova ecologia do conhecimento: conteudo aberto, aprendizagem e desenvolvimento. Inclusão Social, v. 01, p. 73-78, 2006.

MACLUHAN, Marshall. Os meios de comunicação como extensões do homem. São Paulo: Cultrix , 1964.

MARCHETTI, Marcos Paulo. Diálogos à distância: cultura digital e espaços de habitar. Dissertação de Mestrado. São Carlos: EESC-USP/Nomads.usp, 2004.

MARTIN-BARBERO, Jesús. Desafios culturais da comunicação à educação. In Revista Comunicação \& Educação. São Paulo: CCA-ECA-USP/Segmento, Ano VI, n.18, maio/set. 2000. pp. 51-61.

. Dos meios às mediações: comunicação, cultura e hegemonia. 2. ed., Rio de Janeiro: Editora UFRJ, 2003. 
MEGUERDICHIAN, Alan. É o estudante quem deve determinar o caminho para o conhecimento. Portal Aprendiz, 2007, http://aprendiz.uol.com.br/ content/breshetere.mmp (acesso em 20 de janeiro de 2009)

MITCHELL, William. J. City of bits. Cambridge, Mass.: MIT Press, 1999.

Press, 2003.

. ME++ : The cyborg self and the networked city. Cambridge, Mass.: MIT

. J. The logic of architecture: design, computation, and cognition. Cambridge, Mass.: MIT Press, 1990.

MORIN, Edgar. Os sete saberes necessários à educação do futuro. 2. ed. São Paulo: Cortez; Brasília, DF: UNESCO, 2000.

. Pensamento e linguagem. 2.ed., São Paulo: Martins Fontes, 1998.

MOYLES, Janet R. Só brincar? O papel do brincar na educação infantil. Porto Alegre: Artmed, 2002.

NEGROPONTE, Nicholas. A vida digital. São Paulo: Cia das Letras, 1995.

OLIVEIRA, Marta Kohl de. Vygotsky - aprendizado e desenvolvimento: um processo sócio-histórico. São Paulo: Scipione, 1995.

PEREIRA, Vinícius Andrade. Marshall McLuhan, o conceito de determinismo tecnológico e os estudos dos meios de comunicação contemporâneos. Razón y Palabra, v. 52, 2006.

Reflexões sobre as materialidades dos meios: embodiment, afetividade e sensorialidade nas dinâmicas de comunicação das novas mídias. Revista Fronteira (UNISINOS), v. VIII, p. 93-101, 2006.

. Consciência e memória como objetos da Comunicação: o approach de Marshall McLuhan.. Revista FAMECOS, Porto Alegre, v. 24/07, p. 149-157, 2004.

As tecnologias de comunicação como gramáticas: meio, conteúdo e mensagem na obra de M. McLuhan.. Contracampo (UFF), Niteroi - RJ, v. 10/11, p. 07-20, 2004.

Ciberespaço: Um passo da dança semiótica do Universo. Contracampo (UFF), Niterói - RJ, v. 4, p. 159-181, 2000.

(org.). Cultura digital trash: Linguagens, Comportamentos, Entretenimento e Consumo. 1. ed. Rio de Janeiro: e-papers, 2007. v. 1. 175 p.

PERNIOLA, Mario. O sex appeal do inorgânico. São Paulo: Studio Nobel, 2005.

PIAJET, Jeans \& INHELDER, Bärbel. A psicologia da criança. 10ª ed., Rio de Janeiro: Bertrand, 1989. 
PIAJET, Jean. A inguagem e o pensamento da criança. 5a. ed., São Paulo: Martins Fontes, 1989.

. A formação do símbolo na criança. Rio de Janeiro: LTC, 1990.

. O juízo moral na criança. São Paulo: Summus, 1994.

. A construção do real na criança. São Paulo: Ática, 2002.

PRADO, Gilberto. Arte telemática: dos intercâmbios pontuais aos ambientes virtuais multiusuários. São Paulo: Itaú Cultural, 2003.

PRICEWATERHOUSECOOPERS International Limited. Global entertainment and media outlook: 2008-2012. 2008

REGO, Teresa Cristina. Vygotsky: uma perspectiva histórico-cultural da educação. $7^{a}$.ed., Petrópolis: Vozes, 1999.

SALEN, K. \& ZIMMERMAN, E. Rules of play: game design fundamentals. Londres: The MIT Press, 2004.

SANTAELLA, Lúcia. Culturas e artes do pós-humano: da cultura das mídias à cibercultura. São Paulo: Paulus, 2003. Paulus, 2004.

Navegar no ciberespaço: O perfil cognitivo do leitor imersivo. São Paulo:

SANTOS, Laymert Garcia dos. Politizar as novas tecnologias. São Paulo: Ed. 34, 2001.

SILVA, L. A. Simulacron: Professional game \& level design. Curitiba: Free Editora, 2004.

SILVEIRA, Sérgio Amadeu. Software livre: a luta pela liberdade do conhecimento. São Paulo: Editora Perseu Abramo, 2004.

SINGER, Dorothy G. \& SINGER, Jerome L. Imaginação e jogos na era eletrônica. Porto Alegre: Ed. Artmed-Bookman, 2007.

SOARES, Ismar de Oliveira. Sociedade da Informação ou da comunicação. São Paulo: Cidade Nova, 1997.

. Educomunicação: um campo de mediações. In Revista Comunicação \& Educação. São Paulo: CCA-ECA-USP/Segmento, Ano VII, n. 19., 2000.

STROOP, Jr. Studies of interference in serial verbal reactions. Journal of Experimental Psychology, 18: 643-62, 1935.

TOFFLER, Alvin. A terceira onda. São Paulo: Record, 1995.

VIANA, Claudemir. O lúdico e a aprendizagem na cibercultura: jogos digitais e Internet no cotidiano infantil. 2005. p. 275. Tese de Doutorado - Escola de Comunicações e Artes da USP, São Paulo. 
VIRILLIO, Paul. A bomba informática. São Paulo: Estação Liberdade, 2000.

VITÓRIA, M. I. C. "O brinquedo e a brincaderia: uma relação marcada pelas práticas sociais" in: JACOBY, $S$ (org.) A criança e a produção cultural. Porto Alegre: Mercado Aberto, 2003.

Vygotsky, Liev S. A formação social da mente. 3ª . ed., São Paulo: Martins Fontes, 1989.

WARDRIP-FRUIN, N.; MONTFORT, N. (org.). The new media reader. Cambridge: The MIT Press, 2003.

WIENER, Norbert. Cibernética e sociedade: uso humano dos seres humanos. São Paulo: Editora Cultrix, 1950.

\section{Sites consultados:}

http://www.retrofollie.com/2008/07/tennis-for-two.html (em 23/dez/2008)

http://aprendiz.uol.com.br/content/breshetere.mmp (em 20/jan/2009)

http://arstechnica.com/news.ars/post/20080618-gaming-expected-to-be-a-68-billionbusiness-by-2012.html (em 02/jan/2009)

http://blog.computerwoche.de/wp-content/uploads/tentacle.png (em 02/jan/2009)

http://bopecs.blogspot.com/ (em 02/jan/2009)

http://emotiv.com/ (em 02/jan/2009)

http://games.levelupgames.uol.com.br/ragnarok/ (em 25/abr/2009)

http://kotaku.com/255419/ps3-hd-eye-toy-card-game-dated (em 02/jan/2009)

http://lastshepard.wordpress.com/2008/05/12/wii-sports/ (em 29/dez/2008)

http://nintendo-wii.tudosobre.info/nintendo-wii-finalmente-entra-na-onda-saudavelem-uma-academia/ (em 29/dez/2008)

http://outerspace.ig.com.br/retrospace/ (em 23/dez/2008)

http://outerspace.ig.com.br/retrospace/ (em 29/dez/2008)

http://pt.wikipedia.org/wiki/Ficheiro:Oscilloscope.jpg (em 23/dez/2008)

http://pt.wikipedia.org/wiki/Game_Boy_Advance (em 29/dez/2008)

http://pt.wikipedia.org/wiki/História_dos_videogames (em 23/dez/2008)

http://pt.wikipedia.org/wiki/Nintendo_GameCube (em 29/dez/2008) 
http://pt.wikipedia.org/wiki/PlayStation_2 (em 29/dez/2008)

http://pt.wikipedia.org/wiki/Playstation_3 (em 29/dez/2008)

http://pt.wikipedia.org/wiki/PlayStation_Portable (em 29/dez/2008)

http://pt.wikipedia.org/wiki/Wii (em 29/dez/2008)

http://pt.wikipedia.org/wiki/Xbox (em 29/dez/2008)

http://pt.wikipedia.org/wiki/Xbox_360 (em 29/dez/2008)

http://ui24.gamefaqs.com/1399/gfs_5996_2_118.jpg (em 02/jan/2009)

http://willyland.wordpress.com/category/wii/ (em 29/dez/2008)

http://www.blender.org/ (em 08/jan/2009)

http://www.brainage.com

http://www.cap.eca.usp.br/poeticas/?page_id=28 (em 08/jan/2009)

http://www.daylife.com/photo/04xe0WSbBN6XT (em 02/jan/2009)

http://www.delirus.com.br/extras/infografico_cursos_game.jpg (em 06/jan/2009)

http://www.edimensional.com/ (em 02/jan/2009)

http://www.flickr.com/photos/ilovejackdaniels/396262495/sizes/o/

(em 02/jan/2009)

http://www.gameconsoles.com/images/Nintendo_20DS_20CONSOLE.jpg;

(em 29/dez/2008)

http://www.gamefaqs.com (em 06/jan/2009)

http://www.gamefaqs.com/computer/doswin/image/949627.html (em 08/jan/2009)

http://www.gamefaqs.com/console/ps3/ (em 29/dez/2008)

http://www.gamefaqs.com/console/psp/ (em 29/dez/2008)

http://www.gamefaqs.com/console/wii/ (em 29/dez/2008)

http://www.gamefaqs.com/console/xbox360/ (em 29/dez/2008)

http://www.gamefaqs.com/portable/ds/ (em 29/dez/2008)

http://www.gamefaqs.com/portable/gbadvance/ (em 29/dez/2008)

http://www.gamespot.com/ds/puzzle/brainagetrainyourbraininminutesaday/ (em 02/mar/2009) 
http://www.gamespot.com/ps2/ (em 29/dez/2008)

http://www.gamespot.com/ps2/ (em 29/dez/2008)

http://www.gametab.com/ds/brain.age.train.your.brain.in.minutes.a.day/5245/ (em 08/jan/2009)

http://www.ragnarok.com (original)

http://www.reuters.com/article/technologyNews/idUSN1840038320080618 (em 02/jan/2009)

http://www.spore.com.br/

http://www.the-nextlevel.com/features/eye_toy/eye-toy.shtml (em 29/dez/2008)

http://www.ubergizmo.com/15/archives/2007/03/emotiv_the_brain_computer_interfac e_technology.html (em 02/jan/2009)

http://www.ubergizmo.com/15/archives/2007/10/nintendo_wii_helps_stroke_victims_r ecover.html (em 29/dez/2008)

http://www.unidev.com.br (em 06/jan/2009)

http://www.youtube.com/watch?v=Bjro-alWelg (em 02/mar/2009) 